Artur Pantoja Marques

\title{
Proposta de um Programa de Gestão da Qualidade para uma Empresa Genérica de Posicionamentos com GPS
}

Tese apresentada à Escola de Engenharia de São Carlos da Universidade de São Paulo, como parte dos requisitos para obtenção do Título de Doutor em Engenharia de Transportes.

Orientador: Prof. Dr. Irineu da Silva 
Ao meu pai Rodoval Coentro Marques (in memorian)

...que tudo fez por mim e,

hoje povoa minhas mais alegres lembranças.

\section{A minha família:}

àquela que um dia deixei...

... parte integrante na formação do meu caráter, moral e crença.

... que com doçura ensinou-me a sorrir,

que com amor ensinou-me a viver, $e$, com perfeição ensinou-me a amar.

meu pai, minha mãe Cenira Pantoja Marques, e meus irmãos Júlia, Ana Lúcia, Albério, Aldenira e Juliana.

e aquela que tenho construído...

... que está constantemente ao meu lado apoiando-me com carinho, e compartilha comigo todas as vitórias, frustrações e alegrias.

minha esposa Claudia e nossa filha Paulinha. 


\section{AGRADECIMENTOS}

A Deus.

A minha esposa Claudia e a minha filha Paula pelo apoio e compreensão nos momentos difíceis durante todo o desenvolvimento desta tese que, pacientemente, muitas vezes, abriram mão do convívio comigo para dar espaço às pesquisas e leituras, e sempre acreditaram que o resultado conquistado compensaria todos os esforços.

Ao Prof. Dr. Irineu da Silva pelo apoio, orientação e confiança depositada em mim para desenvolver esta pesquisa.

Ao Prof. Dr. Toledo pelas sugestões para a melhoria deste trabalho.

A Universidade Estadual Paulista UNESP pelo apoio e o Departamento de Engenharia Civil da Faculdade de Engenharia de Ilha Solteira, pelo afastamento concedido para desenvolver a pesquisa.

Aos amigos João Olympio e Paulo Sérgio pela ajuda indispensável para a realização desta tese.

A Professora Waded Antonio pela correção do texto.

A todas as pessoas que direta ou indiretamente contribuíram para a realização desta pesquisa 


\section{RESUMO}

MARQUES, A. P. (2006). Proposta de um Programa de Gestão da Qualidade para uma Empresa Genérica de Posicionamentos com GPS. (Tese) - Escola de Engenharia de São Carlos, Universidade de São Paulo, São Carlos, 2006.

Este trabalho trata da proposta de um Sistema de Gestão da Qualidade para uma empresa genérica prestadora de serviços de posicionamento com o GPS, como alternativa para melhorar a gestão da organização e garantir a Qualidade de seus serviços e produtos. O aumento da demanda por esse tipo de serviço estimulou o aparecimento de novas empresas específicas em GPS e adaptação de antigas para atender um mercado crescente e cada vez mais exigente. Por se tratar de um processo novo, sua implantação requer mudanças significativas tanto de ordem técnica (intimamente ligadas ao conhecimento específico do sistema e suas capacidades) como administrativa (meios e políticas que possam garantir uma gestão efetiva de todos os processos envolvidos no posicionamento com o GPS dentro da empresa). A modernização imposta ao setor de topografia e geodésia em seu cenário produtivo e econômico, com o aparecimento de novas técnicas produtivas e ferramentas gerenciais, não pode mais ser protelada. Isso impõe às organizações uma necessidade emergencial de mudança e grandes desafios, entre eles o de sua própria sobrevivência. A execução de um serviço de posicionamento com o sistema GPS consiste em uma seqüência de procedimentos práticos que, se forem bem executados, proporcionarão maior probabilidade de êxito ao resultado final. Os procedimentos dependem muito de cada caso, e normalmente são definidos por indicações dos fabricantes dos instrumentos, normas e especificações oficiais e, na grande maioria das vezes, pela própria experiência prática do responsável. Como parte desse trabalho foi desenvolvida uma pesquisa social para identificar como são e como agem as empresas que prestam serviços de posicionamento com o sistema GPS no Brasil. Com base nos resultados dessa pesquisa, elaborou-se uma empresa genérica de posicionamento com GPS, com características similares à maioria, e que serviu como referência na concepção dos padrões para os processos básicos da empresa. O modelo de Gestão da Qualidade proposto teve como guia o Sistema da Qualidade preconizado pela ISO série 9000. Consideraram-se também as ferramentas de Gestão e Controle da Qualidade comumente aplicados na indústria de manufatura e adaptados aos serviços de um posicionamento com GPS. O resultado apresenta uma seqüência de implantação do modelo com as devidas recomendações e viabilidades. Para ilustrar, são apresentados os resultados benéficos obtidos com a aplicação direta dos padrões técnicos da empresa genérica, em um posicionamento real para pontos estáticos, em que se considerou apenas a parte produtiva. O resultado mostrou-se bastante convincente.

Palavras-chave: serviços com GPS; empresa de posicionamento com GPS; modelo de Gestão da Qualidade. 


\section{ABSTRACT}

MARQUES, A. P. (2006). Suggestion of a Program the Quality Management for a Generic Company of GPS surveying. (D.Sc) - Escola de Engenharia de São Carlos, Universidade de São Paulo, São Carlos, 2006.

This thesis deals with a proposal for Quality Management for a generic GPS Surveying Company as an alternative to management and service quality improvement. As a result of the GPS measurement demand increasing, an important number of new companies and/or renovated ones have been established in order to operate in that market. But considering that it is a new process some changes must be performed in order to accommodate the old surveying techniques and the old fashioned management to the new reality. This implies in a new management organization which must be based on a well described procedure sequence aiming a final quality control success. As an important part of that research a social research has been applied to several Brazilian GPS service provider companies with the purpose of knowing the status of the sector related to the quality management. Based on that research a hypothetical company was considered in order to give subsides to the elaboration of a standardized company. The proposed Quality Management Model was based on the ISO 9000 Quality System adopting management tools and quality control operators applied in the general industry adapted to the GPS surveying companies.

This thesis shows the results of that research presenting an implementation model for quality management considering a real surveying GPS work based on the new GPS measurement techniques.

Keywords: services with GPS; positioning company with GPS; model of Quality Management. 


\section{LISTA DE FIGURAS}

Figura 1 - Componentes de um equipamento GPS (Base) c/opção T. Real. 11

Figura 2 - Componentes de um equipamento GPS (Remoto) c/opção T. Real. 12

Figura 3 - Tipos de antenas GPS $\quad 12$

Figura 4 - Posicionamento Absoluto Estático $\quad 15$

Figura 5 - Posicionamento Relativo Estático $\quad 16$

$\begin{array}{lll}\text { Figura } 6 \text { - Posicionamento Relativo Cinemático } & 17\end{array}$

Figura 7 - Pós-processamento dos dados Relativos 18

Figura 8 - $\quad$ DGPS - Correções Via Usuário 19

Figura 9 - DGPS - Correções Via Satélite 20

Figura 10 - DGPS - Correções Via Radiofarol (Beacon) 21

Figura 11 - RTK - Correções Via Estações de Referência 22

Figura 12 - Etapas de um posicionamento genérico com GPS 39

Figura 13 - Métodos de posicionamento com GPS e suas precisões 40

Figura 14 - Aspectos a serem considerados na escolha de um receptor GPS 41

Figura 15 - Conceito de Validação

Figura 16 - Configuração de Rede GPS Radial 45

Figura 17 - Configuração de Rede GPS Convencional 46

Figura 18 - Medição da altura da antena

Figura 19 - Esquema do macroprocesso de posicionamento com GPS 56

Figura 20 - Evolução das Eras da Qualidade $\quad 62$

Figura 21 - Exemplo de como é composto um Sistema da Qualidade. 71

Figura 22 - Documentos da Qualidade $\quad 72$

$\begin{array}{ll}\text { Figura } 23 \text { - Estrutura do Sistema da Qualidade. } & 73\end{array}$

$\begin{array}{ll}\text { Figura } 24 \text { - O Ciclo PDCA } & \mathbf{8 0}\end{array}$

Figura 25 - Informações de entrada de um PGQT 91

Figura 26 - Esquema de implementação do SGQ pela ISO $9000 \quad 94$

Figura 27 - Esquema de elaboração de um processo 96

Figura 28 - Rede típica de processos interativos $\quad 97$

$\begin{array}{lr}\text { Figura } 29 \text { - Padronização de processos } & 99\end{array}$

Figura 30 - Esquema do Modelo de Gestão da Qualidade proposto 101

Figura 31 - Sumário das etapas de 1 a 4 do Modelo de GQ proposto 102 
Figura 32 - Sumário das etapas de 5 a 7 do Modelo de GQ proposto 103

Figura 33 - Modelo básico para procedimentos (Documentação) 108

Figura 34 - Sumário das etapas de 5 a 7 do Modelo de GQ proposto 109

$\begin{array}{ll}\text { Figura } 35 \text { - Gráfico de Organização da empresa GPSAT } & 117\end{array}$

$\begin{array}{lr}\text { Figura } 36 \text { - Planta da empresa GPSAT } & 118\end{array}$

Figura 37 - Macroprocesso LGPS - GPSAT $\quad 119$

Figura 38 - Esquema operacional básico de um posicionamento com GPS 120

Figura 39 - Representação da Unidade Organizacional GPSAT 121

Figura 40 - Relação de Indicadores da Qualidade 122

Figura 41 - Objetivos e metas da Qualidade 123

Figura 42 - Situação das empresas de GPS com relação à GQ. 175

Figura 43 - O que pensam as empresas que ainda não praticam a GQ 175

Figura 44 - Forma de contratação de serviços da empresa 176

$\begin{array}{ll}\text { Figura } 45 \text { - Garantia exigida pelos clientes } & 177\end{array}$

Figura 46 - Assunto que as empresas gostariam de saber mais 177

Figura 47 - Mapa de reconhecimento e implantação 182

Figura 48 - Lista de verificação prévia do reconhecimento e implantação $\quad 184$

Figura 49 - Ponto M01-N - 20km (Folha A) 185

Figura 50 - Ponto M01-S - 20km (Folha B) 185

Figura 51 - Mapa de localização geral das estações do projeto 186

$\begin{array}{ll}\text { Figura } 52 \text { - Programação de campo (Folha1) } & 187\end{array}$

Figura 53 - Programação de campo (Folha2) 188

Figura 54 - Mapa de projeto MGPS-1 (Folha3) 189

Figura 55 - Identificação da Estação M01-N (Folha4) 190

Figura 56 - Identificação da Estação M01-S (Folha5) 191

Figura 57 - Rastreio de Estação $\quad 192$

Figura 58 - Relatório de ocupação M01-N 193

Figura 59 - Relatório de ocupação M01-S 193

Figura 60 - Processamento da seção $01 \quad 195$

Figura 61 - Satélites observados na base de referência 195

Figura 62 - Parâmetros usados no processamento 196

Figura 63 - Triângulo formado pelos vetores entre as estações. 196

Figura 64 - Fechamento do triângulo entre as estações 197 


\section{LISTA DE TABELAS}

Tabela 1 - $\quad$ Classificação das aplicações de posicionamento com GPS $\quad 10$

Tabela 2 - $\quad$ Características das Técnicas de Posicionamento Relativo 22

Tabela 3 - Componentes de um reconhecimento de campo $\quad 43$

Tabela 4 - Tipos de controle e configuração de rede GPS $\quad 45$

Tabela 5 - Responsabilidades de Campo $\quad 54$

Tabela 6 - Resumo das Principais Eras da Qualidade $\quad 63$

Tabela 7 - $\quad$ Pontos fortes e fracos da pequena empresa 69

Tabela 8 - $\quad$ Simbologia usada na elaboração de fluxogramas $\quad 98$

Tabela 9 - $\quad$ Processos das etapas de padronização e delineamento do SQ. $\quad 100$

Tabela 10 - $\quad$ Sugestão de Cronograma para implantação do SGQ. 113

Tabela 11 - Diagnóstico do Ambiente Externo - GPSAT 114

Tabela 12 - Diagnóstico do Ambiente Interno - GPSAT 115

Tabela 13 - Legenda dos macroprocessos: 125

Tabela 14 - Descrição dos mapas de processos $\quad 131$

Tabela 15 - Questionários recebidos por região 174 


\section{LISTA DE SÍMBOLOS}

AAF

ABNT

AETESP

AFNOR

AS

ASQC

C/A-code

CDHU

CONFEA

CREA

CQ

CTS

DGPS

DoD

DOP

EFQM

EQA

FGCC

FGDC

FMEA

GDOP

GLONASS

GNSS

GPS

GQ

HDOP

HD

I/O

IBGE

ICSM
American Air Force - USA

Associação Brasileira de Normas Técnicas

Associação das Empresas de Topografia do Estado de São Paulo

Association Française de Normalisation

Antispoofing

American Society for Quality Control

Coarse/acquisition code (1.023Mhz)

Companhia de Desenvolvimento Habitacional e Urbano de São Paulo

Conselho Federal de Engenharia Arquitetura e Agronomia

Conselho Regional de Engenharia Arquitetura e Agronomia

Controle de Qualidade

Conventional Terrestrial System

Differential GPS

United States Department of Defense

Dilution of Precision

European Foudation for Quality Management

European Quality Award

Federal Geodetic Control Committee - USA

Federal Geographic Data Committee - USA

Failure Modes and Effects Analysis

Geometric dilution of precision

Global'naya Navigatsionnaya Sputnikkovaya Sistema

Global Navigation Sattelite System

Global Positioning System

Garantia de Qualidade

Horizontal dilution of precision

Hard Disk

Input / output

Instituto Brasileiro de Geografia e Estatística

Inter-Governmental Advisory Committee on Surveying and Mapping 
INCRA Instituto Nacional de Colonização e Reforma Agrária

ISO International Standard Organization

JIS Japanese Industrial Standards

JUSE Union of Japanese Scientists and Engineers

L1 L1 carrier (1575,42 Mhz)

L2 L2 carrier (1227,6 Mhz)

L5 L5 carrier (1176,45 Mhz)

LCD Liquid Crystal Display

NAVSTAR Navigation Satellite Timing and Ranging

NBS Nacional Bureal de Serviços

NIMA National Imagery and Mapping Agency

P-code Precision code (10,23 Mhz)

PBQP Programa Brasileiro da Qualidade e Produtividade

PDCA Plan, Do, Check, Action

PDGPS Precise Differential Global Positioning System.

PDOP Positional dilution of precision

PGQT Programa de Gestão da Qualidade Total

PNQ Prêmio Nacional da Qualidade

ppm Partes por milhão

PPS Precise Positioning Service

PRN Pseudorandon Noise

QUALIHAB Programa da Qualidade da Construção Habitacional de São Paulo

RAM Ramdom Access Memory

RF Radio Frequency

RHCP Right-Hand Circularly Polarized

RINEX Receiver independent Exchange Format

RTCM Radio Technical Committee for Maritime Service

RTK Real-time Kinemetic Positioning

SA Selective Availability

SGQ Sistema de Gestão da Qualidade

SIG Sistema de Informação Geográfica

SINEX Solution independent exchange format

SPS Standard Positioning Service 
TDOP Time dilution of precision

TQC Total Quality Control

TQM Total Quality Management

TRANSIT Navy navigation satellite system

UTC Coordinate Universal Time

UERE User Equivalent Range Error

USAF - JPO United States Air Force Joint Program Office

USNO United States Naval Observatory

VDOP Vertical dilution of precision

WADGPS Wide Area Differential GPS

WGS 84 Word Geodetic System of 1984

Y-code Encrypted P-code 


\section{SUMÁRIO}

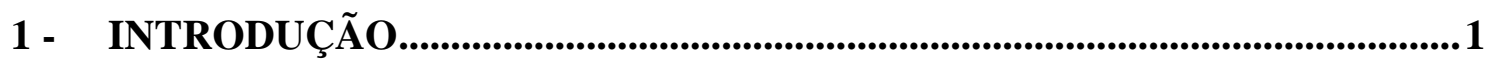

1.1 - Considerações Preliminares........................................................................... 1

1.2 - Delimitação do Problema E Objetivos ..................................................................

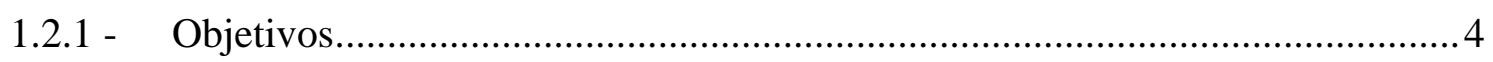

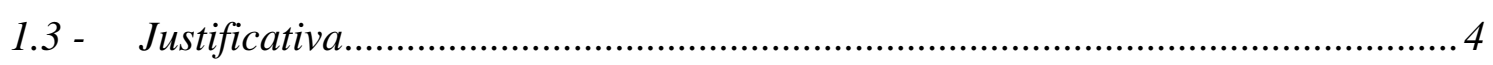

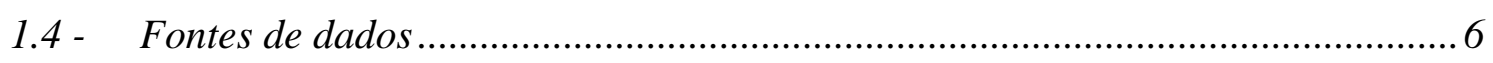

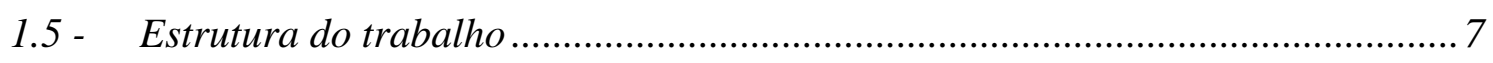

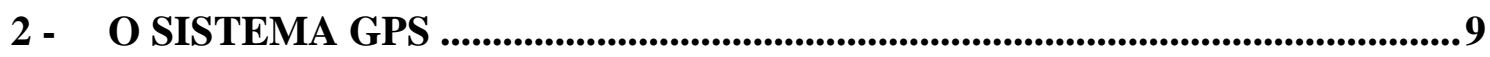

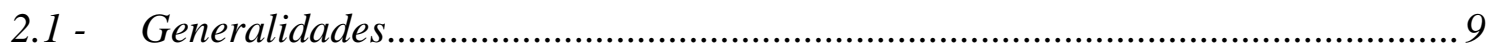

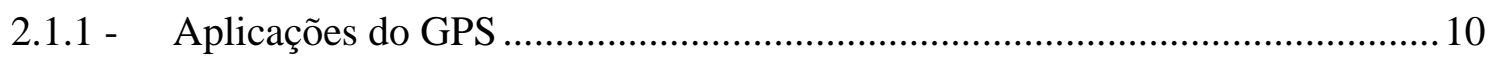

2.1.2 - Composição de um equipamento GPS ......................................................... 11

2.1.3 - Princípio básico de funcionamento do GPS. ................................................ 15

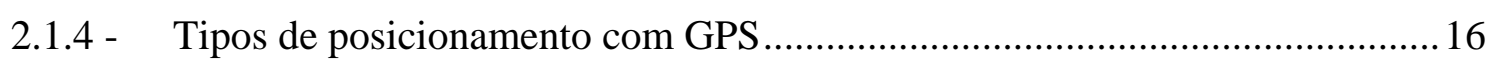

2.1 .5 - Métodos de posicionamento Relativo com GPS .......................................... 17

2.1.6 - Técnicas para obtenção dos resultados com GPS.......................................... 18

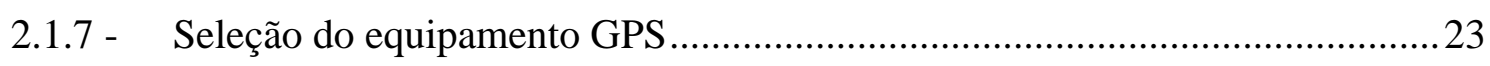

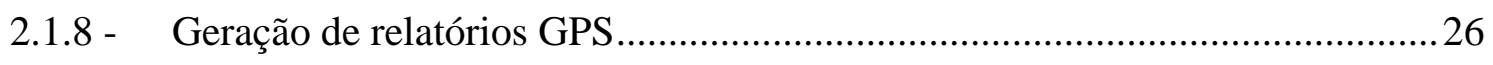

2.2 - Especificações e Normas para GPS ...............................................................28

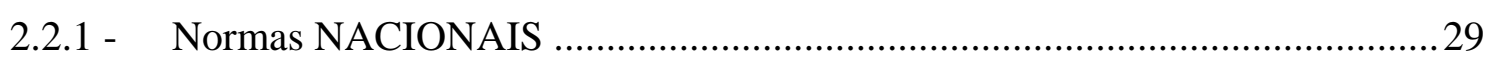

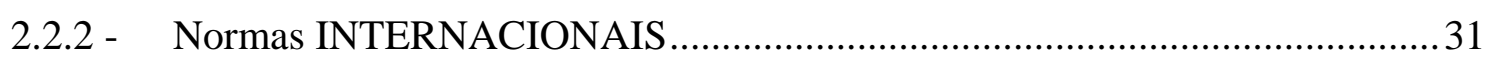

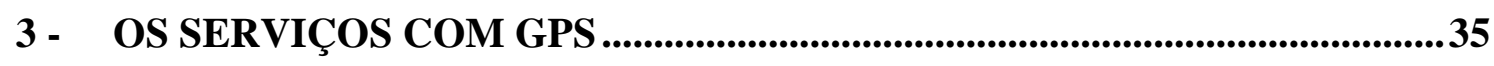

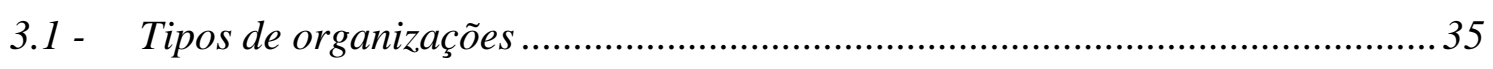

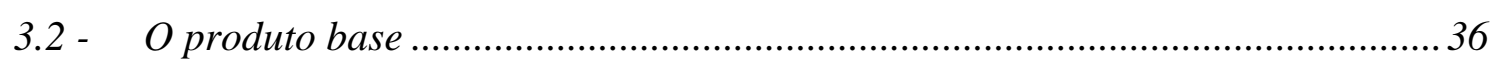

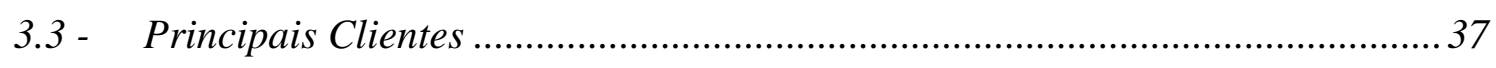

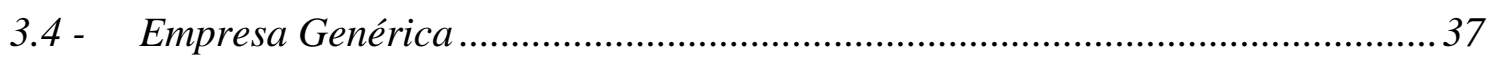

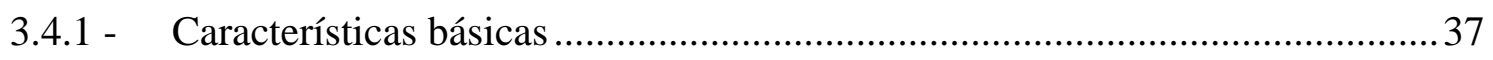

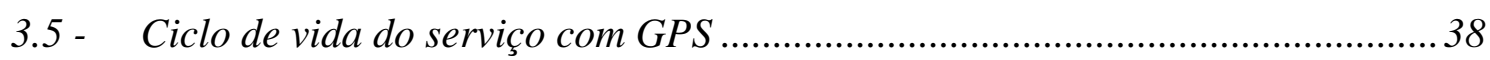




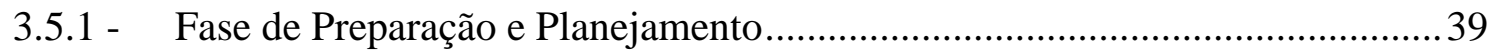

3.5.2 - Fase de Operações de Campo .......................................................................48

3.5.3 - Fase de Processamento dos dados e Relatório final ..........................................54

3.6 - A Gestão Organizacional da Empresa …...........................................................5

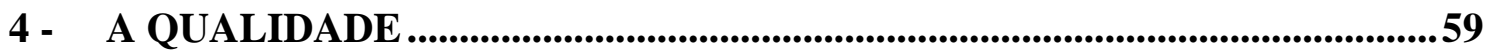

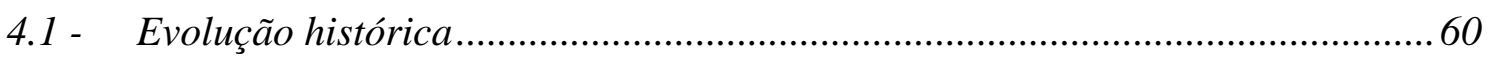

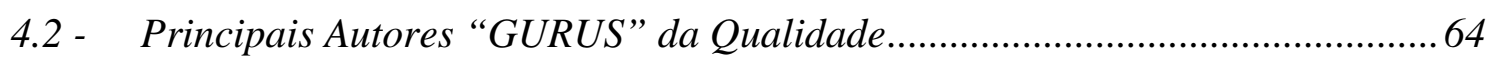

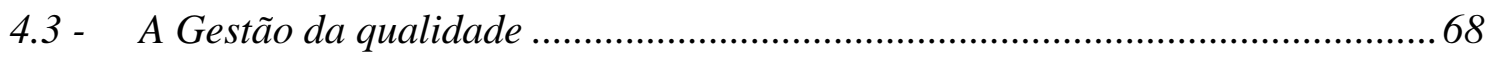

4.3.1 - A Gestão da Qualidade na pequena empresa ...................................................69

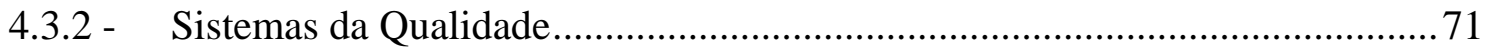

4.3.3 - Implantação de sistemas da qualidade......................................................... 74

4.4 - $\quad$ O modelo ISO 9000 de sistema da Qualidade .................................................... 78

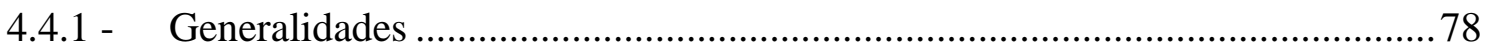

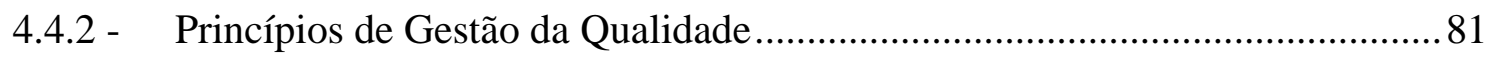

4.4.3 - Escopo do Sistema de Gestão da Qualidade.................................................. 82

5 - PROCEDIMENTOS METODOLÓGICOS.................................................85

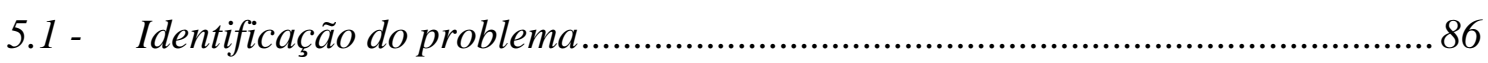

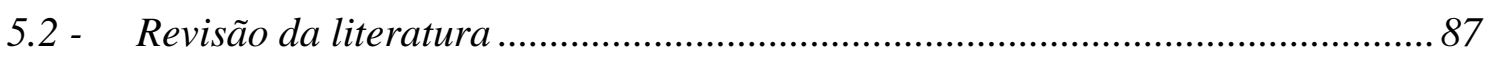

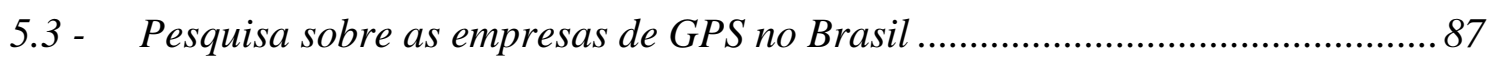

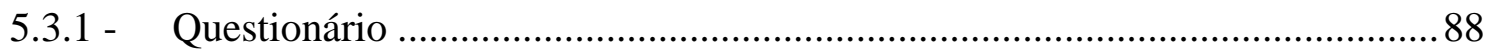

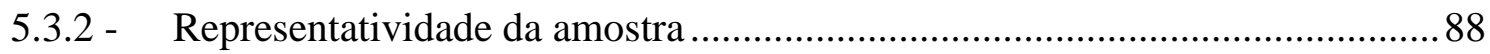

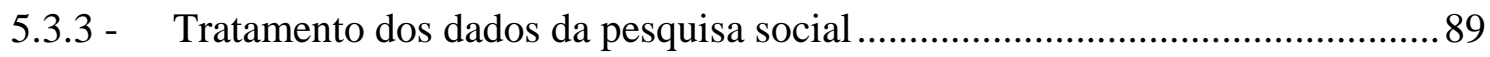

5.4 - A Empresa Genérica de serviços com GPS........................................................ 90

5.5 - Elaboração do Programa (Modelo) de Gestão da Qualidade ............................ 91

5.6 - Adaptação e aplicação do modelo iso 9000 ...........................................................94

5.6.1 - Definição da unidade de negócio ..................................................................95

5.6 .2 - Definição da política e dos objetivos da Qualidade .......................................95

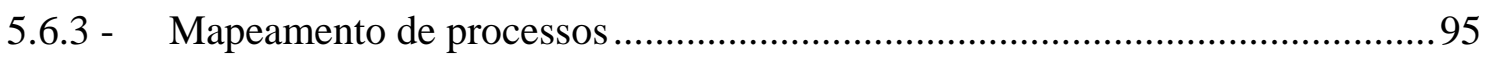

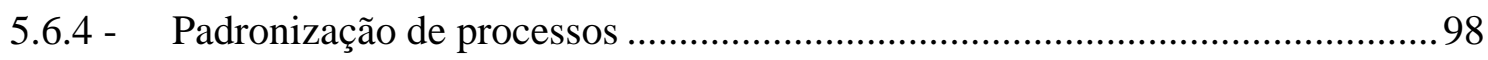

5.6.5 - Delineamento do Sistema de Gestão da Qualidade .........................................100 
6 - O PROGRAMA DE GESTÃO DA QUALIDADE PROPOSTO..................101

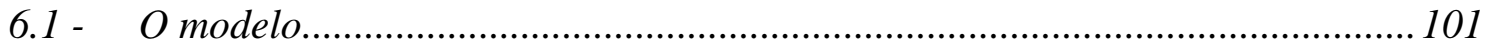

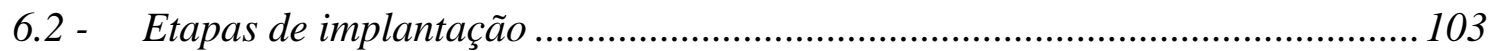

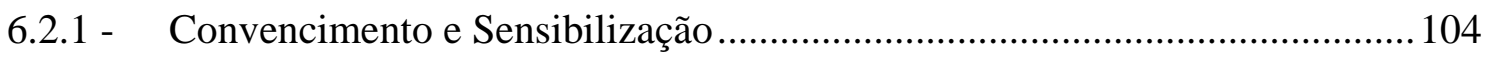

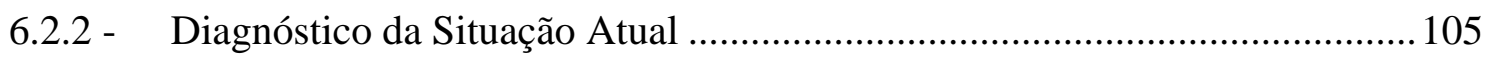

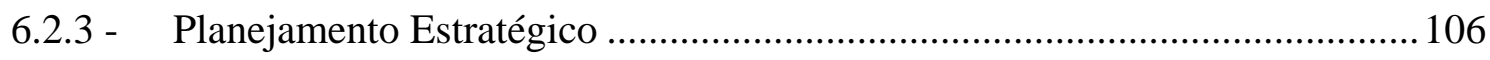

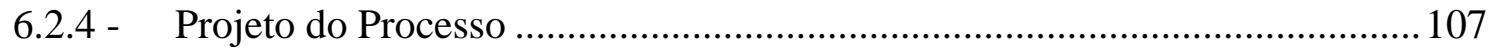

6.2.5 - Gerenciamento Sistêmico por Processos........................................................ 110

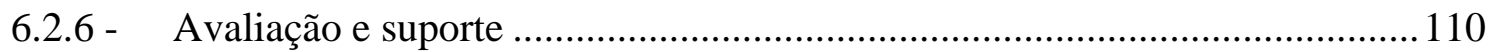

6.2.7 - Gestão da Qualidade e Manutenção do Sistema........................................... 111

6.3 - Viabilidade e recomendações de aplicação ...................................................... 112

6.4 - Elementos considerados para elaboração do modelo proposto ........................113

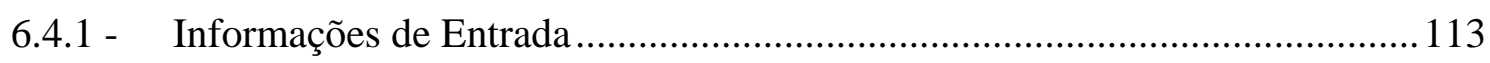

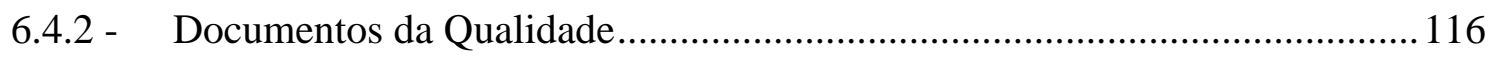

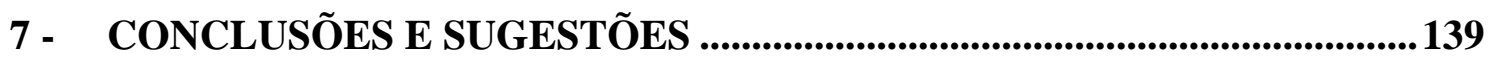

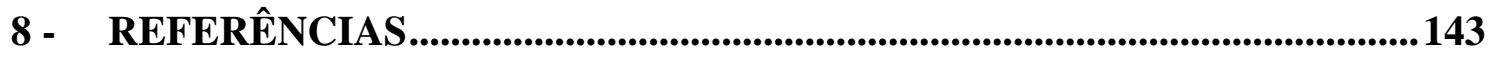

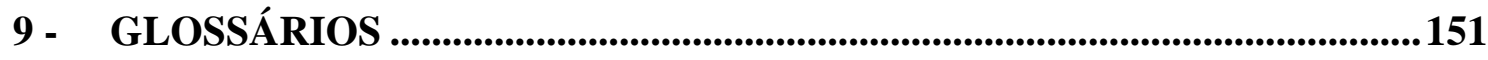

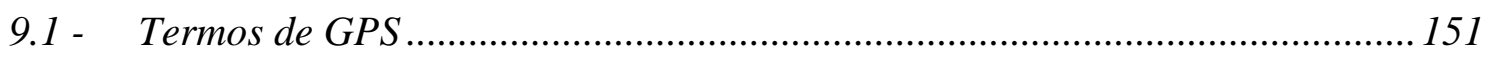

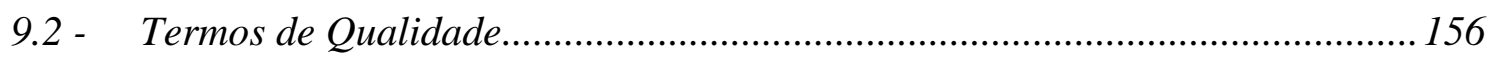

APÊNDICE A - Questionário submetido às Empresas de Posicionamento com o Sistema GPS .................................................................................... 167

APÊNDICE B - Resultados da pesquisa social aplicada a empresas de GPS .......173 APÊNDICE C - Registros de um posicionamento de campo com GPS (Exemplo Estático) .............................................................................179 


\section{1 - INTRODUÇÃO}

Este trabalho propõe um Modelo de Gestão da Qualidade para uma empresa genérica prestadora de serviços de posicionamento topográfico e/ou geodésico com equipamentos GPS, como alternativa para melhorar a gestão da organização e garantir a qualidade de seus serviços e produtos.

\section{1 - CONSIDERAÇÕES PRELIMINARES}

O Sistema de Posicionamento Global - GPS tornou-se uma ferramenta indispensável aos profissionais que trabalham na área de posicionamentos topográficos e geodésicos, pois, na maioria dos casos, as técnicas disponíveis dessa ferramenta proporcionam maior rapidez e confiabilidade nos resultados se comparadas com outras técnicas.

A alta eficiência e o desempenho proporcionados pelo sistema GPS provocaram uma verdadeira corrida mundial a essa tecnologia, que literalmente revolucionou a forma de execução dos posicionamentos topográficos e geodésicos. No Brasil, sua adoção está praticamente consolidada, pois os principais clientes (governamentais e/ou privados) tomaram-na como técnica de referência na contratação de serviços.

O aumento da demanda por esse tipo de serviço fez surgir novas empresas específicas no uso do sistema GPS e exigiu que as empresas antigas (usuárias de técnicas convencionais) se adaptassem para atender um mercado crescente e cada vez mais exigente. Por se tratar de um método novo, sua implantação requer mudanças significativas tanto de ordem técnica como administrativa. As de ordem técnica estão intimamente ligadas ao conhecimento especifico do sistema e suas capacidades, e as de ordem administrativa estão ligadas aos meios e políticas que permitam garantir uma gestão efetiva de todos os processos envolvidos na execução do serviço com o sistema GPS dentro da empresa (organização). 
O panorama atual das empresas prestadoras de serviços de posicionamentos topográficos mostra que, embora as empresas sempre busquem prestar um serviço com qualidade, são poucas as que realmente se dedicam e têm suas finalidades voltadas a uma sistemática de controle e Gestão da Qualidade, seguindo um padrão préestabelecido.

Segundo a AETESP (2001), o que se vê é um verdadeiro leilão de preços em que figuram empresas que possuem pouco conhecimento sobre as técnicas modernas de medições topográficas e clientes sem informações para exigirem serviços de qualidade. O resultado tem sido o descrédito do setor, com a constante ação de pessoas sem as devidas qualificações que prestam serviços lançando mão de expedientes escusos, tais como:

- emprego de mão de obra desqualificada para o desempenho técnico;

- falta de preocupação a qualidade técnica dos serviços prestados;

- $\quad$ sonegação de impostos;

- conluio com a fiscalização na aprovação de serviços mal executados etc.

As conseqüências dessa situação comprometem os resultados dos serviços prestados e os prazos, que se refletem diretamente na qualidade final do serviço.

A modernização imposta ao setor de topografia e geodésia em seu cenário produtivo e econômico, com o aparecimento de novas técnicas produtivas e ferramentas gerenciais, não pode mais ser protelado. Isto impõe às organizações uma necessidade emergencial de mudança e grandes desafios, entre eles o de sua própria sobrevivência.

A Qualidade é mundialmente reconhecida como um componente essencial da competitividade, e atualmente é encarada como uma necessidade por empresas de diversos portes e ramos de atividades para se adequarem às exigências e a dinâmica do mercado consumidor. No mundo todo, a crescente competitividade fez da qualidade o elemento diferencial para conquistar mercados e garantir a sobrevivência da organização. Isso mostra que a Qualidade se tornou palavra de ordem, isto é, quem desejar dispor de oportunidades iguais deve padronizar seus processos produtivos e o bem final, independente da origem ou do setor de atuação. 
Embora hoje esteja comprovada a eficiência dos sistemas de Gestão da Qualidade em muitos setores da indústria de transformação (manufatura), ainda se encontra resistência em setores com tradicional “inércia” a mudanças, como é o caso do setor de posicionamentos topográficos e geodésicos. Para muitos, nesse setor, parece complicado e muitas vezes complexo falar de qualidade, porém, observa-se que esta situação tem mudado, principalmente para atender e satisfazer as expectativas e exigências dos clientes com relação ao serviço prestado.

No Brasil, praticamente não existe material estatístico sobre a Qualidade no setor de posicionamento topográfico e geodésico. Por esse motivo, decidiu-se realizar neste trabalho uma pesquisa social independente, com a intenção de conhecer a situação das organizações que especificamente prestam os serviços de posicionamento com o sistema GPS. A pesquisa foi feita por meio de um questionário enviado a uma série de empresas, no qual foram coletadas informações básicas sobre a Gestão da Qualidade. Os resultados, após tabulados, foram analisados e usados como motivadores para o desenvolvimento desta tese.

\section{2 - DELIMITAÇÃO DO PROBLEMA E OBJETIVOS}

A execução de um serviço de posicionamento topográfico e/ou geodésico com o sistema GPS consiste de uma seqüência de procedimentos práticos que, se forem bem executados, proporcionarão maior probabilidade de êxito no resultado final. Tais procedimentos dependem muito de cada caso, e normalmente são definidos por indicações dos fabricantes dos instrumentos, normas e especificações oficiais, e, na maioria das vezes, pela própria experiência prática do responsável.

Esta tese propõe uma forma técnica (modelo) para melhorar a qualidade dos serviços prestados com o uso do sistema GPS. Considera como principal alternativa o uso de ferramentas de gestão e controle, aplicadas em toda a empresa (organização) e particularmente na execução dos serviços. O enfoque principal é a parte produtiva dos serviços efetuados com esse sistema, por ser considerado o elemento fundamental de qualquer posicionamento com GPS. 
Em uma empresa de serviços de posicionamentos topográficos e/ou geodésicos com o sistema GPS (que deste ponto em diante será chamada apenas de “empresa de GPS”) entende-se que a Garantia da Qualidade de seus produtos e serviços está intimamente ligada aos procedimentos e controles utilizados para sua obtenção. Segundo Marques et al. (2004), a maioria dessas empresas adota políticas de gestão completamente informal, o que dificulta muito a possibilidade de um controle de qualidade mais eficiente.

A implantação de um Sistema da Qualidade em uma empresa de GPS requer dessa organização a disposição para implantar políticas de qualidade em todos os setores e por todos os cantos, sem distinção, isto é, torna-se necessário conhecer e controlar todos os seus processos. Como a maioria das empresas de GPS tem características semelhantes, a proposta desta tese foi desenvolver um programa (modelo) de Gestão da Qualidade para uma empresa genérica, que pudesse servir de guia para implementação em uma empresa com características similares, além de prover informações gerais a respeito do tema.

\subsection{1 - Objetivos}

O objetivo principal desta tese é propor um programa (modelo) de Gestão da Qualidade para uma empresa genérica de posicionamento com o sistema GPS.

E como objetivos específicos têm-se:

- executar uma pesquisa social, para identificar como agem as empresas que prestam serviços de posicionamento com o sistema GPS no Brasil;

- fazer a caracterização dos principais métodos usados para garantir a qualidade dos serviços de posicionamento com o sistema GPS no Brasil; e

- elaborar um padrão (modelagem) dos processos básicos de uma empresa genérica de serviços de posicionamento com o sistema GPS.

\section{3 - JUSTIFICATIVA}

Com a implantação da Lei 10267/INCRA (BRASIL, 2001), que criou a obrigatoriedade do georreferenciamento de propriedades rurais, o setor de posicionamento topográfico e geodésico tem passado por um processo de adequação para atender as exigências da lei. Tais exigências indicam um forte crescimento da preocupação com a qualidade dos 
serviços, tornando-a um importante diferencial para a sua contratação. Além disso, a crescente adoção de padrões de qualidade e critérios de aceitabilidade na aquisição de produtos mostra também uma maior preocupação dos clientes, com relação ao valor pago na hora de contratar um serviço. Em outras palavras, está havendo um maior discernimento na análise da relação custo x benefício, fato que tecnicamente é favorável a ambos os lados, o cliente (consumidor) e a empresa (produtor).

As recentes mudanças de exigências por parte dos principais clientes dos serviços de topografia e geodésia, principalmente com o surgimento das novas tecnologias de produção, têm provocado verdadeiros abalos nas estruturas tradicionais das empresas do setor. Segundo Marques et al. (2004), o principal motivo é a ausência de um sistema de organização técnica mais eficiente, capaz de suportar a pressão do mercado e atender satisfatoriamente as novas exigências.

Apesar da Qualidade ser atualmente considerada um modismo, em alguns casos até excessivo, é fundamental para uma empresa (independente do porte ou setor) ter um Sistema da Qualidade. A Gestão da Qualidade fornece uma estrutura consistente na administração de uma organização, aproximando todos os aspectos das operações, o que torna possível planejar, fabricar e entregar um produto ou serviço com qualidade. Em outras palavras, promove uma cultura organizacional, na qual todos os procedimentos de qualidade ficam sujeitos a uma avaliação e melhoria contínua em todo o sistema.

A implantação e adaptação das teorias da Qualidade (originadas dos setores tradicionais da indústria de transformação) para a realidade do setor de serviços de posicionamentos topográficos e geodésicos tornaram-se um desafio, em virtude da complexidade do processo e das características especificas do setor, tais como: número reduzido de funcionários; produtos normalmente únicos e não seriados; produção centralizada (produto fixo); mão de obra altamente qualificada com escassa possibilidade de promoção; serviços realizados sob intempéries; especificações desatualizadas; ausência de fiscalização, etc. (MARQUES e SILVA, 2003). Também há uma ausência generalizada do uso de ferramentas técnicas de gestão que garantam uma combinação da estrutura operacional de trabalho (documentada em procedimentos gerenciais técnicos) e direcionem as ações coordenadas (de mão de obra, equipamentos e informações) conforme os mais práticos meios de assegurar a satisfação quanto à 
qualidade e os custos. Outro fator importante é a carência de material bibliográfico sobre o assunto na área de posicionamentos topográficos e geodésicos.

Este trabalho não tem a intenção de minorar ou modificar os atuais métodos adotados por quem quer que seja, nem tão pouco, pretende esgotar as discussões sobre o tema. A intenção é apresentar com embasamentos técnicos um programa (modelo) de Gestão da Qualidade para uma organização genérica de posicionamento com o sistema GPS.

\section{4 - FONTES DE DADOS}

Este trabalho foi planejado e desenvolvido no Departamento de Transportes da Escola de Engenharia de São Carlos da Universidade de São Paulo. Teve como fonte técnica de direcionamento das ações os resultados de uma pesquisa qualitativa (Apêndice B) realizada por meio de um questionário eletrônico, com questões abertas, que foi submetido a várias empresas de GPS no Brasil. A pesquisa foi independente e realizada durante 5 meses, por meio da internet, para identificar a situação das empresas com relação à qualidade e coletar sugestões sobre o assunto.

A pesquisa bibliográfica, tanto na área de GPS como na de Gestão da Qualidade, consistiu em consultas a diversas publicações avulsas, livros, artigos em revistas, teses, dissertações, monografias, anais de congressos e relatórios científicos de grupos de pesquisas buscados em bibliotecas e por meio de acessos a páginas da internet.

A experiência prática do autor e dos colaboradores na realização de inúmeros serviços com GPS também foi fundamental na definição dos elementos chaves para elaboração das diretrizes do programa de qualidade proposto.

Como ilustração da importância de um Sistema de Gestão da Qualidade em uma empresa de GPS, considerou-se a aplicação de padrões técnicos (modelos) no processo produtivo de um posicionamento típico pelo método estático. O padrão técnico adotado norteou todo o processo, minimizando os retrabalhos e os custos operacionais, conforme é apresentado no Apêndice C. 


\section{5 - ESTRUTURA DO TRABALHO}

O capítulo 2 trata do Sistema de Posicionamento Global - GPS, generalidades, princípio de uso, principais componentes de recepção e suas classificações, aplicações e métodos de posicionamentos. Apresentam-se também considerações sobre as principais normas nacionais e internacionais usadas para posicionamento com o sistema GPS e suas relações com a qualidade.

O capítulo 3 enfoca os serviços com GPS. São apresentados os diferentes tipos de organizações prestadoras de serviços, uma descrição do produto base e dos principais clientes, o modelo genérico adotado de uma empresa de posicionamento com o sistema GPS, as fases do ciclo de vida de um serviço com GPS, e as formas mais usadas de gestão organizacional em empresas de serviços com GPS.

O capítulo 4 expõe a Gestão da Qualidade, sua evolução histórica, definições dos principais autores da Qualidade, a Gestão da Qualidade em ambiente empresarial e na pequena empresa, os passos para a implantação de um Sistema de Gestão da Qualidade e a estrutura de requisitos da ISO 9000:2000.

Os capítulos anteriores foram auxiliares para o entendimento das características que deveriam ser consideradas na elaboração de um Programa (Modelo) de Gestão Qualidade para uma empresa genérica de GPS, também apoiaram a escolha das estratégias e forneceram indicações da importância de uma definição adequada da qualidade no contexto de cada ambiente.

O capítulo 5 relata os procedimentos e métodos usados no trabalho para: a coleta dos dados da pesquisa social nas empresas de posicionamento com o sistema GPS; a elaboração do programa (modelo) de Gestão da Qualidade adaptado da ISO 9000; e o exemplo de posicionamento com GPS, considerando o padrão aplicado no processo produtivo.

O capítulo 6 apresenta a proposta do modelo de Gestão da Qualidade para uma empresa genérica de GPS, com descrição das etapas de implantação, viabilidade e recomendações de aplicações e também os elementos considerados para elaboração do modelo. 
O capítulo 7 apresenta as conclusões obtidas a partir do estudo realizado e algumas recomendações para trabalhos futuros.

O capítulo 8 apresenta as referências bibliográficas consultadas para realização do trabalho.

O capítulo 9 inclui um glossário de termos usados em GPS e de termos usados na qualidade.

\section{Os Apêndices:}

- A contém os documentos usados para pesquisa social com as empresas de GPS;

- B contém os resultados da pesquisa social com as empresas GPS usados no trabalho;

- C contém o relatório do uso de um padrão de qualidade em um exemplo de posicionamento com GPS. 


\section{2 - O SISTEMA GPS}

\section{1 - GENERALIDADES}

O GPS (Global Positioning System) é um sistema de posicionamento global que possibilita ao usuário determinar sua posição tridimensional em qualquer lugar da terra ou em suas proximidades. Os sistemas de navegação por satélites no mundo e suas possíveis integrações, inclusive com os em desenvolvimento, têm sido representados pelo termo GNSS (Global Navigation Satellite Systems). Existem atualmente dois sistemas em operação: o americano NAVSTAR (NAVigation System with Timing and Ranging) e o russo GLONASS (Global Navigation Satellite System), ambos públicos e de domínio do estado. Um outro sistema denominado GALILEO encontra-se em desenvolvimento por parte da iniciativa privada da comunidade européia. A China e o Japão também têm cogitado desenvolver seus próprios sistemas.

É comum chamar somente de GPS ao sistema americano, por ter sido o primeiro difundido e disponibilizado à comunidade civil. Tanto o NAVSTAR como o GLONASS apresentam características básicas de funcionamento (operacionalização de campo) muito semelhantes. Neste trabalho os enfoques serão mais específicos ao sistema NAVSTAR por ser o mais usado pela comunidade civil nos posicionamentos topográficos e geodésicos de precisão.

Embora o objetivo principal do GPS seja fornecer capacidade de posicionamento para as forças armadas e seus aliados na terra, no ar e no mar, o sistema está disponível livremente a qualquer usuário. Para a comunidade civil é disponibilizado um subproduto do sistema, com restrições e limitações de uso impostas pelos órgãos gestores (DoD) que detêm o controle sobre os níveis de desempenho do sistema. 
Apesar das limitações, a facilidade de operação e a precisão proporcionada pelo sistema fizeram crescer o número de usuários civis (superando os militares) em áreas como navegação, monitoramento de obras e meio ambiente, agricultura de precisão, controle de frotas, meteorologia, Sistemas de Informação Geográfica, posicionamentos topográficos e geodésicos de precisão e outros.

\subsection{1 - Aplicações do GPS}

Dentre as diversas aplicações civis destacam-se as realizadas na superfície terrestre:

- posicionamento e mapeamento: redes cadastrais e urbanas, coleta de dados para Sistemas de Informação Geográficas (SIG), posicionamentos para obras de engenharia, controle terrestre para fotogrametria (no ar e na terra) e posicionamentos de recursos geofísicos.

- aplicações geodésicas: estabelecimento de redes de controle em diversos níveis de extensão regional e continental, posicionamento e monitoramento para engenharia de precisão.

- aplicações Geodinâmicas: medições de posição relativa (rede) em intervalos regulares para deduzir movimentos horizontais e verticais da crosta terrestre.

Normalmente as aplicações de posicionamento com GPS são baseadas em exigências de precisão. Uma aproximação conveniente pode ser feita conforme indicado na Tabela 1.

Tabela 1 - Classificação das aplicações de posicionamento com GPS

\begin{tabular}{l|l}
\hline Classificação & Exigência de precisão \\
\hline Categoria A (científica) & Menor que $1 \mathrm{ppm}$ \\
\hline Categoria B (geodésica) & de 1 a $10 \mathrm{ppm}$ \\
\hline Categoria C (topográficas) & de $10 \mathrm{ppm}$ a $0,5 \mathrm{~m}$ \\
\hline Categoria D (levantamentos para SIG) & de 0,5 a $3 \mathrm{~m}$ \\
\hline
\end{tabular}

- A categoria A engloba os posicionamentos para engenharia de precisão, análise de deformação e principalmente aplicações geodinâmicas. É pioneira no uso de "tecnologia de ponta" para o desenvolvimento de novos instrumentos e estratégias de processamento que podem ser adotadas posteriormente pelas categorias B, C e D;

- A categoria B inclui pesquisas geodésicas para o estabelecimento, densificação e manutenção de redes de controle e apoio à cartografia;

- A categoria $\mathbf{C}$ envolve posicionamentos de precisões mais baixas no campo da topografia (implantações de apoio urbano, cadastral, geofísico e locações de obras). 
- A categoria D contempla os posicionamentos cadastrais para gestões de SIGs e outras aplicações da cartografia de propósitos gerais e temáticos. Junto com as categorias $\mathbf{B}$ e $\mathbf{C}$ formam a maioria dos usuários da comunidade civil.

Essa classificação é completamente arbitrária e não reflete qualquer "ordem" de posicionamento definida por autoridades oficiais, no entanto, fornece uma forma conveniente de divisão dos posicionamentos com GPS que transmite as semelhanças e diferenças entre as categorias.

\subsection{2 - Composição de um equipamento GPS}

Para usar o sistema GPS um usuário precisa de um equipamento capaz de receber e decodificar o sinal emitido pelos satélites da constelação GPS. Esses equipamentos são conhecidos como receptores GPS e variam em características, capacidades e principalmente em custo, dependendo do fabricante e das finalidades de aplicação. As modificações freqüentes tanto em função dos avanços tecnológicos (acrescentados na modernização dos sistemas) como também da inclusão de aplicativos opcionais (oferecidos pelas empresas fabricantes), tornam difícil classificá-los adequadamente. De um modo genérico podemos considerar um equipamento de GPS composto pelos elementos indicados a seguir, que podem variar em função do uso do receptor como base ou remoto (Figuras 1 e 2):

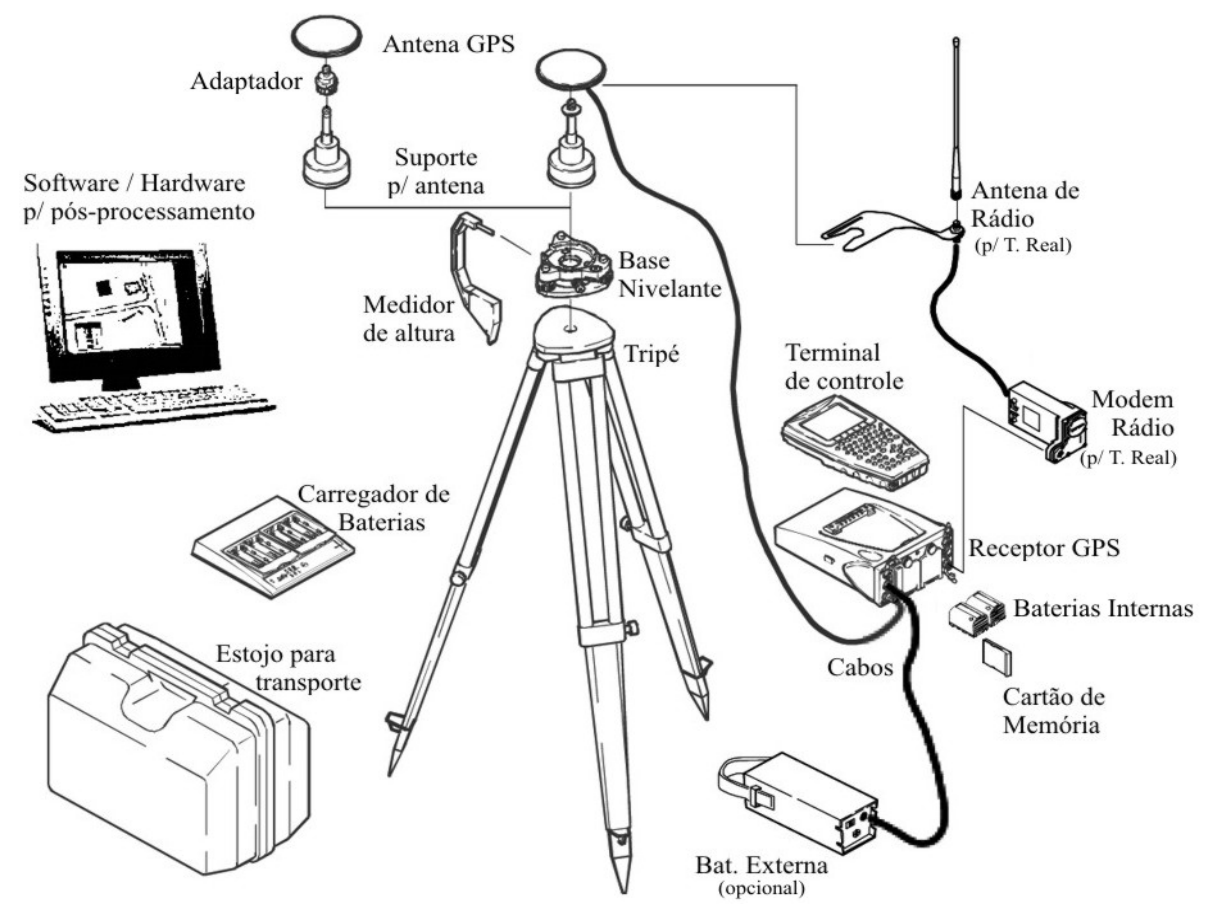

Figura 1 - Componentes de um equipamento GPS (Base) c/opção T. Real. Fonte: Adaptado pelo autor a partir de Leica Geosystems (2004). 


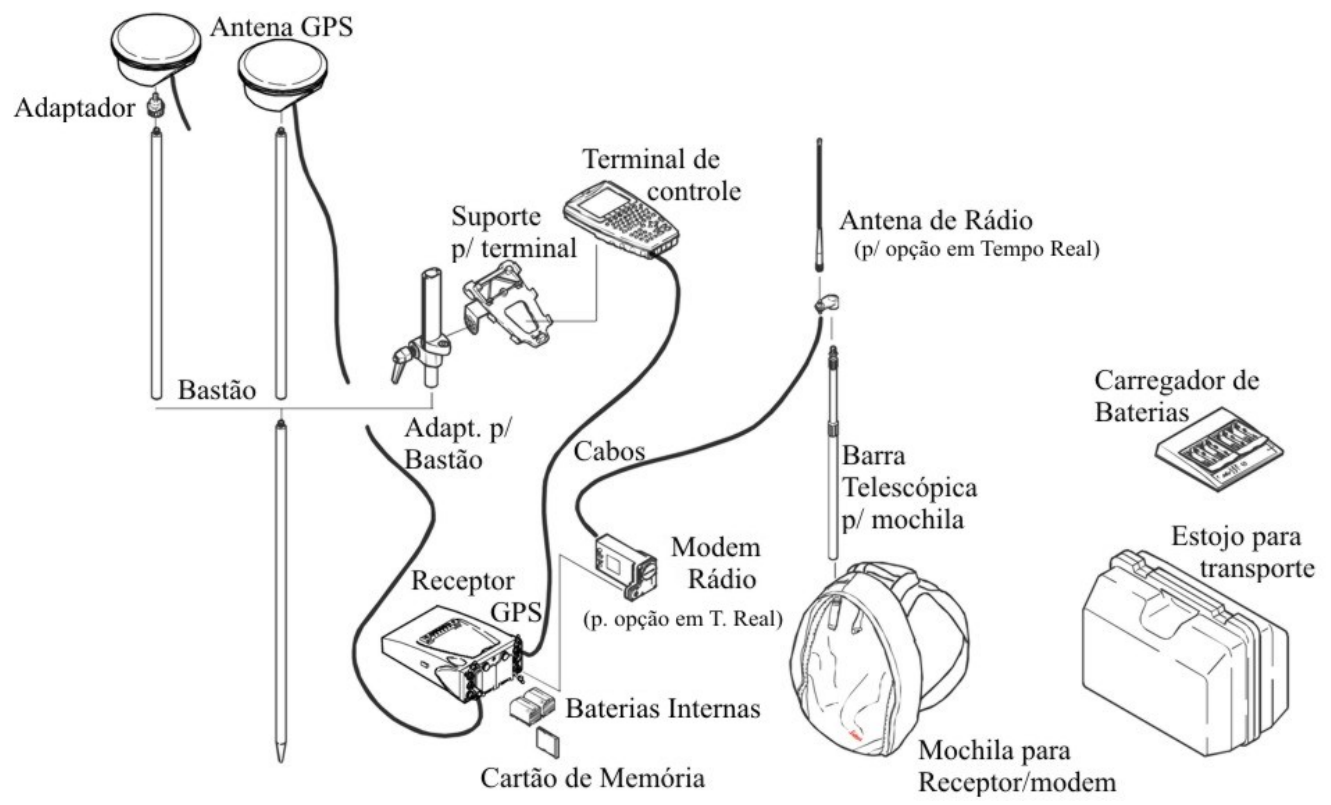

Figura 2 - Componentes de um equipamento GPS (Remoto) c/opção T. Real. Fonte: Adaptado pelo autor a partir de Leica Geosystems (2004).

\section{Antena GPS}

A antena GPS é responsável pela captação dos sinais dos satélites (Banda L) e submetêlos à seção de RF (Rádio Freqüência) para serem filtrados, amplificados e convertidos em impulsos elétricos a fim de serem utilizados pelos microprocessadores eletrônicos do receptor. Consiste basicamente em: elemento onidirecional; pré-amplificador eletrônico e opcionalmente dispositivo para minimizar efeitos de multicaminhamento "multi path". Os tipos mais comuns de antena para posicionamentos com GPS, conforme suas aplicações, são ilustradas na Figura 3.
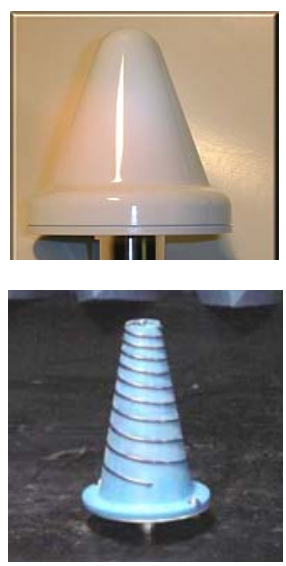

(a) Hélice Espiral (Mista)
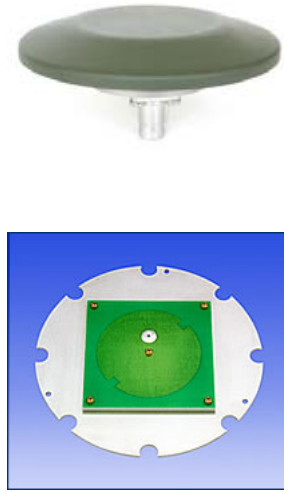

(b) Microstrip (Posicionamento)
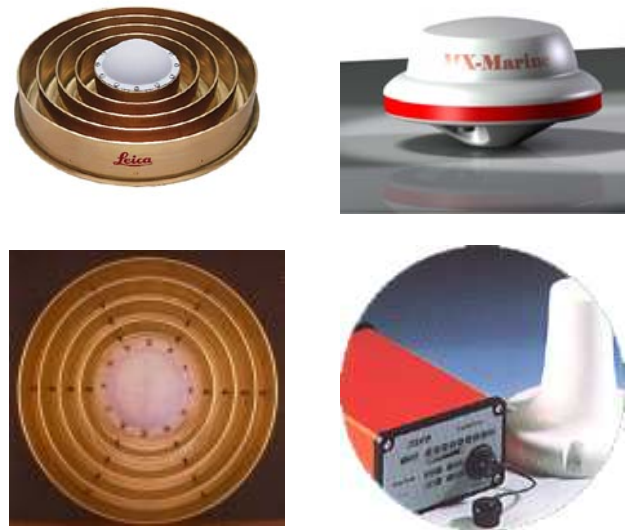

(c) Planar rings “ Choke ring” (Posicionamento)

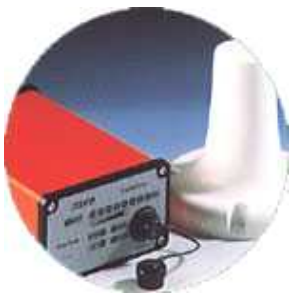

(d) Combinada Racal/Beacon (Posicionamento)

Figura 3 - Tipos de antenas GPS 


\section{Receptor GPS (Sensor)}

O GPS é o elemento principal do conjunto de recepção. Embora sua disposição física apresente várias configurações, a mais comum é conforme ilustrado nas Figuras 1 e 2, onde a unidade é modular formada pelos seguintes elementos fundamentais:

- Seção de Radiofreqüência - responsável pelo processamento eletrônico do sinal. Os sinais recebidos são submetidos a um refinamento (multiplicadores, filtros e misturadores) para eliminar ruídos e freqüências indesejadas.

- Microprocessador - responsável pelo controle de todas as operações do sistema de recepção, entre elas: a execução dos cálculos de posições e velocidades, o controle das funções de rastreamento e medições, a obtenção e processamento do sinal, a exibição de informações, etc.

- Dispositivo de armazenagem de dados (Memória) - nos receptores GPS para posicionamentos de precisão os dados coletados devem ser armazenados para posterior cálculo das linhas de base (pós-processamento). Normalmente emprega-se a memória interna física em meios sólidos, cartões de memória "removíveis", ou ainda em um “harddisk” (HD) de um computador, por meio de uma conexão (externa) direta.

\section{Suprimento de energia (Bateria)}

É responsável pelo fornecimento de energia que alimenta o sistema receptor durante o período de funcionamento. Pode ser interna e/ou externa ao módulo do sensor. Normalmente usam energia de baixa voltagem (DC) tornando-os autônomos, eficientes e flexíveis para operarem a partir de várias fontes de energia, tais como: baterias internas recarregáveis, pilhas alcalinas, baterias externas ou ainda a rede elétrica.

\section{Unidade de controle ou interface com o usuário (Terminal)}

É o elemento de interação com o usuário (teclas e display) que permite ao operador controlar e examinar as funções do microprocessador. Seu tipo e tamanho variam bastante, normalmente é fixo ao modulo do sensor ou compõe um modulo destacável (via cabo ou encaixe rápido), e apresenta vários tipos de interfaces eletrônicas para aplicações especializadas (modo de exibição, geração de saídas e interfaces para outros instrumentos). 


\section{Softwares para processamento GPS}

Há disponível no mercado uma grande variedade de pacotes de software para processamento dos dados GPS. Eles podem ser para aplicações em Tempo Real (instantaneamente) no próprio receptor ou para pós-processamento em um computador. Os pacotes de softwares normalmente são desenvolvidos pelos fabricantes dos receptores ou por universidades e entidades de governo (para uso em pesquisas científicas e propósitos operacionais internos). Os softwares apresentam detalhes de organização e integração (arquitetura) bastante variados e sua aplicação principal é o pós-processamento dos dados e a geração das coordenadas dos pontos medidos em um sistema de coordenadas pré-estabelecido.

O software GPS é um elemento fundamental que acompanha o equipamento de GPS e complementa o conjunto de recepção. Não existe o pacote ideal de software. Recomenda-se sempre seja usado o pacote do equipamento. Preferencialmente o software deve incluir:

- ajuda ao planejamento preliminar do posicionamento, decisão e reconhecimento;

- apoio às observações de campo (incluindo métodos de medição de alta produtividade como cinemáticos, rápido estático e outros derivados);

- pré-processamento e verificação dos dados;

- processamento de linhas de base,

- ajustamento e controle de qualidade de redes topográficas ou geodésicas e transformações dos resultados para o sistema de referência cartográfico estabelecido.

Um bom software GPS é aquele que proporciona ao usuário capacidade de explorar e avaliar seguramente todo o sistema (tanto o software como o hardware). Podem-se classificar os critérios usados para avaliar os softwares podem ser classificados em:

- Primários - envolvem a qualidade geométrica do processamento, suporte às técnicas de alta produtividade de posicionamento, eficiência do fluxo de dados e facilidade de operação.

- Secundários - envolvem o nível de automação, velocidade de processamento, flexibilidade de processamento, análise e capacidades de controle de qualidade dos dados, tipos de mídia e facilidade de manutenção, armazenagem dos arquivos de dados e exigências de I/O (input/output) e requisitos de hardware. 
Em suma, um comprador (usuário) na hora de adquirir um conjunto de recepção GPS deve ter claro o tipo de aplicação, a precisão e outras características operacionais que possam auxiliá-lo na identificação do conjunto hardware/software mais adequado às suas necessidades.

\subsection{3 - Princípio básico de funcionamento do GPS.}

O principio básico de funcionamento do GPS é a medição da distância entre a antena do receptor) e as antenas dos satélites da constelação GPS. A partir da medição dessa distância entre a antena do receptor e quatro satélites simultaneamente pode se determinar a posição (coordenada) da antena do receptor (Figura 4).

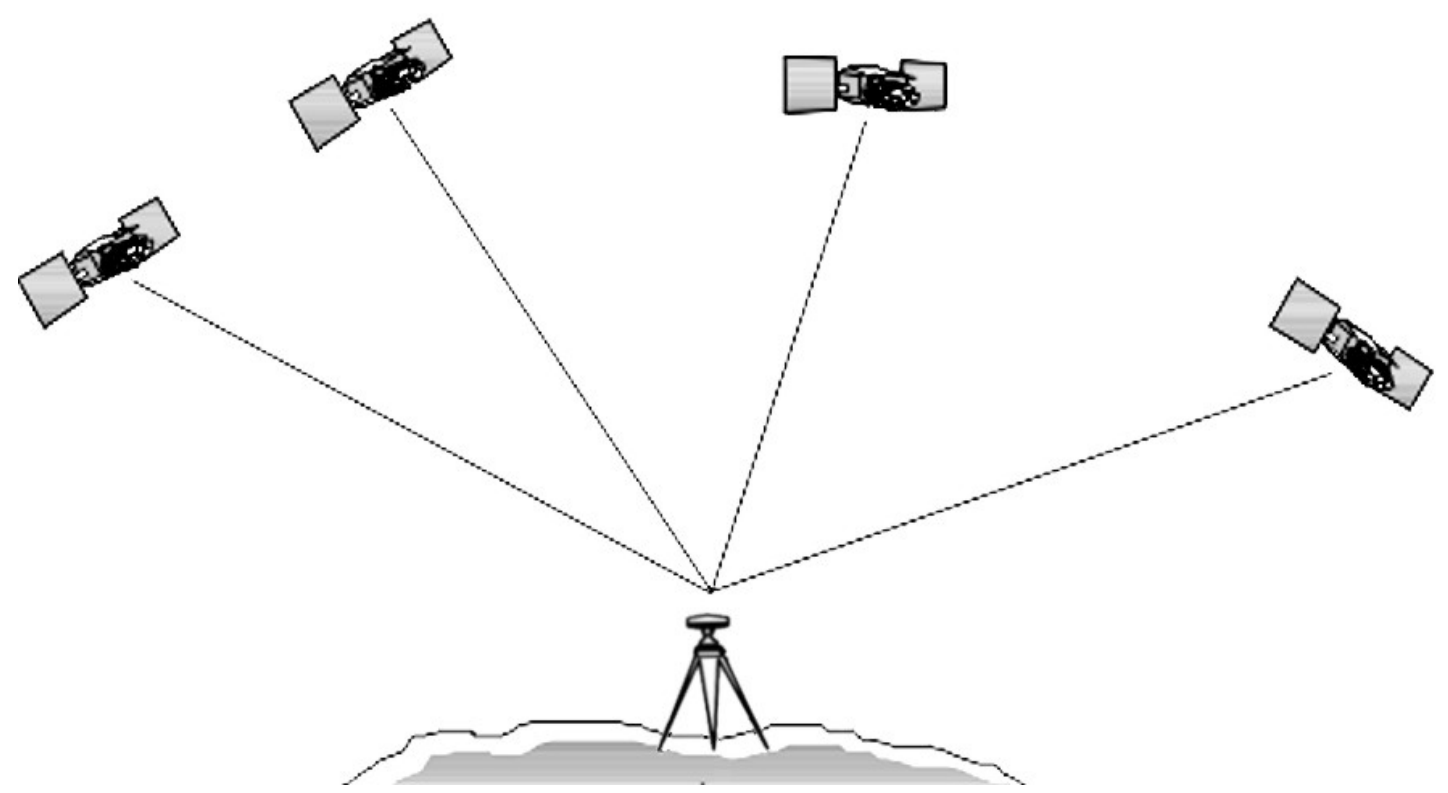

Figura 4 - Posicionamento Absoluto Estático

Neste trabalho optou-se por não apresentar algumas definições clássicas envolvendo características específicas do sistema GPS, tais como: o sinal transmitido (portadoras L1 e L2, códigos $\mathrm{C} / \mathrm{A}, \mathrm{P}$ e mensagens de navegação), métodos para se obter a pseudodistância (código e/ou fase da portadora), erros envolvidos nas observações (satélite, propagação do sinal e receptor), precisão do posicionamento e outros que são assuntos bastante difundidos e praticamente conhecidos por toda a comunidade usuária do sistema. Maiores detalhes sobre tais assuntos podem ser obtidos, entre outros, em Seeber (2000), Hofmann-Wellenhof, et al. (2001) e Leick (2004). 


\subsection{4 - Tipos de posicionamento com GPS}

Nos serviços com GPS, o posicionamento de um ponto é feito em relação a um sistema referencial geodésico. Basicamente são dois os tipos de operação com GPS, o posicionamento Absoluto e o posicionamento Relativo.

Um posicionamento é dito Absoluto quando se determinam as coordenadas da antena do receptor diretamente a partir das coordenadas conhecidas dos satélites GPS que estão sendo rastreados (Figura 4). Quando a posição é obtida instantaneamente diz que se tem uma coordenada de navegação. Quando ela é determinada a partir do processamento de dados coletados e armazenados no receptor, diz que se tem uma coordenada posicionada por ponto simples - PPP.

No posicionamento é dito Relativo quando as coordenadas desejadas são determinadas a partir do pós-processamento ou a partir do processamento em Tempo Real, dos dados coletados por dois ou mais receptores rastreando os mesmos satélites em um espaço de tempo definido. Neste caso a antena de um dos receptores, denominada remoto, é colocada sobre o ponto a ser determinado as antenas dos demais receptores, denominadas, base, são colocadas sobre pontos de coordenadas conhecidas (Figura 5).

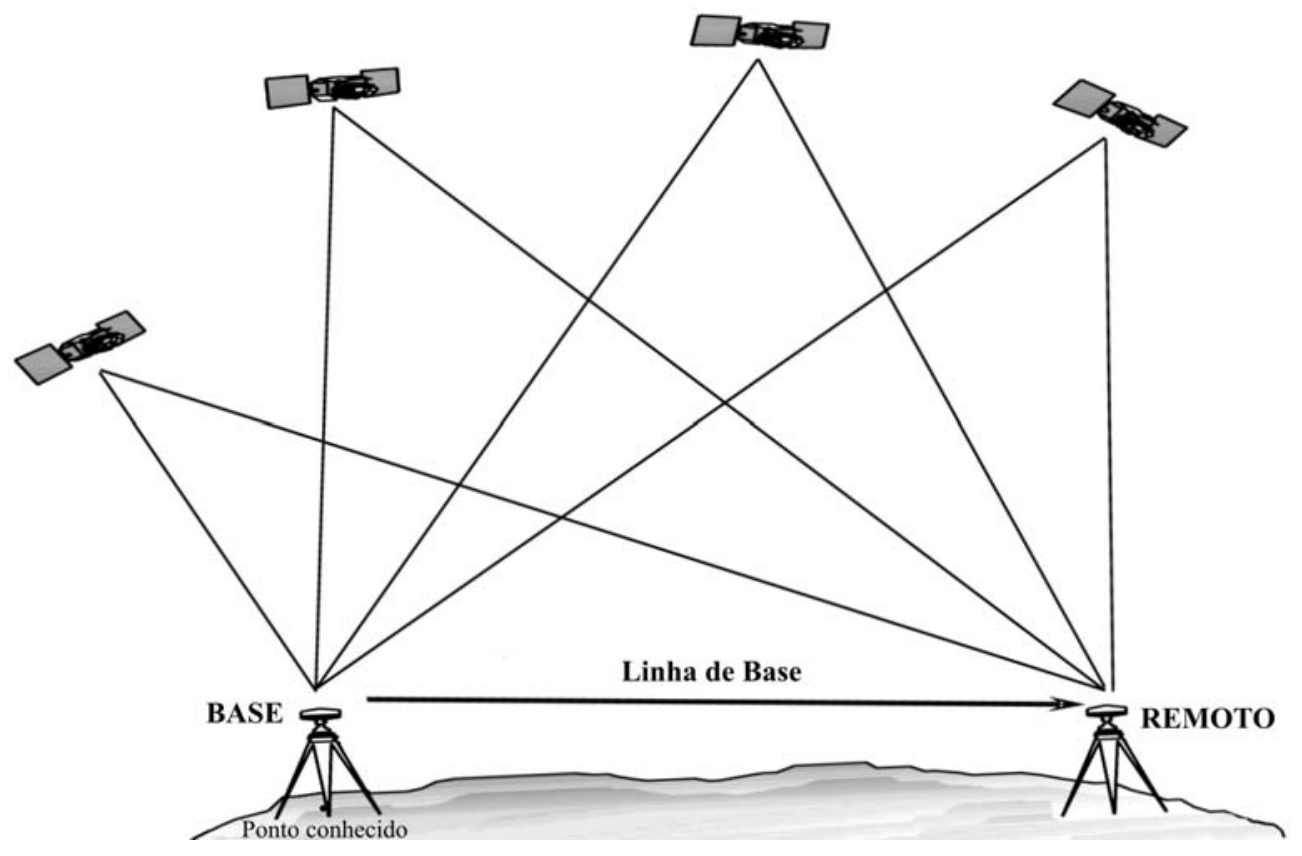

Figura 5 - Posicionamento Relativo Estático 
Em geral, os posicionamentos, quando em modo Absoluto, alcançam precisões instantâneas da ordem de 10 metros ou precisões processadas como parte simples da ordem 1-3 metros, que para a topografia e a engenharia de precisão são consideradas pouco precisas. As precisões nestes casos deveriam ser da ordem centimértrica, ou melhor. Já os levantamentos no modo relativo permitem alcançar precisões milimétricas, as quais são adequadas para os trabalhos de topografia e geodésia.

\subsection{5 - Métodos de posicionamento Relativo com GPS}

Um posicionamento relativo com GPS pode ser realizado pelo método estático, quando a antena do receptor remoto permanece em repouso durante a observação (Figura 5) ou em modo cinemático quando a mesma se movimenta durante a observação (Figura 6).

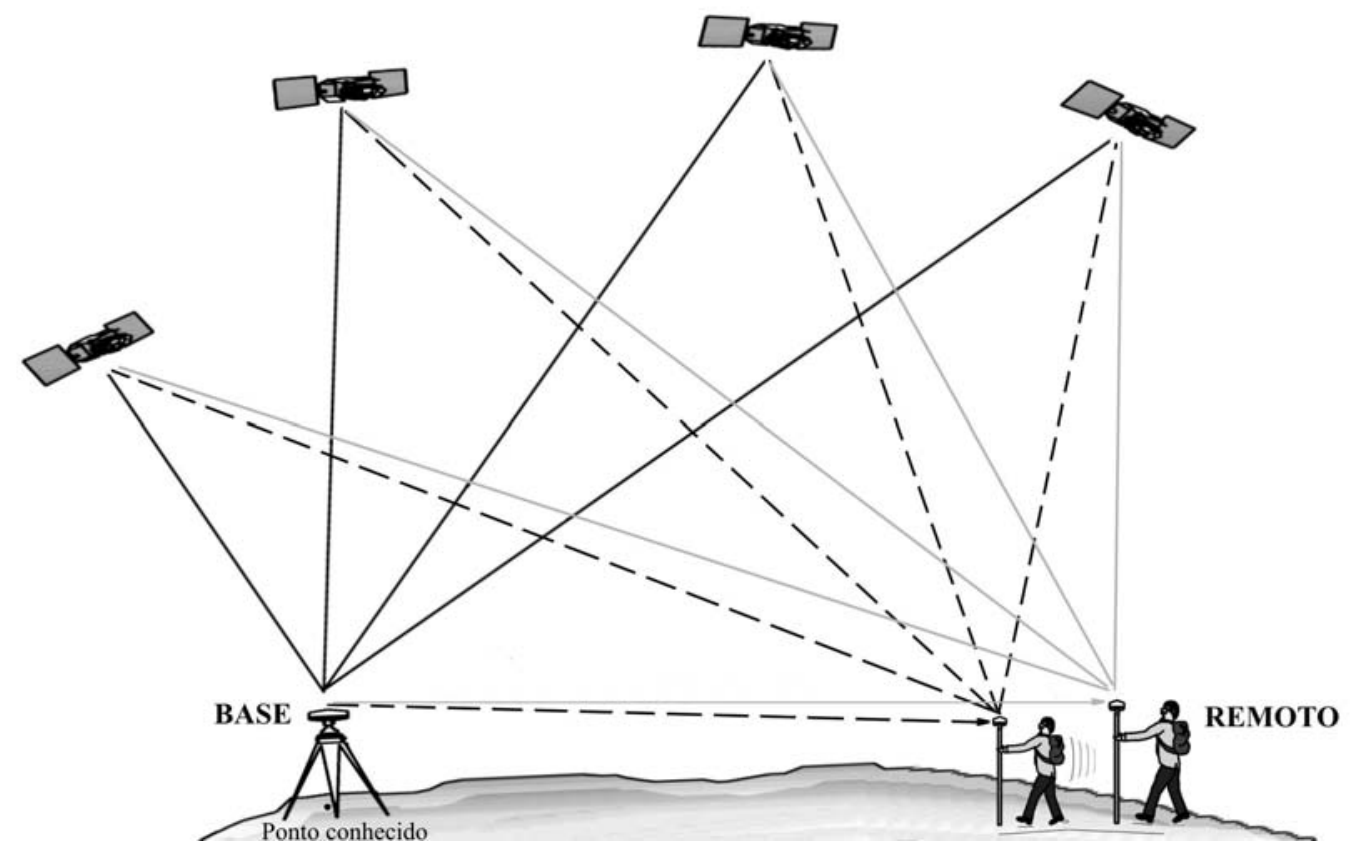

Figura 6 - Posicionamento Relativo Cinemático

\section{Método Estático}

Neste método usam-se dois ou mais receptores para coletar os dados (medidas) do código ou da fase das portadoras simultaneamente. A coleta dos dados pode variar de minutos a algumas horas dependendo do comprimento da linha de base, do número de satélites observados, da geometria entre os satélites e os receptores, do tipo de receptor (simples ou dupla freqüência) e da precisão final pretendida. As coordenadas dos pontos remotos são determinadas a partir do pós-processamento dos dados coletados pelos receptores remotos e pelo receptor base de coordenada conhecida. 
O posicionamento com GPS no modo relativo pelo método estático (Figura 5) é a técnica de posicionamento precisa mais utilizada nos serviços de campo, pois permite alcançar precisões da ordem de 1ppm, com o uso de receptores de dupla freqüência. É aplicado para implantação de pontos de apoio e controle, tais como: estabelecimento de redes geodésicas (regionais, nacionais e internacionais), deslocamentos de placas tectônicas, deformações de barragens e outras estruturas e obras em geral que necessitam de precisão elevada.

\section{Método Cinemático}

Neste método também se usam dois ou mais receptores. Pois, ao contrário do método estático, o receptor remoto se mantém em movimento durante o levantamento. Neste caso os receptores de base (fixos) ocupam estações de coordenadas conhecidas e os receptores remotos percorrem os locais de interesse, coletando dados simultaneamente dos mesmos satélites (Figura 6).

\subsection{6 - Técnicas para obtenção dos resultados com GPS}

Os resultados do posicionamento com GPS podem ser obtidos em Tempo Real no local do posicionamento ou depois de completada a missão (pós-processado). Em Tempo Real as posições são determinadas instantaneamente por meio de correções diferenciais, enquanto no modo pós-processado só após todos os dados terem sidos coletados e descarregados eles serão combinados e processados. A técnica de pós-processamento é realizada em uma etapa posterior ao posicionamento, na qual os dados coletados são refinados, combinados e processados conforme os critérios do projeto (Figura 7).

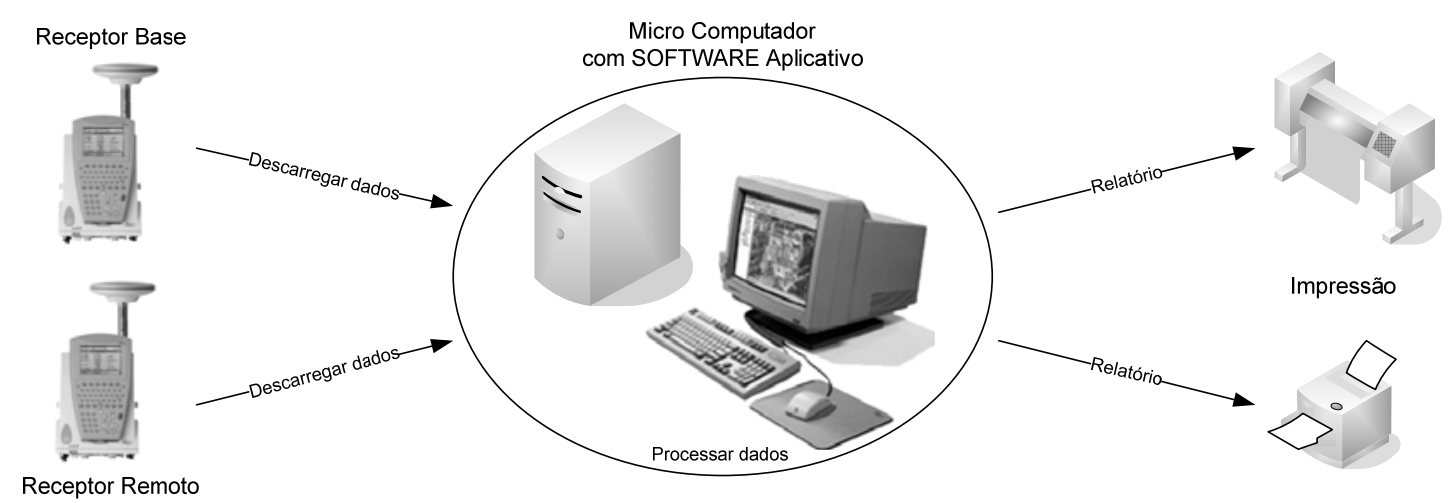

Figura 7 - Pós-processamento dos dados Relativos 
Nas medições em Tempo Real o resultado é instantâneo, realizado por meio da combinação dos dados coletados dos satélites GPS e das correções diferenciais recebidas por meio de um sistema de comunicação (rádio, telefonia ou satélites de comunicação). As técnicas de posicionamento em Tempo Real são conhecidas por: DGPS e RTK, sintetizadas a seguir.

A técnica DGPS (Diferencial GPS) usa as correções diferenciais baseadas na observação do código, sua precisão pode ser influenciada por fatores como o comprimento da linha base, a qualidade do sistema de comunicação, o cálculo das correções, a taxa de atualização e transferência dos dados além das grandezas observáveis empregadas. Com essa técnica é possível obter precisão horizontal de ordem submétrica, sendo freqüentemente empregada em reconhecimento do terreno, navegação e aplicações de cadastro e SIG’s. As correções diferenciais nas aplicações DGPS podem ser obtidas da seguinte forma:

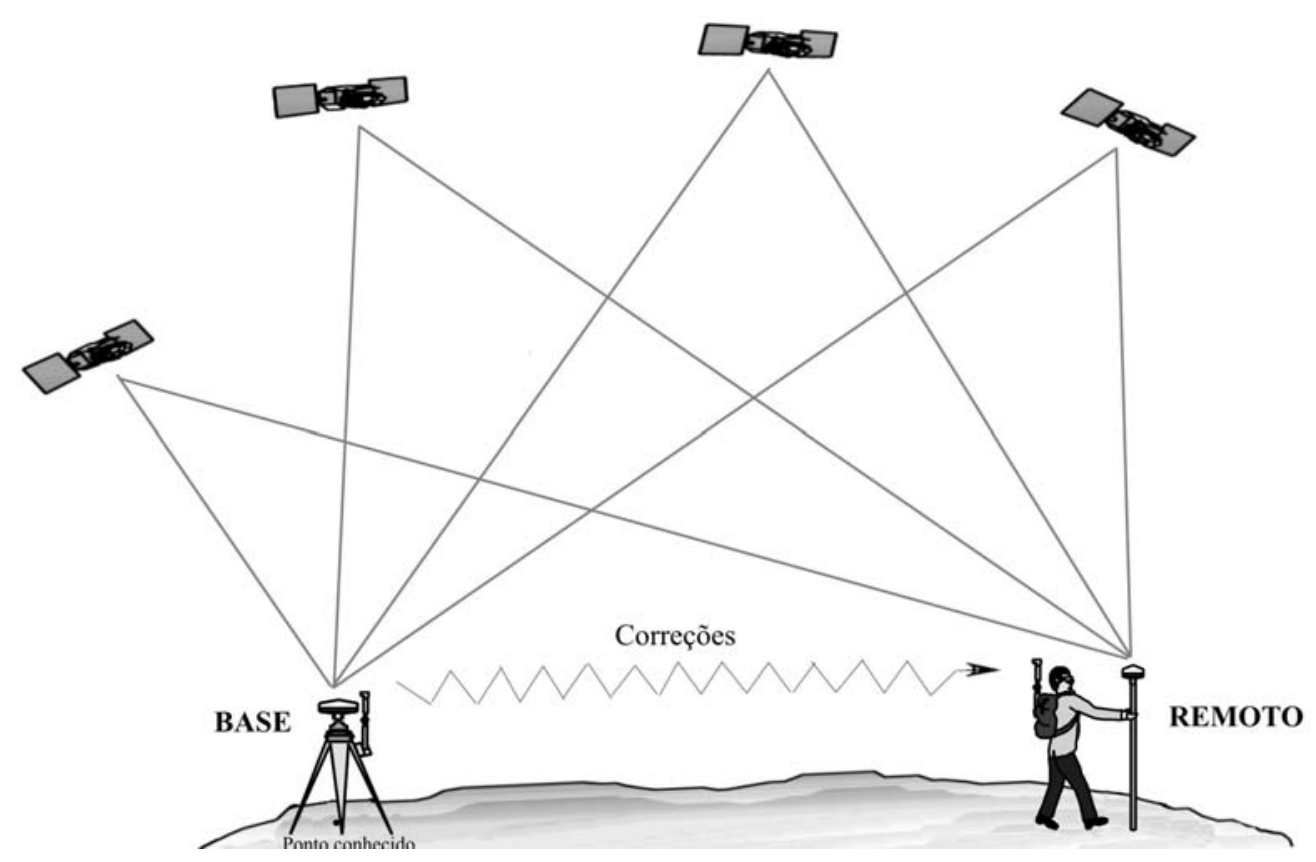

Figura 8 - DGPS - Correções Via Usuário

- A partir de uma estação de base (própria do usuário), em um ponto de coordenadas conhecidas e dotada de receptor GPS e rádio transmissor para enviar as correções até o receptor remoto no local do posicionamento (Figura 8); 
- Via satélite por meio de sistemas como OMNISTAR e RACAL, que consistem basicamente em uma rede de estações terrestres (WADGPS ${ }^{1}$ ) que recebem, calculam e enviam as correções a um satélite geo-estacionário que, por sua vez, retransmite à terra. O uso desse sistema implica, além do receptor GPS, na aquisição de um outro receptor especial (com custo aproximado de US\$ 4.000 mais licença em torno de US\$2.000/ano/receptor) para, em conjunto com o GPS, fazer o processamento em Tempo Real (Figura 9);

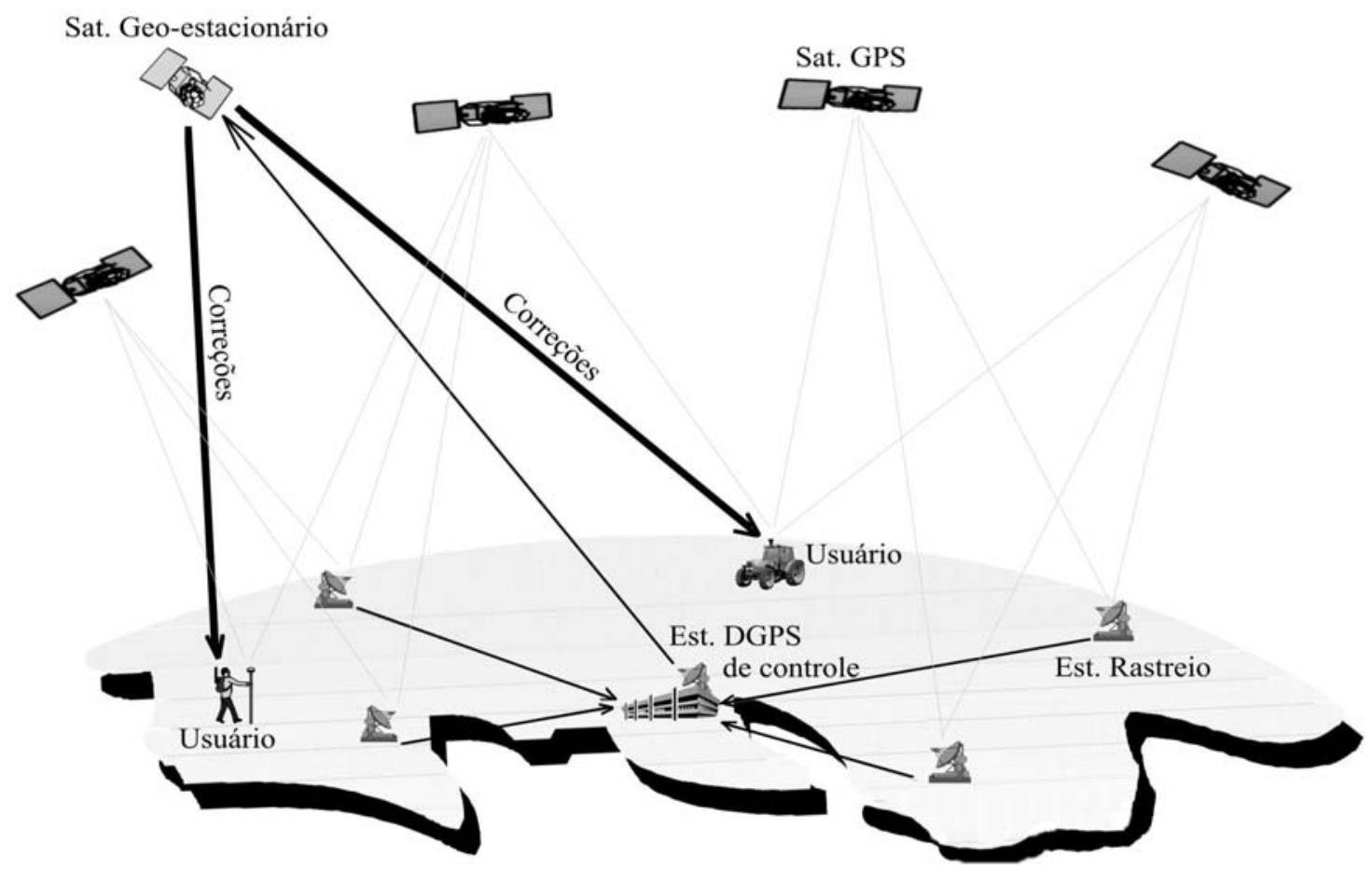

Figura 9 - DGPS - Correções Via Satélite

- Outra opção é através do sistema de radiofarol (BEACON) da marinha (Figura 10). Esse sistema também requer, além do receptor GPS, um outro receptor especial para decodificar o sinal com as correções recebidas dos radiofaróis. Embora apresente custos menores na maioria dos casos, tem a inconveniente limitação de área de atuação (restrito à região costeira).

\footnotetext{
${ }^{1}$ Sigla em inglês que corresponde a Wide Area Differential Global Positioning System.
} 


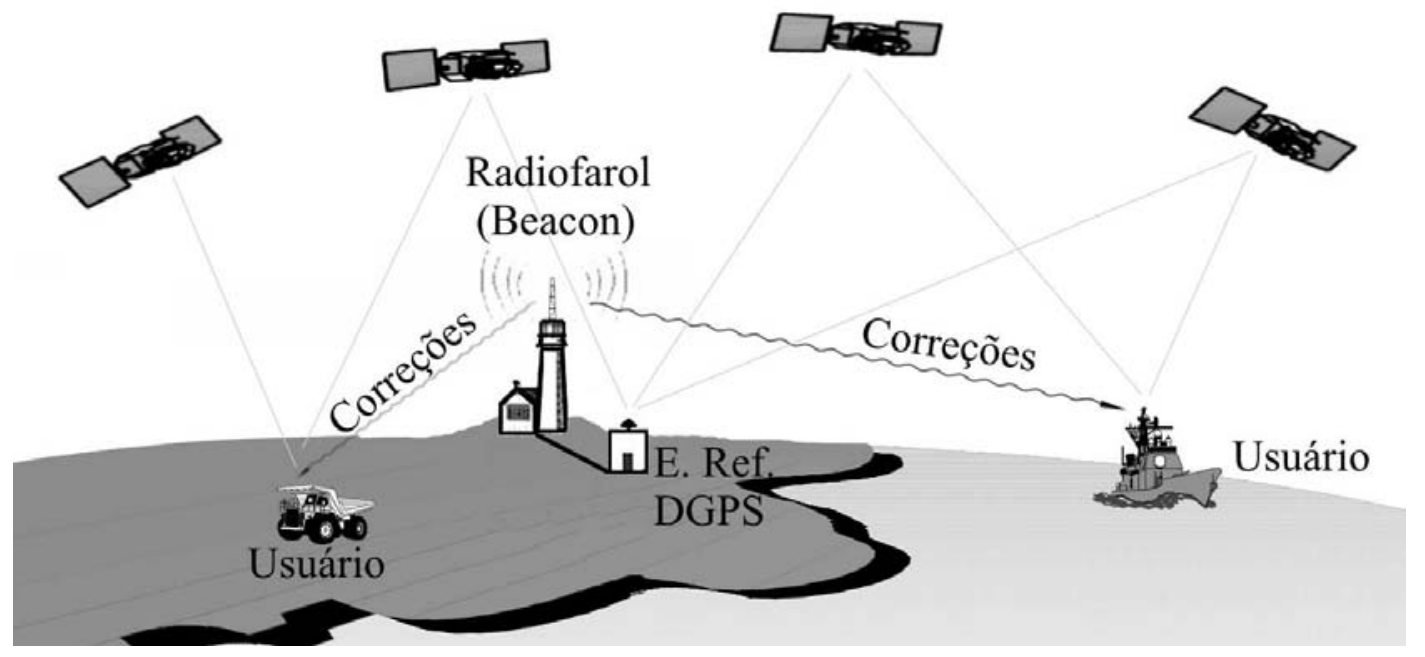

Figura 10 - DGPS - Correções Via Radiofarol (Beacon)

A Técnica RTK (Real Time Kinematic) usa como observável a fase da portadora, que, para obter resultado com precisão, necessita determinar a ambigüidade de ciclo. A solução clássica para resolver a ambigüidade considera um tempo mínimo de espera pelo receptor remoto antes de começar o posicionamento, no entanto, para muitos, isso pode significar perda de produção. Uma solução para esse caso é usar o método "OTF” que consiste em resolver a ambigüidade com o receptor em movimento.

Independente do método usado para resolver a ambigüidade, a técnica RTK necessita de equipamentos mais robustos e confiáveis como receptores de dupla freqüência (L1/L2), antenas capazes de minimizar efeitos de multicaminhamento e também um link de comunicação de alta freqüência para transferência da correção entre o receptor de base e o remoto. Essa técnica fornece precisões da ordem centimétrica, sendo mais freqüentemente usada nos serviços de locações de obras de engenharia, construção e aplicações de posicionamento de limites.

O link de comunicação entre os receptores influencia na área de trabalho que normalmente é inferior a $5 \mathrm{~km}$ e limita o potencial de exploração do método. Como alternativa, tem-se o PDGPS ${ }^{2}$, que da mesma forma que o WADGPS, fundamenta-se no conceito de rede de estações de referência (CORS - Continuously Operating Reference Station) e transmite as correções diferenciais na área da região abrangida pela rede (Figura 11).

\footnotetext{
${ }^{2}$ Sigla em inglês que corresponde a Precise Differential Global Positioning System.
} 


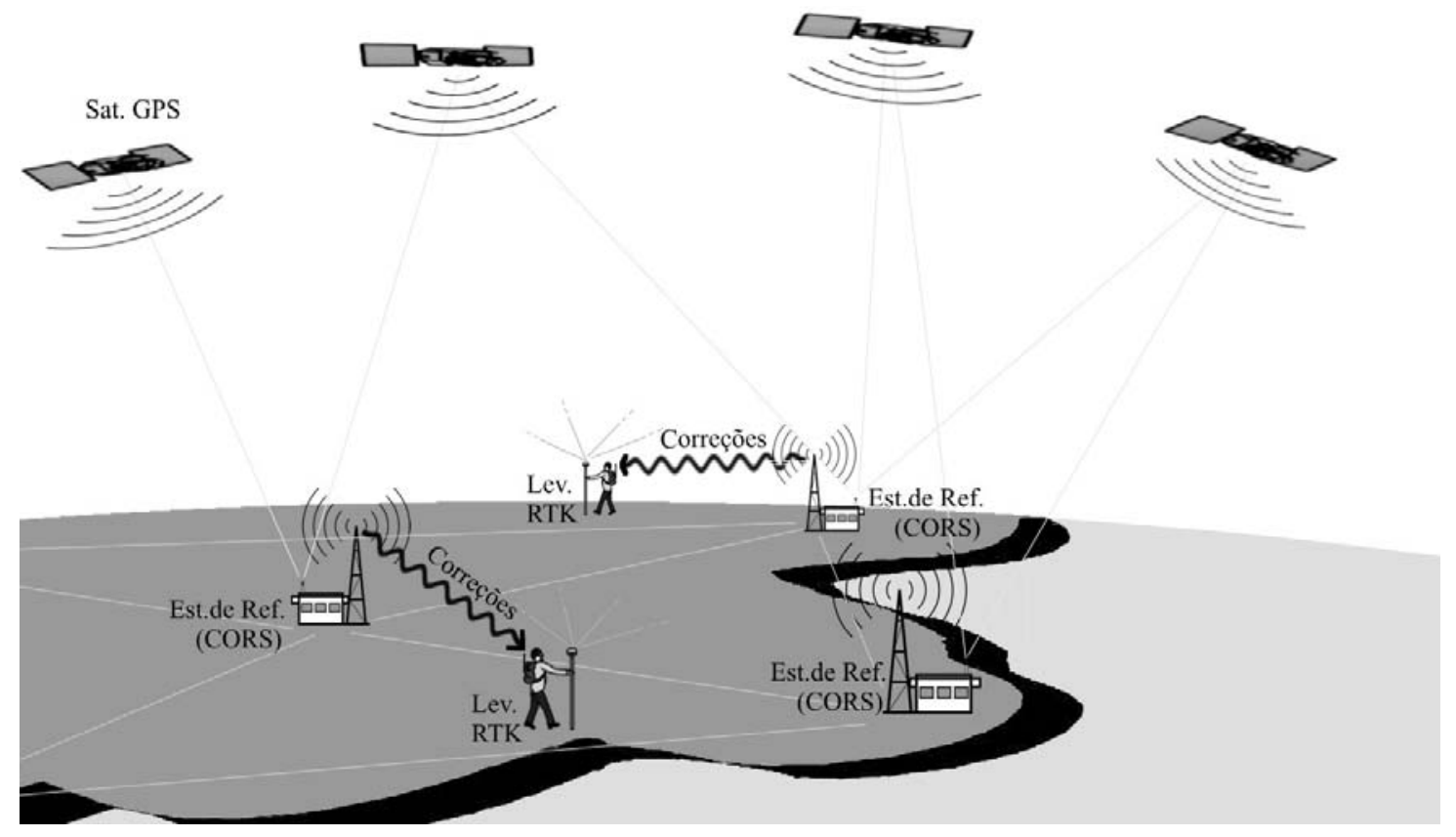

Figura 11 - RTK - Correções Via Estações de Referência

Os métodos diferenciais têm sido bastante difundidos mundialmente em razão de suas excelentes precisões alcançadas em Tempo Real, tanto quando empregado o código (ordem métrica) como quando a fase (ordem centimétrica).

A seguir são apresentadas resumidamente as principais características sobre as técnicas mais usadas nos posicionamentos relativos com GPS (Tabela 2).

Tabela 2 - Características das Técnicas de Posicionamento Relativo

\begin{tabular}{|c|c|c|c|}
\hline Técnica & Requisitos mínimos & Aplicações & Precisão \\
\hline $\begin{array}{c}\text { Estático } \\
\text { (pós-processado) }\end{array}$ & $\begin{array}{l}\bullet \text { Receptor GPS L1 ou L1/L2 } \\
\bullet \text { Observação mínima de 30min. }\end{array}$ & $\begin{array}{l}\text { (alta precisão) } \\
\bullet \text { Pontos de controle }\end{array}$ & Sub-centimétrica \\
\hline $\begin{array}{l}\text { Rápido Estático } \\
\text { (pós-processado) }\end{array}$ & $\begin{array}{l}\bullet \text { Receptor GPS L1/L2 } \\
\bullet \text { Observação de } 5 \text { a } 20 \text { min. } \\
\bullet \text { Somente ocupação simples }\end{array}$ & $\begin{array}{l}\text { (de média a alta precisão) } \\
\bullet \text { Pontos de controle }\end{array}$ & Sub-centimétrica \\
\hline $\begin{array}{c}\text { Cinemático } \\
\text { stop and go } \\
\text { (pós-processado) }\end{array}$ & $\begin{array}{l}\bullet \text { Receptor GPS L1 } \\
\bullet \text { Necessário inicialização } \\
\bullet 0,1 \text { a } 2 \text { minutos para ocupação } \\
\text { de linha base } \\
\bullet \text { Contato contínuo com os } \\
\text { satélites }\end{array}$ & $\begin{array}{l}\text { (média precisão) } \\
\bullet \text { Pontos de controle } \\
\bullet \text { Posicionamento rápido de ponto }\end{array}$ & Centimétrica \\
\hline $\begin{array}{l}\text { Cinemático - RTK } \\
\text { (tempo-real) }\end{array}$ & $\begin{array}{l}\bullet \text { Receptor GPS L1/L2 } \\
\bullet \text { Link de comunicação de dados } \\
\text { - Inicialização convencional ou } \\
\text { OTF (on the fly) em movimento } \\
\text { • Linha base inferior a } 10 \mathrm{~km} \\
\bullet \text { Manter contato com os satélites }\end{array}$ & $\begin{array}{l}\text { (média a alta precisão) } \\
\bullet \text { Locações em geral } \\
\bullet \text { Controle de tomada de fotos } \\
\bullet \text { Posicionamentos topográficos } \\
\bullet \text { Acompanhamento de construções } \\
\bullet \text { Estaqueamentos }\end{array}$ & Centimétrica \\
\hline
\end{tabular}




\subsection{7 - Seleção do equipamento GPS}

Atualmente, o mercado de equipamentos de GPS é bastante diversificado. O usuário, quando for selecionar um equipamento, deve analisar principalmente a finalidade para a qual o mesmo se destina e quanto está disposto a gastar. A partir daí, deve estabelecer as características mínimas que o equipamento precisa ter para atender sua finalidade, tais como: uma ou duas freqüência, pós-processado ou Tempo Real, limite de exatidão desejada, tipo de suprimento de energia, o ambiente operacional de coleta de dados, características e capacidade de software de pós-processamento e recursos de exportação de dados.

\section{Considerações para seleção do receptor GPS}

Os fatores importantes para a seleção de um conjunto receptor (sistema) GPS, segundo a USACE (2003), para os levantamentos topográficos e geodésicos, são as seguintes:

- Tipo de aplicação - é considerado fator preponderante, o qual define onde será empregado o equipamento. Devem ser consideradas todas as aplicações possíveis, atentando para o fato de que quanto mais aplicações, maior o custo. O potencial do receptor deve ser bem definido para evitar, por exemplo, a aquisição de um sistema GPS de US\$50.000, quando um de US\$10.000 seria suficiente.

- Exigências de precisão - é essencial para decidir o tipo de receptor necessário. É a precisão que diferencia o método de levantamento e o tipo de sinal a ser rastreado. Vale lembrar que o custo do receptor tipicamente aumenta com o aumento da precisão.

- Suprimento de energia - é também um fator importante na determinação do tipo de receptor. A autonomia de energia incluindo opções de fontes externas garante a continuidade da operação do receptor.

- Ambiente físico de operação - O ambiente físico operacional do posicionamento também é um fator importante na seleção: do tipo de antena, do dispositivo de montagem (antena e receptor), da dimensão, peso e robustez etc. Em ambientes mais severos (alta temperatura, variação de umidade, área barrenta, com poeira, etc.) deve-se optar por um receptor mais robusto. 
- Comprimento da linha de base - nos posicionamentos estáticos os comprimentos das linhas de base determinarão o tipo de receptor necessário. Receptores de uma freqüência são normalmente adequados para linhas de base menores que $20 \mathrm{~km}$ e acima disso são recomendados receptores de dupla freqüência.

- Armazenamento de dados - a forma de armazenamento dos dados pode ser interna (memória fixa ou cartões de memória removíveis) ou externa conectada a partir das portas de comunicação às unidades de armazenamento, por exemplo, um HD de computador. A capacidade de armazenamento deve ser função do projeto típico de posicionamento, considerando a taxa de coleta de dados.

- Interface com o usuário - a maioria dos receptores e controladores de dados modernos contém mostradores com ícones simples para selecionar os modos de posicionamento e as opções de armazenamento de dados. Alguns receptores apresentam advertências audíveis e visuais configuráveis conforme o evento (ex. quando a qualidade dos dados for "pobre”). Os custos variam com as opções e tamanho do LCD de exibição no receptor ou terminal.

- Canais de rastreamento de Satélites - a maioria dos receptores de qualidade tem capacidade para rastrear 12 ou mais canais em modo paralelo.

- Tempo de partida (sincronismo com satélites) - os receptores de GPS variam no tempo necessário para sincronismo. Eles possuem partida a frio (1 a 3 minutos) e partida a quente ( $<1$ minuto). Esses critérios podem ser significativos para quem trabalha em aplicações de posicionamento topográfico no modo RTK onde a perda de ciclos é comum devido a obstruções recorrentes.

- Tamanho e peso - estes fatores são importantes se os receptores forem usados para posicionamentos topográficos RTK ou trabalho de mapeamento cinemático. A maioria dos receptores portáteis geodésicos pesa entre 0,5 e 2,5 kg e os sistemas remotos RTK, incluindo todo o equipamento auxiliar, podem chegar a $3 \mathrm{~kg}$.

- Provedores de sinais DGPS - é a capacidade do receptor GPS em adquirir correções diferenciais de terceiros. Em áreas remotas ou montanhosas é importante receber códigos DGPS variados, principalmente se um dos sinais do DGPS for fraco ou não receptível. Alguns receptores DGPS podem obter correções de fontes variadas como radiofarol (Beacon) ou via satélite (Omnistar e Racal). 
- Capacidade de rastrear GLONASS - é a habilidade para adquirir e processar satélites do sistema russo GLONASS. Este fator é bastante vantajoso em áreas montanhosas ou urbanas onde os satélites NAVSTAR podem estar parcialmente bloqueados, além de proporcionar também maior precisão geométrica.

- Tipo de antena - existe uma grande variedade de antenas que podem ser utilizadas com vários receptores. Algumas são construídas em conjunto com o receptor e outras são externas. Em aplicações de posicionamento de controle estático, por exemplo, são necessárias antenas que reduzam os efeitos do multicaminhamento (são mais caras, pois incluem em suas configurações, plano terra, anéis concêntricos etc.).

- Requisitos de processamento - os procedimentos operacionais são necessários antes, durante, e depois de uma sessão de observação, dependem do fabricante e devem ser considerados (e testados) antes da compra do receptor. Normalmente um receptor pode ser fácil de operar no campo (requer pouca intervenção do usuário), mas pode necessitar mais tempo e esforço (depois do posicionamento) para descarregar e processar os dados (i.e. o software de pós-processamento pode ser pouco amigável).

- Custo - é um dos fatores mais importantes e que determinam o tipo de receptor que se pode comprar. O custo do receptor (hardware e software) é função dos custos de desenvolvimento, competição entre fabricantes e demanda do produto. Historicamente os custos de um equipamento de GPS sempre foram elevados, mas se comparados com os valores de hoje mostram-se em uma contínua e significativa diminuição.

- Formato para troca de dados - é importante que a transferência de dados seja feita em um formato convencional. Os fabricantes de GPS normalmente têm os seus próprios formatos de dados, porém, a maioria permite exportar os dados em um formato de texto comum, como o formato internacional RINEX (Receiver Independent Exchange) usado para pós-processar os dados. No caso dos equipamentos para levantamentos em Tempo Real é importante considerar também o formato das correções enviadas pela base e as recebidas pelo receptor usado. Normalmente, além dos formatos proprietários, os fabricantes disponibilizam correções no formato RTCM SC-104 que é um padrão convencional. 
Além do formato dos dados, pode ser interessante considerar a capacidade do receptor em gerar informações da posição no formato NMEA 0183 e a capacidade do sistema para exportar os resultados pós-processados ou Tempo Real nos formatos ASCII, DXF, DGN e outros.

Outro ponto importante diz respeito à avaliação completa do conjunto do equipamento antes de fechar o negócio (incontestavelmente) incluindo também os equipamentos auxiliares. Nesse caso, devem ser usados e testados exemplos típicos reais em todas as etapas (montagem, posicionamento, processamento e relatório final etc.) para ter certeza de que o equipamento escolhido atende às necessidades pré-definidas com satisfação. Todo o processo deve ser acompanhado pelo usuário ou pessoal técnico competente que assegure total transparência e garantia de satisfação.

As facilidades relacionadas ao fabricante também devem ser consideradas, tais como: garantias, manutenção e treinamento, assistência técnica facilitada, reconhecimento técnico, certificação de qualidade e outros.

\subsection{8 - Geração de relatórios GPS}

Os relatórios finais compreendem uma série de itens que dependem exclusivamente das exigências dos contratantes para cada serviço. A maioria dos softwares de processamento oferece possibilidade de configurações do relatório, que, muitas vezes, são usados em modo padrão (default), apresentando ou omitindo informações importantes. A regra básica é adotar o padrão exigido pelo contratante ou na ausência apresentar um relatório simples que forneça condições plenas para interpretar e analisar claramente os resultados do serviço executado.

Um relatório deve ser apresentado na forma técnica, ser abrangente e ter clareza. O Corpo de Engenheiros dos EUA, (USACE, 2003) recomenda, por exemplo, as seguintes seções:

\section{Seção 1: Descrição do Projeto Geral}

Informações do projeto incluindo localização, propósito e partes envolvidas. 


\section{Seção 2: Fundamentação}

Razão para o projeto (descrição mais detalhada) e descrição mais específica do local, incluindo um mapa. Também devem ser discutidos nesta seção os níveis de precisões e os prazos de entrega.

\section{Seção 3: Planejamento do projeto}

O projeto foi planejado incluindo, mas não se limitando: resultados do reconhecimento; ferramentas de disponibilidade de satélite e GDOP usados; métodos (GPS/DGPS) selecionados; características e atributos padrões selecionados.

\section{Seção 4: Coleta de dados}

Avaliação de como os dados foram coletados incluindo, mas não se limitando a:

- equipamentos usados (marca e modelo);

- métodos e/ou técnicas de coleta usados;

- pontos de controle usados (breve histórico de controle, datums e observações da conservação);

- quantia de dados coletados;

- número de equipes e pessoal por equipe;

- quanto tempo levou a coleta de dados;

- dados processados e erros conferidos executados no campo.

\section{Seção 5: Processamento de dados}

Como foi feito o processamento dos dados incluindo, mas não se limitando aos seguintes processos.

\section{Subseção 5.1: Processamento de linha base:}

Software usado; resultados do processamento das linhas de base (resumo); argumentos para o re-processamento de linhas de base; parâmetros para o processamento de linha base (máscara de elevação, tipo de efemérides usadas); resumos dos resultados ou fechamentos de figuras (se aplicável).

\section{Subseção 5.2: Ajustamento de Redes:}

Software usado; resultado do ajustamento livre com o mínimo de injunção (comparar as coordenadas do ponto conhecido com as obtidas), e o ajustamento completo que considere todas as injunções; resumo dos pesos usados e estatísticas gerais. 


\section{Seção 6: Resumo do projeto e Conclusão}

Esta seção deve incluir uma narrativa dos resultados globais do processo, produtos produzidos, listagem dos elementos submetidos, precisão global da coleta de dados (baseada nos resultados da seção de processamento dos dados), problemas encontrados durante a coleta e o processamento dos dados, recomendações para futuras coletas de dados do mesmo tipo ou na mesma área (lições aprendidas).

\section{Seção 7: Arquivos e Relatórios de Software gerados}

Esta seção deve incluir os relatórios detalhados e os arquivos produzidos pelos pacotes de softwares aplicativos usados durante o processamento dos dados, pode ter subseções múltiplas, por exemplo, uma para cada passo dos processos que produziram os arquivos. Isso é fundamental para uma análise crítica na avaliação dos resultados.

\section{2 - ESPECIFICAÇÕES E NORMAS PARA GPS}

As especificações, normas e instruções de posicionamentos com GPS são regras básicas definidas com critérios mínimos de execução e aceitabilidade, normalmente adaptadas por cada país (governo) às suas necessidades. Essas regras exigem normalmente procedimentos especiais tanto de campo como de escritório, a fim de garantir a qualidade nos resultados.

As regras definem como os padrões podem ser atingidos, e envolvem o planejamento, o projeto, a instrumentação, os procedimentos de campo e escritório, os critérios de aceitação e elaboração de resultados, de modo que promovam eficiência (e confiabilidade) ao processo. Os padrões, por sua vez, especificam os graus de exatidão (acurácia) obtidos no posicionamento absoluto ou relativo.

As normas de posicionamento com GPS normalmente usam o princípio de qualidade e precisão em função do comprimento da linha de base. Existem normas que consideram o princípio da vizinhança, em que a precisão de um ponto levantado na região onde existe uma rede de pontos de controle vizinhos é obtida a partir da precisão da rede existente. Em geral, as especificações têm a forma de exigências rígidas, recomendações ou simples sugestões. 
A tecnologia envolvida no sistema GPS está em constante melhoria (novas técnicas e modificações), mas exige também atualizações constantes das regras que regulamentam sua aplicação. A primeira organização geodésica a preparar padrões e especificações para posicionamentos com GPS foi o U.S. National Geodetic Survey, por meio do Federal Geodetic Control Committee - FGCC (1988). Essas regras são pioneiras e têm sido adotadas em muitos outros países, com modificações secundárias feitas para atender os diferentes padrões de precisão de posicionamentos.

No Brasil, há uma carência tanto de normas e instruções oficiais quanto de material (livros técnicos e manuais) em português. Uma razoável quantidade de material pode ser obtida em artigos de congressos e em teses e dissertações, embora seja difícil o acesso a esse material para quem não pertence ao meio acadêmico. Atualmente o material oficial existente (disponível e divulgado) sobre GPS consta de duas publicações, uma do IBGE - Instituto Brasileiro de Geografia e Estatística (IBGE, 1992) e outra feita pelo INCRA Instituto Nacional de Colonização e Reforma Agrária (INCRA, 2003).

\subsection{1 - Normas NACIONAIS}

\section{IBGE}

A norma do IBGE intitulada de Especificações e Normas Gerais para Levantamentos GPS (Preliminar) descreve todo o sistema GPS e apresenta conceitos sobre os elementos principais do sistema tais como:

- códigos e portadoras;

- tipos de observação;

- classificação e aplicações;

- equipamentos e técnicas de posicionamento;

- geometria de rede;

- observações de campo;

- processamento e,

- modelos de formulários para documentação do posicionamento.

Esse material, por ser pioneiro, é bastante consultado e abrange quase todos os aspectos de um posicionamento, porém, com os avanços tecnológicos do sistema tornou-se 
desatualizado, principalmente com relação aos novos métodos de posicionamento rápidos e cinemáticos e também à ausência de informações claras sobre ajustamentos e análises de erros (precisão e exatidão).

\section{INCRA}

O material disponibilizado pelo INCRA, denominado de Normas Técnicas para Georreferenciamento de Imóveis Rurais, não trata especificamente só de posicionamento com GPS, inclui também os serviços topográficos convencionais. Trata-se de uma nova norma do INCRA que contém trechos de normas anteriores, onde foram incluídos tópicos relacionados à integração com Sistema de Informações Geográficas (SIGs) e instruções sobre técnicas de posicionamentos com GPS voltadas às exigências do órgão para cadastramento de imóveis rurais.

O propósito principal da norma é orientar os profissionais que atuam no mercado de demarcação, medição e georreferenciamento de imóveis rurais para atender a lei 10.267/01, contendo basicamente os seguintes tópicos:

- classificação para posicionamentos quanto aos padrões de precisão e exatidão;

- informações sobre habilitação de profissionais e documentação do posicionamento;

- características de monumentação;

- informações sobre o sistema cartográfico nacional;

- métodos de posicionamento para apoio básico (convencionais e por GPS);

- métodos de posicionamento altimétrico e perimétrico (convencional e por GPS);

- ajustamento e avaliação dos resultados;

- apresentação dos trabalhos e

- modelos de formulários para documentação do serviço.

Nessa norma, as técnicas de posicionamentos com GPS são classificadas com as siglas:

- GPS1 (para navegação) não admitida;

- GPS2 (posicionamento diferencial baseado em códigos com correções em Tempo Real e DGPS corrigidos via satélite) não admitida;

- GPS3 (posicionamento por código e fase da portadora e pós-processado),

- GPS4 (posicionamento cinemático pós-processado e Tempo Real - RTK) 
Essa norma é a mais recente, e por isso engloba as principais características e técnicas de posicionamento GPS atualmente existentes. Com isso proporciona apoio básico aos prestadores de serviços de georreferenciamento dos imóveis rurais no Brasil.

\subsection{2 - Normas INTERNACIONAIS}

As normas, instruções e especificações para posicionamentos com GPS de origem internacional são geralmente específicas e destinam-se a levantamentos de redes de controle geodésico e apoio a projetos de engenharia e cadastro. Entre as normas internacionais existentes, aqui são abordadas as seguintes:

- Geospatial Positioning Accuracy Standard do Federal Geographic Data Committee - FGDC, USA;

- Geometric Geodetic Accuracy Standards and Specifications for using GPS Relative Positioning Technique do Federal Geodetic Control Committee - FGCC, USA,

- Standards and Practices for Control Surveys (SP1) do Inter-Governmental Advisory Committee on Surveying and Mapping - ICSM, Australia

As normas “Geospatial Positioning Accuracy Standard” (FGDC, 1998) são do tipo genérico para padrões de precisões de posicionamento geoespacial, sem especificar métodos e equipamentos. São divididas em 5 partes:

1. relatório da metodologia;

2. padrões para redes geodésicas;

3. padrões nacionais para exatidão de dados espaciais;

4. padrões para arquitetura, engenharia, construção e projetos de gerenciamento de recursos naturais,

5. cartas de navegação e levantamentos hidrográficos.

Essas normas contêm também em anexo, na parte 1, um glossário com várias definições e conceitos importantes tanto para análise como para aceitação de trabalhos contratados.

A norma "Geometric Geodetic Accuracy Standards and Specifications for using GPS Relative Positioning Technique” (FGCC, 1988) é uma das mais antigas e continua em uso nos EUA em conjunto com outras. Seu enfoque principal baseia-se na 
classificação de padrões e precisão de posicionamento para o método de posicionamento estático (únicos confiáveis na época de sua elaboração). Apresenta as seguintes especificações:

- projeto de redes, geometria e conexões à rede nacional americana com exigências rigorosas para o uso de linhas de base independentes, fechamento de circuitos e nível de confiança de 95\% para todas medições uni e tridimensional.

- equipamentos necessários;

- testes e calibração;

- procedimentos de campo e de escritório,

- tabelas resumidas com notas técnicas e materiais.

Para solução de um posicionamento com GPS essa norma considera dois aspectos:

- a necessidade de ajustamento de redes tridimensionais pelos mínimos quadrados e,

- o ajustamento do posicionamento com GPS em duas classes:

o uma de consistência interna que independem do controle de rede externa e ajustada apenas com uma estação fixa (injunções mínimas ou livres) e,

o outra com conexões a uma rede de controle externa. (fixas ou injuncionadas por pesos).

A norma "Standards and Practices for Control Surveys (SP1)” (ICSM, 2002) é uma norma para posicionamentos topográficos e geodésicos em geral, incluindo o GPS com atualizações freqüentes. Apresenta um glossário de termos técnicos e foi dividida em quatro partes:

Parte A: Padrões de exatidão;

Parte B: Procedimentos recomendados para calculo e posicionamento;

Parte C: Monumentação e sinalizações recomendadas para os pontos; e

Parte D: Documentações recomendadas

A parte A define padrões de classes e ordens para controle de posicionamentos horizontais e verticais, incerteza posicional e local e regiões de confiança.

A parte $\mathbf{B}$ trata dos procedimentos de posicionamentos em geral, incluindo o posicionamento com GPS contendo: 
- planejamento do posicionamento;

- métodos de posicionamento clássicos e atuais (stop and go, rápido estático, RTK);

- processamento de linhas de base;

- ajustamentos e análise (mínimos quadrados e fechamento de poligonais) e,

- avaliação de resultados

Nessa parte inclui ainda projeto e ajustamento de redes e transformações de datum.

A parte $\mathbf{C}$ informa as características desejáveis para a monumentação das estações.

A parte D apresenta a descrição dos elementos necessários (documentação) que serão coletados e registrados nos posicionamentos (horizontal e vertical) para uso em um sistema de informação (banco de dados), forma de arquivamento dos dados incluindo os dos posicionamentos com GPS.

A maioria dessas normas tem como origem a experiência técnica (de campo e de escritório), tanto de GPS como das técnicas convencionais clássicas, desenvolvidas pelos muitos profissionais que contribuíram para o desenvolvimento das especificações presentes, embora sempre paire a dúvida (não esclarecido) de como se chegou aos valores especificados (suposição, experiência ou fato científico).

Com relação ao posicionamento com GPS (sistema em constante melhoria) é extremamente necessário que as especificações sofram avaliação e refinamento contínuo de acordo com a evolução do sistema, e que garanta a qualidade do processo e a satisfação dos usuários.

Verifica-se no material analisado que a maioria das normas apresenta observações sobre as exigências mínimas necessárias para um posicionamento com GPS. Outras mais recentes relatam o que deve ser feito e algumas até sobre como deve ser feito, porém, em todas elas, nenhuma trata dos fatores relacionados às rotinas e procedimentos básicos que considere desde o pedido (contratação) passando pelas etapas do processo (viabilidade, análise e elaboração do projeto, execução, armazenamento) até a entrega dos resultados. 
Em outras palavras, não há uma norma ou especificação que trate com maior clareza as necessidades do uso de um Sistema da Qualidade como papel fundamental de reconhecimento pela prestação de serviços de posicionamento com GPS de qualidade. Segundo Marques et. al (2004), as empresas de serviços com GPS consideram que informações sobre a Gestão da Qualidade no setor de posicionamentos são de grande importância, pois norteariam suas ações, e forneceriam meios para controlar e garantir a qualidade de seus produtos e serviços. Assim sendo, os principais beneficiários seriam os clientes que passariam a ser mais bem esclarecidos antes de contratar um serviço e poderiam, se desejassem, controlar a qualidade das etapas de serviços. 


\section{3 - OS SERVIÇOS COM GPS}

Atualmente quase todas as empresas ou organismos que prestam serviços relacionados a algum tipo de medição de distância, área ou volume envolvendo a superfície terrestre ou em suas proximidades, adotam o GPS como ferramenta para garantir produtividade e qualidade dos serviços.

O sistema GPS tem proporcionado padrões de precisão e confiabilidade aos resultados de posicionamentos topográficos e geodésicos bastante expressivos, se comparados com os chamados métodos clássicos. Este fato tem levado os prestadores desses tipos de serviço a investir mais em tecnologia, treinamento e qualificação de pessoal para atender um mercado cada vez mais exigente e competitivo.

\section{1 - TIPOS DE ORGANIZAÇÕES}

O mercado de prestadores de serviços de posicionamentos com GPS no Brasil apresenta característica funcional bastante variada, que consiste em escritórios de engenharia de pequeno e médio porte, setores ou departamentos vinculados a alguma grande construtora, mineradora, instituições de pesquisa, órgãos públicos da união de governos e municípios e ainda profissionais autônomos que atuam no mercado informal.

Embora seja grande o contingente de profissionais e empresas que prestam serviços com GPS, há uma ausência de dados estatísticos e informações mais específicas sobre a situação do setor. Após a realização de uma pesquisa independente com uma amostra de prestadores de serviços GPS no Brasil, constatou-se que os pequenos escritórios e os diversos setores e departamentos que trabalham com GPS possuem características semelhantes. Assim sendo, decidiu-se adotar neste trabalho um modelo genérico, que pudesse representá-los como um grupo único. 


\section{2 - O PRODUTO BASE}

A prestação de um serviço está submetida a um conjunto de características próprias, que a torna diferente de uma mercadoria comum. Suas características são, por exemplo:

- intangíveis (não podem ser experimentados antes da compra);

- inseparáveis (requerem a participação de quem produz e de quem consome, durante o processo de produção);

- variáveis (cada caso é único, sendo muito mais difícil padronizar o processo produtivo, embora não impossível);

- não armazenáveis (não podem ser estocados nem produzidos antecipadamente);

- desprotegidos (os processos de produção podem ser copiados livremente pela concorrência) e

- de preços diferenciados (em um mesmo mercado, serviços semelhantes apresentam variações de preços surpreendentes).

Além de todas essas características que valem para todos os tipos de serviços, os serviços de posicionamento com GPS ainda apresentam outras duas muito particulares e importantes:

- são produtos de consumo restrito, ou seja, não são produtos de consumo de massa, e seu processo de negociação não pode seguir os padrões dos produtos de consumo de massa;

- são produtos com alto componente intelectual agregado, ou seja, existe normalmente uma lacuna de entendimento, de percepção do produto, entre a visão do cliente e a do engenheiro.

Assim sendo, acredita-se ser bastante difícil conseguir produzir, divulgar, negociar e vender SERVIÇOS utilizando os mesmos conhecimentos e as mesmas técnicas e práticas que funcionam para produzir, divulgar, negociar e vender MERCADORIAS.

O produto base do serviço de posicionamento com GPS são números, ou seja, são valores de coordenadas bi ou tridimensionais que servirão para as mais variadas aplicações desde o estabelecimento de um ponto até a análise do deslocamento de uma estrutura de engenharia civil. 
Normalmente o produto de um posicionamento com GPS é usado para a obtenção de algum outro tipo de produto, por exemplo, a determinação da posição e a localização de um elemento, a confecção de um mapa, a elaboração do traçado de uma via, a determinação de uma rota de exploração e vôo, o cálculo de uma superfície ou de um volume etc. $\mathrm{O}$ resultado final de qualquer um desses elementos depende primordialmente da qualidade dos resultados do processo de posicionamentos usado para sua confecção que, no caso deste trabalho, é o GPS.

\section{3 - PRINCIPAIS CLIENTES}

Conforme comentado anteriormente, devido à variedade de aplicações dos resultados de posicionamentos com GPS, são vários os clientes do produto desse serviço. Entre eles vale a pena citar os setores e departamentos de empresas e organizações governamentais e privadas onde atuam engenheiros das mais diversas áreas, tais como: construção civil, agrimensura, cartografia, naval, geologia, arquitetura, agronomia, telecomunicação etc.

\section{4 - EMPRESA GENÉRICA}

Para ilustrar o desenvolvimento da proposta desta tese foi elaborada (adotada) uma empresa genérica com características similares a maioria das empresas prestadoras de serviços com GPS. A elaboração baseou-se em informações coletadas na pesquisa social realizada com empresas do ramo (Apêndice B), algumas visitas a instalações de empresas próximas do local da pesquisa e a partir de informações coletadas no site do SEBRAE na internet.

\subsection{1 - Características básicas}

A empresa genérica foi denominada de GPSAT (nome fantasia) e apresenta as seguintes características:

- classificação tributária: Pequena Empresa;

- ramo de atuação: Prestação de serviços;

- serviços prestados: posicionamentos de pontos com GPS para topografia (planimetria, altimetria e cadastro); geodésia; Sistemas de Informações Geográficas; Apoio a Fotogrametria; obras civis e assessoria técnica; 
- estrutura física: escritório contendo as seguintes dependências: salão de recepção e atendimento; administração e direção; sala de equipamentos; sala de engenharia e projetos; arquivo técnico; e dependências básicas (convivência, sanitários, manutenção e limpeza);

- equipamentos: Todos próprios registrados e devidamente calibrados e certificados em conformidade com as especificações:

o para campo: dois automóveis, um par de receptores GPS; uma estação total, um nível automático, um computador portátil e acessórios,

o no escritório: um automóvel, cinco microcomputadores, programas aplicativos, traçadores gráficos (impressora / plotter), um scanner, e acessórios.

- recursos humanos: O quadro de funcionários apresenta regime de dedicação integral: dois profissionais de nível superior, habilitados como responsáveis técnicos da empresa junto ao CREA (sócio/diretor); um profissional técnico de nível médio; dois auxiliares; uma secretária e outros recrutados em caráter temporário (campo);

- principais fornecedores: órgãos públicos e privados, instituições de pesquisa, bancos, jornais e revistas, escritório de assessoria contábil e jurídica, prestadores de serviços, provedores de internet, empresas vendedoras de equipamentos;

- histórico da qualidade: nenhum projeto realizado,

- motivação: implantação de um Sistema da Qualidade para melhorar a gestão e o controle das operações com vistas à certificação.

Os documentos da qualidade da empresa GPSAT (elaborados e considerados) são apresentados no item 6.4.2.

\section{5 - CICLO DE VIDA DO SERVIÇO COM GPS}

O ciclo de vida de um posicionamento com GPS tem características próprias, sendo composto geralmente pelas seguintes fases (Figura 12): preparação e planejamento; operações de campo; processamento de dados e relatório final. Esta é uma seqüência básica recomendada pelas principais normas nacionais e internacionais de posicionamento com GPS. 


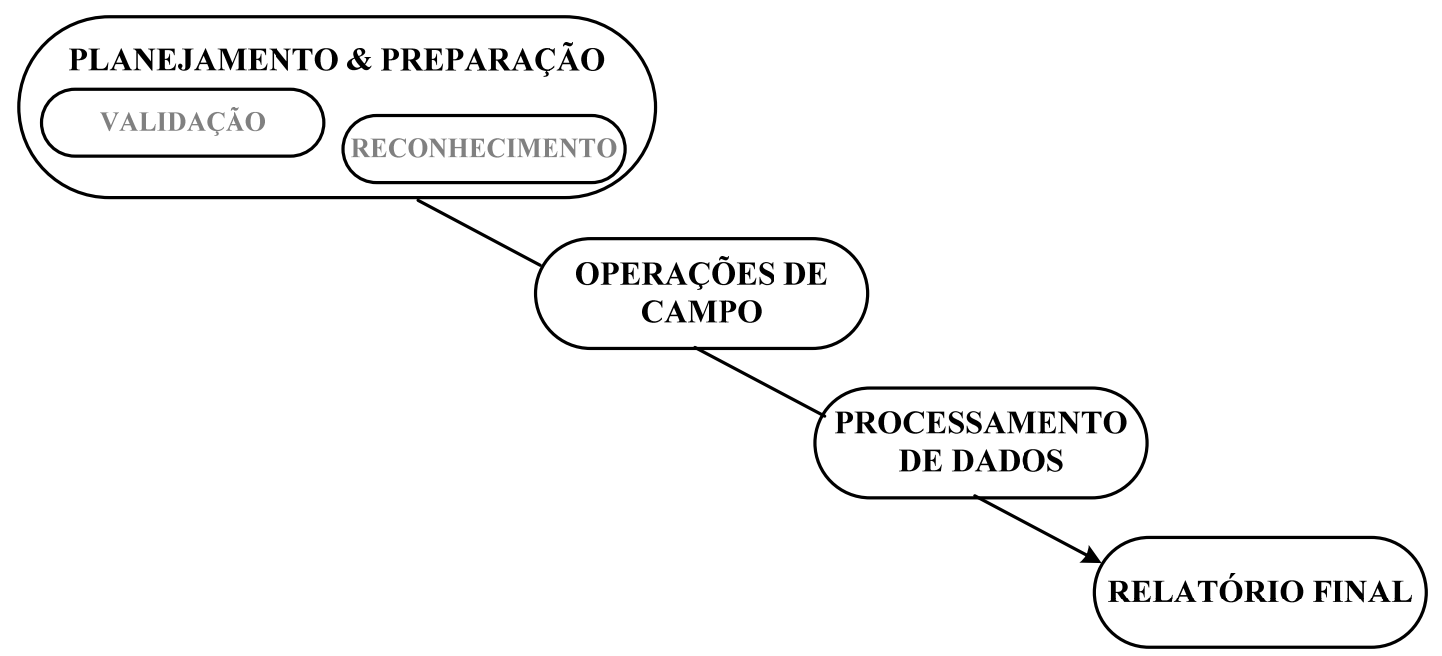

Figura 12 - Etapas de um posicionamento genérico com GPS

\subsection{1 - Fase de Preparação e Planejamento}

A fase de preparação e planejamento de campo para um projeto de GPS começa com a identificação dos requisitos do posicionamento e termina com a definição completa das operações de campo. A extensão das etapas intermediárias varia de acordo com o tamanho, precisão e localização do projeto. Como etapa preliminar, deve-se obter informações sobre a disponibilidade de pontos de controle na região, identificar suas posições e as exigências de precisão para possíveis ocupações (obtidos em mapas e relatórios de órgãos públicos e/ou privados). Os prováveis locais a serem levantados e os pontos de controle disponíveis devem ser marcados em um mapa, em escala adequada. Para este propósito as normas sugerem as escalas 1:10.000, 1:50.000 e 1:100.000. Os mapas de estradas (municipal e estadual) também são muito úteis para determinar as distâncias aproximadas entre os pontos, informações de acesso ao local, e o provável potencial de obstruções e interferências.

Entre os passos mais importantes dessa fase de planejamento e preparação incluem-se:

a) seleção do método de posicionamento

b) seleção do tipo de receptor;

c) validação de técnicas e procedimentos;

d) reconhecimento de campo;

e) projeto do posicionamento; e,

f) preparação do posicionamento.

De um modo geral esses passos são interdependentes e estão sintetizados a seguir. 


\section{a) Seleção do método de posicionamento}

Entre os principais aspectos que influenciam a escolha do método de posicionamento têm-se: as exigências de precisão, o ambiente geográfico, a distância entre os pontos a serem posicionados e os custos envolvidos.

Para escolha da técnica de posicionamento mais adequada, a sugestão comum das principais normas de posicionamento com GPS (nacional e internacional) é função da acurácia horizontal (desejada) conforme o caso. Um exemplo da classificação dos principais métodos que podem ser usados em função dos valores aproximados para uma determinada acurácia horizontal proporcionada é mostrado na Figura 13. Para o caso da precisão vertical os valores correspondem ao dobro dos valores obtidos para a acurácia horizontal.

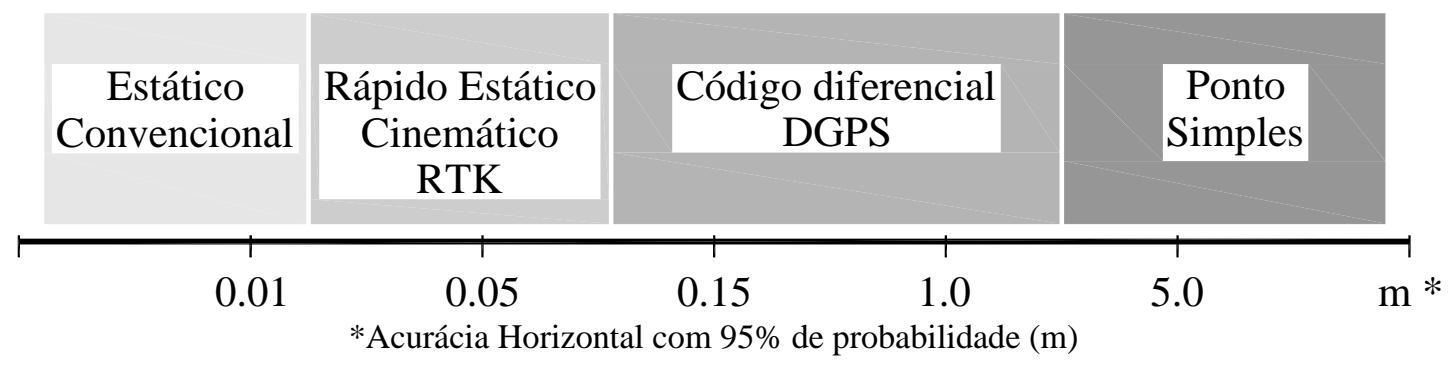

Figura 13 - Métodos de posicionamento com GPS e suas precisões

O custo do posicionamento com GPS é outro fator fortemente influenciado pelo método usado, pois depende principalmente das exigências de acurácia do produto. Entre as razões para variações de custo com o método empregado, duas são indiscutíveis: o tempo de rastreio necessário no local e o custo dos receptores empregados. Dessa forma, um menor tempo de rastreio no local implica em um custo de posicionamento mais baixo.

\section{b) Seleção do tipo de receptor}

Os receptores de GPS de uma empresa podem ser alugados, comprados ou arrendados, porém, em qualquer caso, a sugestão unânime das normas é que todos os receptores usados no posicionamento relativo sejam do mesmo fabricante para evitar problemas com o resultado, tais como: erros sistemáticos, complexidades no processamento e incompatibilidade de taxa de gravação de dados. 
No item 2.1.7 foram apresentados algumas considerações importantes para escolha do melhor conjunto de equipamentos (hardware e software). A norma canadense GPS Positioning Guide (NRC, 1995) lista vários elementos que podem ser considerados na seleção de um receptor GPS (Figura 14), porém não devem ser usados como única regra, pois a intenção é apenas direcionar o planejamento, e naturalmente as prioridades para cada aspecto sofrerão variações dependendo da aplicação desejada.

\section{Considerações Técnicas}

- Tipo de medida coletada

- Simples ou Dupla freqüência

- Método usado para coletar a fase de L2

- Número de canais

- Tipo de antena e características de ruído

- Acurácia das medidas do código / fase

\section{Características de campo}

- Peso

- Tamanho

- Robustez

- Temperatura de operação

- Fontes de alimentação

- Acessórios
Operações do receptor

- Fácil de usar

- Planejamento de aplicações

- Monitoramento do rastreio

- Facilidade para entrada de dados

Considerações empresariais

- Custo

- Garantia

- Manutenção e Suporte técnico

\section{Registro de dados}

- Tipo de memória (interna ou cartão)

- Capacidade de armazenamento

- Taxa de gravação

\section{Software acompanhante}

- Predição de satélites

- Capacidade de descarregamento de dados

- Formatos de importação e exportação

- Opções de pós-processamento

Figura 14 - Aspectos a serem considerados na escolha de um receptor GPS

\section{c) Processo de Validação}

Os procedimentos e equipamentos de coleta de dados, que serão usados para obtenção do produto final, devem ser testados, para assegurar que satisfaçam as exigências de acurácia esperadas. Esta prova é chamada de processo de validação, e no caso de serem usados os mesmos procedimentos e equipamentos de GPS de uma aplicação de êxito anterior à revalidação pode ser desnecessária.

No processo de validação três componentes principais são testados: a técnica de posicionamento escolhida, o equipamento a ser usado e o método de processamento adotado. O método de posicionamento escolhido deve ser conferido para garantir que satisfará as exigências do serviço. No caso do equipamento GPS usado, há forte variação em complexidade, custo e capacidades. Assim sendo, não se deve assumir 
plenamente que todas as informações de precisão dadas pelo fabricante do equipamento ou por outros usuários serão consistentemente obtidas em todas as condições de produção de campo. Em outras palavras, é de extrema importância testar e avaliar o equipamento antes do uso e, pelas mesmas razões, é também importante um teste que avalie o software e as técnicas de processamento GPS.

Outro benefício importante do processo de validação é permitir que sejam identificados e resolvidos os problemas antecipadamente. Começa com o posicionamento dos custos de produção, a identificação dos meios para agilizar as operações e a verificação das precisões que podem ser alcançadas usando os procedimentos testados. O conceito de validação é resumido na Figura 15.

\section{CONCEITO DE VALIDAÇÃO}

Testar todos os procedimentos, da coleta de dados ao processamento final, usando pontos de controle conhecidos com acurácia superior.

\section{TESTES}

- Métodos de posicionamento com GPS

- Equipamentos

- Técnicas de processamento

\section{BENEFÍCIOS}

- Identificar e resolver problemas

- Agilizar operações

- Determinar a acurácia esperada

\section{Figura 15 - Conceito de Validação}

Os testes de validação devem ser feitos usando pontos de controle com coordenadas conhecidas e com precisão superior à desejada para o projeto. A distância entre os pontos deve ser equivalente ao projetado para execução do posicionamento.

A validação é uma etapa chave de avaliação, considerada muito importante, pois, junto com o reconhecimento de campo, forma o par fundamental para um excelente planejamento do projeto.

\section{d) Reconhecimento de campo}

A etapa de reconhecimento consiste em verificar no campo os locais de projeto antes de começar as observações com GPS. O reconhecimento do local envolve verificações de conveniência para o posicionamento com GPS, a disponibilidade de pontos de controle nas proximidades e as exigências de logística. Os componentes fundamentais de um reconhecimento de campo são apresentados resumidamente na Tabela 3. 
Tabela 3 - Componentes de um reconhecimento de campo

\begin{tabular}{c|l}
\hline Etapa & \multicolumn{1}{c}{ Situação } \\
\hline Verificar a conveniência para & - Livre de obstruções? \\
GPS & $\bullet$ Livre de interferências? \\
\hline Verificar pontos de controle & $\bullet$ Estações localizadas? \\
\hline \multirow{2}{*}{ Identificar as necessidades } & - Monumentos em condições estáveis? \\
\hline logísticas & - Métodos de transportes? \\
& $\bullet$ Equipamentos ou procedimentos especiais \\
\hline & $\bullet$ Escolher locais alternativos, se necessário \\
& $\bullet$ Estabelecer estações excêntricas, se necessário \\
\hline Entrar em ação & $\bullet$ Anotar os resultados \\
& $\bullet$ Atualizar as descrições, se necessário \\
\hline
\end{tabular}

Um bom local para posicionar o GPS deve ser livre de obstruções e interferências e de fácil acesso. As obstruções são obstáculos que bloqueiam a linha de visão entre o satélite e o receptor, prejudicando a recepção do sinal. As interferências são perturbações provocadas nos sinais de GPS que degradam a qualidade e as precisões obtidas com GPS e podem ter a forma de multicaminhamento ou interferência elétrica.

Com a etapa de reconhecimento de campo, as obstruções e/ou interferências são identificadas e evitadas, por exemplo, com a indicação de um local alternativo ou estabelecendo estações excêntricas. Para evitar o bloqueio dos satélites recomenda-se escolher um local sem obstruções em todas as direções e sobre um ângulo de elevação de $15^{\circ}$. Caso existam obstruções em condições normais, o posicionamento poderá ser possível se um número suficiente de satélites com adequada geometria puder ser observado. Tanto para os posicionamentos que usam observações da fase da portadora como para os que usam observações do código, devem ser escolhidos locais livres de obstrução. As técnicas de posicionamento do código são geralmente mais tolerantes que as técnicas da portadora, com relação às obstruções, desde que não estejam sujeitas a perda de ciclo. 
O ângulo de elevação de obstruções deve ser considerado com relação à altura proposta para a antena e não para o nível do chão (normalmente uma antena em um tripé tem altura variando entre 1,2 e 1,8 metros). A interferência de multicaminhamento pode ser reduzida, evitando locais próximos a estruturas artificiais, superfícies refletivas e, em particular, os objetos metálicos. As fontes potenciais de interferência elétrica incluem estações com transmissões em microondas, repetidoras de rádio e fios de alta tensão.

Durante a etapa de reconhecimento de campo, as estações de controle existentes e que foram planejadas para o uso devem ser conferidas “in-loco” para assegurar que possam ser encontradas em condições estáveis para satisfazerem as ocupações previstas na campanha de observações de GPS. Se na área de interesse não houver pontos de controle de apoio ou estação de monitoramento contínuo diferencial, poderá ser necessário estabelecer um novo ponto por meio de um posicionamento GPS estático convencional, usando pontos de controle da área circunvizinha.

A etapa de reconhecimento também providencia informações necessárias para a programação de apoio logístico. Em um posicionamento a escolha do método de transporte e o tempo de deslocamento para cada ponto têm implicações significativas sobre o custo e a logística do posicionamento. Da mesma forma, qualquer restrição que possa ser identificada facilitará o sucesso do planejamento, por exemplo: avaliação das vantagens de um posicionamento cinemático ou rápido estático, a necessidade de estruturas mais rígidas ou mais altas para montar a antena, a necessidade de precauções de segurança para determinados locais, entre outras. O produto final da etapa de reconhecimento de campo inclui uma série de pontos prontos para serem observados com o GPS, assim como uma descrição detalhada para cada local, informações de acesso e descrições de qualquer outra providência especial que precise ser tomada.

\section{e) Projeto do posicionamento}

Outra etapa importante na fase de planejamento e preparação é a elaboração do projeto do posicionamento. As considerações principais do projeto de posicionamento incluem as exigências de controle e a configuração de rede e redundância. Obviamente o projeto de um posicionamento pode variar extensamente, dependendo da acurácia buscada e do método de posicionamento GPS empregado. Um resumo das exigências de controle e configuração de rede conforme o tipo de posicionamento GPS é mostrado na Tabela 4. 
Tabela 4 - Tipos de controle e configuração de rede GPS

\begin{tabular}{c|c|c}
\hline Método & Tipo de controle & Configuração de Rede \\
\hline $\begin{array}{c}\text { Ponto Simples } \\
\text { (Absoluto) }\end{array}$ & Nenhum & Não Aplicável \\
\hline $\begin{array}{c}\text { Rápido Estático e } \\
\text { Cinemáticos } \\
\text { (Relativo) }\end{array}$ & No mínimo 1 ponto 3D & Radial / variada \\
\hline $\begin{array}{c}\text { Estático Convencional } \\
\text { (Relativo) }\end{array}$ & $\begin{array}{c}2 \text { ou mais pontos 3D } \\
\text { (ou equivalente) }\end{array}$ & Figura geométrica fechada \\
\hline
\end{tabular}

No posicionamento por ponto simples não são exigidos pontos de controle, pois, como este tipo de posicionamento é absoluto, não se aplica a configuração de rede e somente um receptor é necessário. No posicionamento relativo torna-se necessário pelo menos uma estação de controle tridimensional. Este ponto de controle deve ter coordenadas e altura elipsoidal determinadas no Datum oficial do local. Em geral, um posicionamento relativo típico assume um padrão de rede radial conforme ilustrado na Figura 16.

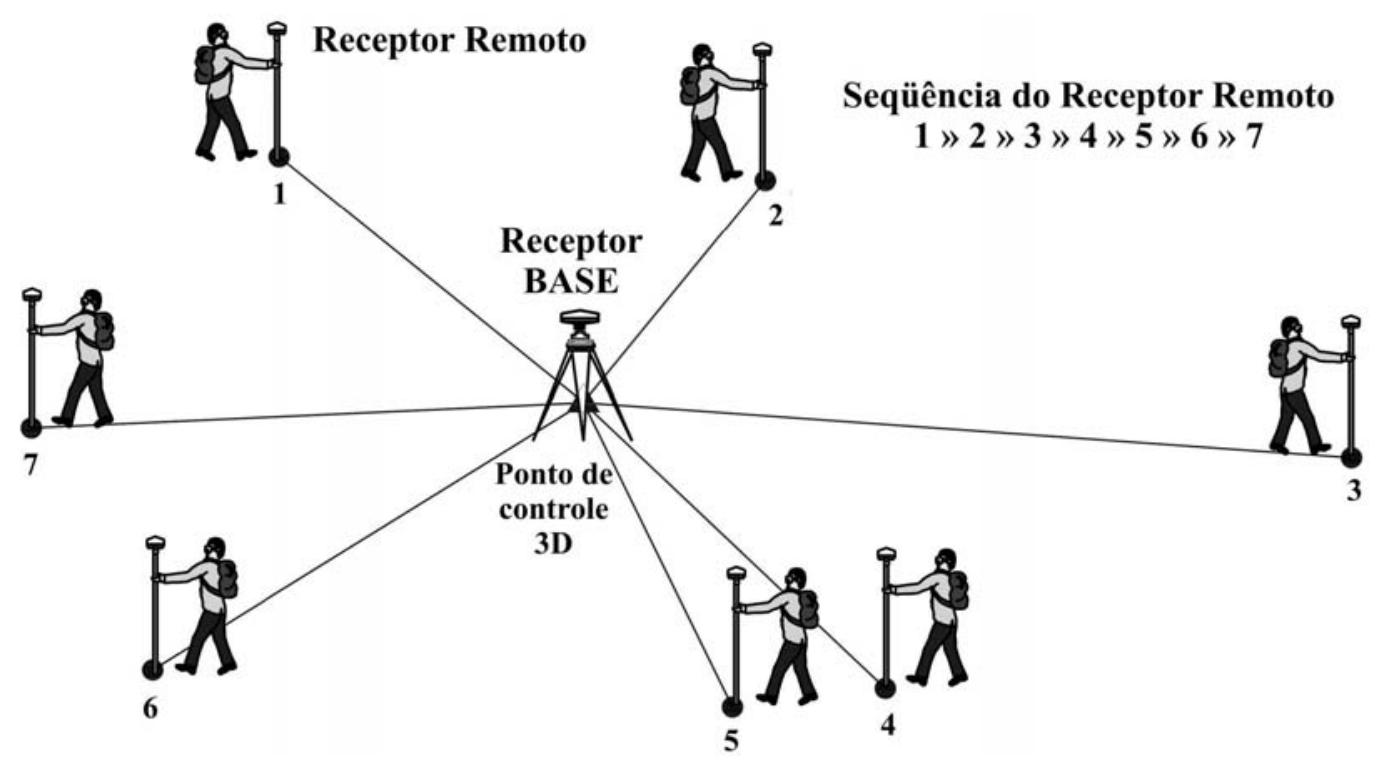

Figura 16 - Configuração de Rede GPS Radial

O receptor de base mantém-se fixo continuamente no ponto de controle tridimensional e o receptor remoto move-se para cada ponto a ser posicionado. Neste caso são feitas conexões diretas entre cada ponto e o ponto de controle (dois pontos estão diretamente conectados se forem coletadas observações de GPS simultaneamente em cada ponto e forem processados juntos). Os pontos adjacentes, por serem desconexos, têm precisão relativa bastante pobre. 
Nos posicionamentos com GPS pelo método estático convencional devem ser usadas pelo menos duas estações de controle conhecidas tridimensionalmente, ou uma combinação equivalente de estações de controle horizontais e verticais.

Uma configuração ideal de rede, levantada com GPS no modo estático convencional, deve apresentar figuras geométricas fechadas. Cada país tem suas diretrizes oficiais para projeto de rede geodésica que devem ser previamente consultadas. Normalmente as diretrizes incluem o seguinte:

1) cada estação deve ser conectada diretamente a pelo menos duas outras na rede oficial;

2) as estações adjacentes devem ser conectadas diretamente;

3) cada sessão de observação deve ter pelo menos uma linha base em comum com outra sessão.

Um exemplo de um projeto de rede que segue estas diretrizes é mostrado na Figura 17.

\begin{tabular}{|c|cccc|}
\hline \multirow{2}{*}{ Sessão } & \multicolumn{5}{|c|}{ Receptores } \\
& A & B & C & D \\
\hline 1 & C1 & 1 & 2 & 7 \\
2 & C2 & 3 & 2 & 7 \\
3 & C2 & 5 & 6 & 7 \\
4 & C2 & 5 & 3 & 4 \\
5 & C3 & 5 & 3 & 4 \\
\hline 6 & C1 & C2 & C3 & 6 \\
7 & C1 & C2 & C3 & 1 \\
\hline
\end{tabular}

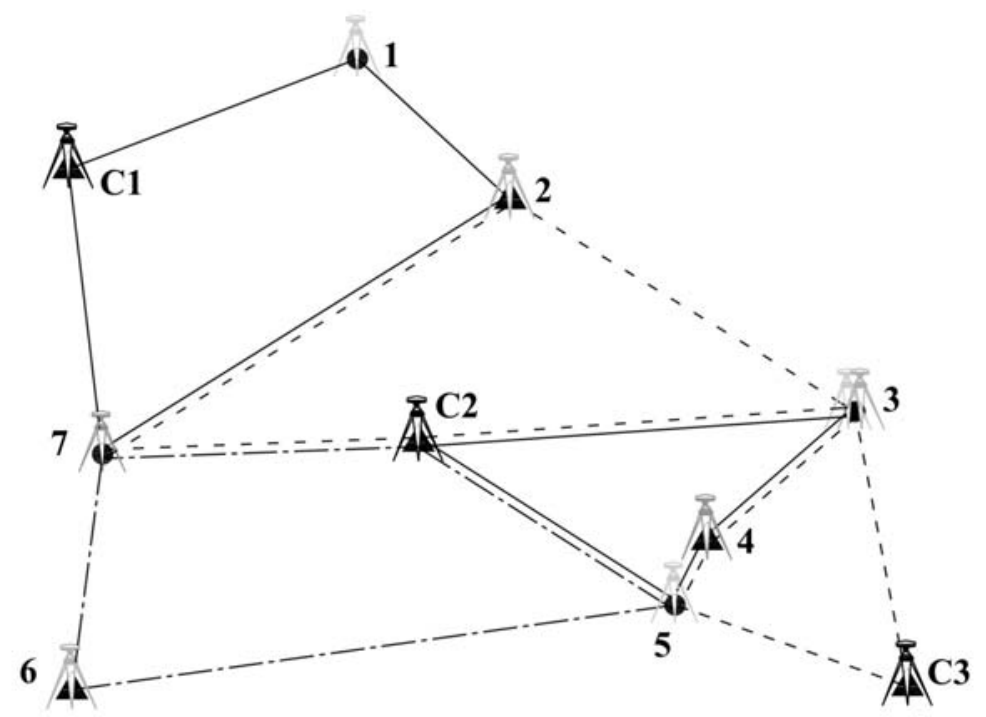

Figura 17 - Configuração de Rede GPS Convencional

Há muitos caminhos alternativos para projetar a geometria da rede mostrada na Figura 17 (este assunto não será tratado aqui, para maiores detalhes ver bibliografia). De um modo geral, os conceitos usados em um projeto de rede envolvem: situações de logística (analisadas em mapas e no reconhecimento de campo, que influenciarão no projeto padrão das sessões), o número de receptores disponibilizados para uso, o pessoal disponível e outras questões particulares ao projeto. 
Do ponto de vista operacional, a configuração de rede radial é mais atraente que a convencional, desde que o receptor remoto possa ser rápido e facilmente movido entre os pontos adjacentes, enquanto o receptor base é mantido no ponto de controle. Do ponto de vista de precisão, o enfoque radial é menos desejável devido às potenciais reduções nas precisões relativas entre as estações adjacentes desconexas. Em outras palavras, o enfoque radial não tem controle.

\section{f) Preparação do posicionamento}

Até este ponto, a maior parte das etapas do planejamento e preparação já foram relatadas (seleção do método de posicionamento, tipo de receptor, validação, reconhecimento e o projeto do posicionamento). Outros aspectos da preparação que também devem ser mencionados são:

- determinação do melhor horário para coleta dos dados de GPS, obtido da análise do almanaque (disponibilidade de satélite e geometria);

- definição do número ótimo de receptores de GPS e do pessoal para o projeto considerando os arranjos necessários;

- planejamento do projeto executivo do posicionamento, levando em consideração os pontos de controle necessários, a configuração de rede, o tempo de deslocamento entre os locais, as considerações dos satélites e as situações de logística;

- configuração e definição de um sistema de identificação único para todos os locais de posicionamento (tanto no chão como nos arquivos de dados relacionados), nas informações de posição e nos atributos associados a eles;

- preparação e configuração do projeto de medição nos receptores de GPS;

- treinamento do pessoal de operação do receptor GPS, observando os procedimentos e o processamento de dados;

- organização e providências de transporte para os locais (por exemplo, carro, helicóptero, barco, ou a pé);

- organização e providências de alojamentos ou estadias para o pessoal de campo, se for preciso;

- organização e separação de todos os equipamentos e documentos necessários, bem como os materiais de apoio às atividades de campo GPS;

- registro em planilha apropriada de todos os procedimentos anteriores conferidos e efetuados (checklist). 
O treinamento das operações do receptor deve ser minucioso e detalhado, pois muitos receptores trazem outras opções além das aplicações específicas necessárias. Normalmente os manuais apresentam instruções gerais de uso de todos os componentes de trabalho do receptor. Além desses manuais, recomenda-se a elaboração de um roteiro de instruções compacto que explique exatamente como o receptor deve ser usado no campo. Dessa forma, cada observador deverá ter, além dos manuais do receptor, um roteiro de instruções específicas para cobrir eventuais questões e dúvidas.

Quanto mais informações apresentar o mapa de projeto, maior será a fonte de referência para a preparação de campo. Um mapa básico deve mostrar os pontos de controle e as estações a serem posicionadas (adequadamente nomeadas), as recomendações de logística (elaboradas a partir do reconhecimento), o projeto de rede marcado com cores ou linhas diferentes para cada sessão (semelhante à Figura 17), e espaço para anotações e marcação das sessões de fato observadas no campo.

A fase de planejamento e preparação termina com a completa prontidão dos elementos necessários para uma bem sucedida operação de campo.

\subsection{2 - Fase de Operações de Campo}

Considerando que a fase anterior de planejamento e preparação foi feita seguindo critérios técnicos básicos para execução do projeto, as operações de campo devem ser relativamente suaves. Nas operações de campo as responsabilidades são tipicamente divididas entre o líder de campo, os observadores e o processador. Dependendo da magnitude e da metodologia do projeto, estes três grupos de responsabilidade podem ser nomeados a uma só pessoa ou compartilhados entre vários.

\section{Responsabilidades do Líder de Campo}

A responsabilidade do líder de campo é assegurar que todos os membros da equipe tenham treinamento, equipamentos e informações necessárias para executar as observações de acordo com o plano. Entre os seus deveres diários de campo incluem:

(1) programação de quais estações e quando devem ser observadas;

(2) manter-se informado sobre os problemas de satélites ou tempestades geomagnéticas;

(3) avaliar os dados e os resultados obtidos e modificar os planos quando necessário; e,

(4) controlar qualquer dificuldade de logística. 
A programação de quem deve observar em que estação e quando é muito importante para posicionamento com GPS, pois, as observações devem ser coletadas simultaneamente em locais diferentes e com ótima geometria de satélite (fundamental para o sucesso do posicionamento relativo). A programação diária deve seguir o planejamento sistemático do projeto de posicionamento (por exemplo, Figuras 16 ou 17) e mostrar para cada observador onde ele deve estar, a que horas e por quanto tempo deve rastrear. As descrições obtidas do reconhecimento devem fornecer aos observadores condições de localizar facilmente suas estações. Quando forem planejadas várias sessões de observações em um dia, o tempo de deslocamento entre as estações das sessões deve ser suficientemente seguro. A comunicação no campo deve ser contínua entre todos os observadores e o líder de campo (por meio de telefones celulares ou rádios de longo alcance), pois uma sessão planejada pode ser modificada de acordo com o progresso informado.

Informações sobre o estado dos satélites e as irregularidades da ionosfera devem ser consultadas periodicamente, pois problemas com satélites e tempestades geomagnéticas podem afetar o posicionamento com GPS. Tais informações poderão ser usadas para modificar com antecedência os horários de observação, quando necessário. Assim sendo, o líder de campo deve estar adequadamente atento e informado sobre qualquer atividade mais vigorosa para tomar as medidas cabíveis com relação à execução do posicionamento.

As observações de GPS devem ser descarregadas e processadas imediatamente após a sessão de observação para assegurar que os dados coletados tiveram êxito. Se os dados coletados não satisfizerem os padrões de aceitabilidade, o líder poderá decidir por uma re-observação.

O líder de campo também deve tomar providências para qualquer eventualidade de logística que se apresente ao longo do projeto de campo. Tais eventualidades podem variar desde as dificuldades de acesso para uma estação até uma avaria de um receptor. Como regra, um líder de campo bem preparado e sua equipe sempre analisam cuidadosamente o projeto antes de começar, pois, assim, poderão mais facilmente se adaptar aos acontecimentos inesperados do campo. 


\section{Responsabilidades dos observadores}

Depois que o horário de observação foi especificado pelo líder de campo os observadores devem saber onde, quando e por quanto tempo devem coletar as observações de GPS. As responsabilidades de campo do observador podem ser divididas em quatro fases:

(1) preparação para observações;

(2) montagem de campo;

(3) monitoramento do estado do receptor; e,

(4) encerramento das observações.

As preparações necessárias começam um dia antes das observações e podem ser consideradas precoces, mas se não forem cuidadosamente verificadas, podem conduzir ao fracasso. Os observadores devem separar e conferir todo o equipamento exigido, as folhas de registros e as descrições do local, carregar completamente as baterias do receptor, planejar adequadamente suas rotas e calcular "generosamente" o tempo de deslocamento aos seus locais.

No campo, o observador tem uma série de passos a seguir na preparação para as observações de GPS. O primeiro é verificar se o local é realmente o correto. Um esboço impresso com o número de inscrição timbrado no monumento (quando for o caso) ou uma fotografia tirada no reconhecimento pode servir como validação de que foi ocupado o local correto. O próximo passo envolve a colocação da antena de GPS sobre o ponto marcado e a medição da altura da antena (do centro de fase da antena até o ponto marcado). As exigências de precisão para centragem de uma antena sobre um ponto de posicionamento variam com o método de posicionamento GPS usado. Para posicionamentos de alta precisão, a antena de GPS deve ser centrada em cima do ponto marcado com a ajuda de uma base nivelante em um tripé (Figura 18).

A maioria das antenas projetadas para coletar observações da fase da portadora tem algum indicador de "norte" em suas coberturas. Este indicador deve ser orientado ao norte para todas as antenas que estejam coletando dados simultaneamente. Esta orientação física comum a todas as antenas ajuda a minimizar erros sistemáticos os quais podem resultar em variações no centro de fase das antenas. 
A medida da altura da antena é uma responsabilidade do observador, e requer bastante atenção por causa da possibilidade de erro. A altura da antena é a distância vertical entre o ponto marcado e o centro de fase da antena. A medida da altura da antena é tomada a partir de um ponto de referência na antena (base da antena) até o ponto ocupado (materializado). Normalmente a altura entre a base e o centro de fase de antena conhecida como "off-set" da antena é informado pelo fabricante e automaticamente adicionada ao valor medido (ver Figura 18).

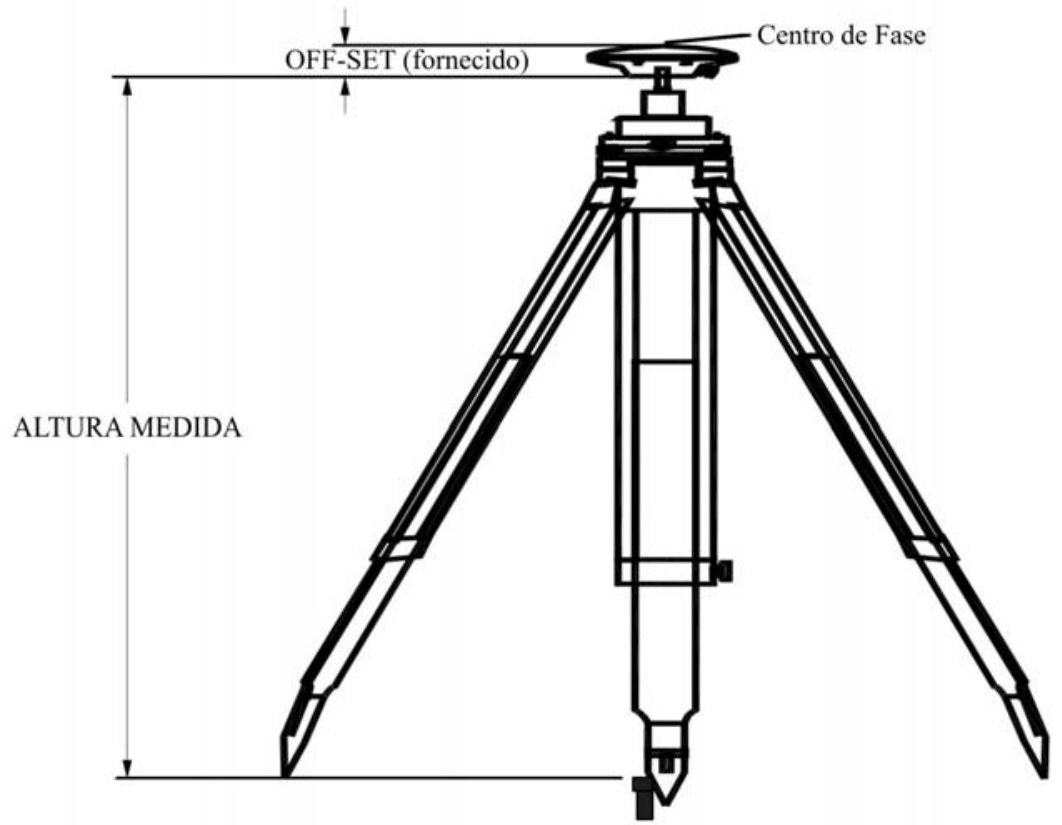

Figura 18 - Medição da altura da antena

Caso não seja possível fazer as medidas verticais diretas, podem ser feitas medidas da altura inclinada e então calcular a distância vertical, usando o teorema de Pitágoras:

$$
\text { altura medida }=\sqrt{(\text { altura inclinada })^{2}-(\text { raio da antena })^{2}}
$$

Em todos os casos devem ser feitas medidas redundantes da altura da antena. No caso da medida de alturas inclinadas, essas devem ser tomadas em cada lateral da antena, no início e no fim dos períodos de observação.

A forma como a altura da antena foi medida e o método usado deve ser registrado claramente na folha de observação de campo e no terminal de controle para prevenir qualquer má interpretação pelo processador. Uma vez que a antena esteja corretamente centrada e a sua altura medida e registrada, o receptor deve ser inicializado para coletar dados seguindo as instruções preparadas. 
A próxima tarefa do observador é garantir que o receptor esteja trabalhando sem dificuldades. Isto inclui o preenchimento de um conjunto de planilhas de registro de campo exclusivo para cada local, contendo um registro único das condições enfrentadas no campo ou das dificuldades submetidas. As informações que devem ser documentadas incluem:

- $\quad$ nome e identificação do local para o arquivo de dados do receptor;

- o nome do observador;

- $\quad$ o tipo de antena e receptor e seus números de série;

- a altura da antena e uma explicação de como foi medida;

- a hora de início da coleta de dados e a hora de finalização;

- lista de verificação (checklist) com informações coletadas na tela de exibição do receptor, durante todo o período de medição, por exemplo: quantos satélites estão sendo rastreados, o valor do DOP, se os dados estão sendo armazenados, a capacidade de armazenamento disponível, a carga da bateria e outros elementos que forem necessários, conforme definidos no projeto. Esta verificação pode ser repetida periodicamente durante o rastreio para certificar-se de que o sistema está funcionando perfeitamente;

- os problemas manifestados e as ações tomadas.

Um exemplo de um registro do posicionamento de campo com GPS pelo método estático convencional é mostrado no Apêndice C. O formato da planilha de registro pode variar, dependendo das exigências do cliente e dos padrões da empresa, podendo ser folhas de papel ou arquivo digital via computador portátil (palm top, lap top e semelhados).

Ao terminar as observações, o observador deve assegurar que todos os dados foram registrados, re-conferir a altura e a centragem da antena, e só então desligar, desconectar e acondicionar o equipamento conforme as instruções. Para finalizar, deve encerrar as folhas de registro de campo. Após retornar de um dia de observações, cada observador deverá entregar as planilhas dos registros de campo e os dados coletados ao técnico processador. 


\section{Responsabilidades do técnico processador}

É de extrema importância processar os dados de GPS imediatamente após a coleta dos dados para identificar possíveis problemas enquanto estão fáceis de resolver. Este processamento de dados pode acontecer em um computador (portátil) em um acampamento ou hotel (se as operações de campo estiverem sendo conduzidas em viagem), ou em um computador específico no escritório para o caso de posicionamentos realizados em locais próximos da empresa.

Os deveres (tarefas) do técnico processador começam assim que são entregues os dados e as folhas de registros de campo do dia de observações. Os dados submetidos devem ser verificados para assegurar que estão claros, completos e precisos. Os dados devem ser descarregados do receptor ou de suas mídias de armazenamento e arquivados no computador e em cópias de segurança (backup dos dados brutos). A empresa deverá estabelecer e manter um sistema eficiente de administração dos dados recebidos e das cópias de segurança geradas.

O técnico processador deve fazer um processamento suficiente (mínimo) para julgar se os dados coletados têm qualidade adequada para aplicações, ou seja, analisar o resultado do processo para avaliar a qualidade dos dados, comparar as medidas redundantes, e assim por diante, e passar os resultados para o líder de campo tomar as decisões sobre a necessidade ou não de re-observações ou revisões de planos.

Todos os procedimentos adotados nessa etapa de processamento devem ser registrados em uma planilha incluindo as dificuldades apresentadas e as ações tomadas. Isto servirá como referência do que foi feito com os dados, quando e por quê. O ideal seria que todo o processamento dos dados fosse feito no campo, porém, isso nem sempre será possível devido a limitações de tempo e à necessidade de um processamento mais rigoroso.

De um modo geral, as principais ações e responsabilidades relacionadas aos membros da equipe de posicionamento com GPS podem ser resumidas conforme apresentado a seguir na Tabela 5. 
Tabela 5 - Responsabilidades de Campo

\begin{tabular}{|c|c|}
\hline Função & Responsabilidades \\
\hline Líder & $\begin{array}{l}\text { - } \text { Programar as observações como planejado } \\
\text { - } \text { - } \text { Acrificar problemas e influências nos satélites } \\
\text { - Controlar qualquer dificuldade de logística } \\
\text { - Configurar o receptor de acordo com o tipo de medição a ser realizada. }\end{array}$ \\
\hline Observadores & $\begin{array}{l}\text { - Verificar se tem todo o equipamento exigido } \\
\text { - } \text { Assegurar que as baterias do receptor estão completamente carregadas } \\
\text { - Deixar tempo amplo (suficiente) para deslocamento ao local } \\
\text { - Verificar se a estação correta está sendo ocupada } \\
\text { - Nivelar, centrar e orientar a antena de GPS sobre o ponto marcado } \\
\text { - Medir a altura da antena } \\
\text { - Inicializar o receptor } \\
\text { - Monitorar a operação e a gravação dos dados do receptor } \\
\text { - } \\
\text { - Sreencher as folhas de registro da estação }\end{array}$ \\
\hline Processador & $\begin{array}{ll}\text { - } & \text { Descarregar os dados } \\
\text { - } & \text { Verificar os dados submetidos } \\
\text { - } & \text { Orgar cópia de segurança dos dados brutos (backup) } \\
\text { - } & \text { Processar os dados de GPS } \\
\text { - } & \text { Ajustar todas as sessões juntas, se for determinado } \\
\text { - } & \text { Conferir os resultados e informar ao líder }\end{array}$ \\
\hline
\end{tabular}

\subsection{3 - Fase de Processamento dos dados e Relatório final}

Neste ponto as fases mais críticas do projeto com GPS já foram realizadas (Figura 12). O processamento e o relatório final dos dados não são tão críticos como o planejamento, a preparação e as operações de campo, mas ainda é preciso atenção, prudência, competência e prática para finalizar com sucesso o projeto.

A complexidade do processamento dos dados corresponde diretamente à complexidade do método de posicionamento GPS usado. Em geral, os receptores (comprados ou alugados) são acompanhados por software para o processamento dos dados de GPS. A maioria desses pacotes de softwares é automatizada, porém, vale ressaltar a importância dos relatórios do posicionamento e o conhecimento geral do projeto pelos responsáveis pela etapa de processamento dos dados coletados com GPS. 
Nas soluções de posicionamentos relativos pelos métodos diferenciais que usam as observações do código, os dados da estação de monitoramento e de todos os locais remotos devem ser descarregados em um computador. No programa de processamento são confrontados os tempos de observações do código feito em cada local remoto com o feito na estação de monitoramento. Usando os dados das efemérides de cada satélite, as coordenadas conhecidas do receptor de base, e as medidas do código, o programa calculará as coordenadas para cada local remoto.

O processamento de um posicionamento relativo com GPS pelo método estático convencional é mais complexo e pode requerer uma combinação de várias sessões de observações. Todos os dados devem ser descarregados no computador. Também é imprescindível conhecer as coordenadas tridimensionais dos pontos de controle para informar ao programa de processamento. Para cada sessão processada, a maioria dos softwares solicita um ponto tridimensional fixo, e se não for incluído um ponto de controle em uma sessão específica, são usadas as coordenadas de um local em comum com a sessão adjacente e adotadas neste caso como ponto de controle.

No algoritmo do processamento GPS podem ser usados modelos para corrigir alguns erros sistemáticos nas observações. Dessa forma, todas as observações, os dados das efemérides e as coordenadas conhecidas são combinadas da melhor maneira (ajustamento) para se chegar a uma solução. Dependendo do comprimento da linha de base, também são feitas tentativas para solucionar o número inteiro de ambigüidades da fase da portadora. Se isto for feito corretamente, a solução resultante terá precisão mais alta. A solução final consiste nas diferenças de coordenadas entre cada estação incluída na sessão e as informações de precisão relacionada.

Muitos dos erros orbitais, incluindo os introduzidos pela disponibilidade seletiva, podem ser reduzidos significativamente se forem usadas as efemérides precisas em vez das efemérides transmitidas. As efemérides transmitidas são baseadas em predições de onde o satélite estará no céu em um determinado momento. As determinações mais precisas da posição do satélite são obtidas pelo rastreamento desses satélites por estações ao redor do mundo, que combinam esses dados e calculam a posição precisa dos satélites no céu. O uso das efemérides precisas pós-calculadas pode melhorar as precisões para posicionamentos precisos. As efemérides precisas são disponibilizadas por várias instituições, entre elas o NGS - National Geodetic System. 
Para combinar as várias sessões de informação juntas em uma solução, deverá ser feito um ajuste de rede usando um software projetado para este propósito. O ajuste de rede combina todas as diferenças de coordenadas de todas as sessões de observações de um modo otimizado. Alguns pacotes de softwares GPS incluem também capacidades de ajuste de rede. Um ajustamento de rede, para ser eficiente, deve seguir todas as exigências do projeto de posicionamento aplicadas para o método usado e descritas anteriormente. O ajustamento inicial da rede deve ter uma amarração mínima (só um ponto de controle tridimensional deve ser fixado) para possibilitar uma análise minuciosa dos resultados do GPS sem a influência dos controles existentes. O resultado de um processamento GPS estático convencional pode ser conferido pela comparação das linhas bases redundantes e por meio de testes estatísticos no processo de ajustamento (maiores detalhes ver bibliografia).

O software de processamento deve ser avaliado e treinado antes do processamento. Normalmente o fabricante do equipamento também fornece o software de processamento que melhor se adapta ao conjunto e dá o treinamento básico de como usá-lo. Um resumo das características principais de um pacote pode ser verificado em Hofmann-Wellenhof et al. (2001).

Quando todas as operações de campo e as observações processadas estiverem completas, deve ser elaborado um relatório final do projeto contendo a documentação das estações ocupadas, os métodos usados e os resultados atingidos (item 2.1.8). Dessa forma, o cliente está consciente de receber um trabalho bem feito e a empresa, a confiança por ter executado mais um serviço com qualidade, além das melhorias incorporadas que serão continuamente aplicadas nos procedimentos para os próximos projetos de posicionamento com GPS. A Figura 19 representa o macroprocesso de um posicionamento genérico efetuado com o sistema GPS. (sugestão do autor)

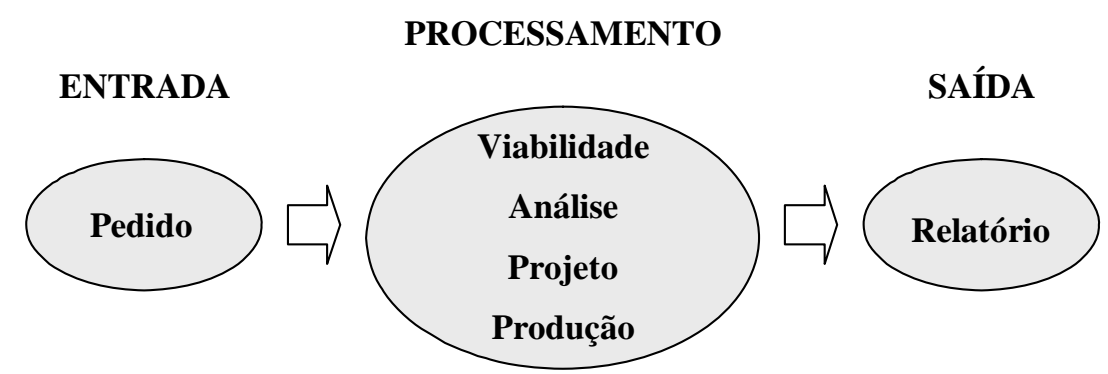

Figura 19 - Esquema do macroprocesso de posicionamento com GPS 


\section{6 - A GESTÃO ORGANIZACIONAL DA EMPRESA}

A empresa de medições e posicionamentos tem como característica principal a prestação de serviços e normalmente é contratada como fornecedora para outras empresas de diversos ramos como a indústria da construção civil, agricultura, transportes, instituições de pesquisa, mineradoras, prefeituras e governos, entre outras.

As recentes políticas de Qualidade adotadas pelos principais clientes têm exigido das empresas de medições e posicionamentos maior controle e garantia de seus serviços por meio da adoção de sistemas de gestão organizacional compatível com as políticas adotadas pelas empresas contratantes. Essas mudanças, junto com o avanço tecnológico e a vontade de inovação dos novos empreendedores, têm evoluído bastante nos últimos anos, fazendo com que as empresas do setor busquem alternativas para se tornarem mais competitivas e permanecer no mercado, que a cada dia se torna mais exigente.

Em uma pesquisa realizada recentemente para conhecer a situação das empresas que prestam serviços de posicionamento com GPS (Apêndice B), verificou-se que apenas $12 \%$ das empresas consultadas (13) possuem algum tipo de sistema de gestão organizacional documentado e implantado, número este considerado bastante reduzido. Dos 88\% restante (92), cerca de 87\% (80) têm interesse em saber mais sobre os Sistemas de Gestão da Qualidade e pretendem implantá-los em um futuro próximo e apenas uma pequena parte, 13\% (12) dos que não adotam qualquer tipo de gestão responderam que pretendem continuar do jeito que estão.

Os resultados dessa pesquisa mostram que a maioria das empresas que presta serviços de posicionamento com GPS não apresenta uma estrutura organizacional documentada, ou seja, apresenta uma estrutura informal centralizada. Verificou-se também que há interesse dessas empresas em conhecer mais sobre os sistemas de gestão e suas vantagens. Segundo relatos de algumas empresas consultadas, existem em certas regiões o que eles denominaram de “filtro, peneira, crivo etc.” no mercado, cujo elemento chave principal de passagem é o Certificado de Qualidade, adotado tanto por parte dos contratantes dos serviços como das instituições bancárias e de financiamento empresarial. 
Esse “filtro", relatado pelos entrevistados, é fruto de um movimento da qualidade surgido a partir dos anos 90 (na área de topografia e geodésia) que teve grande crescimento no estado de São Paulo, principalmente em função do apoio e do incentivo dado pelos diversos sindicatos empresariais que compõem os setores da indústria da Construção Civil, da Agroindústria, e entre eles o das empresas de medições topográficas. Outro evento marcante, na adoção da qualidade como elemento indutor do avanço tecnológico do setor, foi a instituição do Programa QUALIHAB pelo governo do estado de São Paulo, através da Companhia de Desenvolvimento Habitacional e Urbano - CDHU.

Esse programa, entre suas diversas ações, prevê a exigência de um atestado de qualidade para as empresas que prestam serviços para a CDHU. Um sistema de certificação próprio do programa, baseado nas normas da série NBR/ISO 9000 e adaptado à realidade do setor (AETESP, 2001). Com isso, as empresas que atuam no mercado de prestação de serviços e habitações populares no estado de São Paulo se viram obrigadas a desenvolver e implementar Sistemas da Qualidade, caso contrário, seriam excluídas deste mercado.

A iniciativa paulista do QUALIHAB foi estendida para todo o território nacional, por meio da implementação do Programa Brasileiro de Qualidade e Produtividade do Habitat - PBQP-H, que também inclui entre suas ações a certificação da Qualidade das empresas construtoras e seus fornecedores através de um Sistema de Certificação próprio (BRASIL, 2000). Outras ações e programas locais ou regionais relacionados à Gestão da Qualidade também estão ocorrendo ou serão em breve aplicados ao setor em todo o país.

De um modo geral, a estrutura organizacional, seja formal ou informal, deverá representar a forma como são agrupados e coordenados os recursos (humanos, físicos e financeiros) empregados nos diversos processos desenvolvidos na organização com o intuito de atingirem seus objetivos. 


\section{4 - A QUALIDADE}

Atualmente a palavra Qualidade é bastante difundida (tanto na sociedade como nas empresas), embora haja ainda pouco entendimento sobre o que é Qualidade. Isso tem provocado algumas confusões no uso dessa palavra. O motivo principal do embaraço é a existência de um subjetivismo associado à qualidade e seu uso genérico para representar coisas distintas.

Genericamente o termo Qualidade é definido como “propriedade, atributo ou condição das coisas ou das pessoas capaz de distingüi-las das outras e de lhes determinar a natureza” (FERREIRA, 1999). Embora apareça como um atributo intrínseco, a Qualidade não é identificável e observável diretamente, ou seja, a Qualidade é resultante da interpretação de uma ou mais características das coisas ou pessoas, fato que atribui à palavra uma dimensão subjetiva.

Segundo Toledo (2001), esse subjetivismo contribui para a confusão no emprego da palavra Qualidade, visto que cada pessoa, quando se refere a ela, está querendo dizer coisas diferentes a partir do seu ponto de vista. O seu uso genérico para representar coisas distintas faz da palavra uma espécie de "guarda-chuva” que abriga e se confunde com outros conceitos, tais como produtividade e eficiência.

A palavra Qualidade deve então ser sempre empregada de forma composta, isto é, explicitando sempre qual substantivo a que se refere, por exemplo, qualidade do produto, qualidade do processo, qualidade do sistema, qualidade da gestão, etc. Neste trabalho refere-se a produtos de engenharia, isto é, qualidade de produtos de engenharia. 
A definição de Qualidade apresenta grandes variações por ser um conceito relativo, extremamente abrangente pela qual, de um modo geral, se tenta dar um único sentido. Suas variações tanto em amplitude como em profundidade sempre giram em torno dos conceitos de conformidade, adequação ao uso e satisfação ao cliente. Ao se pensar de forma sistêmica pode-se entendê-la como a interação das variáveis: produto, cliente e uso.

\section{1 - EVOLUÇÃO HISTÓRICA}

Desde os primórdios da humanidade a qualidade está presente na vida do homem, a partir do momento em que ele procurou o que fosse melhor ou o que mais se adequasse às suas necessidades. Na Antigüidade, por exemplo, por volta de $1780 \mathrm{a}$. C foi escrito o código de Hammurabi (KING, 2004), o qual previa que se um construtor erguesse uma casa para alguém e seu trabalho não fosse sólido e a casa desabasse e matasse o morador, o construtor seria imolado. A qualidade também se fez presente nas construções das pirâmides, na arquitetura de diversos povos da antiguidade, bem como no desenvolvimento de fórmulas matemáticas. Na Grécia, (CARVALHO, 2002) a história antiga pode ser caracterizada por uma arquitetura de extrema precisão e alta qualidade e padrões para artes em geral. Em Roma, também se destacam os modelos arquitetônicos, a alvenaria e a engenharia de estruturas, fatos que mostram na história antiga a qualidade mais relacionada ao produto final.

\section{Era da Inspeção}

A Idade Média foi marcada pela presença de artesãos e artífices que eram responsáveis pela fabricação de seus produtos com qualidade. Nesse período são definidos os padrões rudimentares da Qualidade para bens e serviços e os níveis básicos de desempenho da mão de obra, com a determinação das condições gerais para o trabalho humano. (PALADINI, 1995). No início do século XX, a Administração Científica de Taylor deu ênfase à padronização de todos os produtos, com a industrialização e a produção em massa foram desenvolvidos sistemas baseados em inspeções, onde um ou mais atributos eram examinados, medidos ou testados. Surge então a figura do inspetor ou supervisor da Qualidade, que no final do processo fazia a inspeção e o controle separando os produtos “bons” dos “maus”. 


\section{Era do Controle Estatístico da Qualidade (controle do processo)}

Para atender às reais necessidades dos clientes, foram desenvolvidas técnicas estatísticas para controlar a qualidade. Walter A. Shewhart reconheceu a variabilidade como inerente aos processos industriais, utilizando técnicas estatísticas para o controle de processos. Nesta fase houve o estabelecimento de padrões mínimos para a aceitação dos produtos, ferramenta que ainda hoje é utilizada na Qualidade.

Durante a Segunda Grande Guerra desenvolveram-se outras técnicas com o objetivo de combater a ineficácia e a impraticabilidade apresentadas pela inspeção 100\%. Nesse período, o crescimento das indústrias e a utilização de mão de obra pouco preparada pela urgência de produção interferiram nos níveis da qualidade de produtos e serviços. Estes aspectos geraram a necessidade da estruturação de programas formais de qualificação de pessoal, além dos procedimentos de controle e inspeção, passando então a ser considerada a importância do papel das pessoas na aplicação de procedimentos e manutenção de padrões.

\section{Era da Garantia da Qualidade}

Após a Segunda Grande Guerra, dissemina-se no Japão o conceito de círculos da Qualidade, dentro de um modelo que viria mais tarde a ser conhecido como a abordagem participativa da qualidade. Percebe-se, mais uma vez, a importância das pessoas no processo de melhoria da Gestão da Qualidade nas organizações. Esse período do pós-guerra foi marcado por desenvolvimentos como: quantificação dos custos da Qualidade proposto por Juran em 1951, pelo controle da Qualidade Total por Feigenbaum em 1956, pelas técnicas de confiabilidade desenvolvidas pelas indústrias aeroespacial, eletrônica e militar, e pelo programa “Zero Defeito” de Crosby em 1961, conceitos e ferramentas muito utilizados ainda nos dias atuais.

\section{Era da Gestão da Qualidade Total (Gestão Estratégica)}

Estima-se que essa era teve inicio no final da década de 70, a partir da invasão no mercado americano dos produtos japoneses de alta qualidade. É a soma e conseqüência das três antecessoras e está em curso até hoje, quando sofreu uma alteração para Gestão Estratégica da Qualidade. A Gestão da Qualidade enfoca a valorização dos clientes como fator fundamental para se preservar e ampliar a participação no mercado, com a visão de que seja aplicado em tudo o que se faz na empresa e em todos os níveis. 
A alta administração deve reconhecer o impacto da Qualidade no sucesso competitivo da empresa, passando a merecer a sua atenção rotineira e integrando-se na gestão estratégica do negócio, ou seja, o convencimento da alta administração é fundamental para a inserção da Gestão da Qualidade na vida de qualquer organização.

A Gestão da Qualidade deve prever ações de planejamento, controle e aprimoramento contínuo de cada processo, tendo como objetivo central a satisfação dos clientes. Em outras palavras, a Qualidade significa atender a todos os envolvidos, sejam clientes, fornecedores, funcionários, acionista ou mesmo parte da sociedade afetada pelo desempenho da organização.

Em uma era de economia global, a Qualidade passou a ser associada à lucratividade e transformou-se em uma arma de concorrência tanto do mercado quanto do custo. Não é mais possível garantir a sobrevivência da empresa apenas exigindo que as pessoas façam o melhor que puderem ou cobrando apenas resultados. Em outras palavras, se o objetivo é atingir a Qualidade Total deve-se medir a qualidade do produto ou serviço, o número de reclamações dos clientes, os atrasos, o custo do produto/serviço, para saber se a qualidade foi alcançada ou não. Para que isso ocorra, a organização dever possuir um Sistema da Qualidade bem estruturado (CAMPOS, 1999). A Figura 20 apresenta a evolução das quatro Eras da Qualidade:

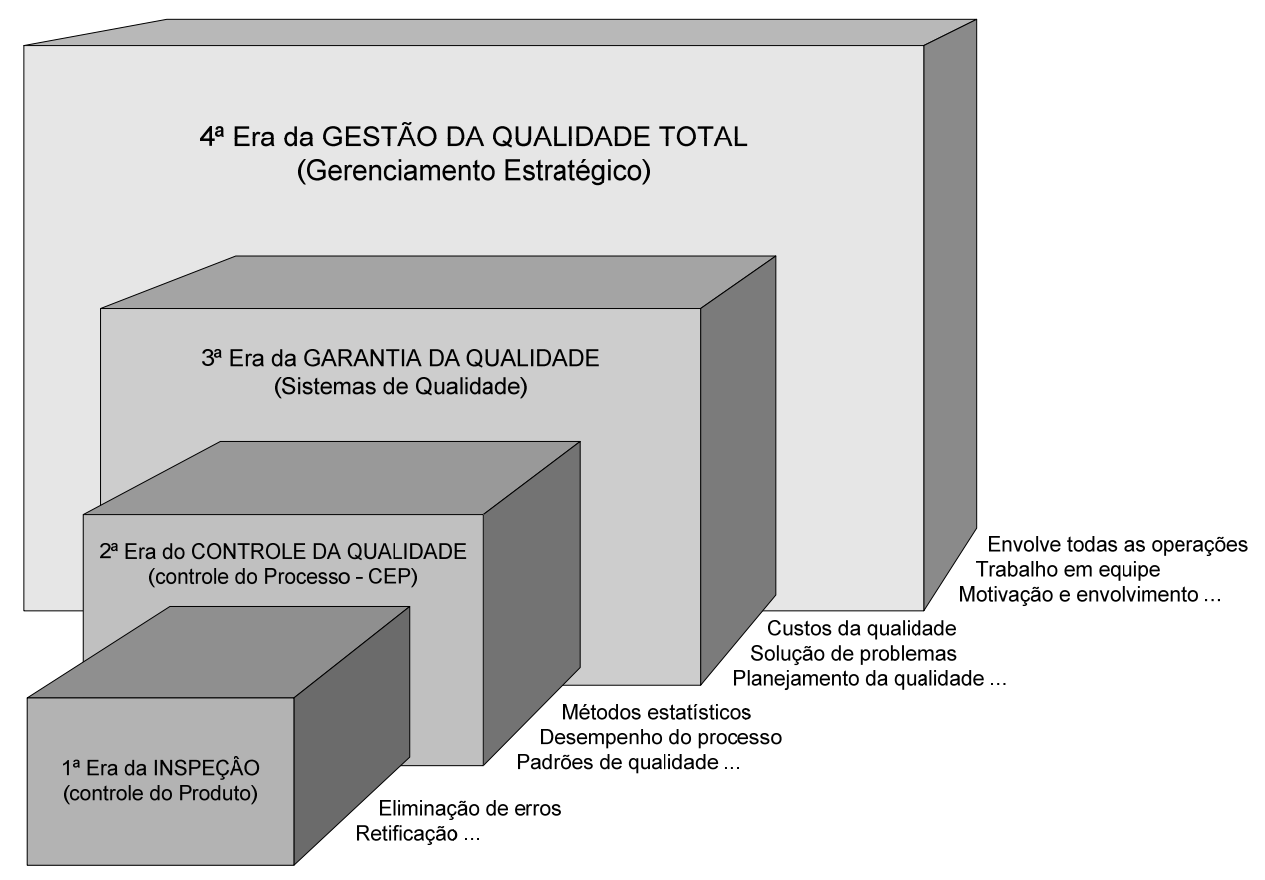

Figura 20 - Evolução das Eras da Qualidade 
Um resumo das principais características de cada Era é apresentado a seguir na Tabela 6

Tabela 6 - Resumo das Principais Eras da Qualidade

\begin{tabular}{|c|c|c|c|c|}
\hline \multirow[b]{2}{*}{ Características } & \multicolumn{4}{|c|}{ Etapa do Movimento da Qualidade } \\
\hline & Inspeção & $\begin{array}{c}\text { Controle } \\
\text { Estatístico da } \\
\text { Qualidade } \\
\end{array}$ & $\begin{array}{c}\text { Garantia da } \\
\text { Qualidade }\end{array}$ & $\begin{array}{c}\text { Gerenciamento } \\
\text { Estratégico da } \\
\text { Qualidade }\end{array}$ \\
\hline $\begin{array}{l}\text { Preocupação } \\
\text { básica }\end{array}$ & verificação & controle & coordenação & impacto estratégico \\
\hline $\begin{array}{l}\text { Visão da } \\
\text { Qualidade }\end{array}$ & $\begin{array}{l}\text { um problema a ser } \\
\text { resolvido }\end{array}$ & $\begin{array}{l}\text { um problema a ser } \\
\text { resolvido }\end{array}$ & $\begin{array}{l}\text { um problema a ser } \\
\text { resolvido, mas que } \\
\text { seja enfrentado } \\
\text { proativamente }\end{array}$ & $\begin{array}{l}\text { uma oportunidade } \\
\text { de concorrência }\end{array}$ \\
\hline Ênfase & $\begin{array}{l}\text { uniformidade do } \\
\text { produto }\end{array}$ & $\begin{array}{l}\text { uniformidade do } \\
\text { produto com menos } \\
\text { inspeção }\end{array}$ & $\begin{array}{l}\text { toda a cadeia de } \\
\text { produção, desde o } \\
\text { projeto até o } \\
\text { mercado, e a } \\
\text { contribuição de } \\
\text { todos os grupos } \\
\text { funcionais, } \\
\text { especialmente os } \\
\text { projetistas, para } \\
\text { impedir falhas de } \\
\text { qualidade }\end{array}$ & $\begin{array}{l}\text { as necessidades de } \\
\text { mercado e do } \\
\text { consumidor }\end{array}$ \\
\hline Métodos & $\begin{array}{l}\text { instrumentos de } \\
\text { medição }\end{array}$ & $\begin{array}{l}\text { instrumentos e } \\
\text { técnicas estatísticas }\end{array}$ & $\begin{array}{l}\text { programas e } \\
\text { sistemas }\end{array}$ & $\begin{array}{l}\text { planejamento } \\
\text { estratégico, } \\
\text { estabelecimento de } \\
\text { objetivos e a } \\
\text { mobilização da } \\
\text { organização }\end{array}$ \\
\hline $\begin{array}{l}\text { Papel dos } \\
\text { profissionais da } \\
\text { qualidade }\end{array}$ & $\begin{array}{l}\text { inspeção, } \\
\text { classificação, } \\
\text { contagem e } \\
\text { avaliação }\end{array}$ & $\begin{array}{l}\text { solução de } \\
\text { problemas e a } \\
\text { aplicação de } \\
\text { métodos estatísticos }\end{array}$ & $\begin{array}{l}\text { mensuração da } \\
\text { qualidade, } \\
\text { planejamento da } \\
\text { qualidade e projeto } \\
\text { de programas }\end{array}$ & $\begin{array}{l}\text { estabelecimento de } \\
\text { objetivos, educação } \\
\text { e treinamento, } \\
\text { trabalho consultivo } \\
\text { com outros } \\
\text { departamentos e } \\
\text { delineamento de } \\
\text { programas }\end{array}$ \\
\hline $\begin{array}{l}\text { Quem é o } \\
\text { responsável pela } \\
\text { qualidade }\end{array}$ & $\begin{array}{l}\text { o departamento de } \\
\text { inspeção }\end{array}$ & $\begin{array}{l}\text { os departamentos } \\
\text { de produção e } \\
\text { engenharia }\end{array}$ & $\begin{array}{l}\text { todos os } \\
\text { departamentos, } \\
\text { embora a alta } \\
\text { gerência só se } \\
\text { envolva } \\
\text { perifericamente } \\
\text { com o projeto, o } \\
\text { planejamento e a } \\
\text { execução das } \\
\text { políticas da } \\
\text { qualidade }\end{array}$ & $\begin{array}{l}\text { todos na empresa, } \\
\text { com a alta gerência } \\
\text { exercendo forte } \\
\text { liderança }\end{array}$ \\
\hline $\begin{array}{l}\text { Orientação e } \\
\text { Abordagens }\end{array}$ & $\begin{array}{l}\text { “inspeciona a } \\
\text { qualidade” }\end{array}$ & $\begin{array}{l}\text { "controla a } \\
\text { qualidade" }\end{array}$ & $\begin{array}{l}\text { “constrói a } \\
\text { qualidade” }\end{array}$ & $\begin{array}{l}\text { “gerencia a } \\
\text { qualidade” }\end{array}$ \\
\hline
\end{tabular}

Fonte: (GARVIN, 1992) 


\section{2 - PRINCIPAIS AUTORES “GURUS” DA QUALIDADE}

Ao longo da história, vários autores apresentaram abordagens diferentes sobre o tema Qualidade, fazendo com que seja necessário conhecer as terminologias empregadas, já que o tema está em constante evolução. Entre os principais autores, alguns são conhecidos mundialmente como "Gurus ou notáveis da Qualidade”, pois deixaram valiosas contribuições para a evolução do conceito da qualidade. São eles: William E. Deming, Joseph M. Juran, Armand V. Feigenbaum, Philip B. Crosby, Kaoru Ishikawa, Genichi Taguchi e David A. Garvin. Cada um desses autores, apesar de tratarem do mesmo assunto (Qualidade), apresenta abordagens com enfoque e amplitude diferentes, sintetizadas a seguir:

\section{William E. Deming:}

Para Deming (1990), a Qualidade é qualquer coisa que o cliente necessita ou deseja, e como essas necessidades e desejos estão sempre mudando a solução para defini-la em termos de cliente é redefinir os requisitos constantemente. Assim sendo, a Qualidade deve estar orientada às necessidades dos clientes, tanto atuais como futuras, ou seja, "a qualidade não significa luxo”.

O enfoque de Deming para a Qualidade é voltado para o uso da estatística em processos, focalizando os problemas da variabilidade e suas causas. Técnicas estatísticas, como gráficos de controle de processos, são propostas por permitirem a distinção entre "causas especiais e comuns", as primeiras atribuídas a indivíduos ou máquinas, e as outras de responsabilidade geral como falhas de matérias primas.

Deming enfatiza uma abordagem sistêmica para a solução de problemas da Qualidade, conhecida como Ciclo de Deming ou Ciclo PDCA - Plan, Do, Check, Action. Método base para a análise de processos em todos os níveis da organização.

\section{Joseph M. Juran:}

De acordo com Juran e Gryna (1991), embora a palavra Qualidade possua várias interpretações, é conveniente destacar dois significados importantes:

- Qualidade consiste nas características de produtos que atendem as necessidades dos clientes e, portanto, proporcionando satisfação e

- Qualidade é a ausência de deficiências. 
E para padronizar uma definição mais curta que englobasse estas duas características, Juran define Qualidade como “adequação ao uso”, ou seja, deve ser conceituada a partir do usuário, e ser vista de maneira global e holística em todos os aspectos do gerenciamento em uma organização.

\section{Armand V. Feigenbaum:}

Para Feigenbaum (1994), a Qualidade é um conjunto de características incorporadas ao produto através do projeto e manufatura que determina o grau de satisfação do cliente. Ele afirma que qualidade é muito mais que gerenciamento de defeito no chão de fábrica, é uma filosofia e um compromisso com a excelência, um modo de vida da corporação, uma metodologia gerencial.

A contribuição de Feigenbaum refere-se ao conceito de TQC (Total Quality Control), ou traduzido para o português como CQT (Controle da Qualidade Total) nos anos 60 e 70, como um sistema eficiente para a integração do desenvolvimento da qualidade, da manutenção da qualidade e dos esforços de melhoramento da qualidade em todos os níveis econômicos e por toda a empresa.

\section{Philip B. Crosby:}

Crosby (1999) define Qualidade como “conformidade com os requisitos” medida pelo custo da não-qualidade. A Qualidade é considerada um estado binário:

- ou há conformidade (Qualidade),

- ou há não-conformidade (não-qualidade).

Usando esta abordagem, Crosby desenvolveu, em 1961, o conceito de "zero defeito", enfatizando que todas as pessoas da companhia são capazes de fazer o seu trabalho de maneira correta na primeira e em todas as vezes.

Segundo Crosby, para que todos os requisitos dos clientes sejam cumpridos e com isso obtido a qualidade dos produtos e serviços que eles desejam, cabe à gerência realizar três tarefas básicas:

- estabelecer os requisitos que os empregados devem cumprir;

- fornecer recursos materiais de que necessitam para cumprir tais requisitos e,

- permanecer incentivando e ajudando os empregados a cumprir tais requisitos 


\section{Kaoru Ishikawa:}

Segundo Ishikawa (1997), a "Qualidade começa e termina com a educação". O primeiro passo para a qualidade é o conhecimento dos requisitos dos clientes, portanto, o marketing é a entrada e a saída da qualidade. Para Ishikawa, a Gestão da Qualidade consiste em desenvolver, criar e fabricar mercadorias mais econômicas, úteis e satisfatórias para o comprador.

Em sua obra é forte a ênfase no papel social da empresa, numa ação que contempla fatores humanos dentro e fora da organização, ou seja, deve-se compreender a qualidade como inerente ao trabalho, fazendo parte e sendo resultado do trabalho, com a construção da qualidade de vida de cada indivíduo e da sociedade.

\section{Genichi Taguchi:}

De acordo com Taguchi (1990), a “Qualidade consiste em minimizar as perdas causadas pelo produto não apenas ao cliente, mas à sociedade em longo prazo”. A razão das perdas para o cliente e para a sociedade é a dispersão (variabilidade). Taguchi desenvolveu técnicas específicas visando à redução da variabilidade dos produtos oriundos de processos que envolvem energia física.

Para Taguchi, "o preço representa para o consumidor uma perda na hora da compra, e a baixa qualidade representa uma perda adicional durante o uso do produto”. Ele adotou o termo engenharia da qualidade em que um dos objetivos deve ser a redução da perda total para o cliente. O autor utiliza-se uma curva parabólica para descrever a perda incorrida por um produto qualquer, cujo objetivo final é a redução de custos do produto para o consumidor, através da redução da variabilidade e atingindo a melhor Qualidade.

\section{David A. Garvin:}

Garvin (1992) destaca a necessidade de um melhor entendimento do termo Qualidade, para que ela possa realmente assumir um papel estratégico. Segundo ele, estudiosos de filosofia, economia, marketing e gerência de operações têm visto a qualidade sob aspectos diferentes:

- a filosofia concretiza-se nas questões de definição;

- a economia na maximização dos lucros e no equilíbrio do mercado;

- o marketing nos elementos críticos determinantes do comportamento dos compradores e na satisfação dos clientes e, 
- a gerência de operações nas práticas de engenharia e no controle da produção.

Baseando-se nesses enfoques são identificadas cinco abordagens principais para a definição de Qualidade:

- Transcendental: sinônimo de excelência nata;

- Baseada no produto: que identifica a Qualidade com os atributos e/ou ingredientes de um produto;

- Baseada no usuário: que parte da premissa de que a "Qualidade está diante dos olhos de quem observa";

- Baseada na fabricação: a Qualidade é vista como conformidade às especificações e

- Baseada no valor: definindo qualidade em termos de custos e preços.

Para Garvin (1992), o programa de análise da Qualidade (produto ou serviço) tem oito dimensões ou categorias de qualidade: desempenho, características, confiabilidade, conformidade, durabilidade, atendimento, estética e qualidade percebida. Essas categorias são estanques e distintas entre si, e permite que um produto ou serviço, com alta qualidade em uma dimensão, seja mal classificado em outra. No entanto, em muitos casos as dimensões estão interrelacionadas e a melhoria de qualidade em uma dimensão só pode ser atingida à custa de outra.

\section{Definições Oficiais}

A Sociedade Americana para o Controle da Qualidade - American Society for Quality Control (ASQC, 2000) define “Qualidade como a totalidade de características e atributos de um produto ou serviço que possuem a habilidade de satisfazer certa necessidade".

A ISO - International Standard Organization (ABNT, 2001a) define Qualidade como “grau no qual um conjunto de características inerentes satisfaz a requisitos (necessidade ou expectativa que é expressa, geralmente de forma implícita ou obrigatória)”.

Segundo Teboul (1991), a Associação Francesa de Normas - AFNOR - define Qualidade como “a capacidade de um produto ou serviço satisfazer as necessidades dos usuários” e a norma japonesa JIS-Z-8101, de 1981, considera a Gestão da Qualidade como "um sistema de meios colocados em prática para produzir economicamente produtos ou serviços que satisfarão as necessidades dos clientes". 
De um modo geral, todas essas definições colocam a qualidade como a capacidade de atender às necessidades dos clientes, do modo mais abrangente possível, maximizando a oferta e minimizando os defeitos ou erros. Tais definições cobrem os principais conceitos associados ao termo Qualidade, que neste trabalho se faz necessário, embora não esgotem o assunto.

\section{3 - A GESTÃO DA QUALIDADE}

Para serem competitivas e manterem um bom desempenho econômico, as organizações precisam, cada vez mais, adotar sistemas de Gestão da Qualidade e produtividade. Tais sistemas devem proporcionar a melhoria contínua da qualidade e o aumento da satisfação dos seus clientes e outras partes envolvidas (empregados, fornecedores e sociedade).

Crosby (1999) faz uma distinção entre Gestão da Qualidade, Garantia da Qualidade e Controle da Qualidade. A Gestão da Qualidade é a filosofia da gestão preventiva, a Garantia da Qualidade é a documentação e o Controle da Qualidade é a medição. Assim sendo, a Gestão da Qualidade determina como se gerencia uma organização.

O processo de Gestão da Qualidade é extremamente abrangente dentro da empresa, portanto, deve atingir todas as suas áreas, ou seja, o convencimento da alta administração sobre o impacto da qualidade no sucesso da empresa é fundamental para a inserção da Gestão da Qualidade na vida de qualquer organização.

Ter qualidade nos produtos e serviços ofertados no mercado é fundamental para uma empresa, porém é preciso envolver todos que nela trabalham com estímulos para que surjam "intra-empreendedores" capazes de desafiar constantemente seu "status quo". Atualmente, muitas empresas investem nas chamadas Universidades Corporativas, no intuito de desenvolver o seu pessoal com a intenção de ter potencial humano para gerar mudanças e alterações de foco, ou seja, sempre se antecipar ao mercado e às tendências, pois se até uma década atrás ter qualidade era diferencial, agora passou a ser condição necessária para as empresas serem habilitadas a concorrer. E as exigências podem vir tanto do mercado externo, como do concorrente ou do cliente. 


\subsection{1 - A Gestão da Qualidade na pequena empresa}

A pequena empresa é caracterizada por ser operacionalizada pelo proprietário, possuir poucos empregados e/ou poucos produtos ou linhas de serviços, baixo capital de giro, baixas margens de lucro, baixas despesas gerais, pequena área de atuação, conhecimento limitado de tecnologias de informação e sistemas de informação manuais.

Segundo Oliveira (1998), a pequena empresa possui uma personalidade bastante peculiar na sua gestão. A maneira de gerir o negócio está intimamente ligada à personalidade do seu principal executivo. Com relação à competitividade, suas características podem ser representadas na forma de um comparativo entre seus pontos fortes e fracos (Tabela 7).

Tabela 7 - Pontos fortes e fracos da pequena empresa

\begin{tabular}{|c|c|}
\hline Pontos Fortes & Pontos Fracos \\
\hline Arrojo, crença e obstinação pelo trabalho & $\begin{array}{l}\text { Característica gerencial autoritária e } \\
\text { centralizadora }\end{array}$ \\
\hline Agilidade nas ações e na tomada de decisões & Individualismo pelo medo da concorrência \\
\hline $\begin{array}{l}\text { Informações internas circulam com mais } \\
\text { facilidade }\end{array}$ & $\begin{array}{l}\text { Dificuldade de comunicação com o meio } \\
\text { ambiente }\end{array}$ \\
\hline $\begin{array}{l}\text { Funcionários estão mais próximos dos } \\
\text { clientes }\end{array}$ & $\begin{array}{l}\text { Visão distorcida dos recursos humanos e } \\
\text { pouco profissionalismo no atendimento aos } \\
\text { clientes }\end{array}$ \\
\hline $\begin{array}{l}\text { Melhor entendimento da organização pelos } \\
\text { funcionários }\end{array}$ & $\begin{array}{l}\text { Empregos menos vantajosos para os } \\
\text { trabalhadores }\end{array}$ \\
\hline Mão de obra com utilização otimizada & $\begin{array}{l}\text { Falta de pessoal qualificado para tarefas } \\
\text { específicas e sobrecarga de trabalho }\end{array}$ \\
\hline Funcionários mais generalistas & Poucos investimentos em treinamentos \\
\hline $\begin{array}{l}\text { Adaptabilidade maior em relação às } \\
\text { mudanças de mercado }\end{array}$ & $\begin{array}{l}\text { Baixo poder de barganha em relação à } \\
\text { contratação de empréstimos }\end{array}$ \\
\hline Flexibilidade de adaptação ao mercado & $\begin{array}{l}\text { Capacidade de produção limitada e em baixa } \\
\text { escala }\end{array}$ \\
\hline
\end{tabular}

Para Juran e Gryna (1991), as pequenas empresas estão potencialmente em melhor posição para atingir uma estratégia de satisfação do cliente, pois:

- o âmbito do negócio é limitado a um nicho que envolve uma linha de produtos relativamente pequena;

- $\quad$ as ações de qualquer gerente (portanto) têm impacto sobre poucos clientes;

- a organização tem menos departamentos funcionais; 
- muito do planejamento multifuncional acontece no cérebro dos indivíduos;

- a organização tem poucos níveis hierárquicos;

- os gerentes de nível hierárquico mais alto estão próximos da ação que acontece a nível operacional,

- o número total de gerentes é menor, simplificando, assim, o trabalho de comunicação e coordenação.

Considerando que cada processo de implantação de um sistema de Gestão da Qualidade seja um caso específico, então para a pequena empresa, os elementos do sistema de gestão devem ser adaptados à sua realidade. A diferença de tamanho da pequena empresa tende a influenciar significativamente tanto na implantação como nos resultados, pois, elas operam com menor formalidade e sistematização que as grandes empresas.

As pequenas e médias empresas, em geral, também apresentam algumas situações que podem dificultar a implantação de Sistemas da Qualidade, tais como:

- geralmente são familiares, e os problemas são tratados de forma não profissional;

- possuem estrutura desorganizada, pois cresceram de forma desordenada;

- são extremamente informais;

- dispõem de poucos recursos para investimentos;

- não possuem controle de custos eficiente,

- imaginam qualidade como algo de alto custo e difícil de obter.

A Gestão da Qualidade é imprescindível para o desenvolvimento empresarial, e para acontecer é necessário que existam objetivos e metas a serem comparadas aos resultados, bem como ferramentas de controle operacional, gerencial e estratégico para o posicionamento das informações necessárias. Sendo assim, é preciso que a pequena empresa se organize, planeje e estabeleça os resultados que quer atingir e trabalhe para atingi-los.

Em síntese, a pequena empresa estará trabalhando pró-ativamente quando os gestores se utilizarem das ferramentas de controle que permitam visão de futuro, forneçam parâmetros para decidirem com clareza e, assim, garantirem a qualidade. 


\subsection{2 - Sistemas da Qualidade}

Um sistema é um conjunto organizado de regras e ações composto de várias partes (subsistemas), que trabalham de forma harmônica para atender a um objetivo comum para o qual foi criado.

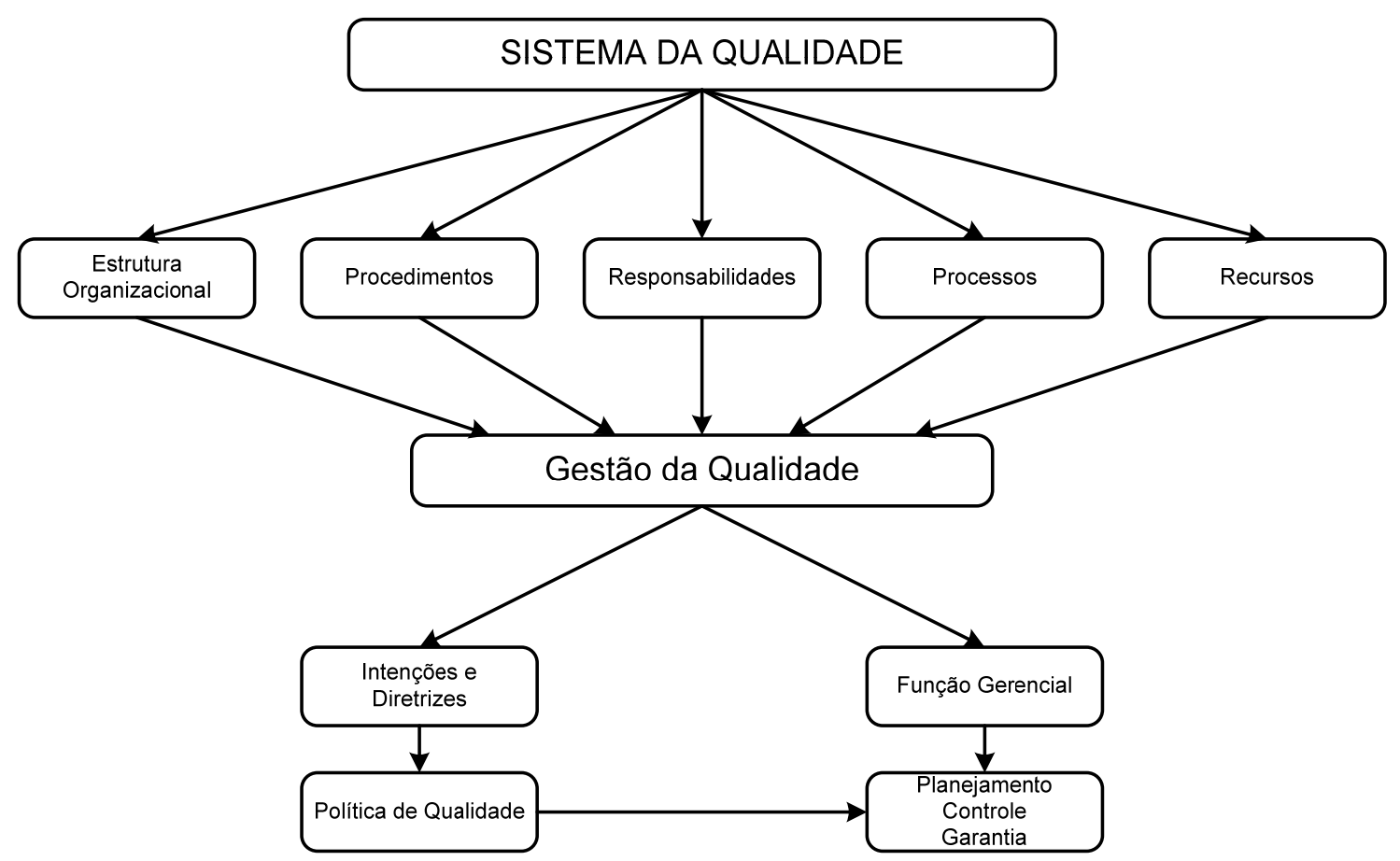

Figura 21 - Exemplo de como é composto um Sistema da Qualidade.

Fonte: Reis et. al., 1995

A qualidade influencia todas as demais funções da organização e também é influenciada por todas elas, logo, é considerada uma função sistêmica e conseqüentemente precisa de um sistema para que funcione bem, denominado de Sistema da Qualidade (Figura 21).

Um sistema de Gestão da Qualidade pode então ser definido como um conjunto de recursos e regras mínimas, implementado de forma adequada, cujo objetivo é orientar cada parte da empresa de como executar de maneira correta e no tempo devido a sua tarefa, estando todas em harmonia e direcionadas para o objetivo comum da empresa: ser competitiva - ter qualidade com produtividade (MARANHÃO, 2001). Em um sistema de Gestão da Qualidade é preciso também que as pessoas estejam motivadas, e esse novo desafio pode ser conseguido com a implementação da forma já popularizada conhecida como Qualidade Total (TQM, TQC, CWQC etc.), assim denominada porque combina as atividades de execução dos processos do sistema com o comportamento adequado das pessoas em todas as atividades da empresa. 
O caminho para se chegar à Qualidade Total é longo e exige muita persistência e determinação da alta administração da empresa. O comprometimento da força de trabalho é um fator fundamental para se alcançar a Qualidade Total. Pode-se dizer que nenhuma definição de Gestão da Qualidade Total é universalmente aceita. As diversas definições incluem elementos comuns, como satisfação do cliente, delegação de autoridade ao trabalhador, melhoria contínua, e assim por diante. A Norma NBR ISO 8402:1994 (ABNT, 1994) define Gestão da Qualidade Total como:

“A Gestão da Qualidade Total é, essencialmente, um modo de gerir uma organização centrada na qualidade, baseada na participação de todos os seus membros, visando o sucesso em longo prazo, através da satisfação do cliente e dos benefícios para todos os membros da organização e para a sociedade”.

Para Crosby (1999), três elementos são essenciais para o êxito de qualquer programa da qualidade:

a) um sistema de instruções escritas (define como cada atividade deve e ser executada);

b) a integridade pessoal dos elementos responsáveis por fazer funcionar o sistema e,

c) equipe de gerência crente no Zero Defeito como único padrão viável de desempenho.

Um Sistema de Gestão da Qualidade é composto então por uma coletânea de documentos organizados segundo uma determinada ordem de prioridade da organização, denominado sistema de documentação, e tem por objetivo padronizar os documentos para facilitar a implantação da Gestão da Qualidade. A documentação da Qualidade está subdividida em vários níveis (Figura 22): o Manual da Qualidade considerado documento de primeiro nível, os procedimentos considerados de segundo nível e as Instruções de Trabalho, Métodos de Análise e Registros da Qualidade considerados documentos de terceiro nível (REIS, 1995).

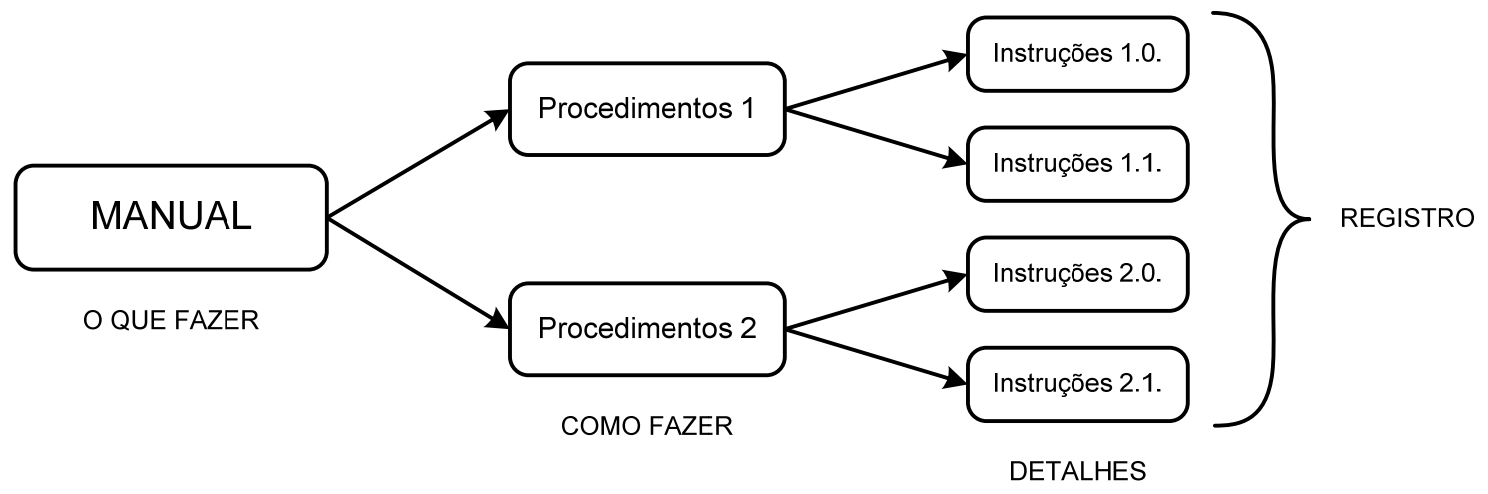

Figura 22 - Documentos da Qualidade

Fonte: Reis et. al., 1995 
A estrutura do Sistema da Qualidade é habitualmente apresentada em forma de pirâmide para evidenciar a hierarquia dos documentos que fazem parte do sistema. Os níveis da pirâmide apresentam as definições de “quem”, “o que”, “quando” e “como” as atividades ocorrem. No topo da pirâmide (Figura 23) está o Manual da Qualidade que mostra a estrutura geral (políticas e diretrizes) de como funciona o sistema, sendo considerado o “nível estratégico das atividades voltadas para a qualidade”.

No nível intermediário da pirâmide estão os procedimentos que descreve “quem”, “o que” e "quando" se produz (em algumas situações quando um procedimento é suficientemente abrangente, pode ser dispensada a elaboração de instruções de trabalho). Este nível é definido como "nível tático do sistema”.

$\mathrm{Na}$ base da pirâmide ficam os demais documentos complementares do Sistema da qualidade. Neste nível são classificadas as instruções de trabalho que descrevem “como" as atividades são executadas e quais documentos (registros) que comprovam o atendimento aos requisitos especificados. É o nível operacional do sistema.

A partir da observação dessa estrutura, nota-se uma interdependência entre os níveis do sistema. Alguns níveis são normativos (primeiro e segundo), e o último é também comprobatório porque, além de estabelecer como as atividades acontecem, ainda comprova o funcionamento do sistema.

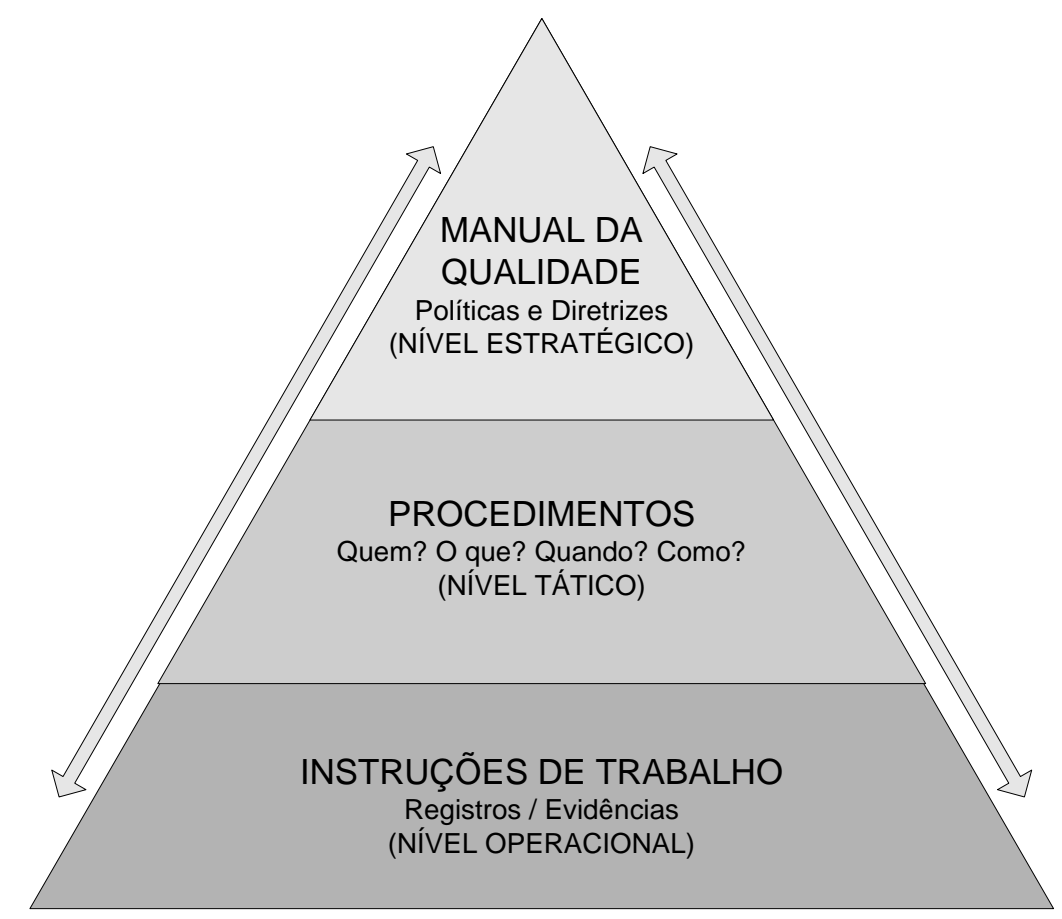

Figura 23 - Estrutura do Sistema da Qualidade. 
Além desses documentos, as organizações processam ainda outros tipos de documentos (recebidos ou expedidos) característicos de seu negócio, tais como:

- comunicação interna (memorandos, comunicação interna etc.);

- comunicação externa (normas, cartas, ofícios, portfólios etc.),

- gestão geral (planos, relatórios, contratos etc.).

Esses documentos podem e devem ter tratamentos previstos no Sistema de Gestão da Qualidade, formalizando assim todo o acervo documental da empresa.

Resumindo, se é possível dizer que existe um sistema perfeito, o resultado será um produto perfeito. A qualidade de um produto ou serviço não é só o resultado provocado pelas pessoas que fazem o produto ou serviço, e sim o resultado do sistema dentro do qual elas trabalham.

\subsection{3 - Implantação de sistemas da qualidade}

A implantação de um Sistema da Qualidade representa uma forte mudança cultural que, em geral, provoca conflitos. Por isso, só uma firme definição da alta administração (postura firme) fornecendo todo o apoio (na conscientização da necessidade de mudanças e na tomada de decisões) necessário poderá superar as resistências à implantação.

As mudanças para a implantação de um Sistema da Qualidade envolvem a estrutura técnica, e principalmente a estrutura organizacional, ou seja, mudanças tecnológicas (máquinas, materiais, processos e sistema), humanas e sociais (cultura, educação, ambiente social, personalidade, etc.), sendo esta vital para a implantação eficaz do Sistema da Qualidade em qualquer empresa.

A implantação de Sistemas da Qualidade em empresas industriais e de serviços tem crescido bastante nos últimos tempos, acompanhando a necessidade das empresas que buscam uma certificação, seja por interesse próprio, por exigência contratual ou por razões técnicas. Os Sistemas da Qualidade não possuem uma metodologia única de implantação, possibilitando às organizações conduzi-la por diversos modos e diversos caminhos. A própria literatura sobre o assunto é vasta e nem sempre convergente. 
Dos diversos modelos de Sistemas da Qualidade existentes, o mais aceito e adotado em todo o mundo, devido a sua simplicidade e eficácia, é o proposto pelas normas da série ISO 9000, que no Brasil são denominadas NBR ISO 9000. Trata-se de um sistema normativo internacional de Gerência da Qualidade (assegurado) com a característica peculiar de poder se adequar a qualquer tipo de organização.

Este modelo fundamentalmente diz o que deve ser feito, e não como deve ser feito. A parte de como fazer, deve levar em consideração a cultura da empresa, por meio do estabelecimento de métodos e ações que possam ser facilmente incorporados à sua rotina. Embora cada processo de implantação seja um caso específico, é possível padronizar algumas ações que norteiem tais implantações e que levem em consideração as especificidades e características próprias de cada organização, ou seja, o que deu certo em uma empresa pode não obrigatoriamente dar certo em outra.

Segundo Oliveira (1998), apesar das diferentes formas de abordagem ou metodologias disponíveis que visam implantar um Sistema da Qualidade com base nas normas da série NBR ISO 9000, os seguintes pontos de vista convergentes podem ser registrados:

- importância do perfil do gerente da qualidade para o sucesso da implantação de um Sistema da Qualidade. Dentro desse perfil algumas características são consideradas comuns pelos autores: conhecimento técnico acerca de qualidade e conseqüentemente dos requisitos para implantação da NBR ISO 9000;

- bom relacionamento humano para permitir a negociação e interação com todos os setores da empresa;

- necessidade do comprometimento da alta administração da empresa para a obtenção da certificação ISO 9000;

- definição de um planejamento ou metodologia de implantação a ser seguido durante todo o processo;

- descrições detalhadas, muitas delas com exemplos em anexos, da elaboração da documentação do Sistema da Qualidade, ressaltando, assim, a importância da formalização requerida pela norma NBR ISO 9000,

- relevância dada à necessidade de uma metodologia ou planejamento para a implantação de um Sistema da Qualidade. 
MARANHÃO (2001) transcreve e interpreta os requisitos da norma NBR ISO 9001 e descreve em detalhes a elaboração da documentação do Sistema da Qualidade, inclusive do Manual da Qualidade. Para implementação de um Sistema da Qualidade com base na norma NBR ISO Série 9000, o autor apresenta os seguintes passos:

- convencimento da direção;

- $\quad$ escolha do coordenador de implementação (gerente do projeto);

- avaliação da situação atual (diagnóstico);

- elaboração do cronograma de trabalho;

- planejamento estratégico;

- unificação conceitual nos vários níveis;

- definição e mapeamento de processos;

- formação e implementação dos grupos de trabalho;

- a primeira "vassourada" (housekeeping);

- elaboração do Manual da Qualidade;

- elaboração e implementação dos demais documentos;

- finalidade, organização e controle dos registros (da qualidade);

- implementação do Manual da Qualidade;

- realização de auditorias internas da qualidade;

- treinamento de suporte;

- implementação do processo de análise e melhoria;

- pré-auditoria (pre-assessment);

- auditoria de certificação;

- manutenção do Sistema de Gestão da Qualidade;

Segundo Toledo e Martins (1998), a crescente importância da Gestão da Qualidade como fonte de vantagem competitiva, tem levado várias organizações (de manufatura e de serviços) a um maior esforço para implantação. No entanto, muitas acabam falhando e transmitindo decepções e desconfiança com relação a real efetividade do sistema. Entre as possíveis causas do insucesso os autores apontam:

- planejamento inadequado e plano de implementação insuficientes ou falhos;

- falta de um modelo de referência para a Gestão da Qualidade;

- ênfase na imagem e não nos resultados;

- foco em padrões mínimos já existentes;

- não alinhamento com objetivos estratégicos e

- descontinuidade do programa. 
E nesse contexto, os autores propõem um modelo para elaboração de programas de Gestão para Qualidade Total com a intenção de subsidiar os profissionais que trabalham com a Gestão da Qualidade. O modelo consiste sumariamente do seguinte:

\section{Definições das informações de entrada contendo:}

- informações do ambiente interno;

- informações do ambiente externo;

- informações sobre o conhecimento científico e tecnológico para Gestão da Qualidade através de:

o verificação das estratégias e políticas da organização;

o identificação das metodologias e ferramentas da Gestão da Qualidade o adoção de um modelo de referência.

\section{Definição do conteúdo do Programa de Gestão com as seguintes informações:}

- pressupostos e princípios básicos;

- diretrizes e metas;

- indicadores de desempenho e marcos de avaliação;

- subprogramas;

- ações, prazos e responsabilidades,

- orientação quanto à implementação, acompanhamento e avaliação.

\section{Definição da amplitude de ação do Programa de Gestão}

- área de Sistema da Qualidade;

- área de mobilização, comunicação e capacitação dos recursos humanos;

- área de melhoria contínua.

\section{Tratamento das informações de entrada do Programa de Gestão}

Efetuada através do confronto entre a situação atual e a futura desejada que resultará na melhoria que será realizada e traduzida em objetivos para desencadear ações. A escolha das ações prioritárias deve ser feita com referência à estratégia e ás políticas da organização, levando-se em conta as relações de causa e efeito em um sentido mais amplo e considerando as que produzirão melhores resultados. 
Recomenda-se ainda que as ações do programa de Gestão da Qualidade Total sejam detalhadas utilizando a abordagem do 5W 1H, ou seja, why (por que), what (o que), when (quando), who (quem) where (onde) e how (como) e que os trabalhos sejam feitos por uma equipe multidisciplinar capacitada e participativa, e, quando necessário, com apoio de consultores externos à organização.

\section{4 - O MODELO ISO 9000 DE SISTEMA DA QUALIDADE}

\subsection{1 - Generalidades}

ISO significa International Organization for Standardization, trata-se de um órgão com sede na Suíça, fundado em 1947 para desenvolver um conjunto de normas para manufatura, comércio e comunicação na Europa. No final de 2003 contava com 148 países membros.

O objetivo das normas da série ISO 9000 é estabelecer normas técnicas que representem e traduzam o consenso de diferentes países do mundo. Estas normas estabelecem todo direcionamento para implantação de um Sistema da Qualidade. Sua grande ênfase é a documentação, pois assim é possível corrigir as imperfeições e limitações do ser humano (a memória está sujeita a falhas e o homem não é eterno), além disso, o homem é circunstancial e reage de acordo com o momento.

No Brasil, a ABNT (Associação Brasileira de Normas Técnicas) é o representante oficial da ISO e o órgão responsável pela distribuição da norma no país, com o titulo NBR ISO 9000. Os padrões técnicos criados pela ISO são aceitos internacionalmente para minimizar as barreiras tecnológicas que limitavam as transações comerciais em todo o mundo.

As normas da série ISO 9000 não se referem a um determinado produto ou processo, o que possibilita sua aplicação a todos os tipos de empresas seja de pequeno, médio ou de grande porte, fabril ou de serviços. Embora a ISO 9000 especifique quais os requisitos que um Sistema da Qualidade deve contemplar, ela não estabelece como eles devem ser implantados, dando maior flexibilidade e compatibilidade a qualquer ramo de atividade. 
A primeira edição da norma série ISO 9000 foi publicada em 1987 através do comitê TC 176 (tomando como base a norma inglesa BS 5750 publicada em 1979). A segunda edição foi em 1994 (primeira revisão) e a terceira edição em 2000 (segunda revisão). Em sua revisão atual (2000) as quatro normas primárias NBR ISO 9000 compôe:

- NBR ISO 9000:2000, válida a partir de 29.01.2001 (cancelou e substituiu as anteriores NBR ISO 8402; NBR ISO 9000-1 e NBR ISO 9000-2). Descreve os fundamentos de sistema de Gestão da Qualidade e estabelece a terminologia para estes sistemas.

- NBR ISO 9001:2000, válida a partir de 29.01.2001 (cancelou e substituiu as anteriores NBR ISO 9002; NBR ISO 9003, e substituiu a anterior NBR ISO 9001). Especifica requisitos para um sistema de Gestão da Qualidade e objetiva aumentar a satisfação do cliente.

- NBR ISO 9004:2000, válida a partir de 29.01.2001 (cancelou e substituiu as normas anteriores NBR ISO 9004-1; NBR ISO 9004-2 e NBR ISO 9004-3). Fornece diretrizes que consideram tanto a eficácia como a eficiência do sistema de Gestão da Qualidade. O objetivo desta norma é melhorar o desempenho da organização e a satisfação dos clientes e das outras partes interessadas.

- NBR ISO 19011:2002, válida a partir de 29.12.2002. (substituiu as normas NBR ISO 10011-1; NBR ISO 10011-2; NBR ISO 10011-3; NBR ISO 14010; NBR ISO 14011 e NBR ISO 14012). Fornece diretrizes sobre auditoria de sistemas de Gestão da Qualidade e/ou Ambiental.

Juntos esses documentos formam um conjunto coerente de normas sobre sistema de Gestão da Qualidade que facilita a compreensão mútua no comércio nacional e internacional.

A nova ISO 9000:2000 busca evidenciar os processos e não os requisitos. Seu ponto de destaque é sem dúvida a abordagem por processo, cuja vantagem é o controle contínuo que ela permite sobre a ligação entre os processos individuais, bem como sua combinação e interação dentro do sistema de Gestão, com a finalidade de alcançar objetivos específicos da qualidade. A abordagem por processos aplicada num Sistema de Gestão da Qualidade, enfatiza: 
- entendimento e atendimento dos requisitos;

- $\quad$ necessidade de considerar os processos em termos de valor agregado;

- obtenção de resultados de desempenho e eficácia do processo;

- melhoria contínua de processos baseada em medições objetivas.

A norma NBR ISO 9001:2000 (ABNT, 2001b) também faz referência à utilização do método de melhorias PDCA como forma de gerenciar processos e descreve o método de melhorias em questão, como parte integrante do seu Sistema de Gestão da Qualidade.

O método de melhorias PDCA é derivado do ciclo de controle estatístico do processo desenvolvido por Walter A. Shewhart na década de 30 e popularizado por William E. Deming a partir da década de 50, como Ciclo PDCA (Figura 24).
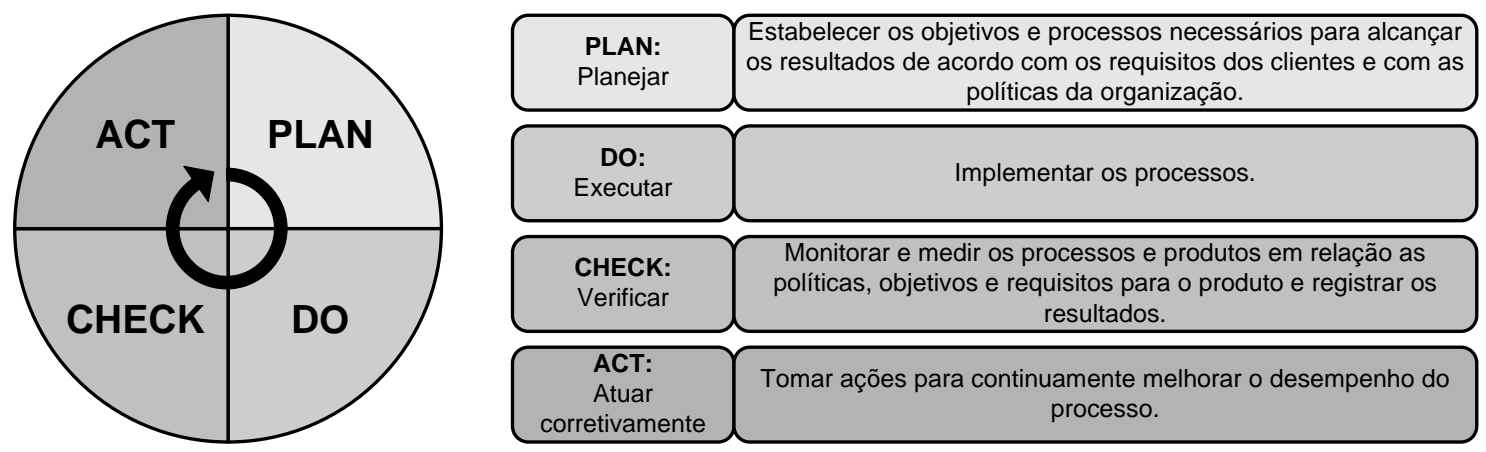

Figura 24 - O Ciclo PDCA

O conceito de PDCA está presente em todas as áreas sendo usado continuamente, formal ou informal, consciente ou inconsciente em tudo que se faz. Qualquer atividade, seja ela simples ou complexa, pode ser gerenciada por meio deste conceito. No contexto de sistema de Gestão da Qualidade, o PDCA é um ciclo dinâmico que pode ser desdobrado dentro de cada processo da organização bem como no sistema de processos em sua totalidade. Está intimamente ligado ao planejamento, implementação, controle e melhoria contínua dos processos de realização de produtos e serviços e do Sistema de Gestão da Qualidade, com ação em todos os níveis da organização.

Com a nova revisão da ISO 9000 (2000), as organizações terão ainda mais flexibilidade para selecionar as estruturas e os métodos de documentação apropriados para as suas necessidades. A extensão da documentação do SGQ depende da situação da organização e deve incluir, no mínimo, uma combinação apropriada dos seguintes documentos: 
- documentos que descrevam a política da qualidade;

- o Manual da Qualidade (descrevendo a interação dos processos no Sistema de Gestão da Qualidade). A ISO 9001:2000 exige que a organização tenha um Manual da Qualidade e que esse atenda a determinados requisitos;

- procedimentos documentados que descrevam o sistema (podem ser incluídos no Manual da Qualidade). A ISO 9001:2000 exige apenas seis "procedimentos documentados", porém a organização deve ter também a documentação dos processos principais do sistema e de suas interações, ou seja, após definidos os processos do sistema geral da qualidade e estabelecidas suas interações, convém descrever os processos principais em procedimentos documentados,

- os procedimentos de coordenação (de fácil entendimento) junto com o Manual da Qualidade, que fornecem um mecanismo de comunicação dos processos à organização ajudando a garantir que todos os funcionários estejam compreendendo as metas a serem alcançadas.

De um modo geral, o novo padrão visa muito mais à satisfação do cliente do que ao padrão antigo e enfatiza mais a necessidade de fazer melhorias. Entre as principais vantagens da nova versão ISO 9000/2000 têm-se:

- maior ênfase na melhoria contínua e na monitoração da satisfação do cliente;

- linguagem mais clara, de fácil compreensão e utilização pelo usuário;

- maior integração entre a norma contratual e a orientativa;

- melhor adaptação a todos os tipos de organização, independente do campo de atuação e tamanho;

- mais apropriado ao setor de serviços,

- maior compatibilidade com outros sistemas de gerenciamento, como as normas da série NBR ISO 14000 (Sistema de Gestão Ambiental).

\subsection{2 - Princípios de Gestão da Qualidade}

Um princípio de Gestão da Qualidade é uma crença ou regra fundamental e abrangente para conduzir e operar uma organização, que visa melhorar continuamente seu desempenho a longo prazo, pela focalização nos clientes e, ao mesmo tempo, encaminhar as necessidades de todas as partes (ABNT, 2001a). As normas ISO 9000:2000 e ISO 9004:2000 apresentam oito princípios de Gestão da Qualidade: 
1. Foco no cliente - as organizações devem entender que dependem de seus clientes, devendo, desta forma, entender suas necessidades atuais e futuras, atender a estas necessidades e buscar sempre excedê-las.

2. Liderança - líderes devem estabelecer propósitos e diretrizes únicas para a organização, criando ambientes nos quais as pessoas estejam plenamente envolvidas em alcançar os objetivos da organização.

3. Envolvimento das pessoas - pessoas são a essência de uma organização e seu completo envolvimento garante a utilização de suas habilidades na busca do máximo benefício para a organização.

4. Abordagem de processo - os resultados desejados são mais eficientemente atingidos quando os recursos e atividades relacionadas são tratados como processos.

5. Abordagem sistêmica - a identificação, entendimento e gerenciamento de um sistema de processos inter-relacionados contribuem para a efetividade da organização.

6. Melhoria contínua - objetivo permanente da organização.

7. Abordagem factual para a tomada de decisão - decisões efetivas são tomadas através da análise lógica ou intuitiva de informações e dados.

8. Benefícios mútuos nas relações com os fornecedores - a capacidade da organização e de seus fornecedores em agregar valor é maximizada quando existem relações de benefício mútuo.

\subsection{3 - Escopo do Sistema de Gestão da Qualidade}

O escopo do SGQ é definido pela ISO como alcance, extensão ou raio de ação, propósito principal, intenção que define a abrangência do sistema, ou seja, os processos que serão cobertos durante sua certificação (auditoria) tais como: projeto, produção ou linha especifica de produto ou serviço (MELLO et.al., 2002). Em uma organização, o escopo adotado em sua totalidade ou com limitações, deve estar claramente definido no Manual da Qualidade da organização para evitar confusões ou má interpretação por parte dos clientes e usuários finais.

A implementação de um Sistema da Qualidade com base nas normas ISO 9000:2000 deve, de preferência, contemplar todos os requisitos da norma que são aplicáveis aos seus produtos e serviços dentro do escopo de seu SGQ, com exceção daqueles que não são aplicáveis, devido à natureza da organização e da realização de seus processos. 
Outro fator importante na definição do escopo da organização é a inclusão dos processos adquiridos externamente (terceirizados) que, conforme o requisito 4.1 da seção 4 da norma ISO 9001:2000 (ABNT, 2001b), estabelece:

“Quando uma organização optar por adquirir externamente algum processo que afete a conformidade do produto em relação aos requisitos, a organização deve assegurar o controle desses processos os quais devem ser identificados no SGQ”. 


\section{5 - PROCEDIMENTOS METODOLÓGICOS}

O procedimento metodológico adotado neste trabalho é conhecido como pesquisa-ação e possui cunho social em que o pesquisador desempenha um papel ativo na transformação de determinada situação, por meio da interação com a comunidade, grupo, setor ou instituição. Segundo Thiollent, (2002, p 14):

\footnotetext{
"Pesquisa-ação é um tipo de pesquisa social com base empírica que é concebida e realizada em estreita associação com uma ação ou com a resolução de um problema coletivo e no qual os pesquisadores e os participantes representativos da situação ou problema estão envolvidos de modo cooperativo ou participativo.”
}

O pesquisador levanta os problemas, analisa-os, propõe alternativas e encaminha-os na forma de soluções. Porém, é importante ressaltar que os procedimentos metodológicos adotados não são estanques, ou seja, se há um problema, esse deve ser cientificamente investigado, elaborado e concluído ou, pelo menos, esclarecido. Neste trabalho foram adotadas as seguintes fases:

- identificação do problema;

- revisão da literatura sobre os assuntos envolvidos (GPS, Empresas, processos e Sistemas de Gestão da Qualidade);

- pesquisa social (independente) comprobatória da situação das empresas de posicionamento com GPS no Brasil;

- caracterização de uma empresa de GPS genérica e de seus principais processos operacionais (mapeamento);

- elaboração de um modelo para Gestão da Qualidade referente ao caso da empresa genérica. 


\section{1 - IDENTIFICAÇÃO DO PROBLEMA}

A observação do problema se deu a partir de relatos de situações cotidianas vivenciadas por pequenas empresas e profissionais liberais, relacionados com a questão de como garantir a qualidade na prestação dos serviços de posicionamento com o sistema GPS. Entre os relatos, os mais comuns eram:

- “... às vezes a realização de um serviço aparentemente simples, provoca uma tremenda "dor de cabeça”, pois são horas de retrabalho, consultas a especialistas $e$ parece que tudo dá errado, sem falar nos custos extras...”

- “... os principais contratantes desse tipo de serviço começaram a exigir, para participação nas licitações, que as empresas e os profissionais comprovassem sua capacitação e também a de seus fornecedores com relação à qualidade dos serviços prestados...”

- “... os bancos e financiadoras também, para liberação de empréstimos, têm exigido atestados que comprovem a capacitação técnica e uma certificação de qualidade..."

Alguns desses casos muitas vezes são resolvidos com grandes custos e às vezes nem assim. Tal situação levou o autor a propor uma solução mais ampla e diferente das costumeiras que servem apenas como paliativos e normalmente são momentâneas. A proposta inicial era desenvolver apenas mecanismos para garantir a qualidade dos serviços, porém ao aprofundar os estudos na área de qualidade, verificou-se que tais mecanismos já existem e precisavam apenas ser aplicados, adaptados ou corrigidos.

A proposta foi então desenvolver uma solução “mais profunda” de caráter empresarial, baseada nos moldes das soluções adotadas por empresas do setor de manufatura, que consiste na implementação de um Sistema de Gestão da Qualidade envolvendo toda a estrutura técnica e organizacional. Sua finalidade é orientar cada parte da empresa na execução correta de sua tarefa no devido tempo e em harmonia com as outras, sendo todas elas voltadas para o objetivo comum da empresa de ser competitiva, isto é, ter qualidade com produtividade.

A ausência de material especifico sobre o papel da qualidade em uma organização empresarial da área de posicionamento com GPS, seus reflexos nas ações e as influências no produto final, também foi um dos motivadores para o desenvolvimento desse trabalho. 


\section{2 - REVISÃO DA LITERATURA}

A pesquisa bibliográfica realizada compreendeu principalmente dois temas: o Sistema de Posicionamento Global - GPS e a Gestão da Qualidade. Porém, é importante ressaltar que, na revisão destes dois temas, não foi encontrado qualquer estudo ou material (disponível) que relacionasse juntos os dois temas. Daí a necessidade da realização de uma revisão bibliográfica mais abrangente, principalmente sobre a Gestão da Qualidade e suas características com relação às aplicações em organizações de serviços, que envolvesse os principais conceitos e pontos de vista dos principais autores. Além desses dois principais assuntos, outros também necessários para o desenvolvimento desta tese foram pesquisados, estudados e aplicados, tais como pesquisa social, desenvolvimento de "home-page" para aquisição de dados, sistema de banco de dados, tratamento e processamento de dados, desenvolvimento e modelagem de processos e empresas.

O material usado constituiu-se principalmente em fontes de papel ou arquivos digitais obtidos de publicações avulsas, revistas, livros, monografias, dissertações, teses, anais de congressos, relatórios de pesquisa, home-pages, além de outras informações obtidas de materiais e notas de aulas dos cursos de formação realizados pelo autor. Os resultados da pesquisa bibliográfica serviram de orientação para o desenvolvimento desta tese em todas as suas fases, incluindo a elaboração de um modelo para a Implantação da Gestão da Qualidade em uma empresa genérica de posicionamento com o sistema GPS.

\section{3 - PESQUISA SOBRE AS EMPRESAS DE GPS NO BRASIL}

Trata-se de uma pesquisa social que foi realizada com a finalidade de caracterizar a situação das empresas prestadoras de serviços de posicionamento com o sistema GPS no Brasil, relacionada com a questão da qualidade dos serviços prestados e as formas de Gestão Organizacional usadas.

O método usado para coletar as informações (dados) dos prestadores de serviços de posicionamento com o sistema GPS é caracterizado no meio científico como “survey”3,

\footnotetext{
${ }^{3}$ Termo de origem inglesa sem correspondente preciso em português. É comumente traduzido como posicionamento.
} 
também é conhecido como plano de enquetes. É uma modalidade de pesquisa cientifica baseada na coleta de informações de populações ou amostra de populações por meios sistemáticos tais como questionários ou entrevistas. O método "survey” apresenta uma classificação quanto ao motivo ou objetivo básico (descritivo, explicativo e exploratório) e quanto ao momento de aplicação no tempo (transversal e longitudinal) (RICHARDSON, 1999). No caso desta tese, a pesquisa social que foi realizada é caracterizada como um "survey” exploratório de corte transversal, ou seja, utilizou-se um questionário semi-estruturado, com uma amostra representativa intencional em um dado momento de tempo.

O questionário foi elaborado a partir do modelo conceitual para o qual se destinava à pesquisa, e neste caso a questão da Gestão da Qualidade na organização. Outras informações de ordem geral sobre os serviços prestados também foram aplicadas.

\subsection{1 - Questionário}

As informações foram obtidas através de um questionário fechado submetido às empresas por meio de uma mensagem de correio eletrônico - e-mail (Apêndice A), que continha um “link” para preenchimento do questionário “on-line”. A opção pelo questionário eletrônico baseou-se nas vantagens particularmente relevantes para a realização dessa pesquisa (MEDEIROS, 2000): maior facilidade de preenchimento; maior facilidade de interpretação, codificação e tabulação; possibilidade de ampla abrangência geográfica e tempo relativamente curto para coleta.

Apesar do método ser o mais vantajoso e viável, ele também apresenta algumas desvantagens como, por exemplo, a impossibilidade de maior profundidade na exploração.

\subsection{2 - Representatividade da amostra}

Como se sabe, a seleção da amostra afeta o grau com que os dados podem ser generalizados para a população. No caso deste trabalho houve dificuldade (por motivos de tempo, recursos e informações disponíveis) de conseguir uma amostra probabilística de empresas que prestam os serviços de posicionamento com o sistema GPS no Brasil. Assim sendo, recorreu-se a uma amostra intencional de empresas (utilizada em situações nas quais o universo é praticamente desconhecido) (KERLING, 1980), 
totalizando (105) das 120 selecionadas a partir de guias de empresas da Revista Infogeo (INFOGEO, 2002), do Portal eletrônico Fator GIS (FATORGIS, 2003) e outras conhecidas ou indicadas pelos colaboradores. Por esse motivo, esta pesquisa social não permite que os resultados obtidos sejam totalmente generalizados para a população de empresas prestadoras de posicionamento com GPS no país, e sim para um universo intencional correspondente às empresas pesquisadas. O período de realização da pesquisa foi de novembro de 2003 a março de 2004.

\subsection{3 - Tratamento dos dados da pesquisa social}

Conforme mencionado anteriormente, as informações fornecidas pelas empresas pesquisadas foram preenchidas “on-line” em uma home-page elaborada especialmente para a pesquisa social. Todas as informações submetidas foram armazenadas com segurança em um banco de dados dinâmico integrado à home-page para posterior análise (ambos os sistemas foram desenvolvidos pelo autor e previamente testados).

O tratamento e a tabulação dos dados para melhor aproveitamento na tese foram feitos através de técnicas de estatística descritiva, com a geração de gráficos, distribuição de freqüências e relatórios. Os resultados são apresentados no Apêndice B. Para realização da pesquisa social foram usados os seguintes recursos computacionais disponibilizados no Departamento de Transportes EESC - USP:

- Hardware: Um computador servidor (www e periféricos) conectado à rede USP onde foi disponibilizada a página do questionário virtual na internet;

- Softwares: Pacotes licenciados: Dreamweaver MX e Microsoft FrontPage usados para elaboração da home-page e das conexões (via rede) ao banco de dados; Microsoft Access, usado no desenvolvimento e implantação do banco de dados (armazenar as informações submetidas pelos pesquisados via internet); Microsoft Excel e StatSoft Statistica usados como apoio no tratamento e compilação dos dados e na elaboração dos resultados da pesquisa social.

O conhecimento de informática (TI) do autor tanto em hardware como em software (redes, banco de dados e tratamento estatístico) foi fundamental para o êxito da pesquisa, que contou também com o apoio básico e a experiência do setor de informática do Departamento de Transportes da Escola de Engenharia de São CarlosUSP. 


\section{4 - A EMPRESA GENÉRICA DE SERVIÇOS COM GPS}

No desenvolvimento do modelo para implantação da Gestão da Qualidade em uma empresa de posicionamento com GPS, seria de grande valor uma parceria com alguma organização típica, pois o envolvimento real proporcionaria maior credibilidade ao modelo, uma vez que seria desenvolvido, aplicado e acompanhado em todas as etapas. Por motivos alheios a nossa vontade, essa hipótese não foi possível ser concretizada. A principal razão foi a ausência, na época, de uma empresa do ramo na cidade de São Carlos (local da pesquisa), tendo em vista, principalmente, o tempo e a disponibilidade de recursos do pesquisador para realização deste trabalho.

Assim sendo, optou-se por desenvolver um programa de Gestão da Qualidade para uma empresa fictícia, que apresentasse características semelhantes à maioria das pequenas e médias empresas prestadoras de serviços de posicionamento com o sistema GPS no Brasil, que aqui foi denominada de empresa genérica. Os dados para elaboração da empresa genérica foram coletados principalmente nos questionários da pesquisa social, em algumas entrevistas com empresários do setor, além de informações junto ao SEBRAE.

O primeiro passo foi obter os elementos necessários para a caracterização da empresa genérica, mostrados no item 3.4. Após obter as informações básicas (praticamente semelhantes em quase todas as empresas pesquisadas), partiu-se para as informações mais especificas com relação à gestão organizacional. A contribuição foi relativamente “pobre”, pois, a maioria das empresas consultadas adota sistemas informais sem qualquer controle documental.

Diante de tal situação e das dificuldades em obter informações documentadas das organizações, adotou-se a empresa genérica como norteadora (contendo apenas as informações e considerações básicas). A partir delas foram desenvolvidos e considerados os principais processos organizacionais que estão envolvidos na produção dos serviços relacionados aos posicionamentos com GPS e a proposta do modelo de Gestão da Qualidade (Capitulo 6). 


\section{5 - ELABORAÇÃO DO PROGRAMA (MODELO) DE GESTÃO DA QUALIDADE}

Esta fase de elaboração do Programa de Gestão da Qualidade teve como referência as principais recomendações propostas por Toledo e Martins (1998) (Figura 25), conforme mencionados no item 4.3.3. A área de ação neste trabalho foi definida como Sistemas da Qualidade, ou seja, foram enfatizadas as ações para formalizar os procedimentos de Garantia da Qualidade e para manter os padrões de desempenhos esperados, sempre visando à previsibilidade da qualidade dos processos da empresa. As informações de entrada consideradas ${ }^{4}$ são mostradas no item 6.4 .1 e obedecem ao seguinte esquema:

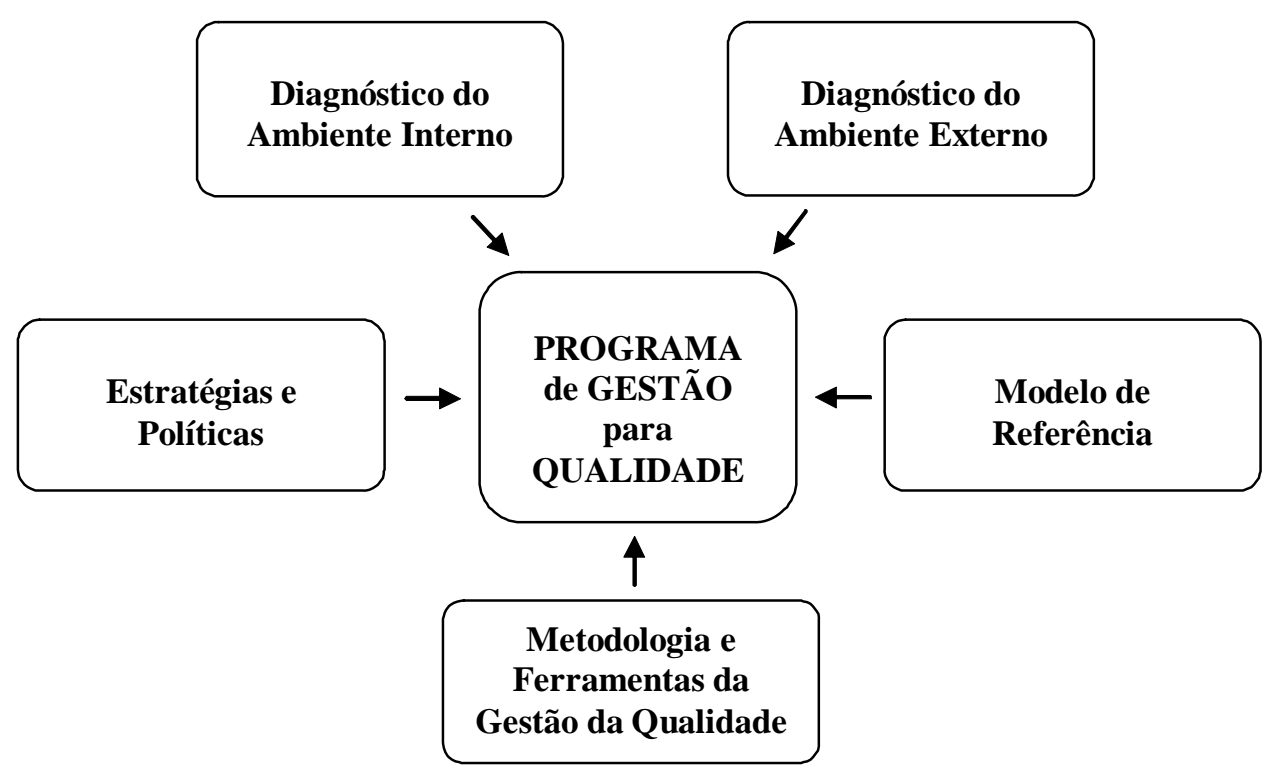

Figura 25 - Informações de entrada de um PGQT Fonte: Adaptado de Toledo e Martins (1998).

O Diagnóstico do Ambiente Externo - tem como objetivo levantar e identificar as condições atual e futura das oportunidades e ameaças oferecidas à empresa no horizonte de tempo adotado para o programa e relacionadas aos ambientes: econômico (cliente, mercado, concorrência, políticas para o setor, normas e regulamentações etc.) e tecnológico (inovações de produtos ou serviços, inovações de processos e tendências de modernização para o setor de posicionamentos com GPS). Sua realização constitui-se em pesquisas específicas no setor que mostraram os condicionantes e as tendências para o mercado de atuação da empresa (entrevistas com gerentes e/ou diretores de empresas do ramo).

\footnotetext{
${ }^{4}$ Em se tratando de uma empresa genérica (fictícia) algumas informações foram supostas.
} 
O Diagnóstico do Ambiente Interno - tem como objetivo determinar o estágio atual de preparação organizacional para implementação da gestão para a qualidade, deve considerar o mapeamento dos processos, o clima organizacional da empresa, o envolvimento da alta gerência, a motivação e o conhecimento dos funcionários, a satisfação do cliente, a melhoria contínua e a relação com os fornecedores. Sua realização baseia-se na análise de documentos da organização, além de entrevistas com a gerência/diretoria e com os funcionários e clientes (as considerações dessa etapa foram supostas por se tratar de uma empresa fictícia).

Estratégias e políticas da empresa - seu objetivo é analisar o plano estratégico e as diretrizes básicas e práticas, tais como: implantação do sistema de Gestão da Qualidade, capacitação e aumento da área de atuação no mercado, melhoria nos preços para alcançar níveis competitivos, diminuição dos custos de produção sem colocar em risco a qualidade do serviço ou as relações com fornecedores e clientes, e as modificações na estrutura da empresa antes de começar o processo de qualidade. Para sua realização deve-se considerar os questionários e entrevistas com diretores e gerentes responsáveis pela empresa (as considerações dessa etapa foram supostas por se tratar de uma empresa fictícia).

Ferramentas e metodologias da Gestão da Qualidade - definem os elementos técnicos que serão usados de acordo com as necessidades identificadas nos diagnósticos interno e externo e nas estratégias da empresa. São inúmeras as ferramentas e metodologias da qualidade que podem ser aplicadas na implementação das ações nas diferentes fases do programa, tais como:

- Engenharia da Confiabilidade;

- Círculos de Controle da Qualidade,

- Sistemas de Garantia da Qualidade, entre outros.

Considerando que a área de ação do programa é o Sistema da Qualidade, os elementos dessa etapa serão definidos posteriormente com a implantação do programa.

Modelo de referência - o objetivo do uso de um modelo de referência é nortear a elaboração do diagnóstico inicial e direcionar a implementação do Programa de Gestão da Qualidade. Neste trabalho adotou-se o modelo referencial proposto pela norma ISO série 9000:2000, e algumas considerações de outros modelos (JUSE, EFQM). 


\section{Conteúdo chave do Programa de Gestão da Qualidade}

São as informações mínimas necessárias para que o programa seja implementado na organização (no caso supôs-se que todos estariam em consonância com o modelo de referência escolhido pela organização - ISO 9000). São eles:

- pressupostos e princípios básicos;

- diretrizes e metas;

- indicadores de desempenho e marcos de avaliação;

- subprogramas;

- ações, prazos e responsabilidades;

- orientação quanto à implementação, acompanhamento e avaliação.

Os Pressupostos e princípios básicos fornecem a base filosófica do programa de Gestão da Qualidade e a orientação para a tomada de decisões e ações cotidianas na organização.

As Diretrizes e metas fornecem os caminhos básicos para a implementação do programa de Gestão da Qualidade.

Os Indicadores de desempenho e marcos de avaliação proporcionam a avaliação do andamento do programa, tanto no dia a dia quanto nos marcos de avaliação definidos (de acordo com a complexidade dos subprogramas a serem implementados), além de guiarem a ação pró-ativa rumo às diretrizes.

Os Subprogramas são conjuntos de ações que devem ser implementados para atingir uma meta específica, por exemplo: certificação do Sistema de Qualidade, melhoria da Qualidade no desenvolvimento dos produtos e serviços, controle e melhoria dos processos, qualificação e certificação dos fornecedores etc.

As Ações devem ser dispostas no tempo com prazos e responsabilidades bemdefinidos, de acordo com a seqüência lógica existente entre elas.

A Orientação quanto à implementação, acompanhamento e avaliação - o programa deve ser implementado por meio do método PDCA (Plan, Do, Check, Action), para melhorar o controle e a capacidade dos processos em toda a organização. 


\section{6 - ADAPTAÇÃO E APLICAÇÃO DO MODELO ISO 9000}

A seqüência considerada para implementação do Sistema de Gestão da Qualidade segue as recomendações da norma ISO 9001:2000, cujo princípio é da abordagem de processo, com a seguinte sistemática (Figura 26):

1. definição da unidade de negócio;

2. definição da política e dos objetivos da qualidade;

3. mapeamento dos processos;

4. padronização dos processos;

5. delineamento do Sistema de Gestão da Qualidade

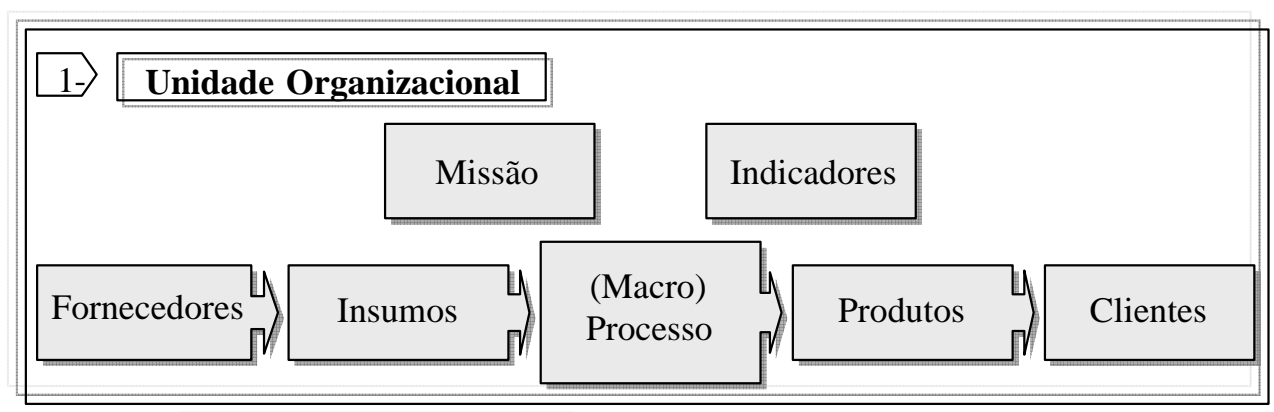

2Política da Qualidade
Objetivos da Qualidade Objetivos da Qualidade

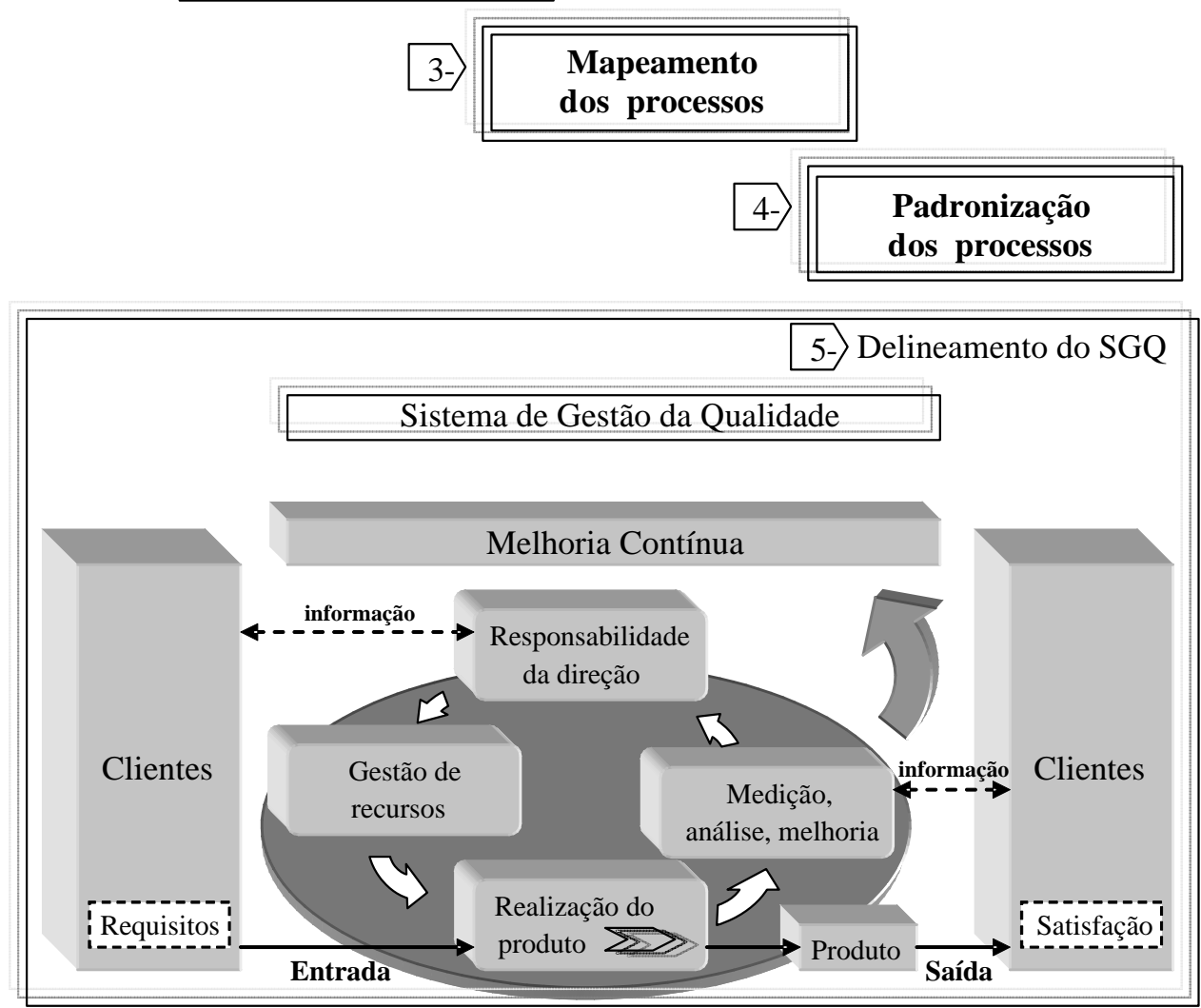

Figura 26 - Esquema de implementação do SGQ pela ISO 9000 Fonte: Adaptado de Mello et al. (2002). 


\subsection{1 - Definição da unidade de negócio}

Corresponde à unidade organizacional com definição de autoridade sobre os processos afins e responsabilidade sobre os resultados operacionais, que contribuem para a realização da missão da empresa (estrutura hierárquica, ou com relação de poder).

\subsection{2 - Definição da política e dos objetivos da Qualidade}

A política da Qualidade reflete as intenções e diretrizes globais de uma organização, leva em consideração a visão, a missão, bem como a situação estratégica em relação à concorrência e ao mercado. Os objetivos da Qualidade indicam o que se pretende atingir e devem ser consistentes com a política da Qualidade, comprometidos com a melhoria contínua e seus resultados devem ser mensuráveis.

\subsection{3 - Mapeamento de processos}

Os processos são as atividades chaves necessárias para administrar e/ou operar uma organização. Para Adair e Murray (1996) um processo é um conjunto de tarefas executadas seqüencialmente com a finalidade de gerar um resultado identificável, que pode ser um bem, um serviço, dados, ou informações. O resultado do processo é sempre direcionado a um cliente (seja ele interno ou externo) que é quem define e avalia esse resultado. Eles também afirmam que praticamente todas as organizações giram em torno de quatro processos centrais fundamentais (desenvolver o produto/serviço; gerar pedidos; atender aos pedidos e atender aos clientes) dos quais depende sua capacidade de proporcionar significativo valor ao cliente, além de sua sobrevivência e crescimento. Os demais processos (financeiros, jurídicos, de recursos humanos etc.) servem de apoio aos fundamentais.

No mapeamento dos processos considera-se a estrutura organizacional por meio de uma hierarquia, que representa o nível de detalhamento com que o trabalho é abordado, ou seja: macroprocesso; processo; atividades e tarefa ou operação.

- Macroprocesso é um processo que geralmente envolve mais que uma função na estrutura organizacional e sua operação tem impacto significativo no modo como a organização funciona.

- Processo é um conjunto de atividades seqüenciais conectadas, relacionadas e lógicas que tomam uma entrada com um fornecedor, acrescentam valor a esta e produzem uma saída (resultado) para o consumidor. 
- Atividades são ações que ocorrem dentro do processo ou subprocesso que são geralmente desempenhadas por uma unidade (pessoa ou departamento) para produzir um resultado particular (constituem a maior parte dos fluxogramas).

- Tarefa ou operação é a parte especifica do trabalho (menor microenfoque do processo), podendo ser um único elemento ou um subconjunto de uma atividade.

Para desenhar as atividades dentro de um processo, devem ser alocados os recursos apropriados, tais como representados no esquema da Figura 27.

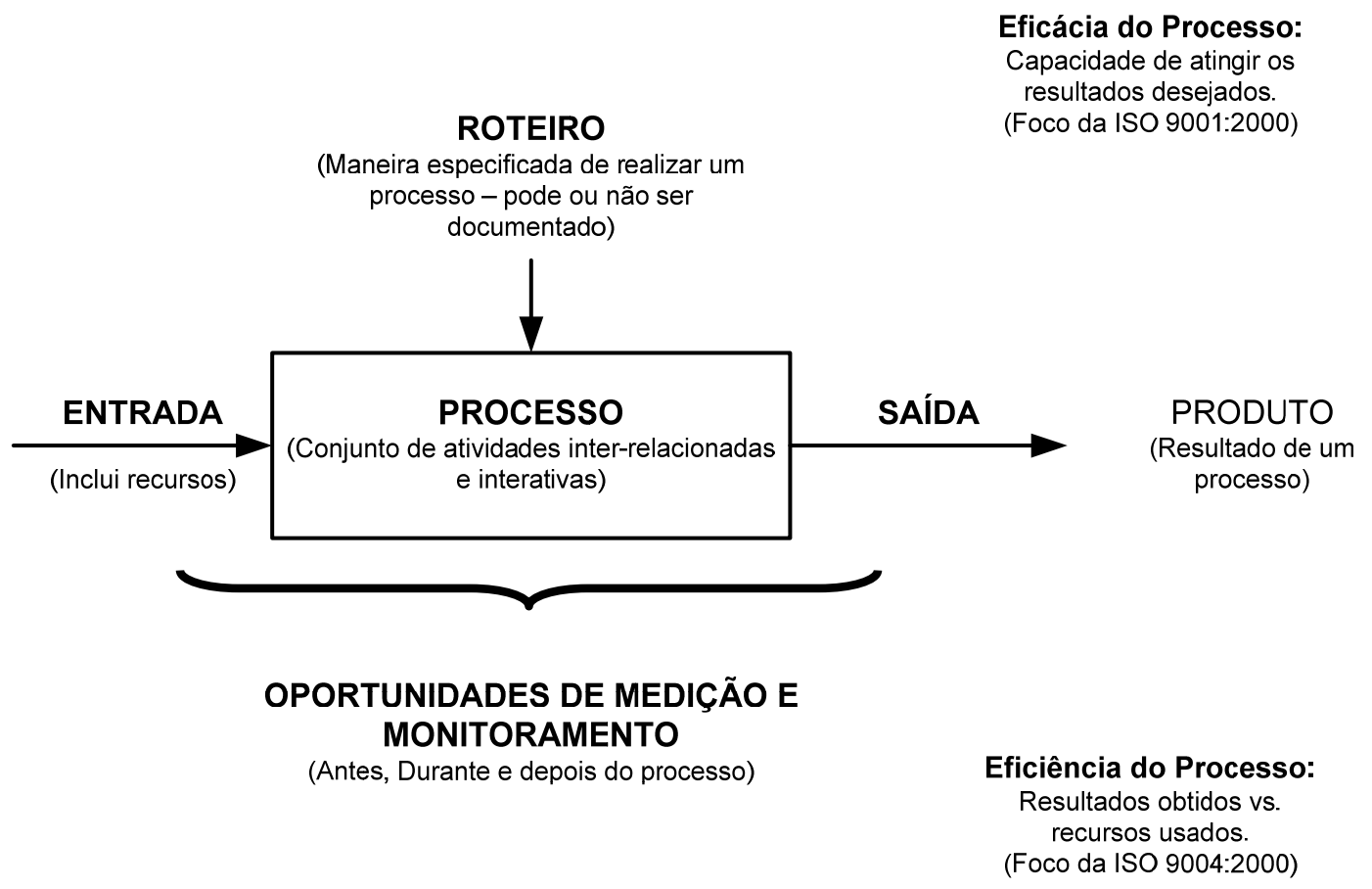

Figura 27 - Esquema de elaboração de um processo

Fonte: Adaptado de Mello et al. (2002).

A eficácia e eficiência de um processo podem ser diagnosticadas mediante processos de análises críticas internas e externas e avaliadas por meio de uma escala de maturidade. As Tabelas de maturidade (expressas em graus) vão desde "nenhuma abordagem formal" até "melhor desempenho da classe", por exemplo, o anexo A da norma NBR ISO 9004 (ABNT, 2001c).

A manutenção e a melhoria contínua da capacidade do processo podem ser atingidas pela aplicação do conceito do ciclo PDCA em todos os níveis da organização, desde os processos estratégicos de alto nível até as atividades operacionais mais simples aplicadas como parte dos processos de realização do produto. 
Um processo raramente acontece de forma isolada, em geral suas saídas formam parte das entradas do processo subseqüente, e as interações entre eles podem ser complexas, resultando em uma rede de processos interdependentes. As entradas e saídas podem ser relativas a clientes internos ou externos, conforme ilustrado na Figura 28.

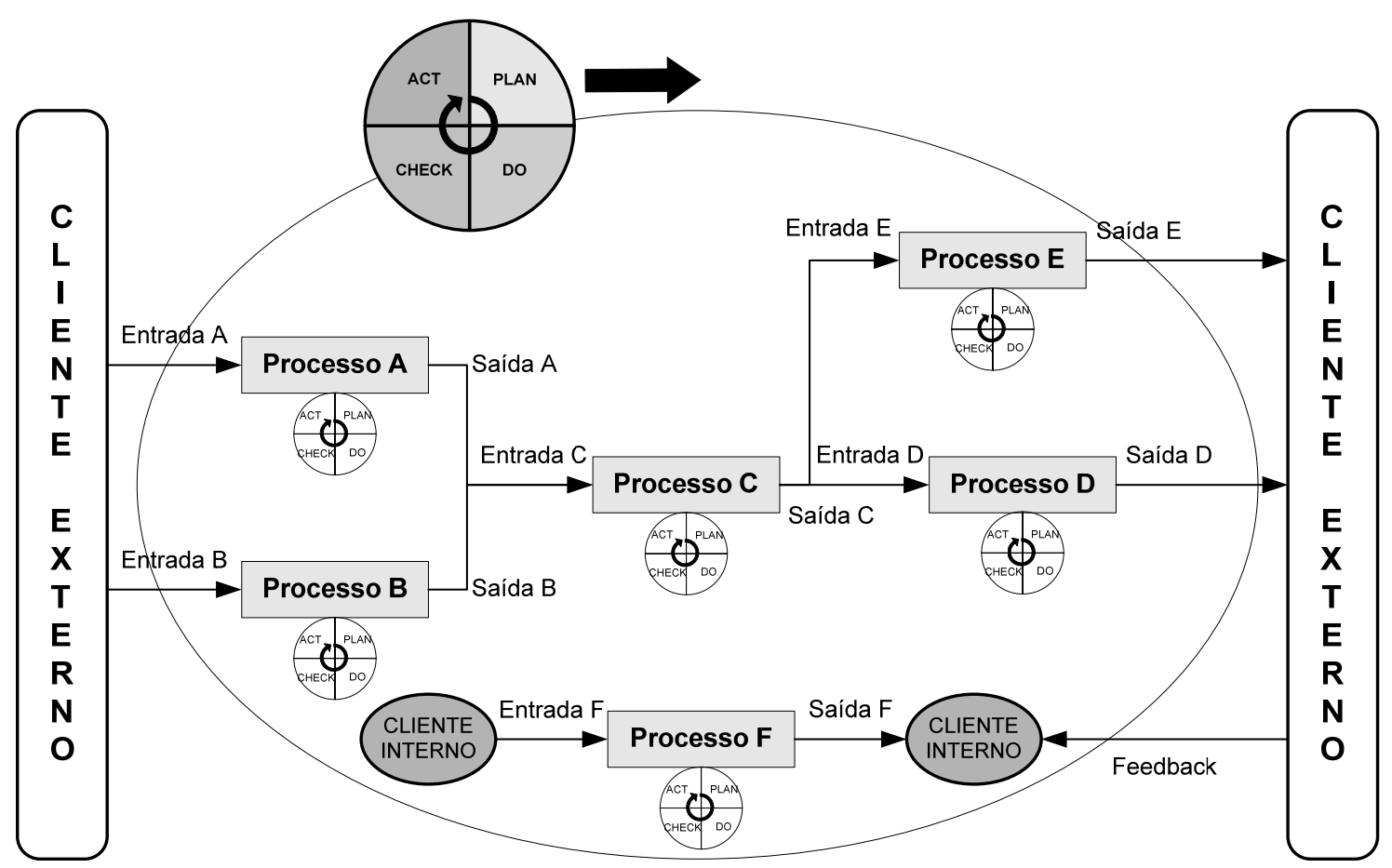

Figura 28 - Rede típica de processos interativos Fonte: Adaptado de Mello et al. (2002).

Em cada processo identificado na fase de macroprocesso, durante a definição da unidade de negócios, deve ser elaborado um fluxograma para mapear as principais tarefas ou atividades constituintes desse processo. Normalmente participam desse trabalho o comitê da qualidade, o coordenador da qualidade e os responsáveis (donos) de cada uma das unidades de negócio (engenharia, produção, compras, recursos humanos, administração, finanças, projeto, qualidade, comercial etc.) da organização.

Essa equipe deve elaborar e analisar criticamente os fluxogramas, detectando falhas e oportunidades de melhoria, destacando as tarefas críticas e eliminando as que não agregam valor ou que são duplicadas, buscando levar a organização para um patamar diferente e igual àquele que a alta direção deseja. Na elaboração dos fluxogramas, para mapeamento dos processos, alguns símbolos são usados para representar cada etapa e cada atividade, os principais são mostrados na Tabela 8. 
Tabela 8 - Simbologia usada na elaboração de fluxogramas

\begin{tabular}{|c|c|c|}
\hline n. & Símbolo & Significado \\
\hline 1 & & indica o início e o término do processo. \\
\hline 2 & & $\begin{array}{l}\text { indica cada atividade constituinte do processo que está sendo mapeado e pode } \\
\text { significar uma ação. }\end{array}$ \\
\hline 3 & & $\begin{array}{l}\text { é usado sempre que uma decisão precisar ser tomada durante o mapeamento do } \\
\text { processo, normalmente recebe uma entrada e pode ter dois ou três caminhos de saída. }\end{array}$ \\
\hline 4 & & $\begin{array}{l}\text { indica um documento ou registro gerado ou usado para implementar a atividade a qual } \\
\text { está conectado. Seu sentido é em direção à atividade (contrário ao fluxo). }\end{array}$ \\
\hline 5 & & $\begin{array}{l}\text { chamado de conector, serve para mostrar a continuidade de uma parte do fluxo em } \\
\text { outro ponto ou em outra página. }\end{array}$ \\
\hline 6 & & $\begin{array}{l}\text { indica o arquivamento de um documento ou registro, ou o armazenamento de um } \\
\text { produto no decorrer do fluxograma. }\end{array}$ \\
\hline 7 & & indica o sentido do fluxo do processo. \\
\hline
\end{tabular}

\subsection{4 - Padronização de processos}

Os objetivos básicos buscados com a padronização dos processos são dois:

- obter resultados previsíveis em processos repetitivos, garantindo, assim, a qualidade previsível aos clientes,

- proporcionar e manter o domínio tecnológico nas organizações.

Uma organização é detentora do domínio tecnológico sobre seus processos, quando possui um sistema estabelecido e a garantia de que o que está sendo executado pelas pessoas corresponde ao que está documentado pelo sistema. A padronização garante a manutenção do domínio tecnológico da empresa, tirando-o das cabeças das pessoas e trazendo-o para o conhecimento de todos.

A padronização dos processos é complementar ao mapeamento dos processos, pois, fornece os detalhes a respeito da operacionalização de cada atividade, definindo quem, quando, o quê, onde, por que e como. A padronização não se limita ao estabelecimento do padrão, mas inclui também sua utilização, pois de nada adianta redigir um procedimento ou uma instrução operacional e deixá-la guardada dentro de uma gaveta. Os colaboradores ou usuários devem ser treinados nesse padrão para que o utilizem no seu dia a dia.

A padronização é implementada por meio de dois tipos de padrões: os padrões de sistema e os padrões técnicos. 
- os padrões de sistema são documentos estabelecidos para assuntos relativos à organização e suas interfaces como organograma, procedimentos de controle de projeto, procedimento de treinamento e procedimento de aquisição.

- os padrões técnicos são estabelecidos para assuntos técnicos relacionados direta ou indiretamente a um produto ou processo, como especificações de matéria prima e de produto, plano de inspeção de recebimento e instruções operacionais.

A padronização inicia-se pela escolha de uma atividade ou processo mapeado mediante fluxograma, em que se elabora um procedimento geral para descrever as interfaces (quem, quando, o quê, onde, por que e como) e baseado no mesmo fluxograma selecionam-se as atividades críticas que necessitam ser padronizadas por meio de instruções operacionais (Figura 29).

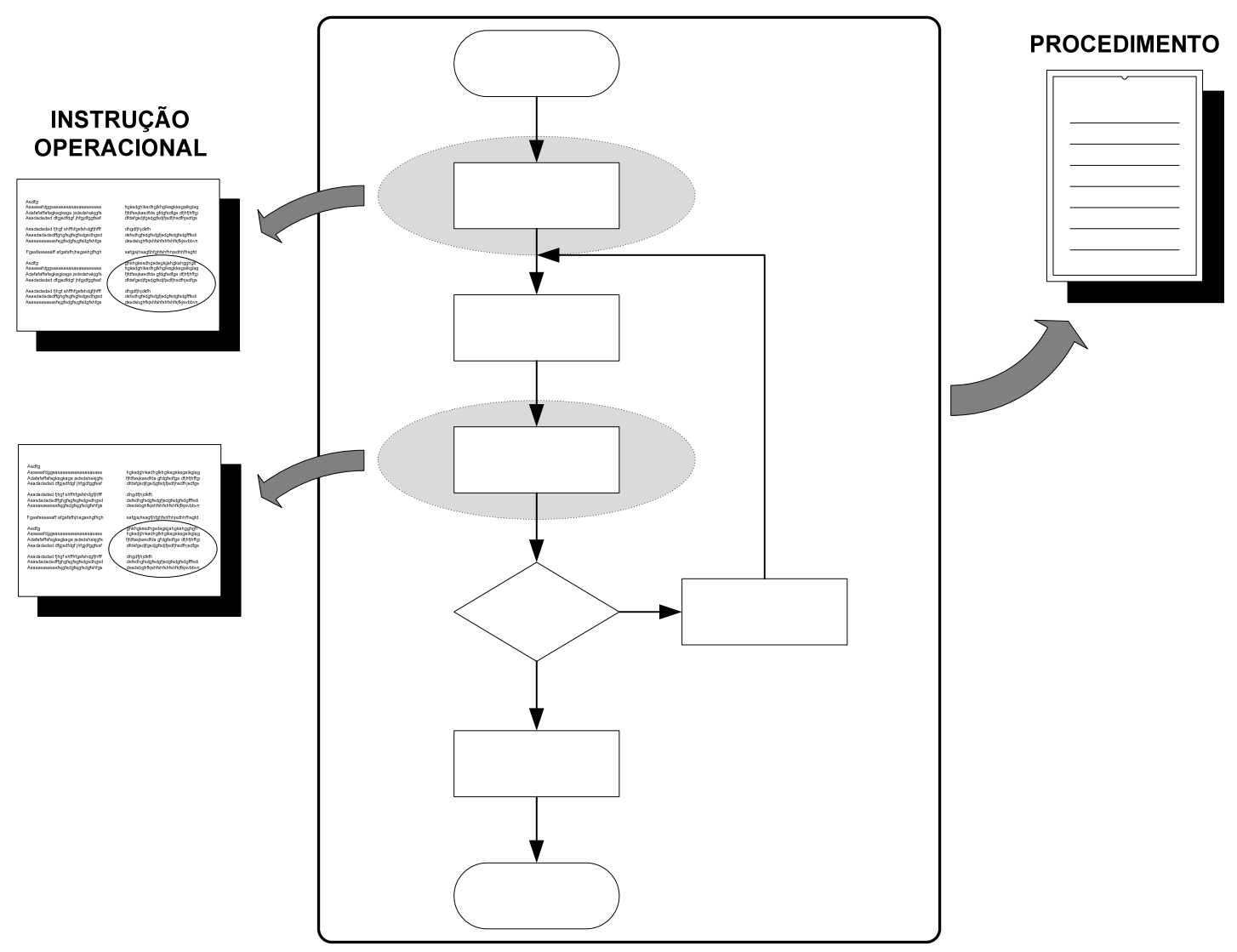

Figura 29 - Padronização de processos Fonte: Adaptado de Mello et al. (2002).

Esses documentos precisam ser padronizados em linguagem que os usuários entendam, (regional, jargões da área, e até gírias) e antes de aprovados e oficializados devem ter o consenso de todas as pessoas e áreas envolvidas com a sua utilização. 


\subsection{5 - Delineamento do Sistema de Gestão da Qualidade}

Depois de mapeados e padronizados os processos do dia a dia da empresa, começa-se então a descrever e padronizar os processos exigidos pela norma ISO 9001:2000 (com vistas a certificação) e que dão sustentação ao sistema de Gestão da Qualidade.

A metodologia a ser seguida é a mesma usada para os processos de produção/ prestação de serviço e apoio existentes na organização, ou seja, inicia-se pelo mapeamento de processos e, em seguida, padroniza-se o mesmo mediante procedimentos e instruções operacionais. Muitos dos processos a serem mapeados nascerão nesse momento, pois muitas empresas não os praticam em seu dia-a-dia. A Tabela 9 mostra os processos que devem ser padronizados na etapa de padronização e na etapa de delineamento do Sistema da Qualidade.

Tabela 9 - Processos das etapas de padronização e delineamento do SQ.

\begin{tabular}{|c|c|}
\hline Etap & Etapa de Delineamento \\
\hline $\begin{array}{l}\text { - Controle de documentos } \\
\text { - Projeto e desenvolvimento de produtos } \\
\text { - Controle de processos produtivos } \\
\text { - Aquisição (compras) } \\
\text { - Planejamento da produção (PCP) } \\
\text { - Vendas e serviços associados (pós-vendas) } \\
\text { - Instalação de obras } \\
\text { - Admissão e demissão de funcionários } \\
\text { - Contas a pagar e a receber } \\
\text { - Treinamento } \\
\text { - Custos industriais } \\
\text { - Recebimento de materiais } \\
\text { - Inspeção de produtos } \\
\text { - Definição do organograma organizacional } \\
\text { - Identificação dos produtos }\end{array}$ & $\begin{array}{l}\text { - Controle de registros } \\
\text { - Elaboração do Manual da Qualidade } \\
\text { - Definição de autoridades e responsabilidades (descrição } \\
\text { de cargos) } \\
\text { - Análise critica do Sistema da Qualidade pela alta } \\
\text { direção } \\
\text { - Planejamento da qualidade } \\
\text { - Controle de dispositivos de medição e monitoramento } \\
\text { - Rastreabilidade de produtos } \\
\text { - Propriedade do cliente } \\
\text { - Preservação do produto } \\
\text { - Análise de dados e técnicas estatísticas } \\
\text { - Auditoria interna da qualidade } \\
\text { - Medição da satisfação de clientes } \\
\text { - Controle de produção não conforme } \\
\text { - Ação corretiva e ação preventiva } \\
\text { - Melhoria contínua }\end{array}$ \\
\hline
\end{tabular}

À medida que os processos forem sendo padronizados, devem ser implementados por meio de treinamento dos colaboradores (aplicados aos documentos correspondentes aos processos em que estão envolvidos). Depois de implementados, devem ser programadas pequenas auditorias internas para avaliar o trabalho, corrigindo eventuais falhas e buscando melhorias. Os principais elementos considerados na aplicação e adaptação do modelo ISO 9000 à empresa genérica são apresentados no Capítulo 6 junto com o programa proposto. 


\section{6 - O PROGRAMA DE GESTÃO DA QUALIDADE PROPOSTO}

Neste capitulo é apresentado o programa (modelo) para a implantação da Gestão da Qualidade em uma empresa genérica de posicionamento com GPS. O modelo foi desenvolvido com vistas à implantação e à melhoria da Gestão da Qualidade aplicada especificamente à empresa de GPS. Sua elaboração partiu da análise dos resultados de uma pesquisa social (referente à Gestão da Qualidade em empresas do ramo), e fundamentou-se no referencial teórico consultado, além das orientações de profissionais da área da qualidade. O modelo proposto destina-se a uma organização com características similares á empresa genérica (fictícia) considerada. Assim sendo, deverá ser testado de forma prática para verificação das dificuldades na implantação e utilização nas empresas.

\section{1 - O MODELO}

O modelo apresenta uma seqüência de etapas cujo objetivo é fornecer um caminho lógico para implementação da Gestão da Qualidade. As etapas foram definidas considerando a situação mais desfavorável (pobre) de Gestão da Qualidade na empresa e cujo propósito evolutivo foi caracterizado pelos seguintes elementos principais apresentados esquematicamente na Figura 30.

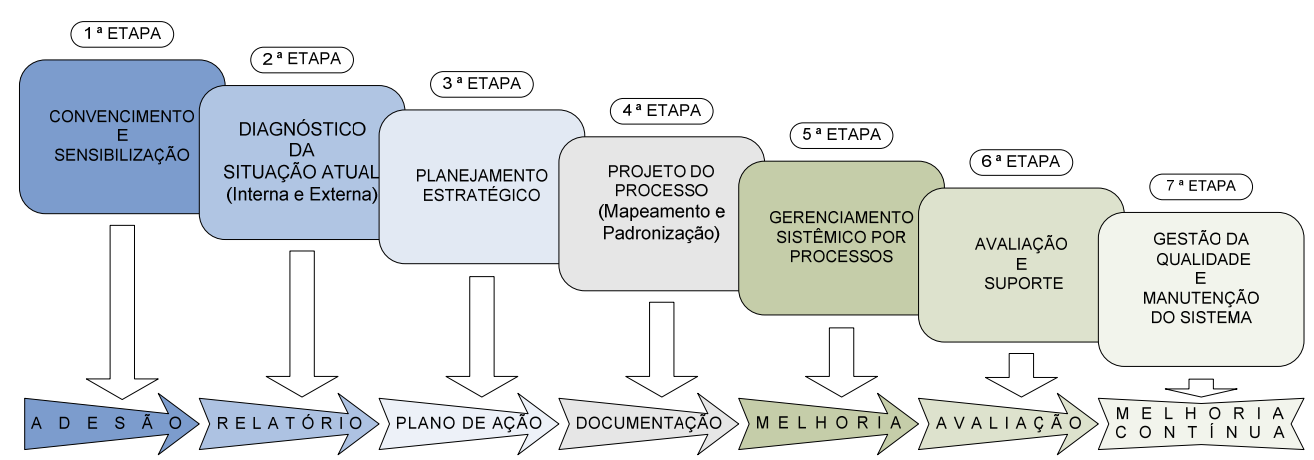

Figura 30 - Esquema do Modelo de Gestão da Qualidade proposto 
Para cada etapa do modelo são apresentados de forma resumida (Figuras 31 e 32) os procedimentos de ação correspondente, os resultados prováveis a serem alcançados, além de uma estimativa de tempo para realização.

\begin{tabular}{|c|c|c|}
\hline $1{ }^{\text {a }}$ ETAPA & PROCEDIMENTOS & RESULTADOS ESPERADOS \\
\hline $\begin{array}{c}\text { CONVENCIMENTO } \\
\text { E } \\
\text { SENSIBILIZAÇÃO }\end{array}$ & $\begin{array}{ll}\bullet & \text { APRESENTAÇÕES } \\
- & \text { DIVULGAÇÃO } \\
- & \text { REUNIÕES } \\
\text { - } & \text { CURSOS RÁPIDOS } \\
\text { - } & \text { INCENTIVOS } \\
- & \text { Definir ESTRUTURA MÍNIMA }\end{array}$ & \begin{aligned} & \multicolumn{1}{l}{$($ ADESÃO) } \\
& - PARTICIPAÇÃO \\
& - ATITUDE \\
& - COMPROMETIMENTO \\
& - SUGESTÕES \end{aligned} \\
\hline Tempo: $\approx 1$ (mês) & & EINV ULVIIVIEINIU \\
\hline
\end{tabular}
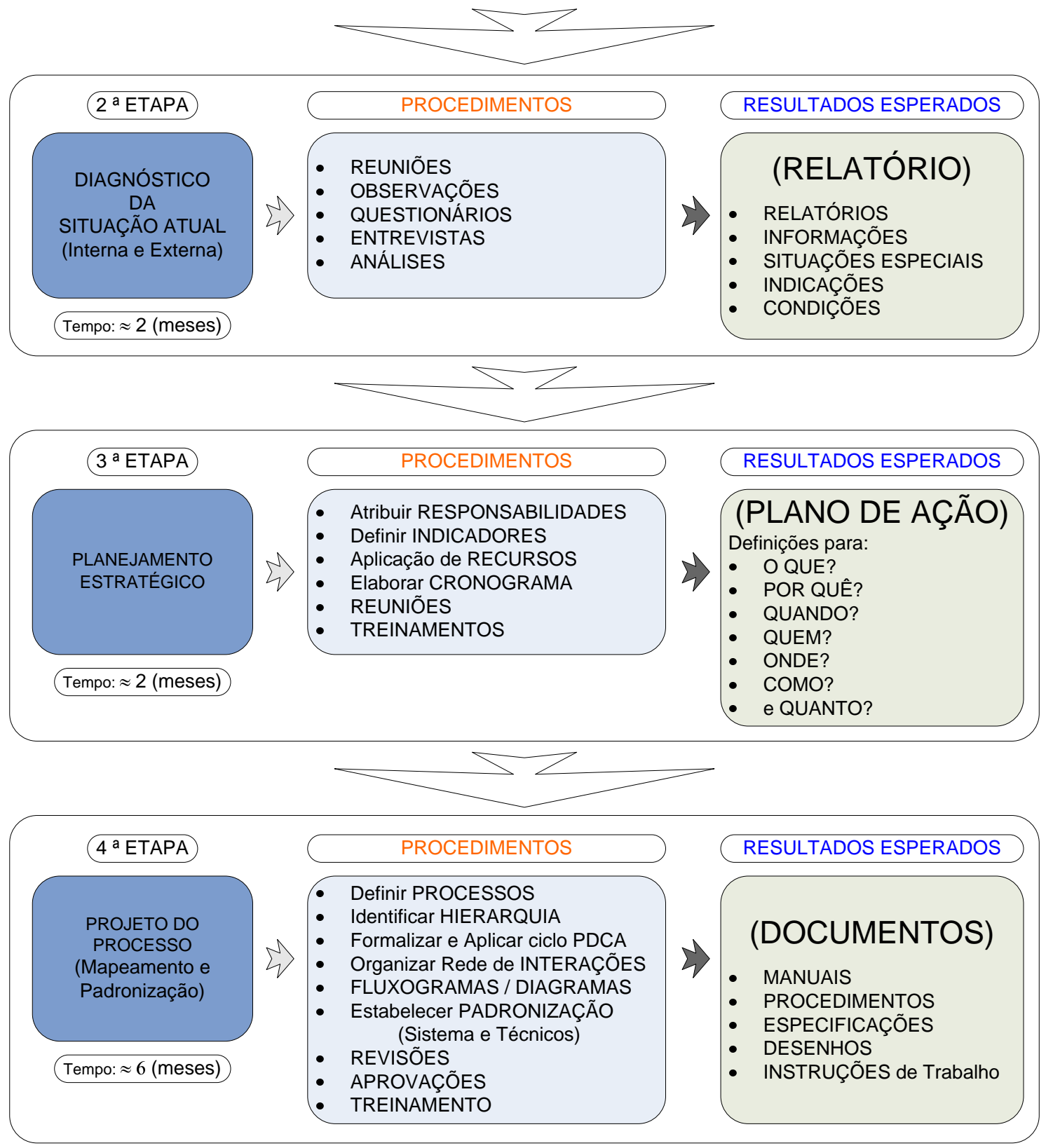

Figura 31 - Sumário das etapas de 1 a 4 do Modelo de GQ proposto 


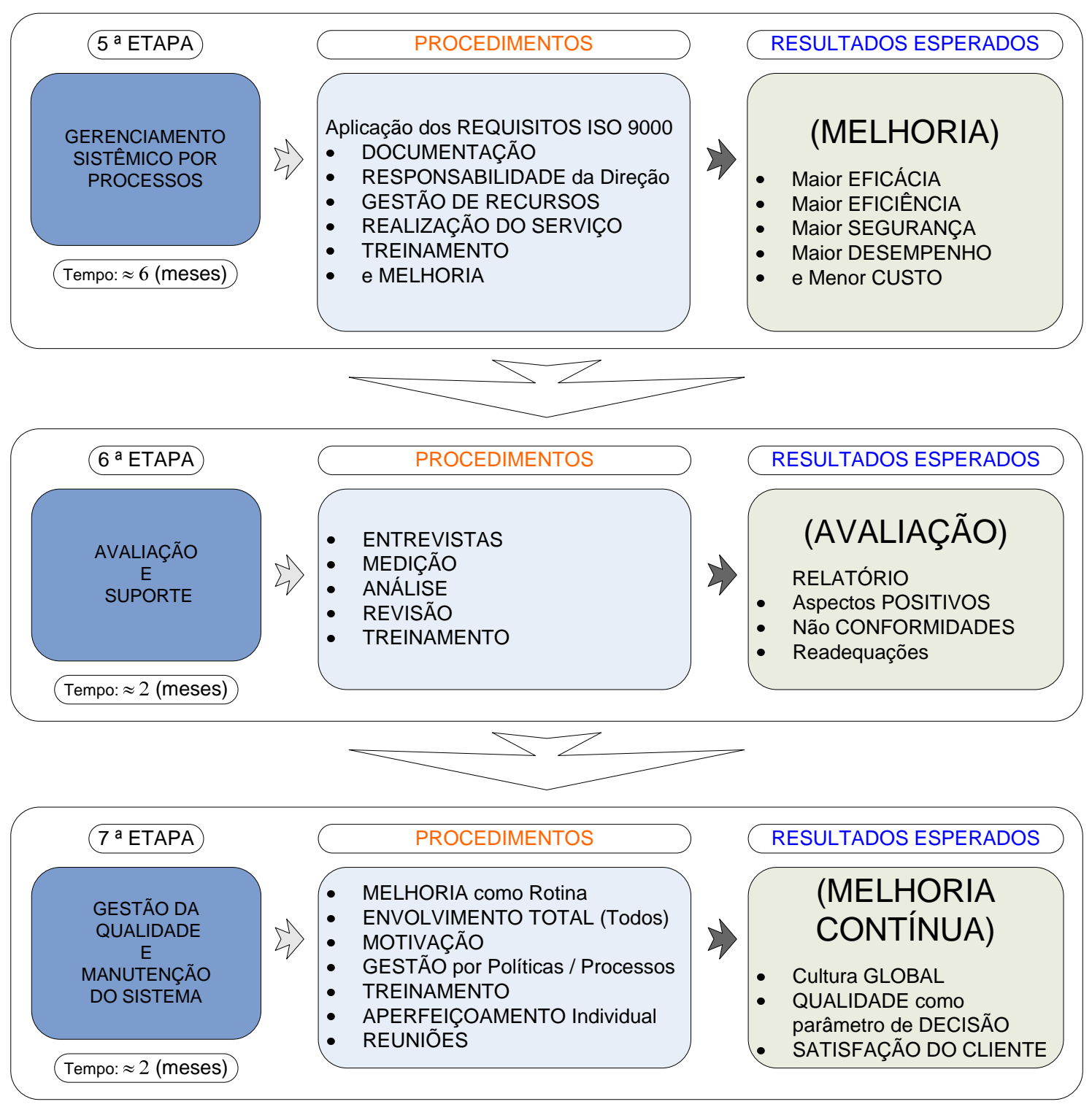

Figura 32 - Sumário das etapas de 5 a 7 do Modelo de GQ proposto

\section{2 - ETAPAS DE IMPLANTAÇÃO}

Na implantação de um Sistema de Gestão da Qualidade é fundamental que a alta administração esteja 100\% comprometida com a qualidade. No caso de uma empresa de posicionamento com GPS, esse apoio provém do dono (presidente ou diretor executivo), sem o qual será impossível obter sucesso na implantação do programa. Portanto só se deve iniciar o processo de implantação se a direção (quem detém o poder de decisão) estiver e se mostrar plenamente convencida e envolvida no processo. Afinal de contas, exemplos e atitudes demonstrados pelo líder normalmente influenciam todos na equipe. 
Com base nas informações anteriores, o modelo proposto pode ser aplicado tanto para empresas novas, como para empresas já existentes, desde que consideradas as observações citadas para cada caso.

\subsection{1 - Convencimento e Sensibilização}

Essa etapa tem como objetivo principal conseguir apoio e compromisso de todos os membros da empresa (todos os níveis) para o desenvolvimento das atividades ligadas à Qualidade. Entre os instrumentos e procedimentos para desenvolver essa etapa têm-se:

- reuniões de trabalho para apresentação, divulgação e discussão das propostas;

- seminários técnicos;

- cursos rápidos para motivação;

- recursos de multimídia (faixas, cartazes, vídeos, chamadas p/ e-mail e intranet);

- incentivos (distribuição de prêmios),

- atividade social (café, coquetel, churrasco, confraternização).

A motivação para a Qualidade compreende o crescimento das pessoas na empresa rumo ao perfil desejado e deve, portanto, promover junto de todos os elementos a motivação para a Qualidade, além de identificar as necessidades que devem ser satisfeitas para cada nível de maturidade.

Atualmente, as empresas que não investem em clientes internos acabam perdendo a qualidade dos serviços prestados ao cliente externo. Certamente treinar a Alta Administração na motivação para a Qualidade será o primeiro passo para provocar as verdadeiras mudanças e o sucesso da empresa. A Alta Administração desempenha papel fundamental para que a empresa conquiste com seus clientes internos a motivação para a Qualidade, pois ela, junto com os diretores e coordenadores, é a grande responsável pelo processo de amadurecimento de seus subordinados.

O resultado esperado com o desenvolvimento dessa etapa é a máxima adesão das pessoas da empresa, proporcionada por meio de uma participação efetiva que resulte em mais atitudes, motivação, comprometimento, eliminação de barreiras, pois é preciso que todos, sem exceção, estejam plenamente convencidos de que a Qualidade é fundamental e se sintam engajados com sua implementação na organização. A $1^{\text {a }}$ Etapa da Figura 31 representa esquematicamente o processo. 


\subsection{2 - Diagnóstico da Situação Atual}

A identificação das características do ambiente (interno / externo) é imprescindível para adotar uma postura mais adequada no momento de expor a nova filosofia de trabalho. A cultura do ambiente tem uma força muito grande e por isso precisa ser considerada. Os valores e crenças das pessoas no ambiente em que se pretende trabalhar a Gestão da Qualidade têm importância significativa para se conseguir apoio e comprometimento, pois, conhecendo o ambiente, é mais fácil identificar as atitudes bem vindas e as que certamente devem ser rejeitadas.

Praticamente todas as organizações possuem alguma parte de um Sistema de Gestão da Qualidade, seja ele formal ou informal, desconexo, conflitante ou normalmente sem registros mínimos, porém, sem os quais simplesmente não funcionariam. Conhecer os documentos, métodos e principalmente a cultura da empresa são fundamentais, pois se ganhará um precioso tempo aproveitando-o na elaboração da documentação do SGQ. Contudo, deve-se valer somente do que de bom já existir e não se deixar influenciar pelos vícios existentes que fatalmente devem ser rejeitados.

O objetivo principal dessa etapa é identificar as principais características do ambiente (interno / externo), onde se pretende implantar a Gestão da Qualidade nos serviços de posicionamento com GPS, para usá-las como suporte no delineamento das estratégias e na condução das atividades de implantação. Entre os instrumentos e procedimentos para desenvolver essa etapa tem-se:

- reuniões de trabalho;

- $\quad$ pesquisas de opiniões;

- entrevistas /questionários,

- observações do local.

O resultado esperado com o desenvolvimento dessa etapa é um relatório de diagnóstico contendo as principais características do ambiente e de seus membros, com indicação das ações atualmente aplicadas que serão aceitas e as que serão rejeitadas, além de um relato sucinto sobre as experiências dos membros da empresa com relação à Gestão da Qualidade. A 2a Etapa da Figura 31 representa esquematicamente o processo. 


\subsection{3 - Planejamento Estratégico}

Esta etapa tem como objetivo principal elaborar o plano de ação para implantação do SGQ, com base nas informações obtidas na etapa de diagnóstico da situação atual. O plano deve conter informações claras, entre outras, sobre todas as ações que serão desenvolvidas, as seqüências de realizações, quais serão os responsáveis, quais os prazos (cronograma) e os recursos que serão destinados, ou seja, a definição de "o que fazer” e principalmente de “como fazer”.

Pelas características próprias do ambiente do setor de GPS, convém que as decisões, sempre que possível, sejam tomadas em conjunto com toda a equipe e necessariamente com o apoio da Coordenação. É importante também definir um conjunto de indicadores para que se possa fazer a mensuração dos resultados obtidos com a implantação do Sistema da Qualidade. Cada setor deverá definir o conjunto de indicadores adequado à sua realidade, podendo se basear, por exemplo, nos indicadores do PQGF (Prêmio da Qualidade do Governo Federal), ou nos indicadores do PNQ (Prêmio Nacional da Qualidade). Entre os instrumentos e procedimentos para desenvolver essa etapa têm-se:

- reuniões de trabalho;

- pesquisas bibliográficas;

- definições de indicadores;

- atribuição de responsabilidades,

- elaboração de cronograma (físico e financeiro).

O resultado esperado com o desenvolvimento dessa etapa é um documento cujo conteúdo mostre claramente a seqüência de ações, as responsabilidades, os custos envolvidos, os prazos e as estratégias a serem adotadas. O plano de ação deve, portanto, definir a visão, os rumos, o caráter, os objetivos, as metas e os investimentos da empresa, ou seja, o que, porque, quando, quem, onde, como e quanto. Em outras palavras, o processo resultante dessa etapa deve ser eficiente, eficaz e fornecer suporte necessário para a empresa tomar suas decisões. A agilidade freqüente e contínua da empresa, em sintonia com as variáveis do seu ambiente, será a melhor forma de se minimizar a probabilidade de que as mudanças se constituam em surpresa. Dessa forma, a flexibilidade do processo permitirá obter benefícios das oportunidades existentes ou futuras, como também prevenir ameaças reais ou potenciais. A $3^{\text {a }}$ Etapa da Figura 31 representa esquematicamente o processo. 


\subsection{4 - Projeto do Processo}

Esta etapa consiste na elaboração dos documentos necessários para apoiar a implantação do sistema de Gestão da Qualidade. Com o mapeamento e a padronização dos processos o trabalho de implantação do SGQ é sensivelmente simplificado, facilitando a elaboração de documentos específicos como o Manual da Qualidade (MQ), que é o documento chave que define as linhas mestras do sistema.

Para o desenvolvimento de todas as atividades, deve ser considerada a participação de todos os membros das equipes/setores nas quais se pretende aplicar a Gestão da Qualidade. Entre os instrumentos e procedimentos para desenvolver essa etapa têm-se:

- reuniões de trabalho;

- entrevistas;

- questionários;

- definição e mapeamento de processos;

- formalizar e aplicar ciclo PDCA;

- padronização de processos;

- revisão e aprovação de documentos,

- treinamentos.

O resultado esperado com o desenvolvimento dessa etapa é obter um conjunto de documentos contendo manuais, procedimentos, especificações, desenhos e instruções de serviços que foram elaborados, revisados e aprovados de acordo com a política da qualidade da empresa. Uma seqüência para a elaboração dos principais documentos indicados pela norma ISO 9000 é apresentada a seguir.

\section{Procedimentos:}

Documento de caráter técnico administrativo, que serve para orientar e facilitar o entendimento quanto às diretrizes que normalizam os sistemas e/ou atividades da empresa, retratando seus diversos objetivos e responsabilidades. Um documento, antes de ser liberado, deve passar pelas etapas de: elaboração, verificação, aprovação, autorização, formatação, inclusão no sistema, implementação, revisão, cancelamento. A geração e a implementação, seja a primeira ou em suas sucessivas revisões, devem sempre respeitar de maneira rigorosa a cadeia de geração. 
Para se escrever os procedimentos apresenta-se um modelo básico que pode ser utilizado para ambientes de serviços em GPS, conforme Figura 33.

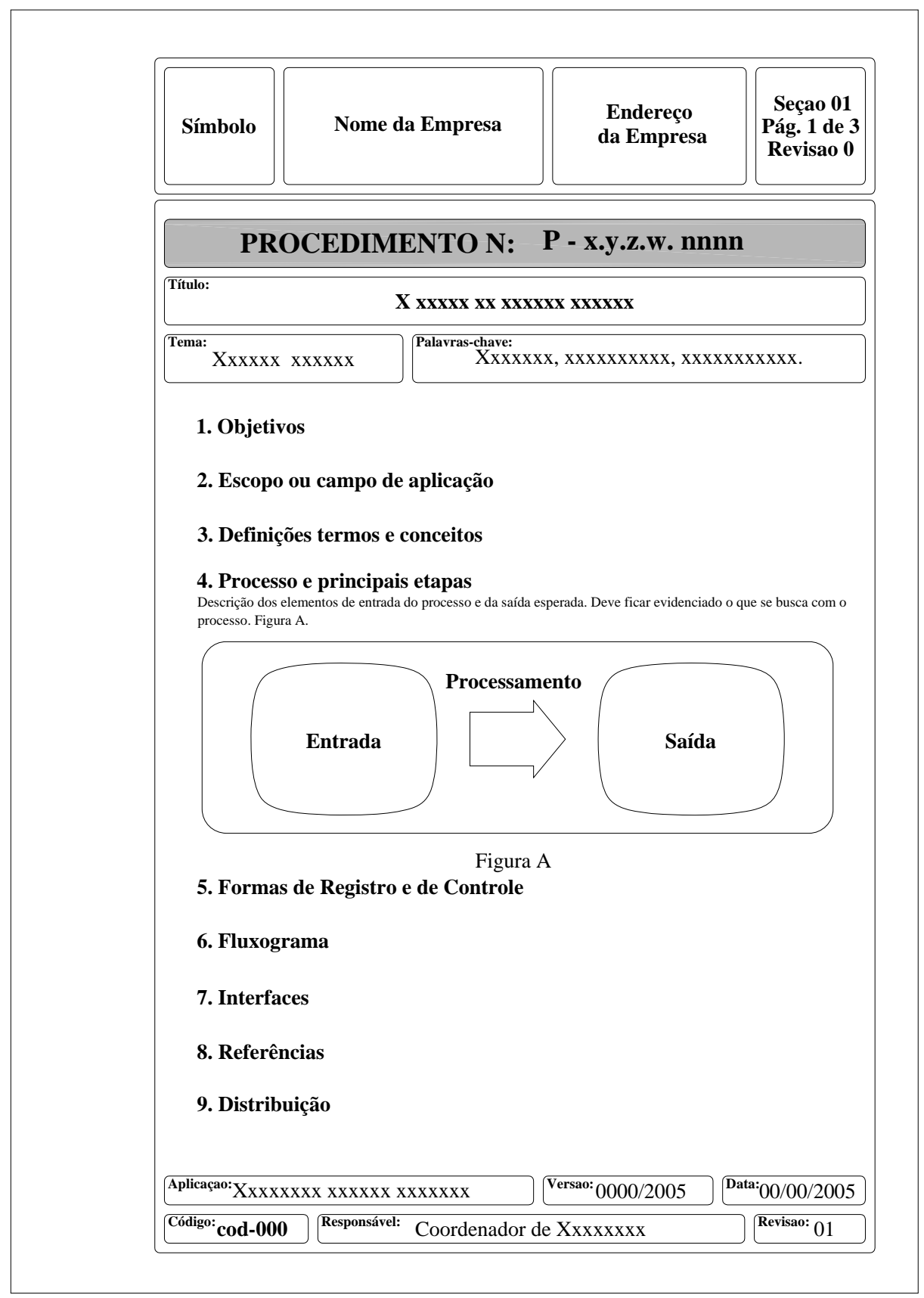

Figura 33 - Modelo básico para procedimentos (Documentação)

\section{Instruções de trabalho}

São documentos de menor abrangência que os procedimentos e se destinam a descrever a maneira correta de executar uma operação e/ou tarefa, de modo simples e direto. Como sugestão de modelo básico para ser utilizado em ambiente de GPS, tem-se um documento similar ao padrão básico para procedimentos (Figura 33), porém contendo apenas: objetivo, escopo e principais atividades. 


\section{Manual de Projetos:}

É importante criar formulários específicos para cada etapa de um projeto, procurando identificar quais os dados que seriam relevantes para o acompanhamento em todas as suas fases. Um projeto tem etapas básicas que são: começo, meio e fim previstos e programados. Isso permite desde o início possuir uma visão do ciclo de vida do projeto. O ciclo de vida de um projeto com GPS é composto basicamente pelas etapas mostradas no item 3.5.

Como sugestão para a formatação do modelo de formulário para as partes que compõem o manual de projetos, apresenta-se o esquema da Figura 34 que contém de uma forma básica a distribuição das informações.

\begin{tabular}{|c|c|c|c|c|}
\hline Cabeçalho & Símbolo & Nome da Empresa & $\begin{array}{c}\text { Endereço } \\
\text { da Empresa }\end{array}$ & $\begin{array}{l}\text { Seçao: } \\
\text { Pág. de } \\
\text { Revisao: }\end{array}$ \\
\hline $\begin{array}{l}\text { Corpo do } \\
\text { formulário }\end{array}$ & \multicolumn{4}{|c|}{$\begin{array}{l}\text { Título e número do formulário } \\
\text { Tema e autor } \\
\text { Objetivo } \\
\text { Justificativa } \\
\text { Metodologia } \\
\text { Equipe e infra-estrutura necessária } \\
\text { Orçamento hora/custo } \\
\text { Obrigações do contratado e do contratante } \\
\text { Cronograma físico/financeiro } \\
\text { Responsáveis pelas partes } \\
\ldots\end{array}$} \\
\hline \multirow{2}{*}{ Rodapé } & Contrato: & & \multicolumn{2}{|c|}{ Data: } \\
\hline & Código: & Responsável: & & Revisao: \\
\hline
\end{tabular}

Figura 34 - Sumário das etapas de 5 a 7 do Modelo de GQ proposto

\section{Manual da Qualidade}

O Manual é o documento geral da Gestão da Qualidade. O passo inicial para sua elaboração é a seleção da Norma, que, para no caso específico desta tese, é a ISO 9001:2000. Da norma devem-se tirar explicações complementares e importantes alertas quanto aos requisitos. As Normas ISO 9000 possuem itens mandatários e nãomandatários. É essencial que o Manual contenha todos os itens mandatários, podendo conter ou não os itens não-mandatários. É importante que o Manual da Qualidade faça referência aos outros documentos da qualidade tais como: Procedimentos, Instruções de Trabalho e Manual de Projetos. A $4^{\mathrm{a}}$ Etapa da Figura 31 representa esquematicamente o processo. 


\subsection{5 - Gerenciamento Sistêmico por Processos}

Esta etapa objetiva aplicar de forma sistêmica as diretrizes gerais para se conduzir e operar uma empresa de posicionamento com GPS, na implementação de um sistema de Gestão da Qualidade com base no padrão adotado. No caso especifico deste trabalho foram adotados os requisitos da norma ISO 9001:2000. Entre os instrumentos e procedimentos para desenvolver essa etapa têm-se:

- documentação de procedimentos;

- definição de responsabilidades da direção (política, avaliação e melhorias);

- provisão de recursos financeiros, humanos e prediais;

- realização do serviço (abordagem por processos);

- treinamento;

- melhoria.

O resultado esperado com o desenvolvimento dessa etapa é a melhoria na qualidade dos serviços da empresa, através do aumento dos fatores de eficiência e eficácia, desempenho, segurança e, conseqüentemente, redução de custos e aumento do lucro. Nesta etapa podem ser usadas ferramentas de apoio consagradas em conjunto com o gerenciamento sistêmico, tais como o ciclo PDCA, a aplicação dos 5S's e a estratégia 6 sigma (não tratados nesta tese). A $5^{\text {a }}$ Etapa da Figura 32 representa esquematicamente o processo.

\subsection{6 - Avaliação e suporte}

Nessa etapa são feitas avaliações para diagnosticar o estado de envolvimento e a aplicação da filosofia da Qualidade em serviços por todos os membros da empresa de posicionamento com GPS. Nesta etapa de avaliação será possível detectar erros e deficiências na aplicação de todos os procedimentos e verificar se está sendo cumprido o Manual da Qualidade. Os pontos vulneráveis (não conformes) devem ser identificados e corrigidos/eliminados com apoio e treinamento (suporte) para uma readequação e melhoria contínua do sistema. Entre os instrumentos e procedimentos para desenvolver essa etapa têm-se:

- entrevistas;

- análise de documentos (critérios da ISO 9000);

- reuniões de trabalho; 
- utilização de indicadores;

- revisões de não conformidades;

- treinamentos.

O resultado esperado com o desenvolvimento dessa etapa é um relatório contendo os aspectos positivos, as evidências objetivas de melhorias, as mudanças necessárias implementadas e as não-conformidades eliminadas. A 6 ${ }^{\text {a }}$ Etapa da Figura 32 representa esquematicamente o processo.

\subsection{7 - Gestão da Qualidade e Manutenção do Sistema}

O objetivo principal dessa etapa é a confirmação definitiva e manutenção da implementação do sistema de Gestão da Qualidade na empresa de posicionamento com GPS. A comprovação pode ser feita pela percepção “in-loco” do envolvimento e da motivação de todas as pessoas da empresa, bem como pela análise dos documentos, a partir da lista de itens normativos (ISO 9000). Para a manutenção, as ações consistem em treinamento e reciclagem em relação à qualidade, com a busca contínua das oportunidades de melhoria.

É fundamental nessa etapa ter um responsável crítico e bastante atuante, que cobre e chame atenção sobre a manutenção das atividades e a utilização dos formulários pertinentes à qualidade. Embora a rotatividade não seja grande no ambientes de GPS, as ações de manutenção deverão ser constantes sempre buscando a integração de todos os membros com a filosofia da Gestão da Qualidade da empresa. Entre os instrumentos e procedimentos para desenvolver essa etapa incluem-se:

- reuniões;

- entrevistas;

- fichas de avaliação;

- envolvimento total das pessoas;

- motivação;

- melhoria contínua como rotina;

- gestão por políticas e processos;

- treinamento,

- aperfeiçoamento individual. 
O resultado esperado nessa etapa é a melhoria contínua confirmada pela implantação e manutenção do SGQ na empresa de posicionamento com GPS, expressados por meio da cultura global para a qualidade, do enfoque empresarial que trata a qualidade como parâmetro de decisão e, por fim, da satisfação do cliente que é o mais importante. A $7^{\text {a }}$ Etapa da Figura 32 representa esquematicamente o processo.

\section{3 - VIABILIDADE E RECOMENDAÇÕES DE APLICAÇÃO}

O modelo proposto é adequado para uma empresa, nova ou implantada, com características semelhantes às da empresa genérica (fictícia) GPSAT considerada nesse trabalho. Sua adequação ocorrerá a partir do instante em que as etapas forem sendo executadas.

Alguns elementos do modelo podem sofrer alterações em função das informações coletadas na etapa de diagnóstico inicial. Isto é: para uma empresa (organização) de posicionamento com GPS, embora as etapas de implantação de um Sistema de Gestão da Qualidade possam ser semelhantes às de uma outra empresa, a estratégia adotada deve ser escolhida em função das características próprias do ambiente e de seus membros.

Como ponto de partida para o processo de implantação do SGQ, é fundamental, antes de tudo, que seja definida uma estrutura mínima composta por um responsável (coordenador), membros (auxiliares) e um local físico (sala) com infra-estrutura e recursos de apoio (p.ex. computador e impressora). Essa equipe técnica deve ser formada por pessoal capacitado (definida e plenamente apoiada pela alta administração), sendo responsável pela condução dos trabalhos de implantação do Sistema de Gestão da Qualidade na empresa.

Como sugestão para implantação do modelo, apresenta-se um cronograma de trabalho (Tabela 10) baseado nas informações da literatura pesquisada e exemplos de programas implantados com sucesso em empresas de outros segmentos. A elaboração do cronograma depende de inúmeras variáveis que mudam de empresa para empresa, porém as atividades básicas são comuns a qualquer projeto. 
Tabela 10 - Sugestão de Cronograma para implantação do SGQ.

\begin{tabular}{|c|c|c|c|c|c|c|c|c|c|c|c|c|c|c|c|c|c|c|c|c|c|}
\hline \multirow{2}{*}{\multicolumn{2}{|c|}{ Etapa }} & \multicolumn{20}{|c|}{ Meses } \\
\hline & & 1 & 2 & 3 & 4 & 5 & 6 & 7 & 8 & 9 & 10 & 11 & 12 & 13 & 14 & 15 & 16 & 17 & 18 & 19 & 20 \\
\hline \multicolumn{22}{|c|}{1 Convencimento e Sensibilização } \\
\hline \multicolumn{22}{|c|}{2 Diagnóstico da Situação Atual } \\
\hline \multicolumn{22}{|c|}{3 Planejamento Estratégico } \\
\hline \multicolumn{22}{|c|}{4 Projeto do Processo } \\
\hline \multicolumn{22}{|c|}{5 Gerenciamento Sistêmico } \\
\hline \multicolumn{22}{|c|}{6 Avaliação e Suporte } \\
\hline 7 & $\begin{array}{l}\text { Gestão e Manutenção da } \\
\text { Qualidade }\end{array}$ & & & & & & & & & & & & & & & & & & & & \\
\hline
\end{tabular}

\section{4 - ELEMENTOS CONSIDERADOS PARA ELABORAÇÃO DO MODELO PROPOSTO}

São relacionados a seguir os elementos da empresa genérica GPSAT que foram considerados para o desenvolvimento da proposta modelo.

\subsection{1 - Informações de Entrada}

Nas informações de entrada foi considerado que a empresa é uma organização nova e com grande motivação por parte da alta administração (donos) para implantar um sistema de Gestão da Qualidade visando à melhoria dos serviços e à diminuição dos custos produtivos para atender principalmente o mercado de georrefenciamento.

\section{Diagnóstico do Ambiente Externo}

O diagnóstico do ambiente externo é apresentado na Tabela 11 de forma sintetizada, incluindo o cenário atual, as oportunidades e as ameaças para a empresa. 
Tabela 11 - Diagnóstico do Ambiente Externo - GPSAT

\section{Ambiente Externo}

\begin{tabular}{|c|c|c|}
\hline Cenário Atual (Descrição) & Oportunidades & Ameaças \\
\hline $\begin{array}{l}\text { Alta demanda de clientes de } \\
\text { Posicionamento com GPS } \\
\text { para georreferenciamentos, } \\
\text { SIG e mapeamentos. }\end{array}$ & $\begin{array}{l}\text { - Aumento da oferta de } \\
\text { serviços com GPS. } \\
\text { - Criação de mais equipes } \\
\text { - Melhoria da qualidade dos } \\
\text { serviços. }\end{array}$ & $\begin{array}{l}\text { - Restrição orçamentária } \\
\text { (recursos humanos, } \\
\text { físicos, equipamentos e } \\
\text { segurança) } \\
\text { - Infra-estrutura insuficiente } \\
\text { - } \quad \text { Capacitação técnica }\end{array}$ \\
\hline $\begin{array}{l}\text { Mudança política do governo } \\
\text { em relação ao financiamento à } \\
\text { pequena empresa }\end{array}$ & $\begin{array}{l}\text { - Captação de recursos } \\
\text { (Financiadoras e Bancos de } \\
\text { Desenvolvimento) }\end{array}$ & $\begin{array}{l}\text { - } \text { Elevadas taxas } \\
\text { - } \text { Aporte de recursos } \\
\text { pequeno ou insuficiente } \\
\text { - Canais de informação com } \\
\text { dados incorretos }\end{array}$ \\
\hline $\begin{array}{l}\text { Mercado de trabalho mais } \\
\text { exigente e competitivo }\end{array}$ & $\begin{array}{l}\text { - Aumento da qualificação } \\
\text { dos funcionários }\end{array}$ & - Falta de interesse \\
\hline $\begin{array}{l}\text { Crescimento das Empresas } \\
\text { entidades e setores públicos } \\
\text { no ramo }\end{array}$ & $\begin{array}{l}\text { - Demanda social por } \\
\text { profissional especialista }\end{array}$ & $\begin{array}{l}\text { - Saturação do mercado de } \\
\text { trabalho }\end{array}$ \\
\hline $\begin{array}{l}\text { Reconhecimento da empresa } \\
\text { no cenário Regional e } \\
\text { Nacional }\end{array}$ & $\begin{array}{l}\text { - Atrair serviços em nível } \\
\text { local, regional e nacional } \\
\text { - Alta qualificação técnica do } \\
\text { pessoal } \\
\text { - Ampliação da empresa }\end{array}$ & $\begin{array}{l}\text { - Ausência de recursos de } \\
\text { capital para investimento. }\end{array}$ \\
\hline $\begin{array}{l}\text { Aumento da valorização dos } \\
\text { serviços pela sociedade }\end{array}$ & $\begin{array}{l}\text { - Oferta de serviços de } \\
\text { qualidade }\end{array}$ & \\
\hline $\begin{array}{l}\text { Ausência de uma carreira } \\
\text { atrativa para os funcionários }\end{array}$ & $\begin{array}{l}\text { - Desenvolvimento de um } \\
\text { plano de carreiras }\end{array}$ & $\begin{array}{l}\text { - Evasão dos funcionários } \\
\text { qualificados }\end{array}$ \\
\hline
\end{tabular}

\section{Diagnóstico do Ambiente Interno}

O diagnóstico do ambiente interno também é apresentado de forma sintetizada na

Tabela 12, incluindo o cenário atual, as oportunidades e as ameaças para a empresa. 
Tabela 12 - Diagnóstico do Ambiente Interno - GPSAT

\section{Ambiente Interno}

\begin{tabular}{|c|c|c|}
\hline $\begin{array}{c}\text { Quadro Atual } \\
\text { (Situação da GPSAT) }\end{array}$ & Pontos Fortes & Pontos Fracos \\
\hline $\begin{array}{l}\text { Empresa de pequeno porte } \\
\text { atuante principalmente nas } \\
\text { atividades de posicionamento } \\
\text { por satélite. }\end{array}$ & $\begin{array}{l}\text { - Corpo técnico especializado } \\
\text { - Equipamentos modernos } \\
\text { - Bem conceituada no mercado }\end{array}$ & $\begin{array}{l}\text { - Produtividade desigual entre } \\
\text { as equipes } \\
\text { - Desequilíbrio na valorização } \\
\text { das atividades de campo e } \\
\text { escritório } \\
\text { - Ausência de um sistema } \\
\text { integrado sobre as } \\
\text { informações de produção }\end{array}$ \\
\hline Recursos disponíveis & $\begin{array}{l}\text { - Instalações físicas adequadas } \\
\text { bem distribuídas e equipadas } \\
\text { - Equipamentos novos e } \\
\text { modernos. } \\
\text { - Veículos adequados } \\
\text { - Equilíbrio financeiro }\end{array}$ & $\begin{array}{l}\text { - Restrições de contratações } \\
\text { - Falta de um programa de } \\
\text { preservação e manutenção de } \\
\text { equipamentos } \\
\text { - Perda de qualidade nos } \\
\text { serviços de campo } \\
\text { - Ausência de uma estrutura } \\
\text { formal de apoio ao } \\
\text { gerenciamento }\end{array}$ \\
\hline Organização administrativa & $\begin{array}{l}\text { - Baixo custo de administração } \\
\text { - Decisões rápidas } \\
\text { - Definição clara dos deveres e } \\
\text { responsabilidades }\end{array}$ & $\begin{array}{l}\text { - Estrutura linear (rígida) } \\
\text { - Não favorece a } \\
\text { especialização } \\
\text { - Sobrecarrega a direção } \\
\text { - Exige chefes excepcionais de } \\
\text { difícil substituição }\end{array}$ \\
\hline Segurança & $\begin{array}{l}\text { - Sistema de segurança no } \\
\text { escritório. }\end{array}$ & $\begin{array}{l}\text { - Falta de segurança para os } \\
\text { equipamentos e para as } \\
\text { pessoas no campo. } \\
\text { - Insalubridade do ambiente de } \\
\text { trabalho } \\
\text { - Ausência de um programa de } \\
\text { segurança e prevenção de } \\
\text { acidentes }\end{array}$ \\
\hline Qualificação profissional & $\begin{array}{l}\text { - Responsáveis técnicos } \\
\text { altamente qualificados (todos } \\
\text { são especializados) } \\
\text { - Todos os técnicos são } \\
\text { qualificados } \\
\text { - Grande dedicação de todos os } \\
\text { funcionários } \\
\text { - Corpo de funcionários jovem }\end{array}$ & $\begin{array}{l}\text { - Necessidade de pessoal } \\
\text { técnico administrativo } \\
\text { qualificado. } \\
\text { - Falta de estrutura e ambiente } \\
\text { adequado para treinamento e } \\
\text { aperfeiçoamento. }\end{array}$ \\
\hline $\begin{array}{l}\text { Ausência de um Sistema } \\
\text { formal de gestão empresarial }\end{array}$ & & \\
\hline
\end{tabular}




\section{Estratégias e políticas}

Considerando que as empresas do setor normalmente não têm um plano estratégico formal (situação típica), a opção mais indicada seria a análise de questionários e entrevistas com os diretores da empresa. No caso da empresa genérica, adotou-se como meta o estabelecimento de um programa formal de qualidade e produtividade, considerando a redução dos custos de produção e a Garantia da Qualidade dos serviços com vistas à satisfação dos clientes.

\section{Metodologia e ferramentas da Gestão da Qualidade}

A metodologia e as ferramentas adotadas são definidas durante a fase de implantação. Considerando a empresa genérica, supõe-se a adoção do ciclo PDCA em todas as etapas e sob todos os processos. Conforme a evolução da implantação, deverão ser feitas pesquisas internas e externas considerando os resultados obtidos. Entre as principais ferramentas de análise têm-se os mapas de processo, diagramas de causa e efeito, diagramas dos por quês, gráficos de Pareto etc.

\section{Modelo de referência adotado}

Como modelo de referência para o desenvolvimento e a implantação do programa, consideraram-se as diretrizes propostas pelas normas da serie ISO 9000:2000.

\subsection{2 - Documentos da Qualidade}

Os documentos da empresa genérica de posicionamento com GPS - GPSAT foram elaborados pelo autor, seguindo os critérios estabelecidos pelas normas de referência, e considerados apenas como modelo:

- Organograma;

- planta básica do escritório;

- macroprocesso LGPS - Posicionamentos com GPS;

o fluxograma operacional básico de um posicionamento com GPS;

o unidade de negócio;

o indicadores da qualidade;

o objetivos e metas da qualidade;

o árvore de macroprocessos;

o mapas de macroprocessos;

- mapas de processos. 


\subsubsection{1 - Organograma}

Representa esquematicamente a estrutura social, dispondo os elementos componentes da organização em extratos de autoridade e relacionamento hierárquico-funcional.

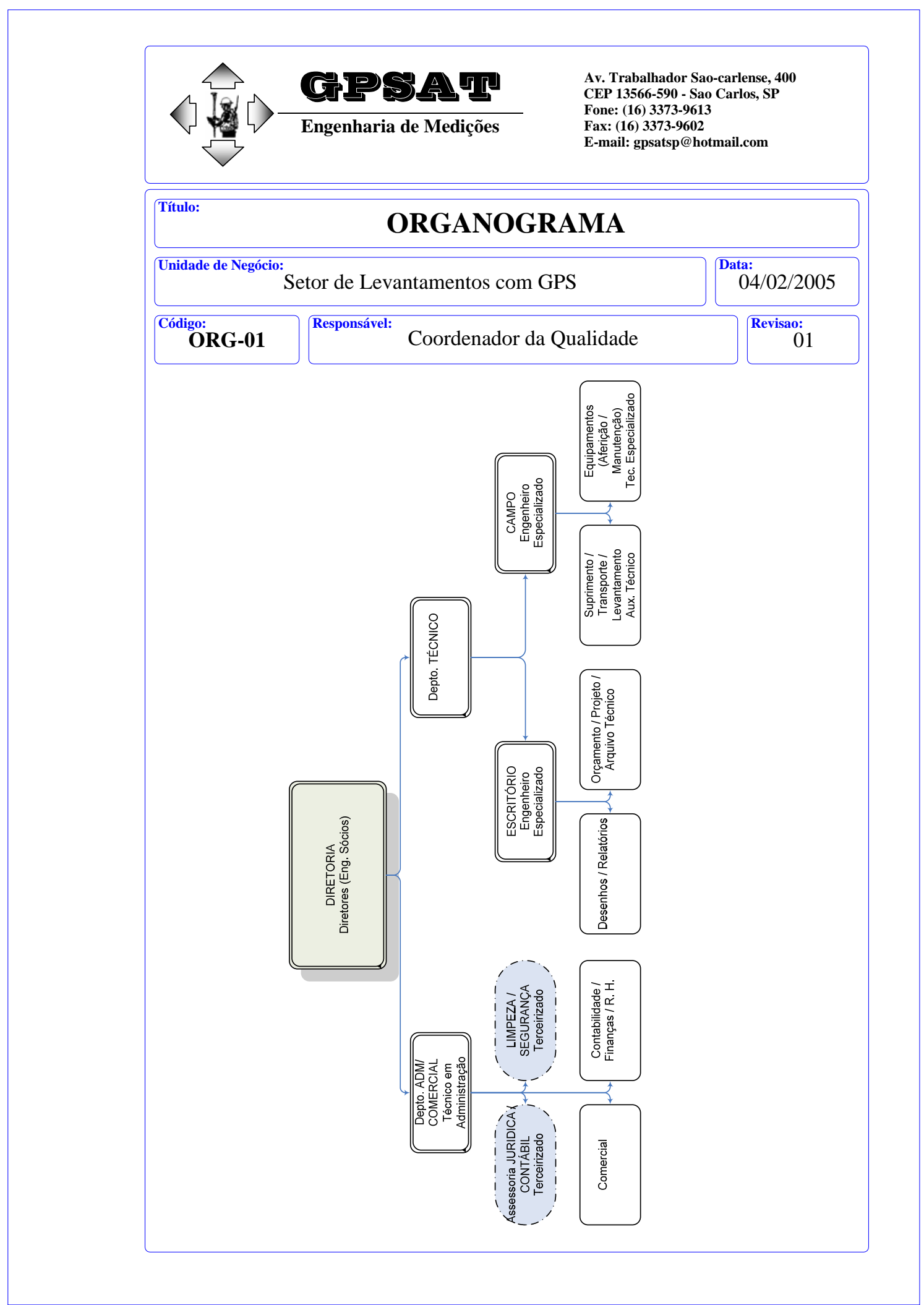

Figura 35 - Gráfico de Organização da empresa GPSAT 


\subsubsection{2 - Planta básica do Empreendimento GPSAT}

Representação gráfica da empresa considerando os elementos constituintes da parte física do imóvel sede.

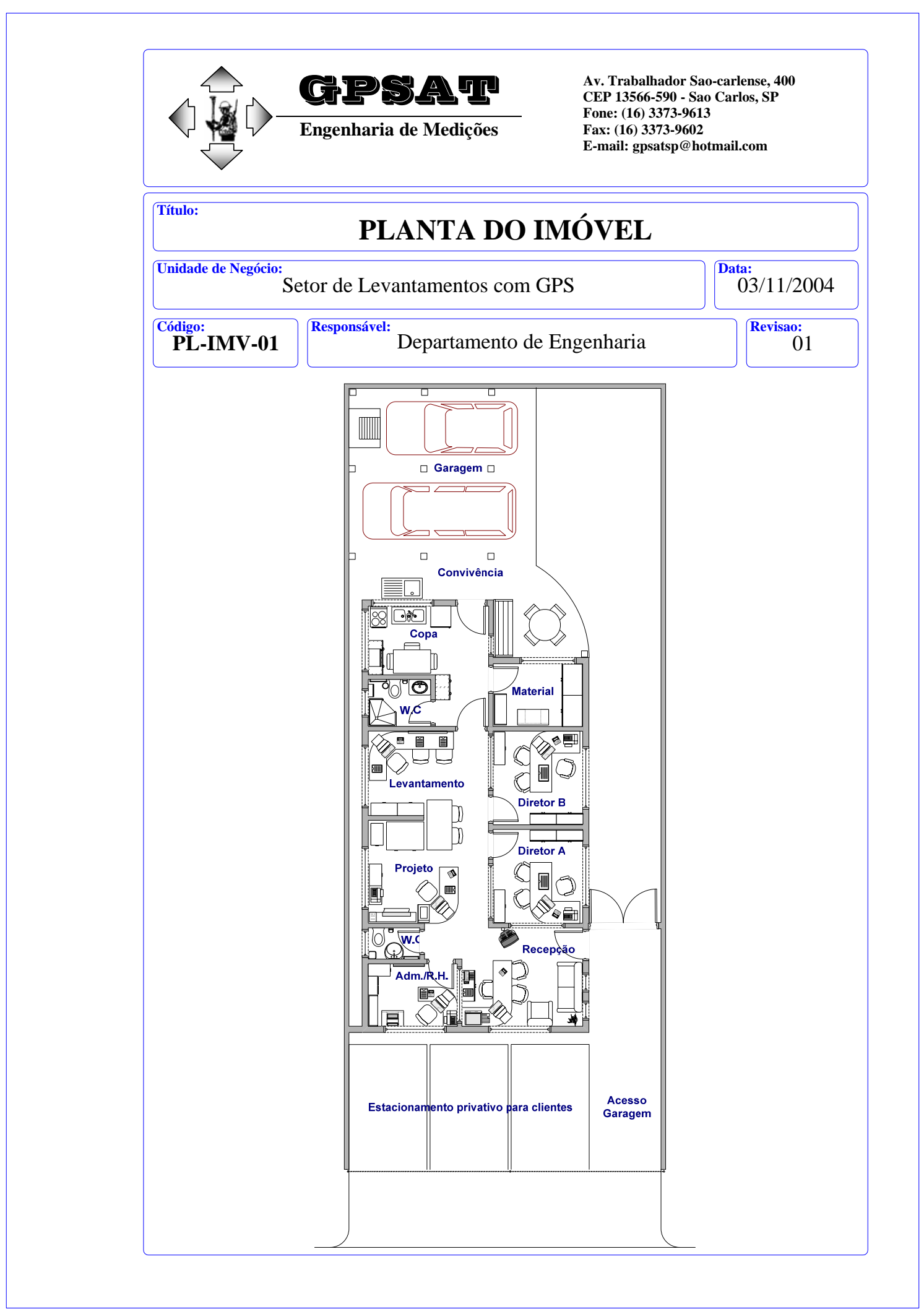

Figura 36 - Planta da empresa GPSAT 


\subsubsection{3 - Macroprocesso LGPS - Posicionamentos com GPS}

Capa do Macroprocesso relacionado ao setor de atividade da empresa

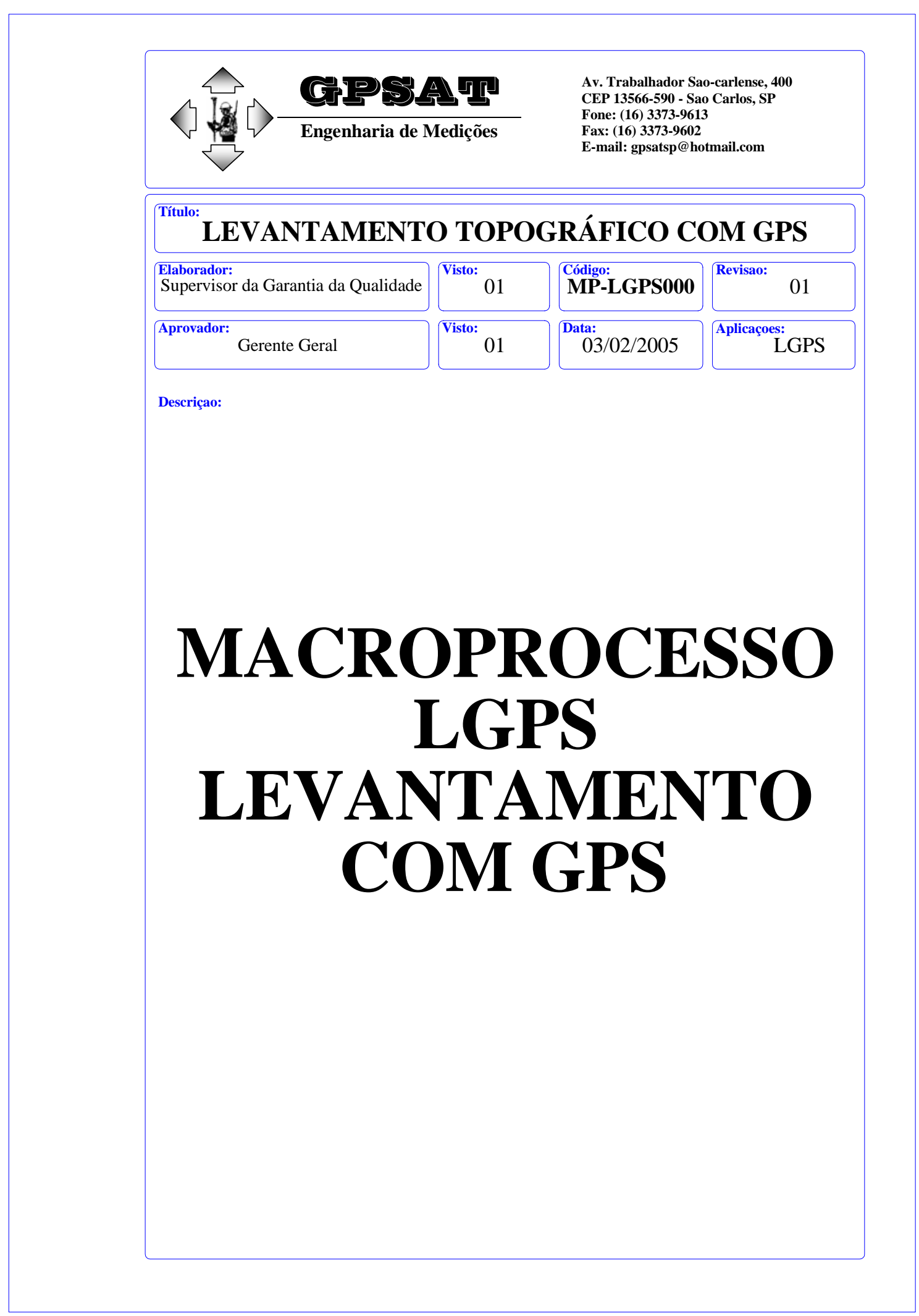

Figura 37 - Macroprocesso LGPS - GPSAT 


\section{a) Fluxograma operacional}

As atividades principais de um posicionamento com GPS podem ser representadas pelo fluxograma operacional básico (Figura 38) (sugestão do autor).

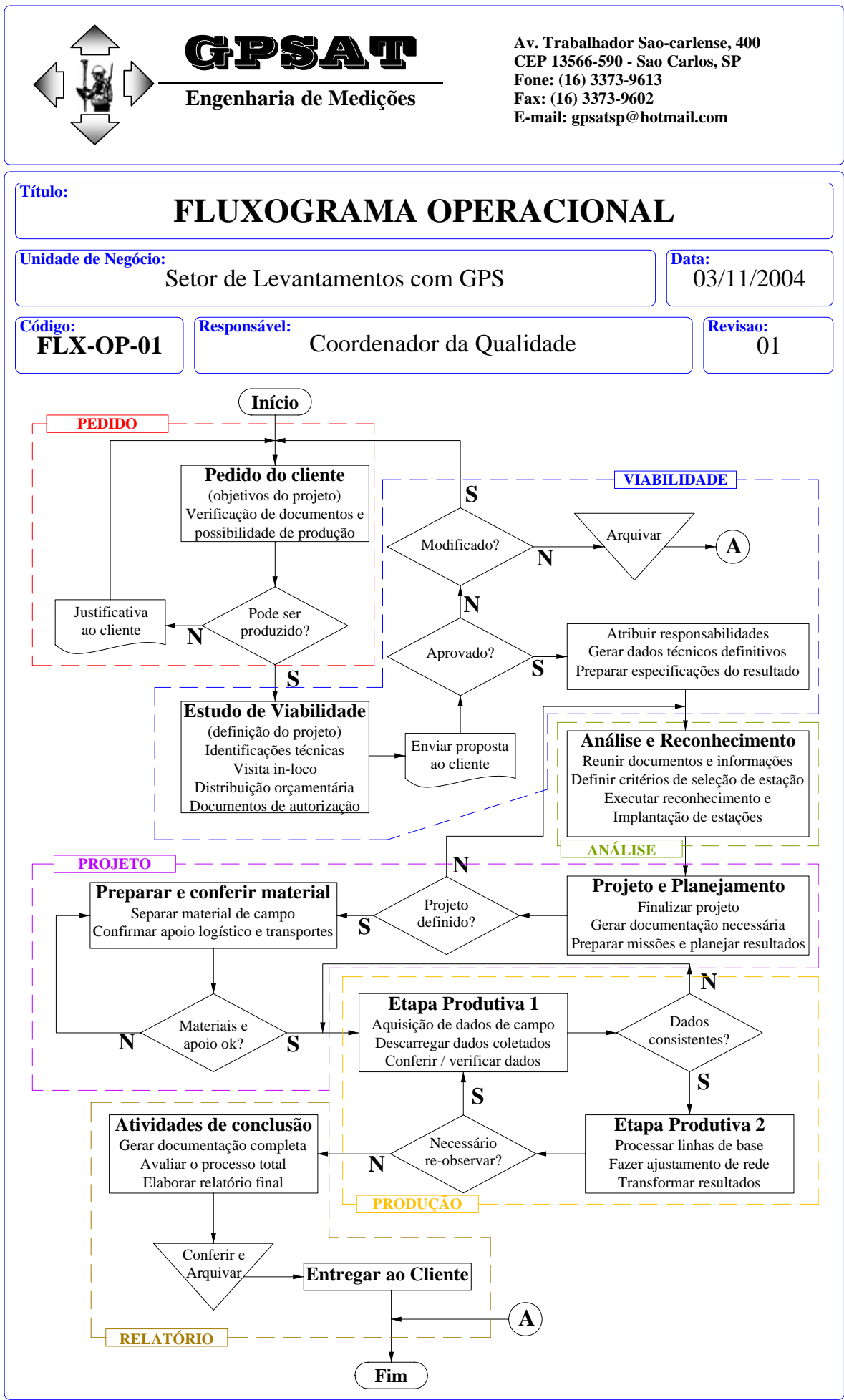


b) Unidade de negócio

É a unidade organizacional, com definição de autoridade sobre os processos afins e responsabilidade sobre resultados operacionais, que contribui para a realização da missão da empresa.

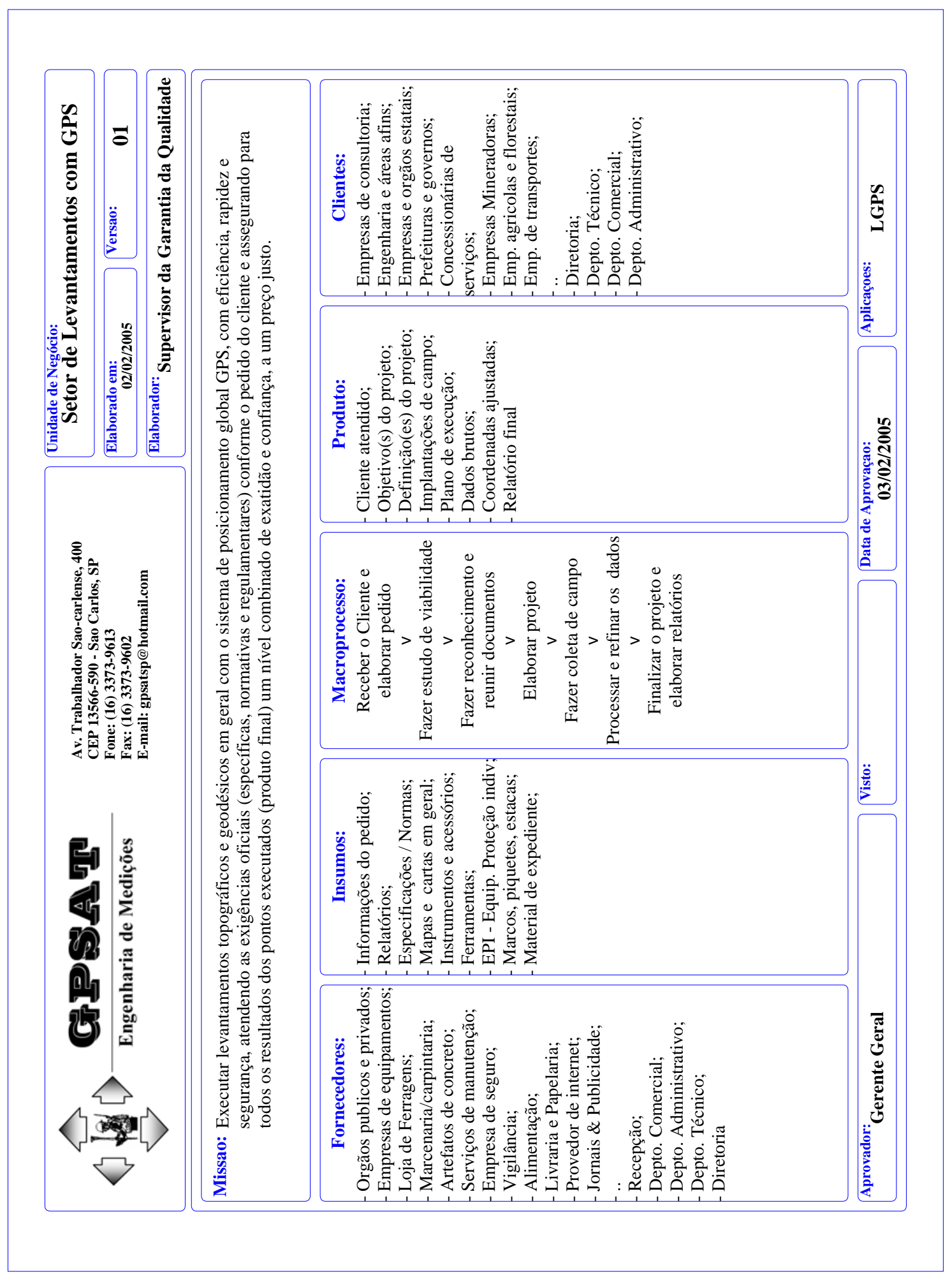

Figura 39 - Representação da Unidade Organizacional GPSAT 


\section{c) Indicadores da Qualidade}

Representam de forma quantificável a qualidade relativa do processo ou sistema, isto é, o grau e a freqüência de conformidades com os requisitos válidos para os clientes.

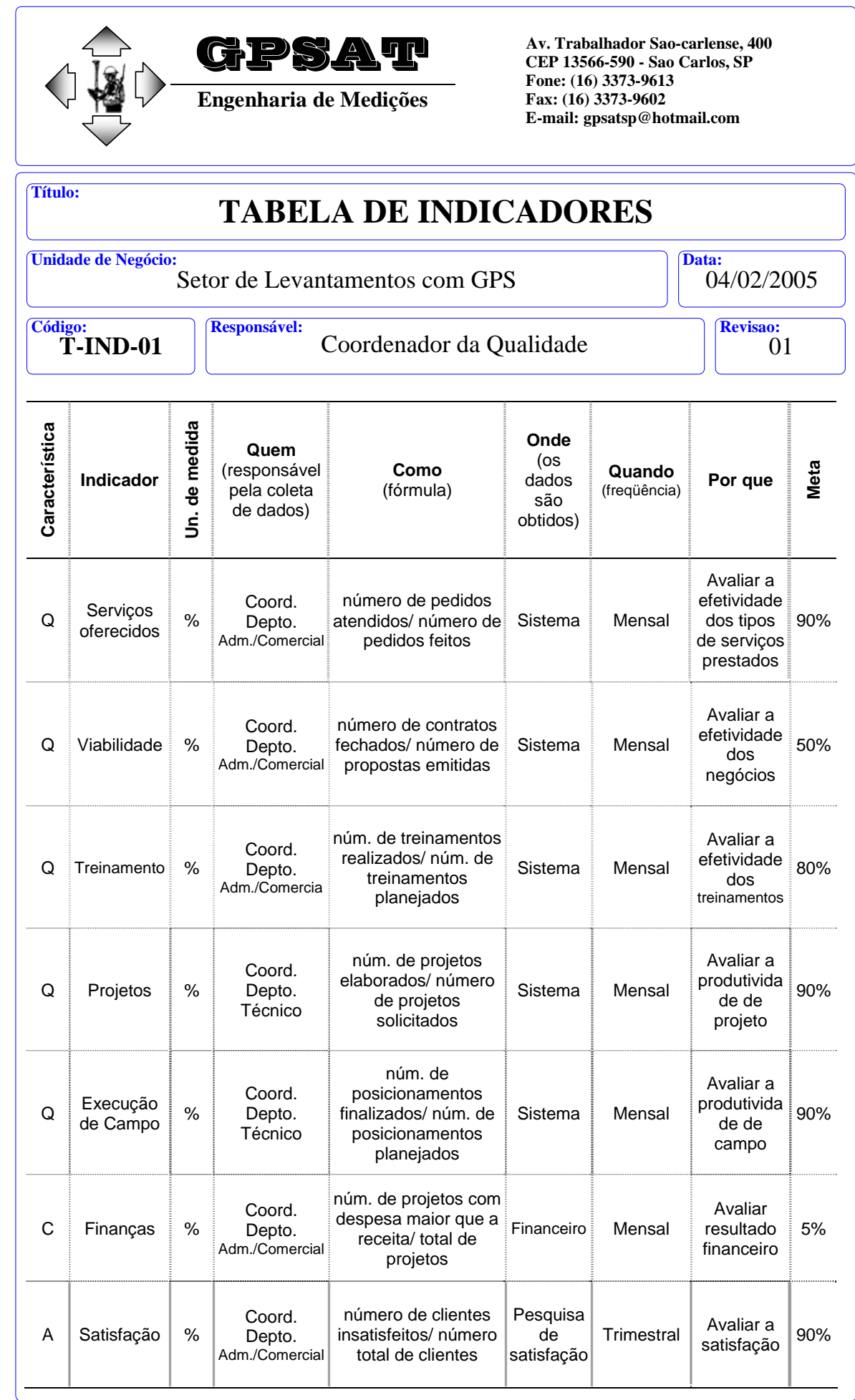

Figura 40 - Relação de Indicadores da Qualidade 


\section{d) Objetivos e metas da qualidade}

Os objetivos indicam o que se pretende atingir, enquanto a meta informa o quanto e quando se pretende atingir esse objetivo.

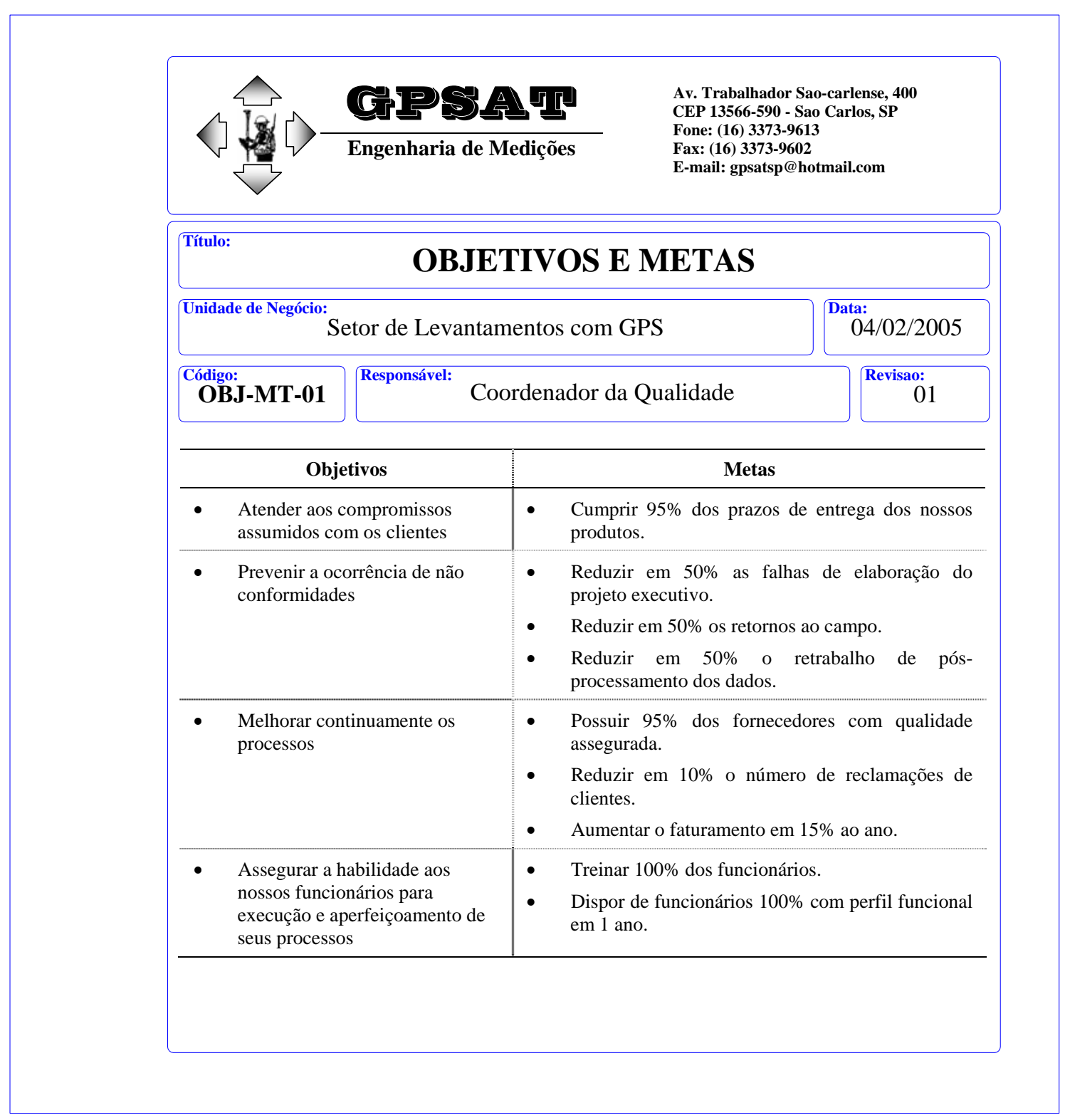

\section{Figura 41 - Objetivos e metas da Qualidade}

\section{e) Mapeamento dos processos}

O mapeamento dos processos foi feito utilizando como recursos computacionais o software Office VISIO Professional 2003 da Microsoft e analisado, posteriormente, no software BPwim “Allfusion Process Modeler” versão 4.1.4 da CA Computer Associates, gentilmente cedido para avaliação. 
A representação dos processos segue o principio normativo de mapeamento de processos considerando a simbologia de elaboração de fluxogramas (Tabela 8) e ainda:

A-0 Diagrama de contexto (ou nível 0).

So Primeiro nível de detalhamento de um macroprocesso, referente às atividades de gestão do sistema.

$\mathrm{S}_{1,2, \ldots, \text { a }} \quad$ Detalhamento do diagrama S0.

$\mathbf{S}_{\text {a.1, 2,.., b }}$ Detalhamento do diagrama $S_{a}$ referente às atividades de gestão do sistema.

A0 Primeiro nível de detalhamento de um macroprocesso, referente às atividades de realização do produto ou serviço.

$\mathbf{A}_{1,2, \ldots, \text { a }}$ Detalhamento do diagrama A0

$\mathbf{A}_{\text {a.1, 2,..., b }}$ Detalhamento do diagrama $A_{a}$ referente às atividades de realização do produto ou serviço.

Ro Primeiro nível de detalhamento de um macroprocesso, referente às atividades de gestão de recursos.

$\mathbf{R}_{\mathbf{1}, 2, \ldots, \text { a }}$ Detalhamento do diagrama R0

$\mathbf{R}_{\text {a.1, 2,..., b }}$ Detalhamento do diagrama $\mathrm{R}_{\mathrm{a}}$ referente às atividades de gestão de recursos.

\section{f) Árvore de Macroprocesso}

Os macroprocessos da empresa GPSAT considerados foram:

$A-0$ Representa o Macroprocesso LGPS (levantamento com GPS)

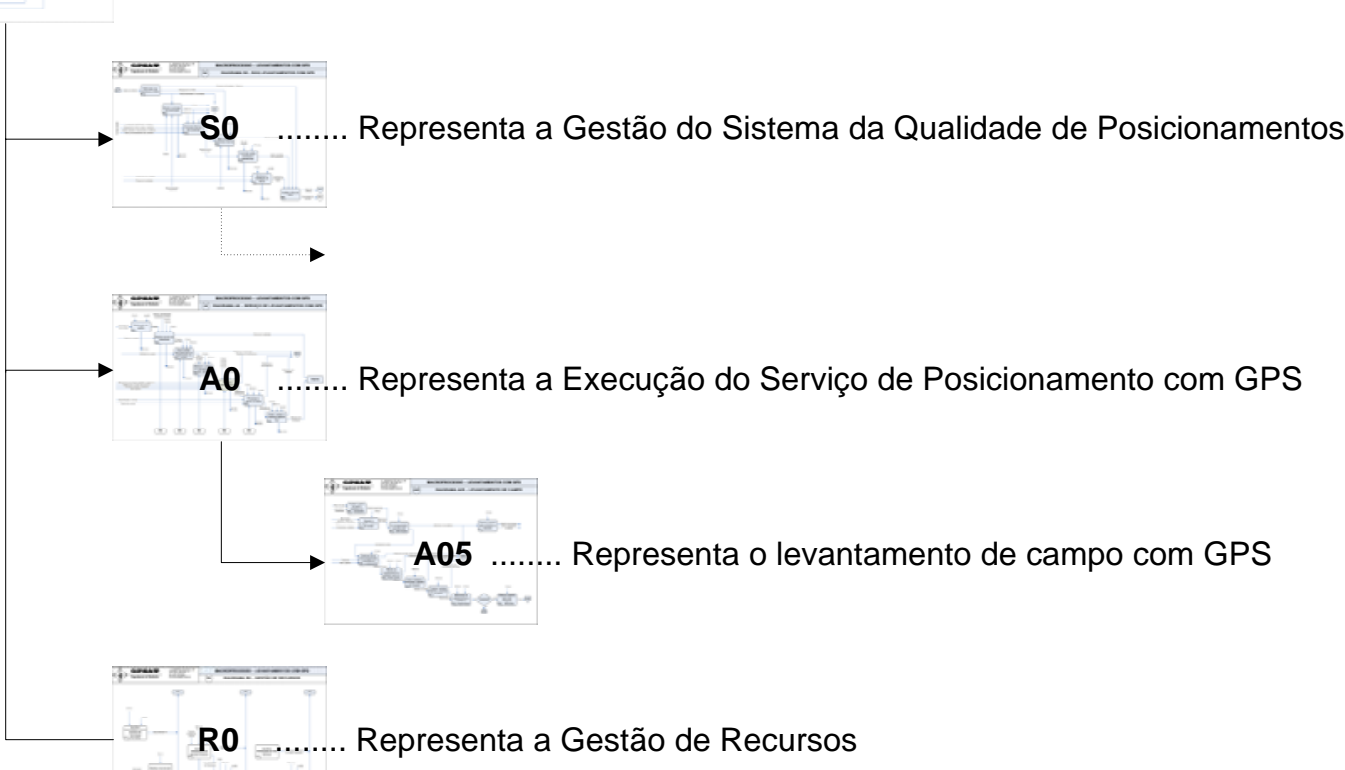




\section{g) Mapas de Macroprocessos}

Os mapas dos macroprocessos elaborados são apresentados a seguir e consideram as seguintes abreviaturas (Tabela 13).

\section{Tabela 13 - Legenda dos macroprocessos:}

\begin{tabular}{l|l}
\hline LNT & Posicionamento de necessidade de treinamento \\
\hline SGQ & Sistema de Gestão da Qualidade \\
\hline IT xx & Instrução de trabalho \\
\hline PO xx & Procedimento operacional \\
\hline MQ xx & Manual da Qualidade \\
\hline
\end{tabular}

\begin{tabular}{l:l}
\hline NC & Não conforme \\
\hline RNC & Relatório de não conformidade \\
\hline Prc & Processo \\
\hline Ind xx & Indicadores de Qualidade \\
\hline EPI & Equipamento de Proteção Individual \\
\hline
\end{tabular}

\section{h) Considerações sobre os macroprocessos elaborados}

O diagrama de contexto A - 0 (página 126) da empresa GPSAT é apresentado em 3 níveis distintos:

- O sistema de Gestão da Qualidade - S0 (página 127), que contempla o modelo proposto e fornece as diretrizes e metas da qualidade para a empresa.

- O processo de execução do serviço de levantamento - A0 (página 128), que contempla todas as etapas do ciclo de vida do serviço de posicionamento com GPS.

Por se tratar de uma representação empírica da empresa genérica GPSAT foi considerada apenas a etapa de levantamento de campo - A05 (página 129), que compõe o ciclo de vida de um posicionamento com GPS.

- O sistema de Gestão de Recursos - R0 (página 130), que contempla todos os mecanismos para aplicação dos recursos da empresa, de acordo com os níveis anteriores (este nível é apenas demonstrativo e não foi avaliado na pesquisa). 
A-0: Macroprocesso LGPS

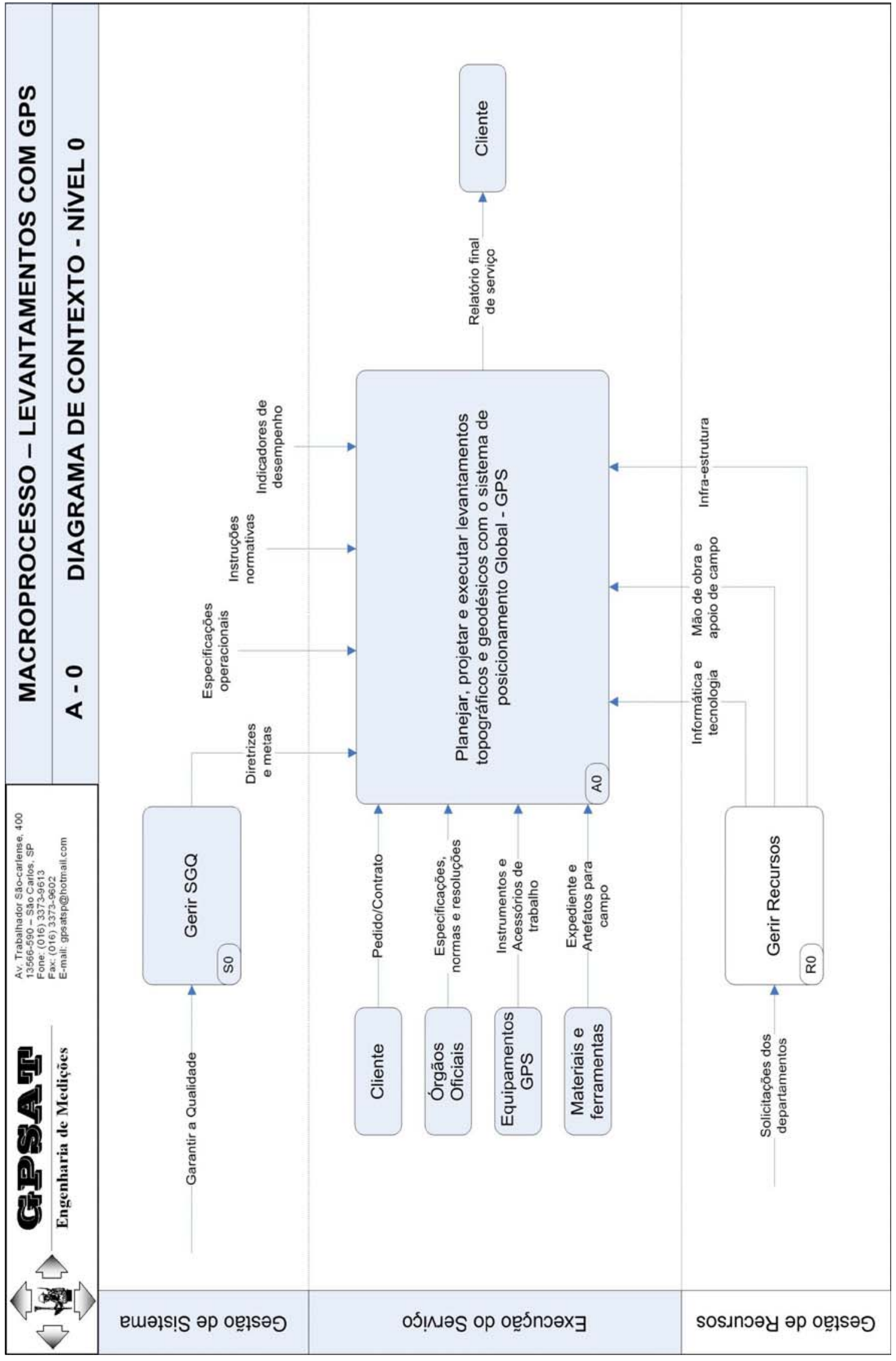


S0: Gestão de Sistema SGQ

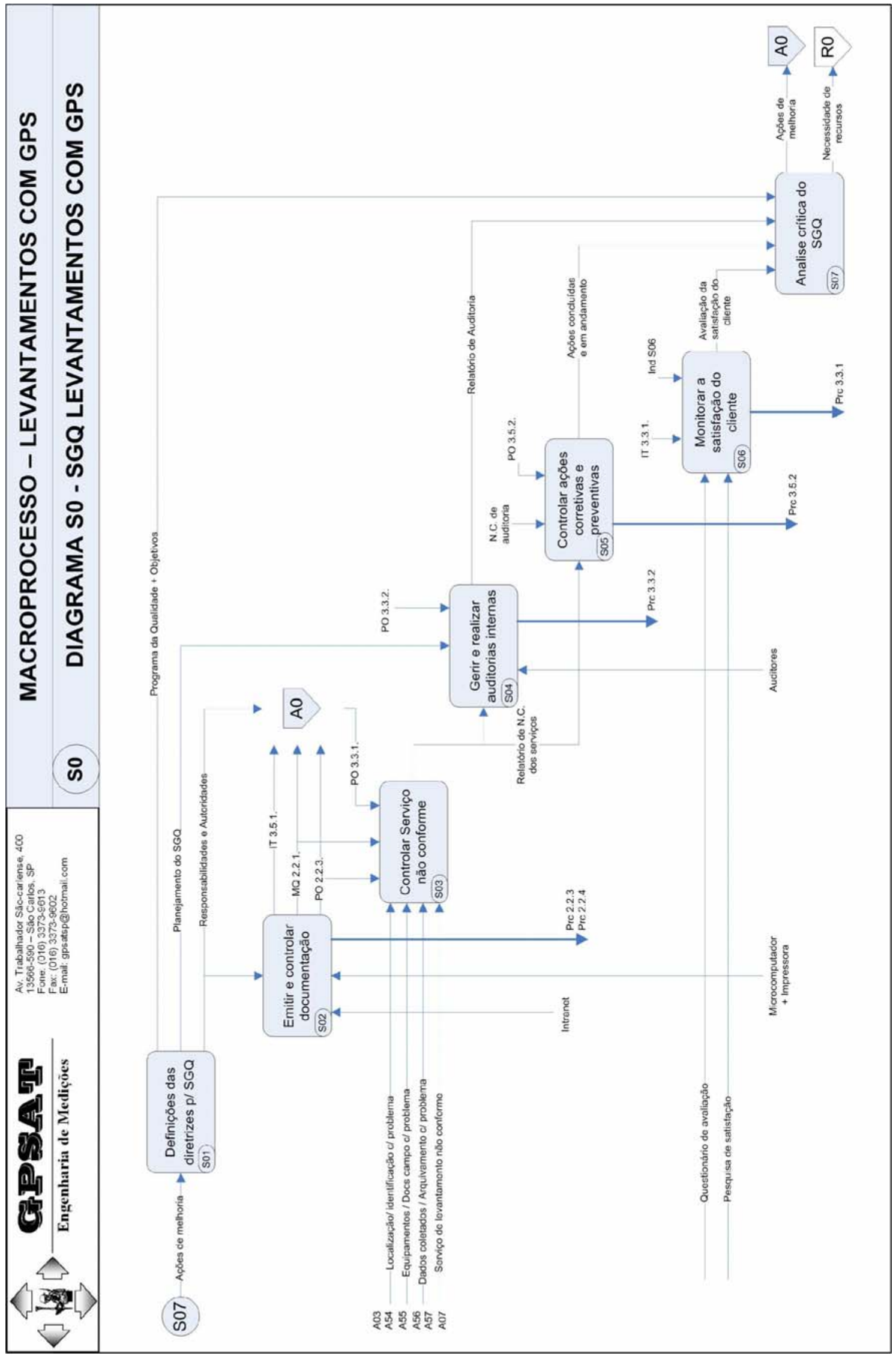


A0: Execução do serviço de posicionamento com GPS

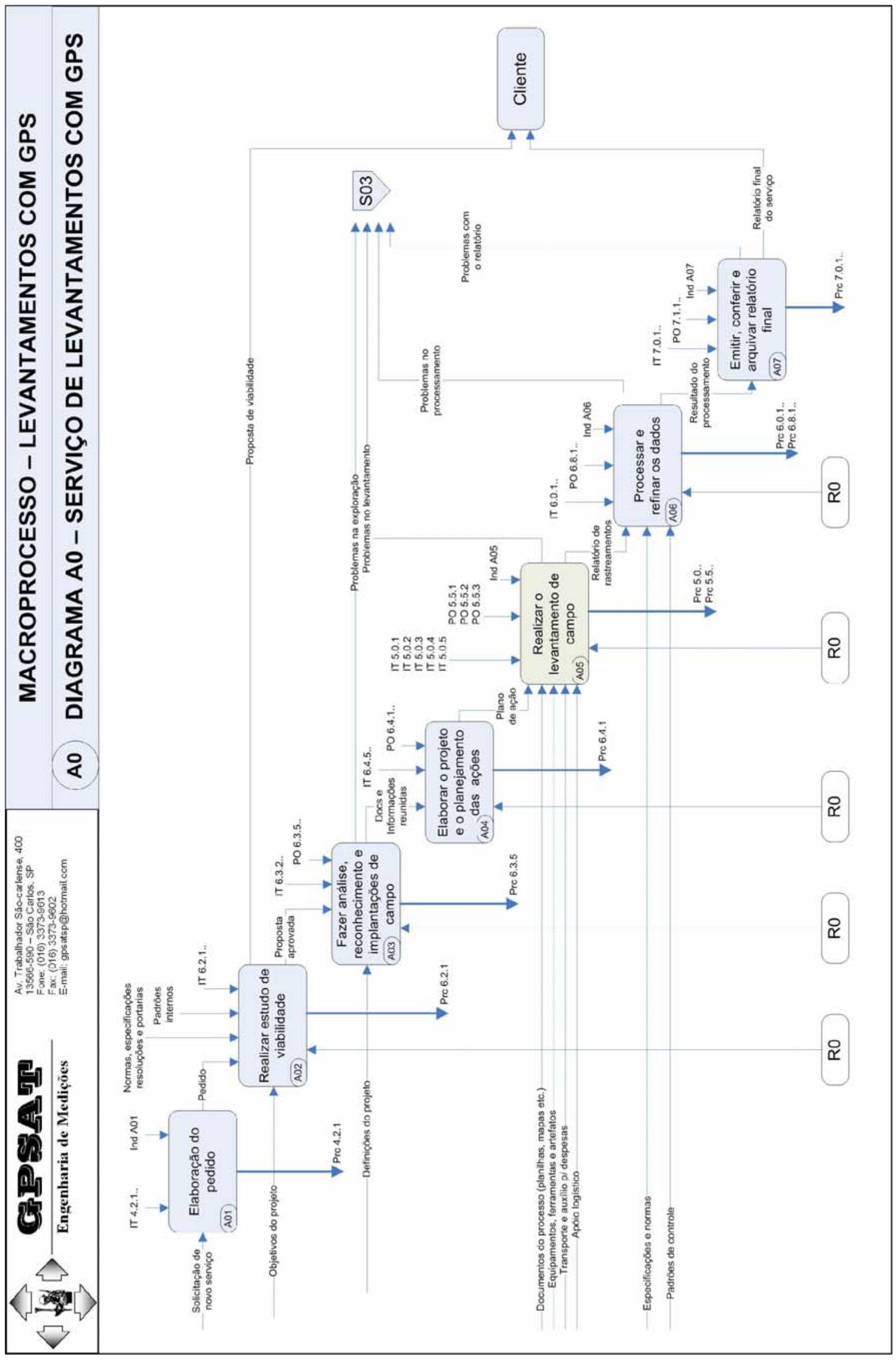


A05: Realizar levantamentos de dados no campo

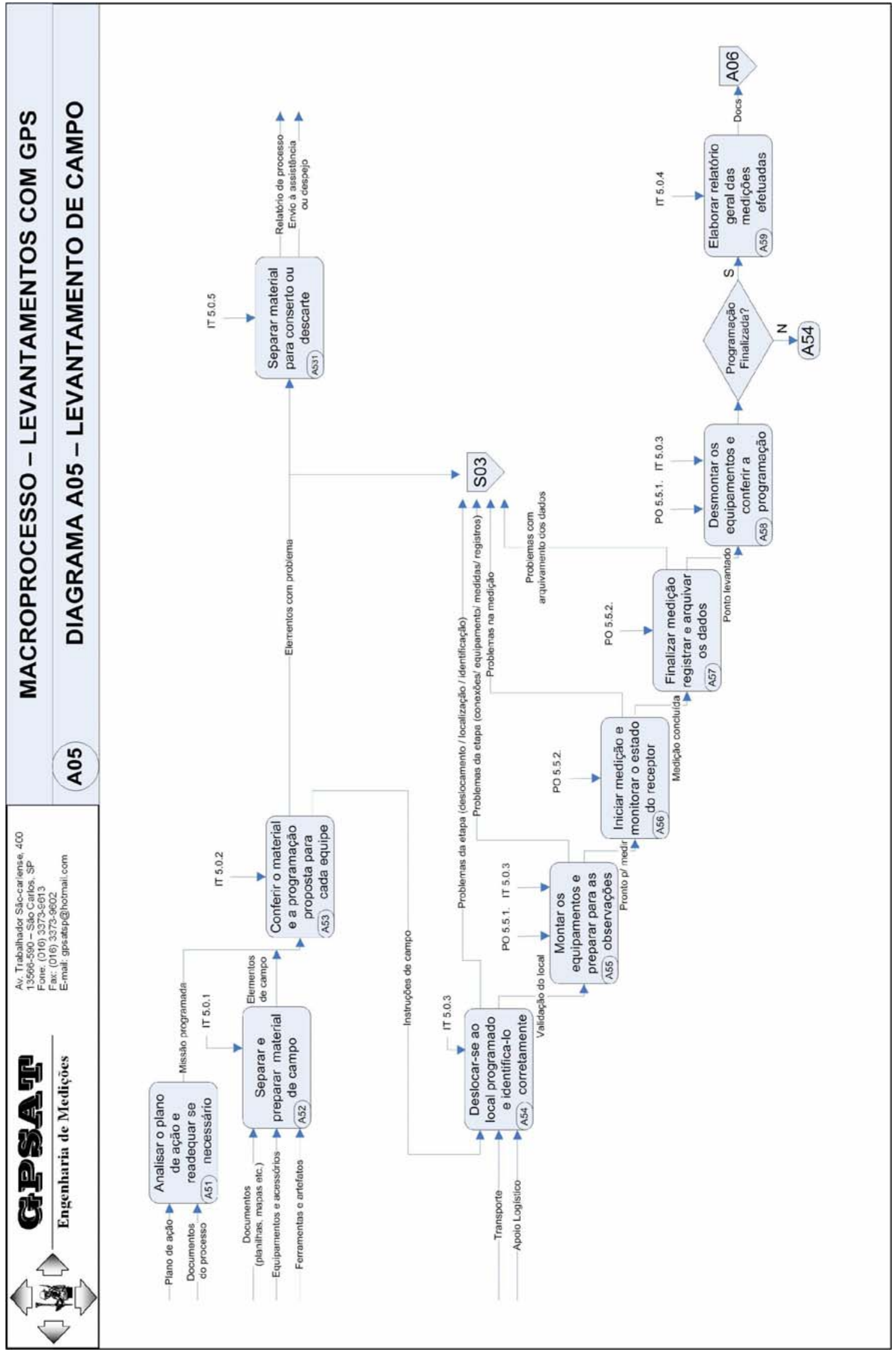


R0: Gestão de recursos

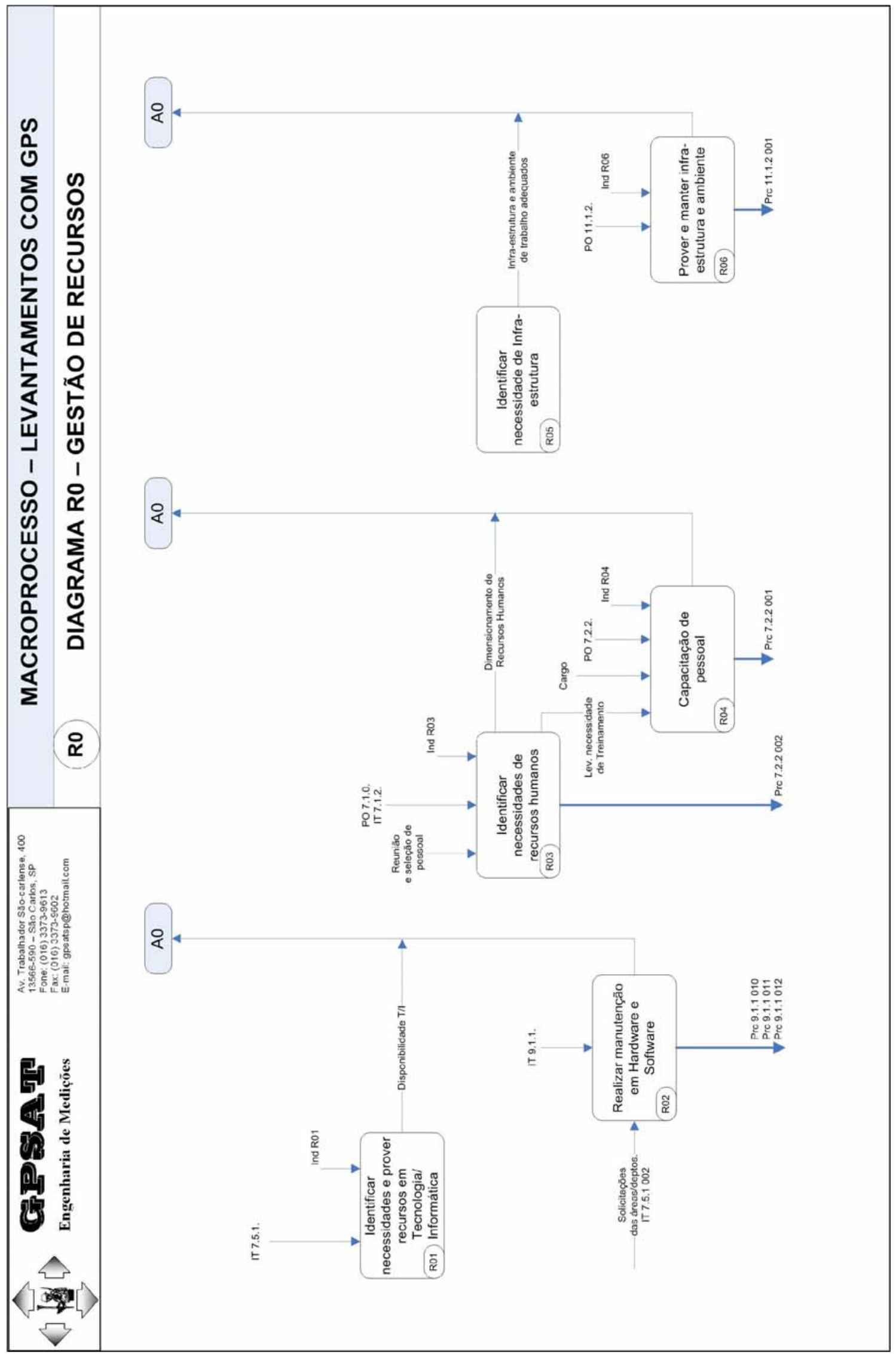




\subsubsection{4 - Mapas de processos - Prc}

Os mapas de processos apresentados referem-se apenas as principais atividades relacionadas à Gestão da organização e os serviços de posicionamento de campo. Por se tratar de uma empresa genérica (fictícia), todos os elementos e considerações também o são. Uma relação dos mapas de processos elaborados é apresentada na Tabela 14.

Tabela 14 - Descrição dos mapas de processos

\begin{tabular}{|c|c|c|}
\hline Processo & Descrição & Referenciado em: \\
\hline Prc 2.2.3 001 & Controlar documentos e dados & S02-p.127 \\
\hline Prc 2.2.4 001 & Controlar registros da qualidade & S02-p.127 \\
\hline Prc 3.3.1 001 & Satisfação do cliente & S06 - p.127 \\
\hline Prc 3.3 .2001 & Auditoria interna da qualidade & S04-p.127 \\
\hline Prc 3.5.2 001 & Ações corretivas / Ações preventivas & S05 - p.127 \\
\hline Prc 4.2.1 001 & Novo serviço & A01 - p.128 \\
\hline Prc 5.5.1 001 & Posicionamento de campo & A05-p.128 \\
\hline Prc 6.2.1 001 & Nv. Serviço - Viabilidade e proposta & A02-p.128 \\
\hline Prc 6.3.5 001 & Exploração e implantações de campo & A03-p.128 \\
\hline Prc 6.4.1 001 & Projeto e planejamento de campo & A04-p.128 \\
\hline Prc 6.8.1 001 & Processamento e refinamento dos dados & A06-p.128 \\
\hline Prc 7.1.1 001 & Relatório final de serviço & A07 - p.128 \\
\hline Prc 7.2.2 001 & Capacitar pessoal & R04 - p.130 \\
\hline
\end{tabular}

A seguir são apresentados os mapas dos processos. 
Prc 2.2.3 001: Controlar documentos e dados

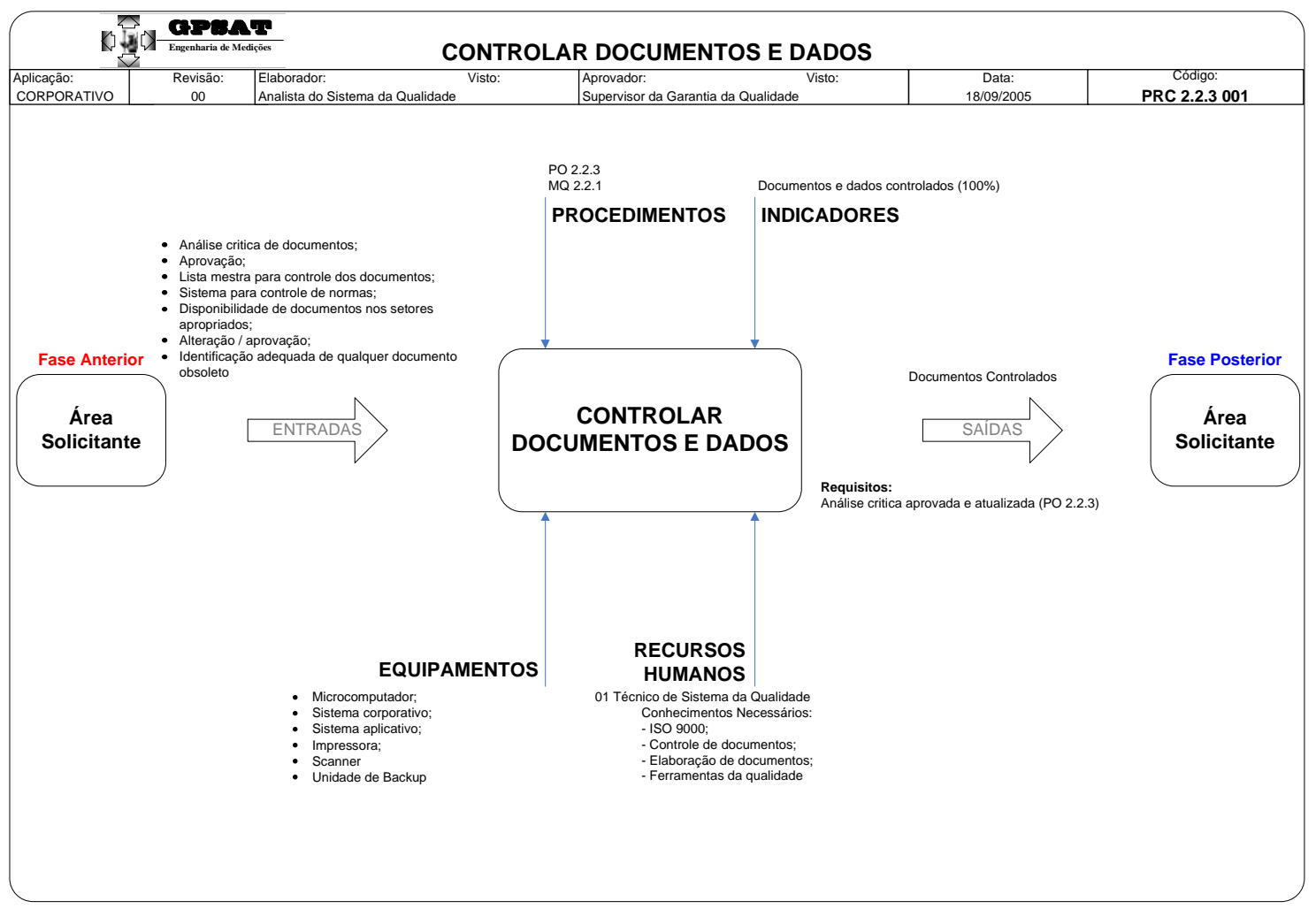

\section{Prc 2.2.4 001: Controlar registros da qualidade}

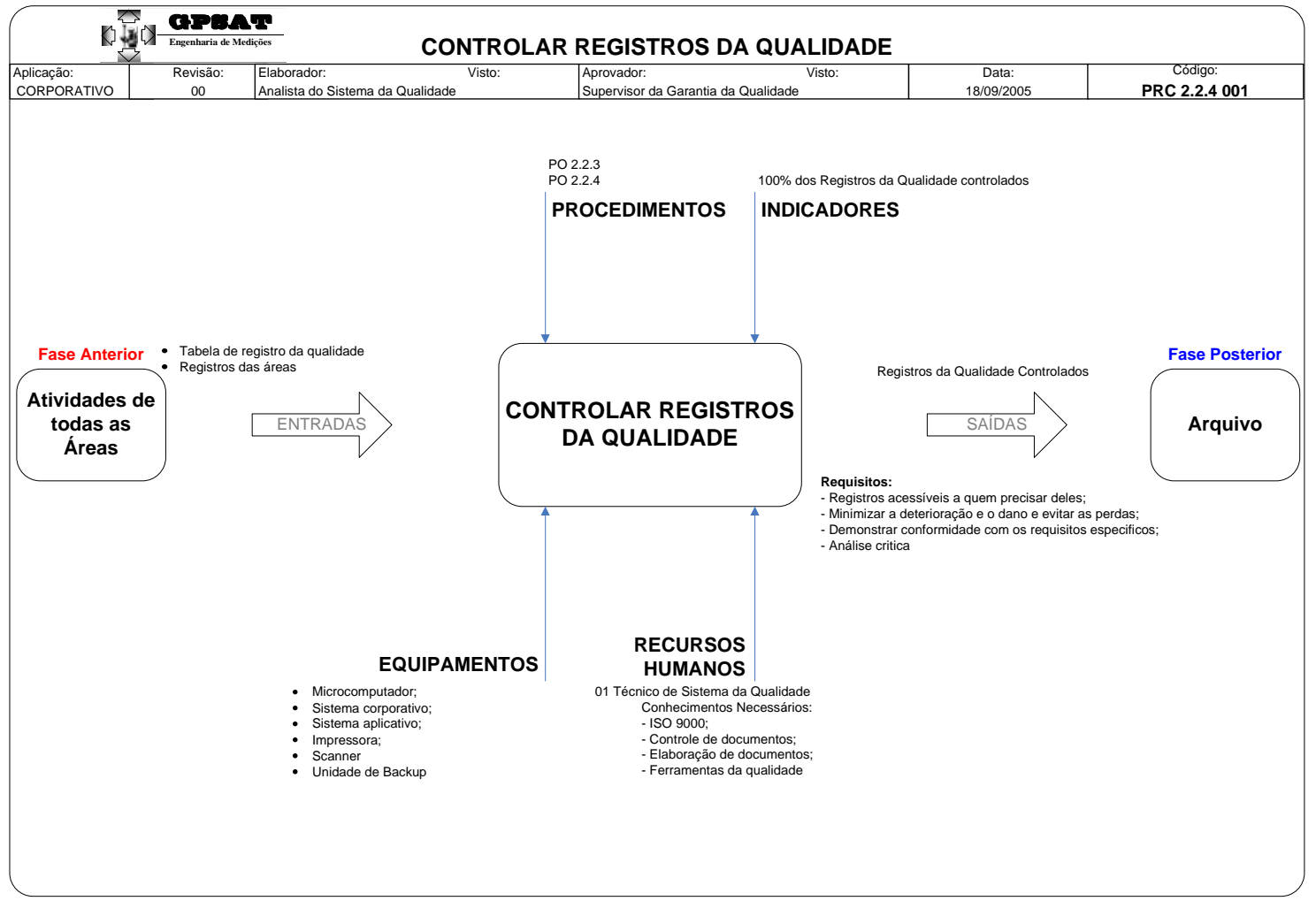


Prc 3.3.1 001: Satisfação do cliente

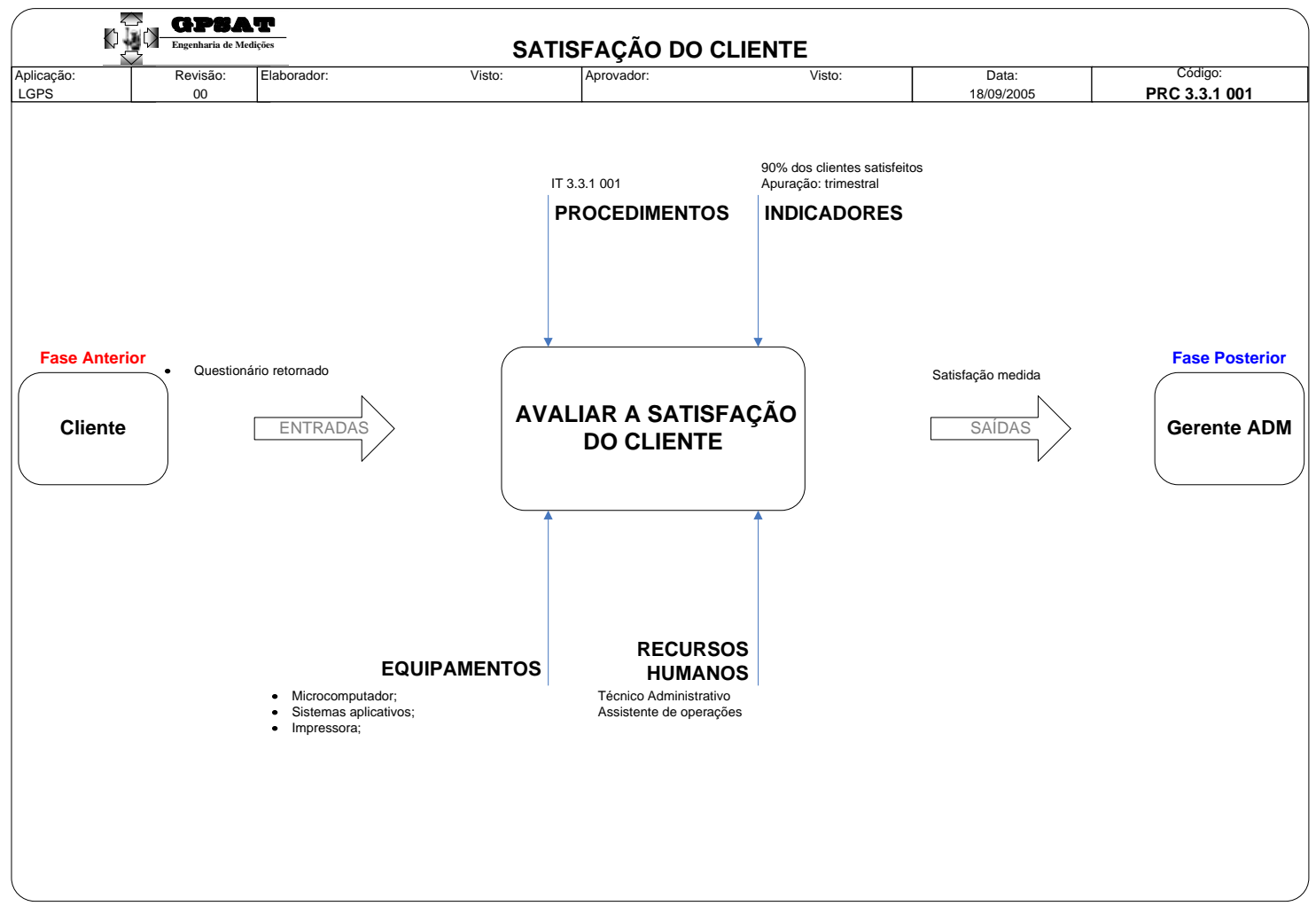

Prc 3.3.2 001: Auditoria interna da qualidade

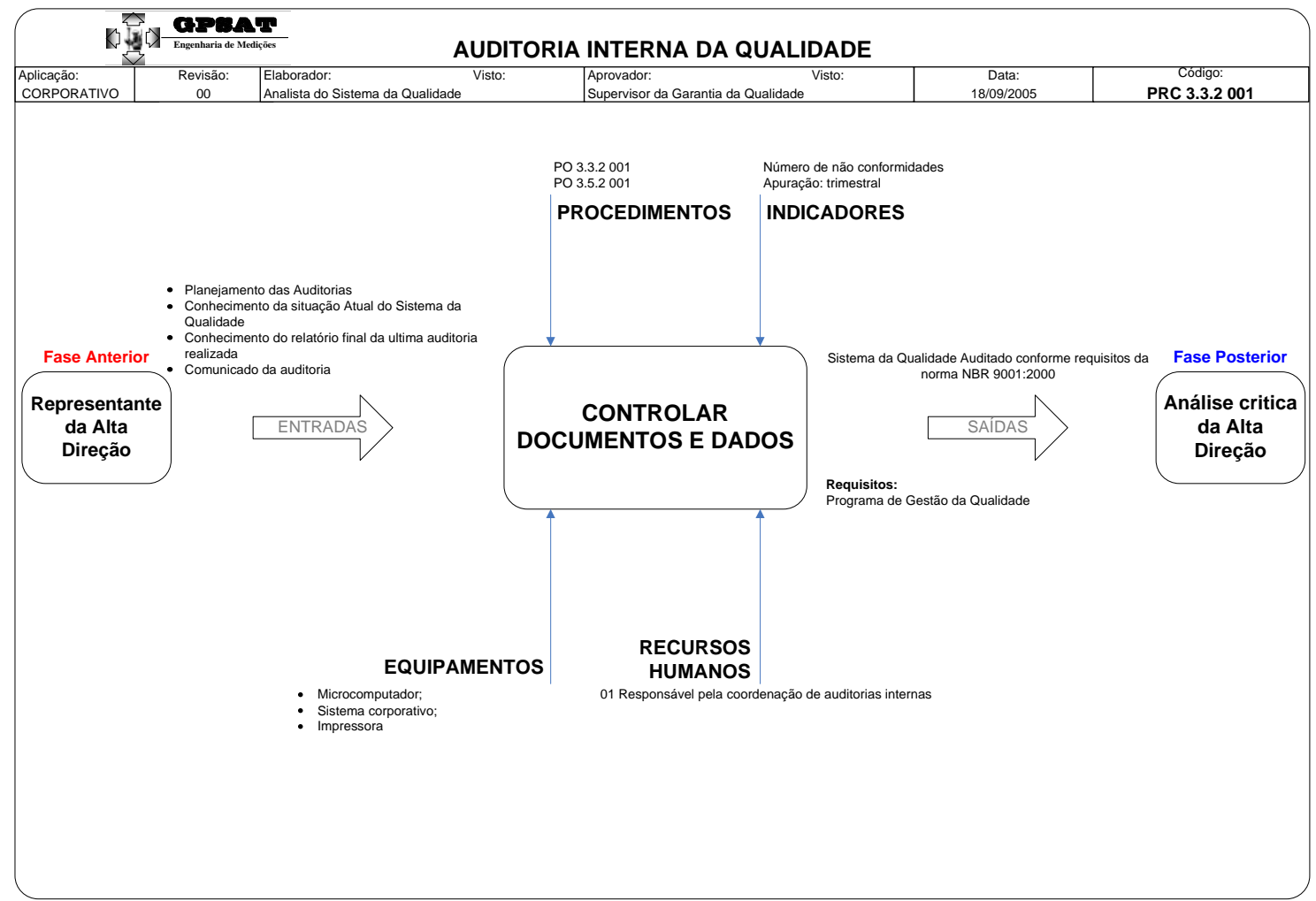


Prc 3.5.2 001: Ações corretivas / Ações preventivas

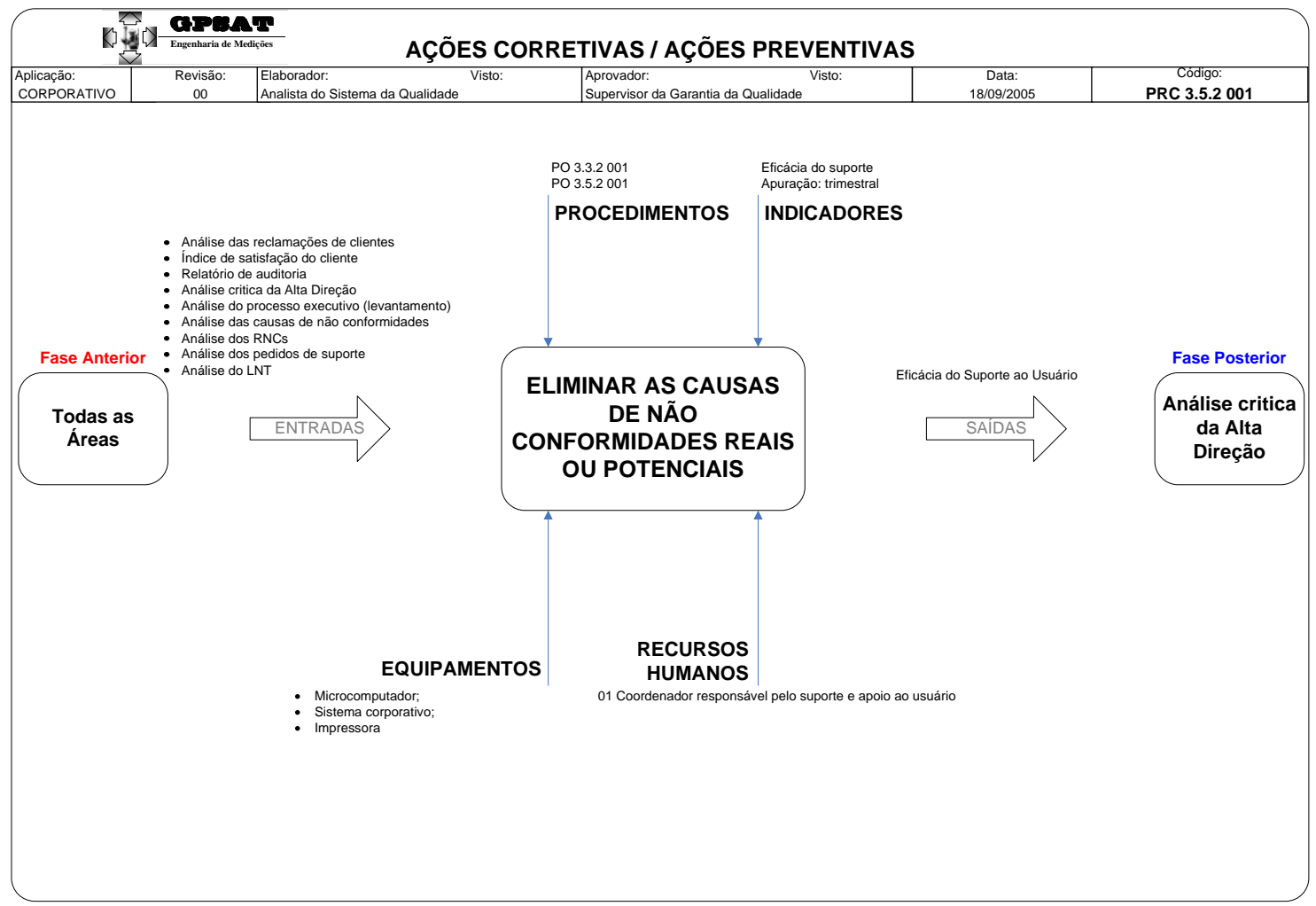

\section{Prc 4.2.1 001: Novo serviço}

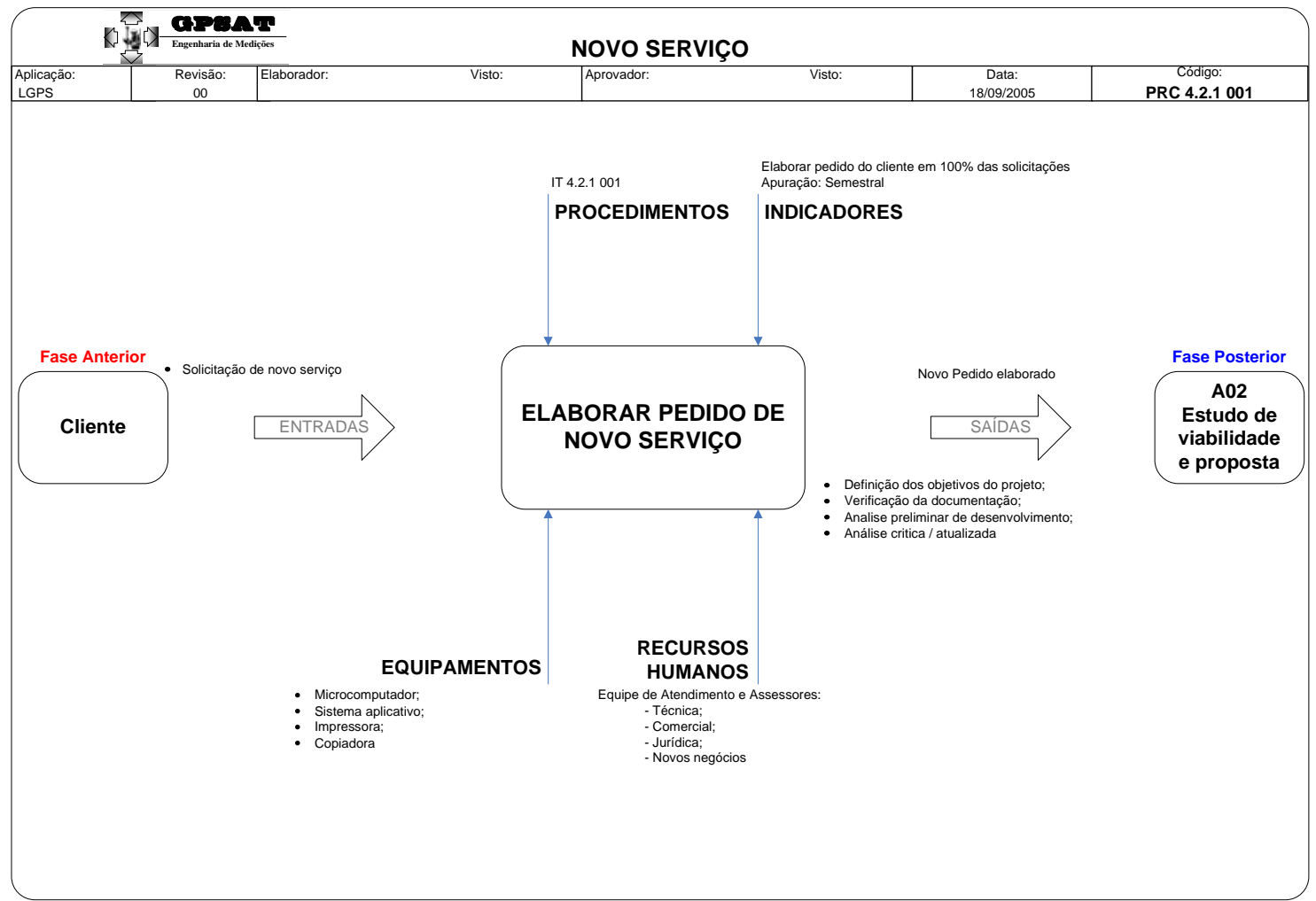


Prc 5.5.1 001: Posicionamento de campo

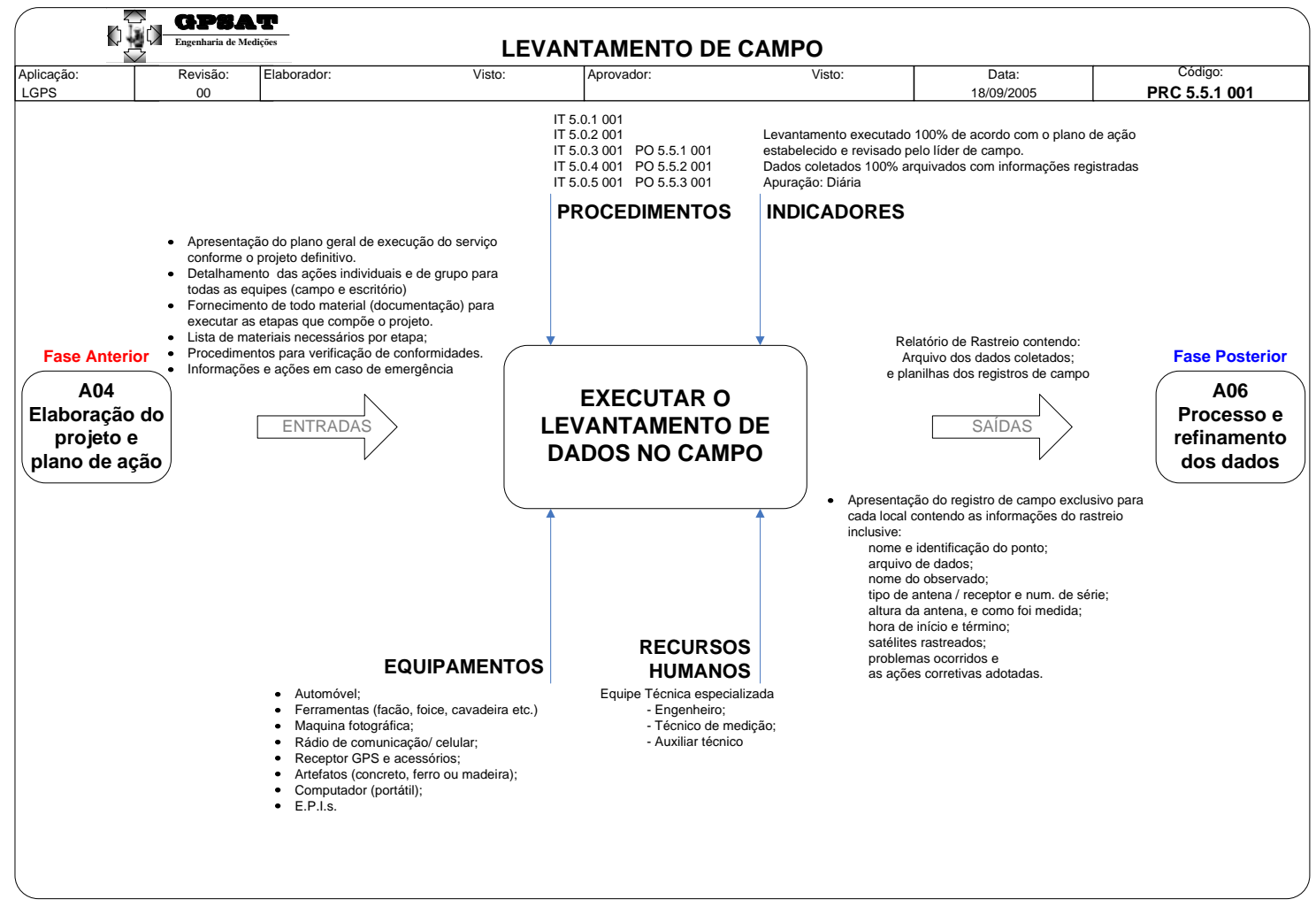

Prc 6.2.1 001: N. S. - Viabilidade e proposta

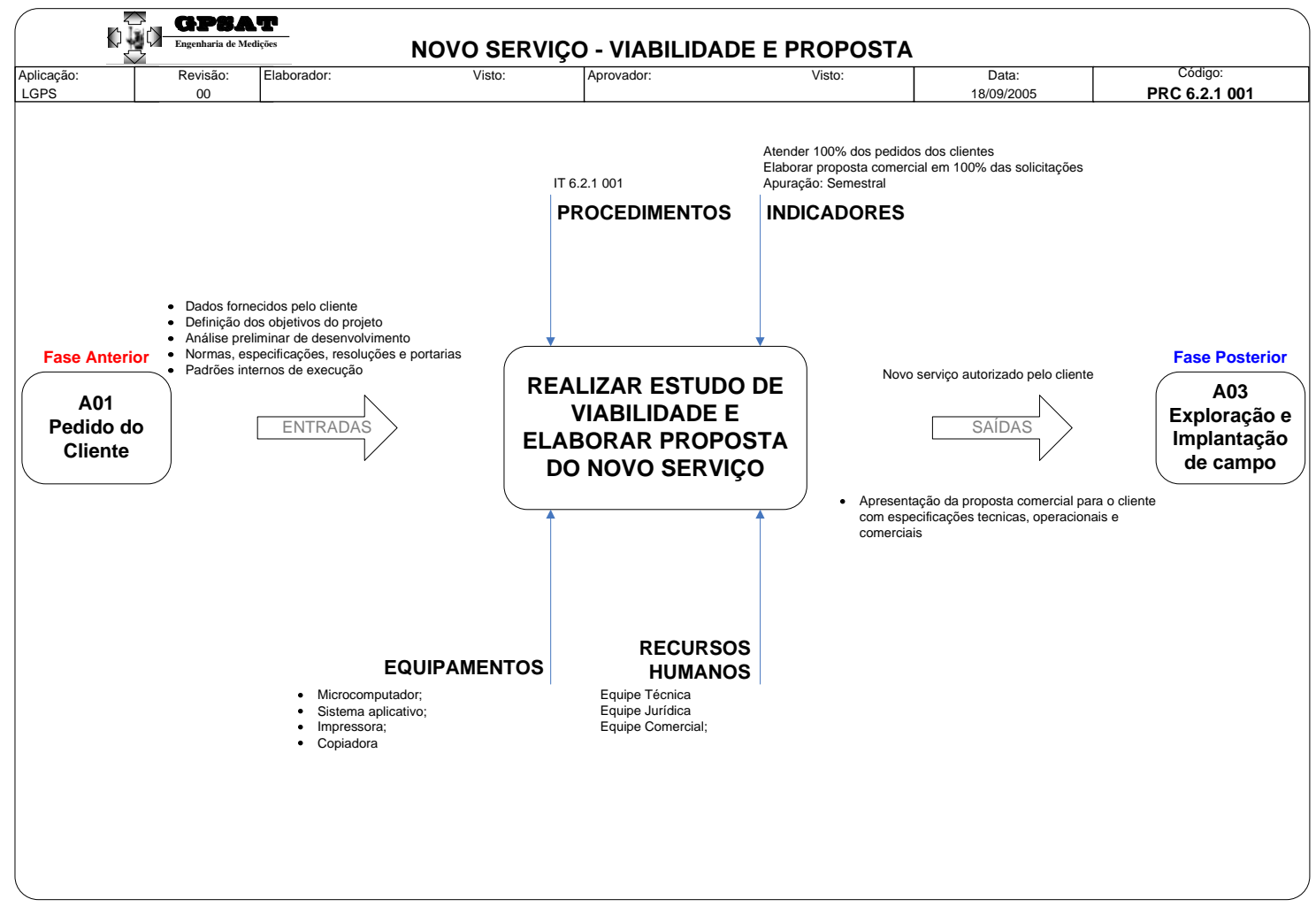


Prc 6.3.5 001: Exploração e implantações de campo

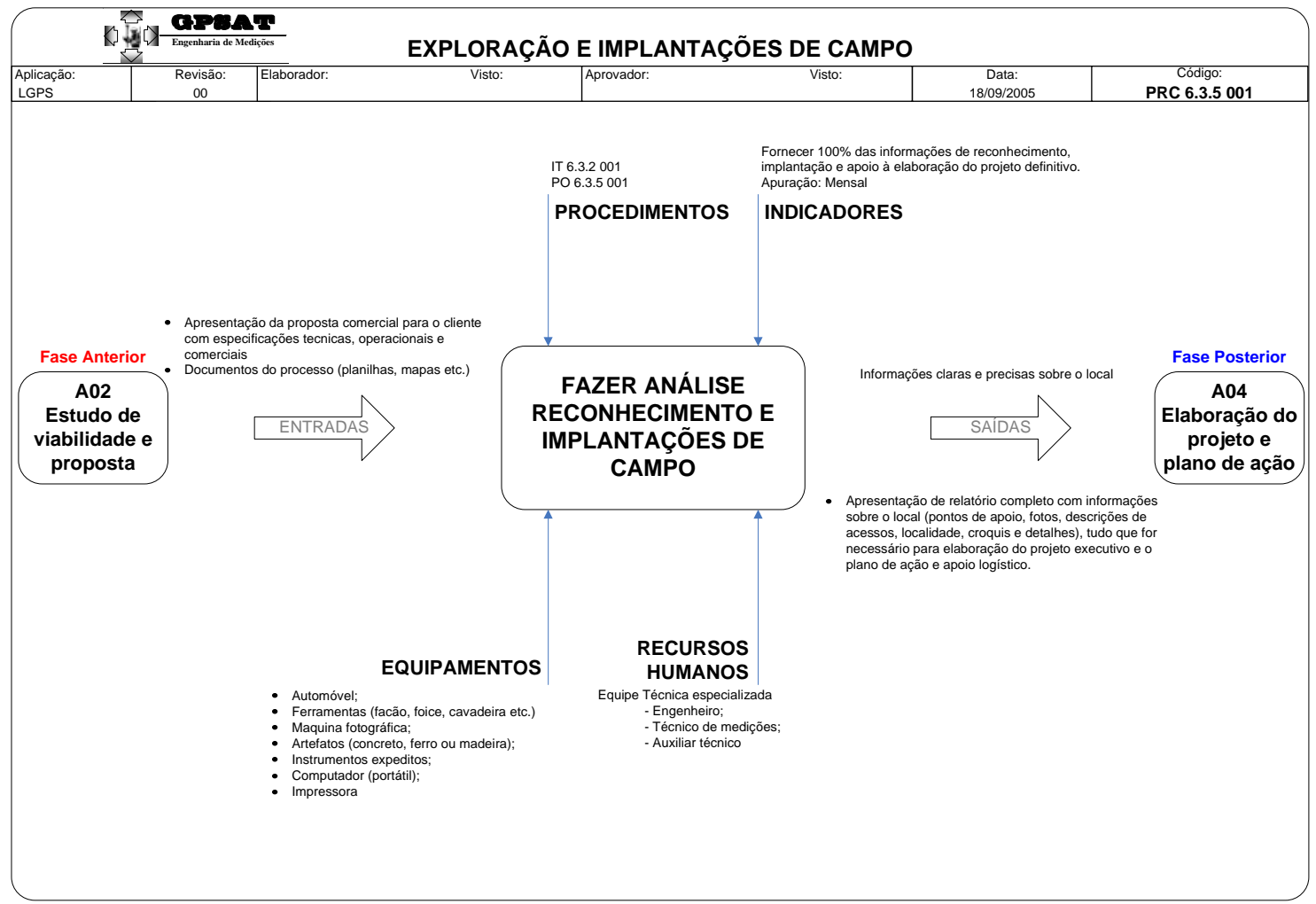

\section{Prc 6.4.1 001: Projeto e planejamento de campo}

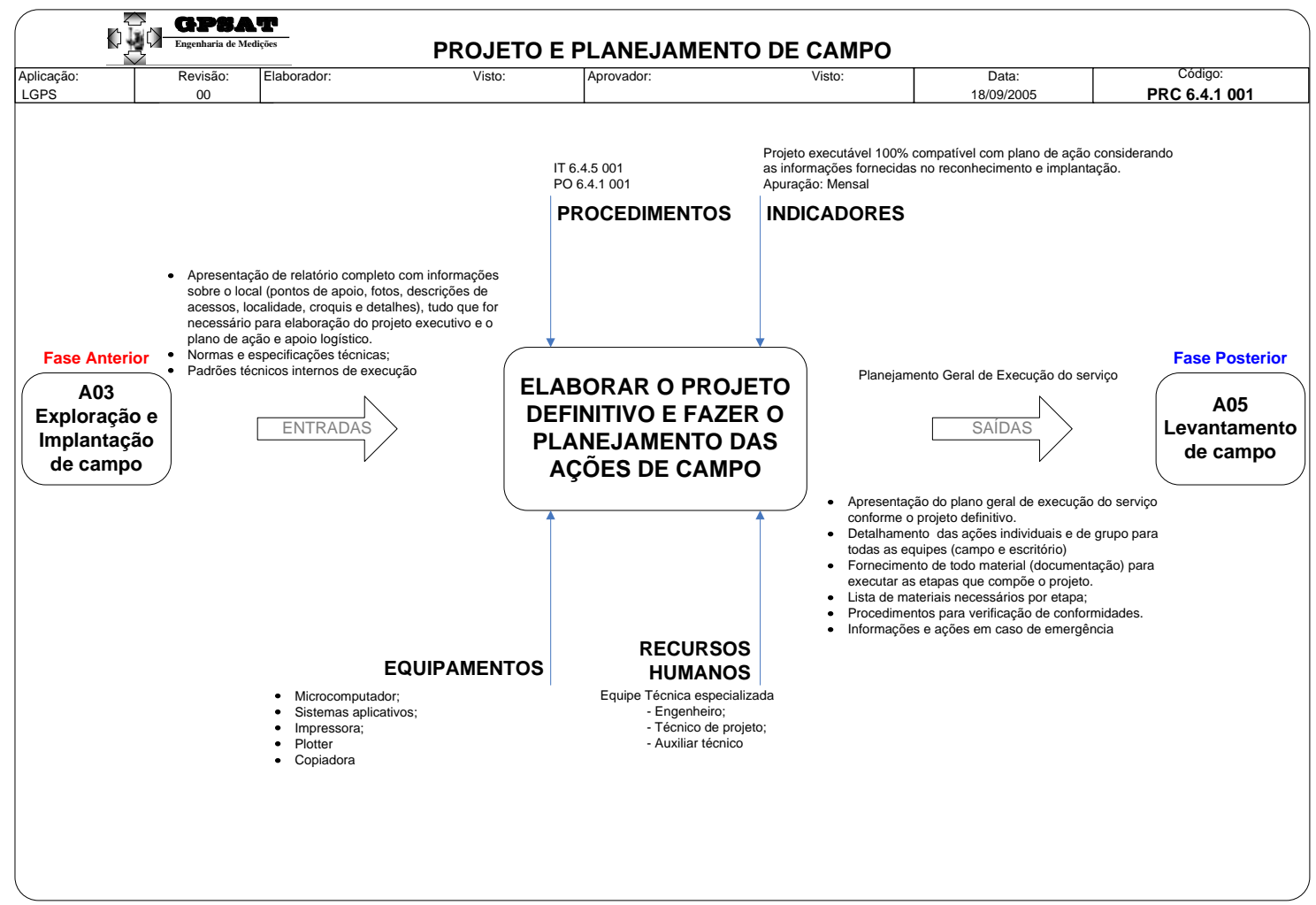


Prc 6.8.1 001: Processamento e refinamento dos dados

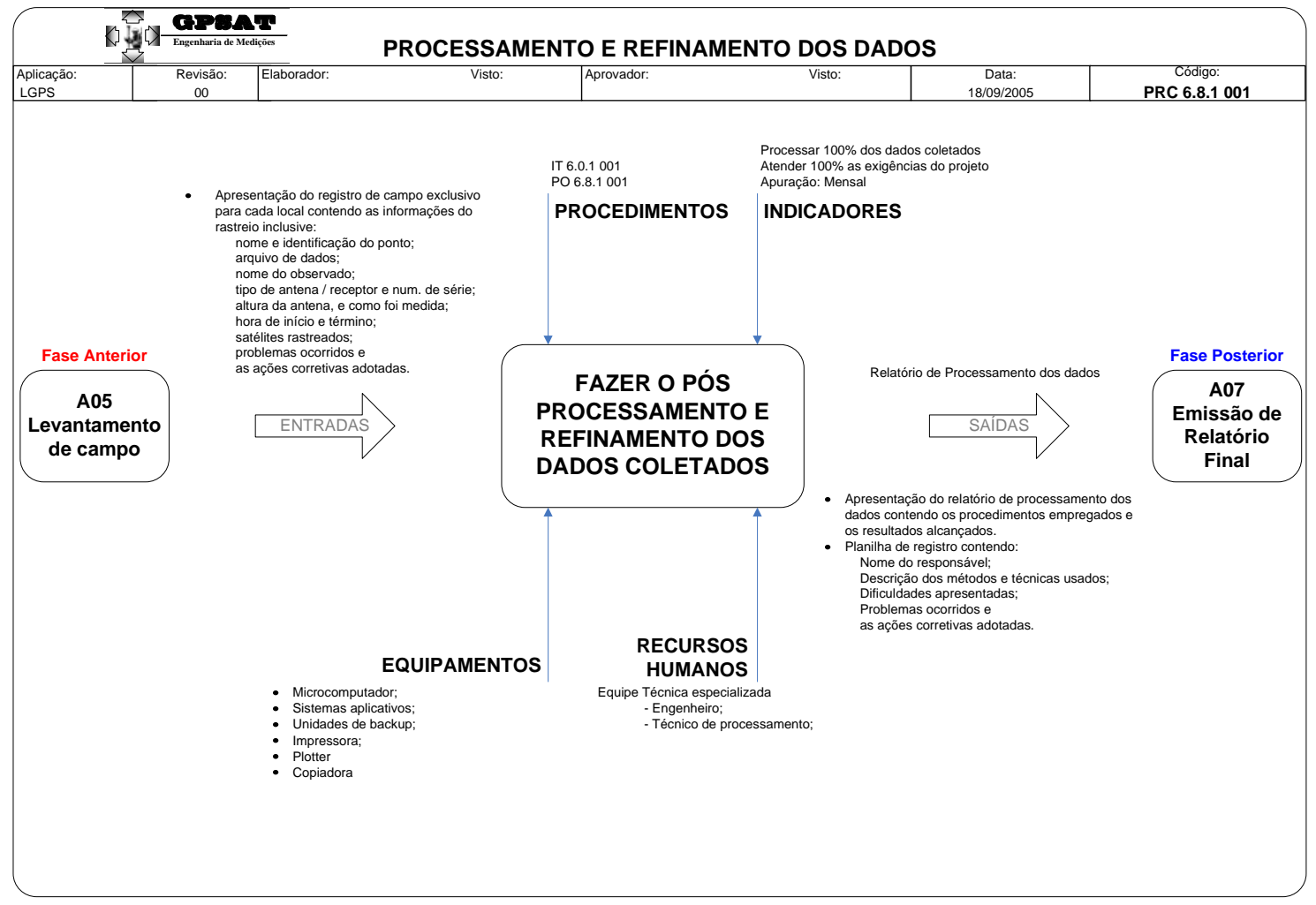

\section{Prc 7.1.1 001: Relatório final de serviço}

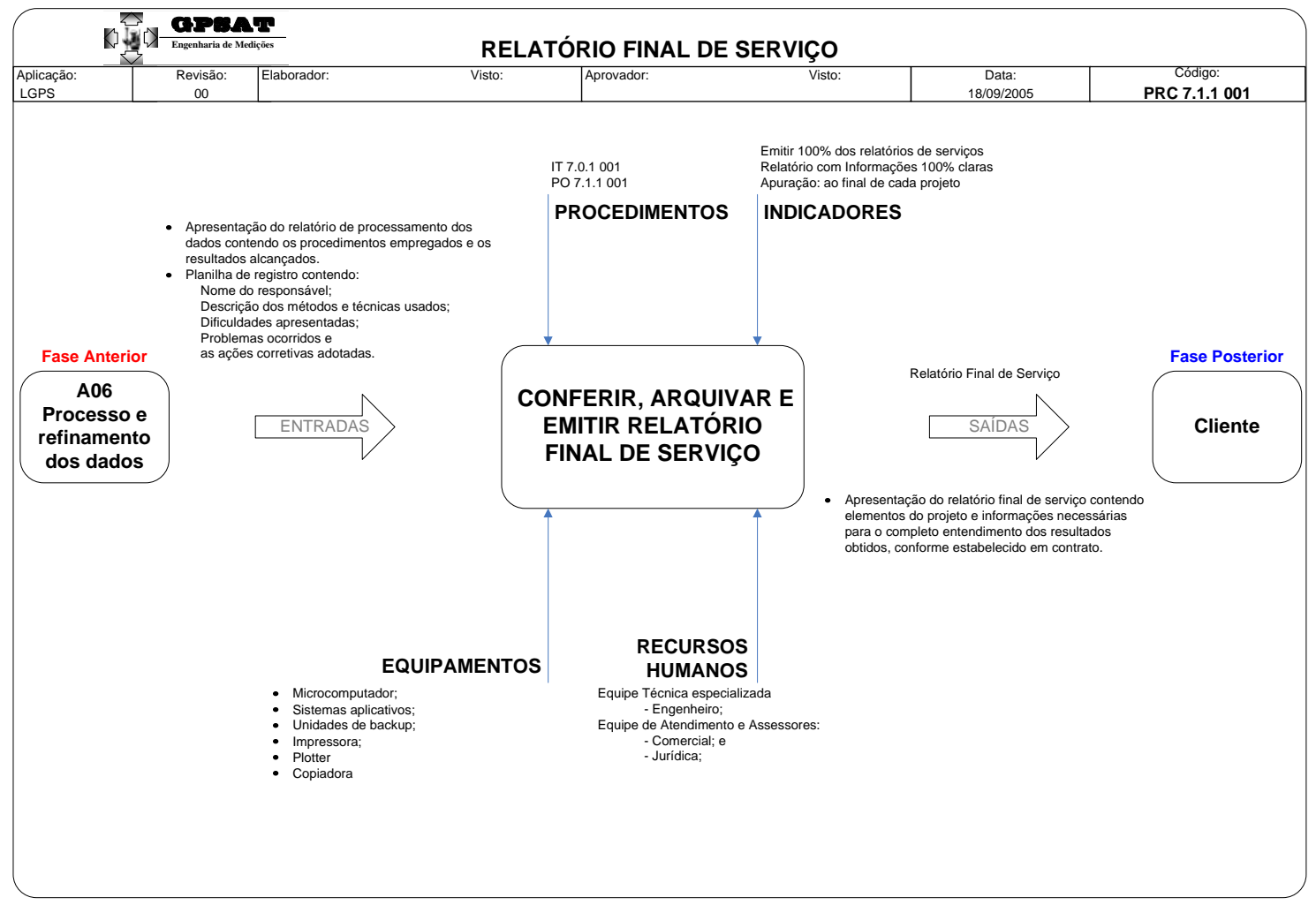


Prc 7.2.2 001: Capacitar pessoal

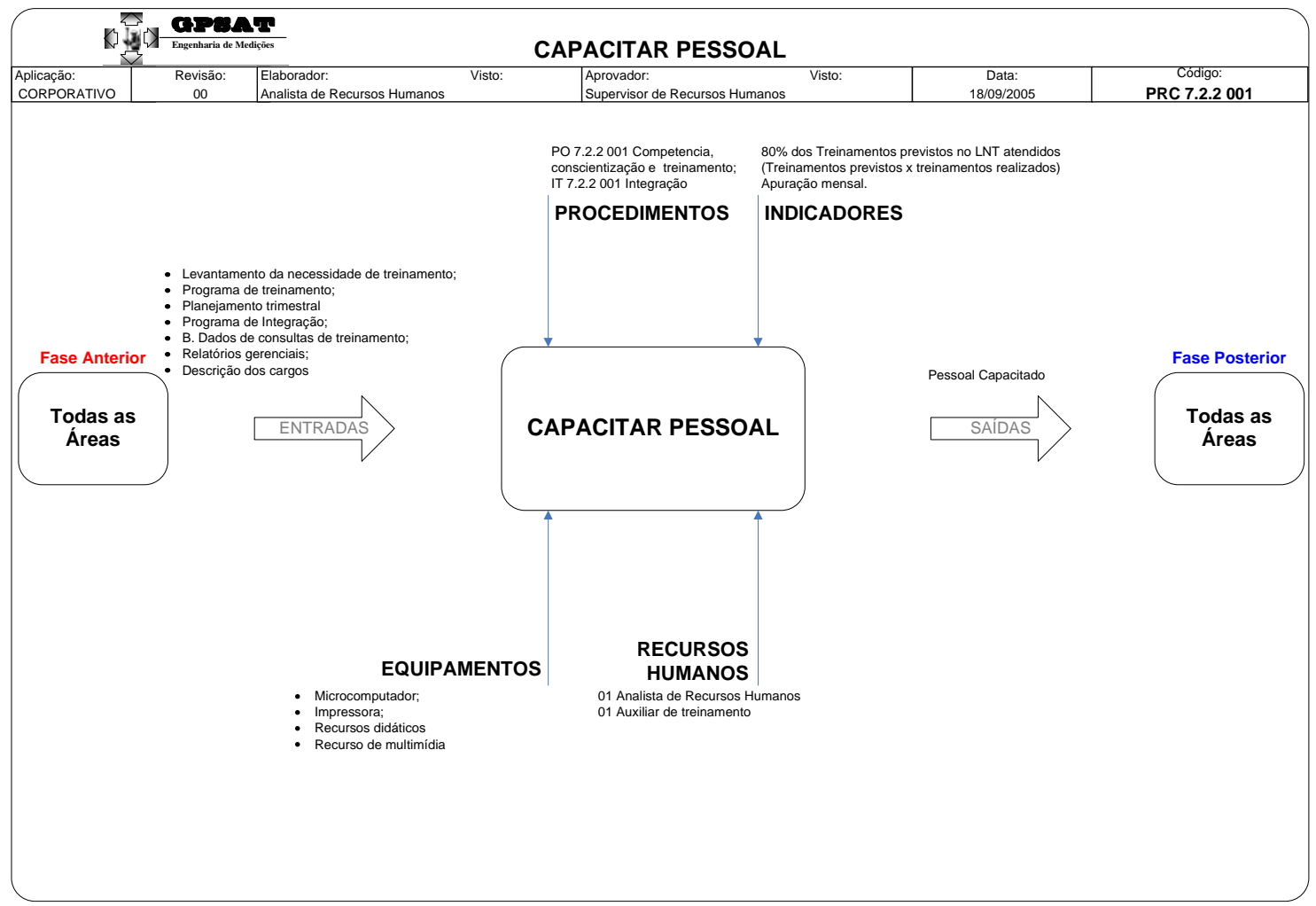




\section{7 - CONCLUSÕES E SUGESTÕES}

As conclusões obtidas com a realização deste trabalho mostram que as suposições consideradas antes do desenvolvimento da pesquisa eram verdadeiras e merecedoras de investigação. A carência e a ausência de informações e material sobre o tema na área de posicionamento com GPS exprimem a realidade do setor.

Os resultados da pesquisa social com empresas de posicionamento com GPS mostraram que na produção dos serviços, os instrumentos são de alta tecnologia (automatização, rapidez e precisão), a mão de obra é altamente qualificada e há um considerado volume de serviços. Porém, como era de se esperar, as formas de gestão ainda se mantêm presas a uma total informalidade e ausência de controle documentado. O grande achado da pesquisa social foi, sem dúvida, o elevado número de empresas que pretendem saber mais sobre um Sistema de Gestão da Qualidade visando implantá-lo em um futuro próximo.

O principal método de Gestão da Qualidade nas empresas de posicionamento com GPS é o informal e, portanto, não foi possível caracterizá-lo, pois não existem registros documentados. Algumas empresas que possuem ou estão implantando um Sistema de Gestão da Qualidade alegaram adotar os conceitos do sistema preconizado pelas normas da série ISO 9000. Porém, não forneceram maiores detalhes quando solicitados.

Na fase de revisão bibliográfica, referente ao tema, foi possível ter noção do grande vazio existente com relação à Gestão da Qualidade nas empresas do ramo, ou melhor, simplesmente não existe material sobre o assunto. Constatou-se que muito se fala em qualidade, porém sempre relacionada a aspectos pontuais e isolados. Mesmo as principais normas e especificações oficiais, tanto nacionais como internacionais, se referem ao assunto apenas com recomendações importantes do mínimo que deve ser feito, deixando à parte o “como” deve ser feito. 
Após analisar historicamente a evolução da qualidade em outros setores, como, por exemplo, a indústria de manufatura, observou-se que tudo é uma questão cultural, que as ações de melhorias são conseqüências das exigências do mercado e do consumidor. Percebeu-se que, embora a globalização tenha proporcionado um aumento da concorrência tanto de produtos como de serviços, ela deu ao consumidor maior poder de escolha e, conseqüentemente, mais conhecimento sobre assuntos restritos até pouco tempo.

O produto resultante de um serviço de posicionamento com GPS, além de ser intangível, não é um produto fim, isto é, ele é “matéria prima” que serve como elemento básico para o desenvolvimento e a concepção de outros produto finais, tais como uma planta, um projeto, um mapa etc. Assim sendo, os clientes desse serviço precisam ter conhecimentos técnicos específicos para poder entender e valorizar a qualidade envolvida no serviço, sob pena de comprometer o futuro de seu produto (financeiro e técnico).

Do ponto de vista de uma empresa ou profissional liberal que presta serviço de posicionamento com GPS, a questão é: como manter os custos baixos e garantir a qualidade dos serviços, sabendo que no mercado há concorrência desleal? A resposta é investir em qualidade, capacitação tecnológica e profissional, pois a tendência futura do mercado é o aumento das exigências, entre elas a certificação, como já acontece com os serviços de georrefenciamento rural para o INCRA.

Após a revisão bibliográfica e a discussão com especialistas da área de qualidade, entende-se que a implantação de um sistema de Gestão da Qualidade, adaptado à situação da empresa ou entidade de posicionamento com GPS, seria um ponto de partida para solução do problema. Após algumas tentativas de parceria sem sucesso, decidiu-se adotar uma empresa genérica (fictícia) com características semelhantes à maioria das empresas do ramo. Para a elaboração do modelo proposto, foi considerada a situação mais desfavorável da empresa, e todos os elementos necessários foram criados ou supostos com base na experiência prática do autor e dos colaboradores.

Ainda como parte da elaboração do modelo proposto, foi feito uma prévia de modelagem dos processos da empresa genérica para facilitar a adequação e atendimento aos requisitos de um sistema de gerenciamento por processos. 
A aplicação dos procedimentos e controles operacionais de um posicionamento com GPS, elaborados a partir do mapeamento e padronização dos processos, foi satisfatória quando aplicados em parte, em um caso real de posicionamento estático de 14 pontos de controle. O planejamento e a seqüência lógica adotada permitiram minimizar os custos produtivos com eliminação principalmente das horas de retrabalho. Os resultados obtidos foram satisfatórios e dentro do limite tolerável de aceitação pelo cliente. A ilustração desse caso mostra que os procedimentos simples de Gestão da Qualidade, adotados no caso, permitiram obter resultados de um produto com qualidade e de baixo custo. Isso certamente fornece à empresa aumento de produção e, conseqüentemente, de lucro.

O modelo proposto para implantação da Gestão da Qualidade segue a tendência atual de enfoque por processos, conforme os principais sistemas de Gestão da Qualidade e tem suas diretrizes adaptadas e adequadas à ISO 9001:2000. Embora se soubesse da importância da aplicação do modelo junto a uma entidade real, isto não foi possível por vários motivos e ajustes de parceria. No entanto, por se tratar de um modelo, esse fato apenas adia sua validação. Espera-se que em breve o modelo possa ser implementado ou ainda servir de referência para alguma organização.

Como sugestões para futuros trabalhos têm-se:

- análise da aplicação e validação desse modelo em uma organização (empresa, setor, departamento) e seus possíveis impactos internos, externos, positivos e negativos;

- ampliação desse modelo ou de um outro para empresas maiores de serviços que tenham diversos ramos da engenharia de posicionamentos e mapeamentos;

- elaboração de um modelo de Gestão da Qualidade para as empresas de geoprocessamento e SIG;

- pesquisa relacionando os custos de implantação de um SGQ no ambiente de uma empresa de posicionamento.

Por fim, conclui-se que o modelo de Gestão da Qualidade proposto é adequado para uma empresa com características semelhantes à empresa genérica considerada e sua adequação ocorrerá a partir do instante em que as etapas forem sendo executadas. Por ser pioneiro na área de posicionamentos com GPS, o assunto amplia os horizontes dos empreendedores e fornece material para consulta e futuras discussões sobre o tema. 


\section{8 - REFERÊNCIAS}

ADAIR, C.B.; MURRAY, B.A. (1996). Revolução total dos processos. São Paulo: Nobel.

ALVARENGA-NETO, C. A. (2004). Proposta de modelo de mapeamento e gestão por macroprocessos. 343p. Tese de Doutorado, Departamento de Engenharia de Produção, EPUSP - Universidade de São Paulo, São Paulo, 2004.

ALVES, C. R. O. (1997) Efeitos decorrentes da Implantação do Sistema da Qualidade e Certificação ISO 9000 em Empresas Brasileiras. 181p. Dissertação (Mestrado) Departamento de Engenharia de Produção, Universidade Federal de São Carlos, São Carlos. 1997.

AMERICAN SOCIETY FOR QUALITY CONTROL (2000). Quality management systems: Fundamentals and vocabulary. Milwaukee.

ASSOCIAÇÃO BRASILEIRA DE NORMAS TÉCNICAS (1994). NBR ISO 8402/1994: Gestão da qualidade e Garantia da Qualidade - Terminologia. Rio de Janeiro.

. (2001a). NBR ISO 9000/2000: Sistema de Gestão da Qualidade - Fundamentos e Vocabulário. Rio de Janeiro.

Rio de Janeiro.

(2001b). NBR ISO 9001/2000: Sistema de Gestão da Qualidade - Requisitos.

. (2001c). NBR ISO 9004/2000: Sistema de Gestão da Qualidade - Diretrizes para melhorias de desempenho. Rio de Janeiro.

. (2002). NBR ISO 19011/2002: Diretrizes para auditorias de sistema de Gestão da Qualidade e/ou ambiental. Rio de Janeiro.

ASSOCIAÇÃO DAS EMPRESAS DE TOPOGRAFIA DO ESTADO DE SÃO PAULO (2001). Programa Setorial de Qualidade - Setor de Topografia. Disponível em: <http://www.cdhu.sp.gov.br/http/qualihab/entidades/cpo/psq_de_topografia.pdf> Acesso em: 28 jul. 2003.

BÁEZ, V.E. et al. (1993) ISO SÉRIE 9000: Auto-avaliação. Rio de Janeiro: Qualitymark.

BARBALHO, S. C. M.; ROZENFELD, H.; AMARAL, D. C. (2002) Análise da Abrangência de Metodologias de Modelagem de Empresas. In: XXVI ENANPAD, 
2002, Salvador. Anais do XXVI Encontro Anual da Associação Nacional dos Programas de Pós-Gradução em Administração.

BARÇANTE, L.C. (1998) Qualidade Total: uma visão brasileira - o impacto estratégico na universidade e na empresa. Rio de Janeiro: Campus.

BEZERRA, C. A. (2001). Projeto de Sistemas de Informação Baseado em Qualidade: Uma Abordagem voltada à Pequena Empresa. 113p. Dissertação (Mestrado) Departamento de Engenharia de Produção e Sistemas, Universidade Federal de Santa Catarina, Florianópolis. 2001.

BRASIL (2000) Leis etc. SECRETARIA ESPECIAL DE DESENVOLVIMENTO URBANO DA PRESIDENCIA DA REPUBLICA. Portaria SEDU/PR $n^{\circ}$ 67, de 21.11.2000. Dispõe sobre o Sistema de Qualificação de Empresas de Serviços e Obras (SIQ). Disponível em: < http://www.mct.gov.br/legis/portarias/67b_2000.htm >. Acesso em: 19 set. 2003.

BRASIL (2001) Leis etc. INSTITUTO NACIONAL DE COLONIZAÇÃO E REFORMA AGRÁRIA. Lei $n^{\circ}$ 10.267, de 28 de agosto de 2001. Dispõe sobre a Criação do Sistema Público de Registro de Terras. Disponível em: <http://www.incra.gov.br/_htm/serveinf/_htm/ legislação/lei/sprt.htm>. Acesso em: 26 ago. 2001.

BRASIL (2004). CONSELHO FEDERAL DE ENGENHARIA ARQUITETURA E AGRONOMIA. Decisão PL 2087/2004, de 03 de novembro de 2004: Profissionais habilitados a desenvolverem atividades definidas pela Lei 10.267. Brasília, DF. Disponível em: < http://legislacao.confea.org.br/mostradec.asp>. Acesso em: 28 jan. 2005.

CAMARGO, P. O. (1999). Modelo regional da ionosfera para uso em posicionamento com receptores GPS de uma frequência. 191p. Tese de Doutorado, Departamento de Geociências - Universidade Federal do Paraná, Curitiba, 1999.

CAMPOS, R.; SANTOS, L. R. (2001) Modelagem de Processos e Definição de Requisitos para Sistemas de Informações para a Previsão de Demanda. In: XXV ENANPAD, 2001, Campinas. Anais do XXV Encontro Anual da Associação Nacional dos Programas de Pós-Gradução em Administração.

CAMPOS, V.F. (1999). TQC - Controle da Qualidade total no estilo japonês. 8.ed.. Belo Horizonte: EDG.

CARRION, C.W. (2001). Situação da Gestão de Qualidade na Construção Civil: Avanços e Desafios. In: SIMPÓSIO DE ENGENHARIA DE PRODUÇÃO, VIII, 2001, Bauru. UNESP/DEP. Disponível em: <http://www.simpep.feb.unesp.br/anais8 /ana8c.html \#GQP>. Acesso em 07 jul. 2003.

CARVALHO, H. A. (2002). Implantação da Gestão da Qualidade em Projetos de Pesquisa e Desenvolvimento em Instituições de Ensino Superior. 167p. Dissertação de Mestrado, Departamento de Tecnologia - Centro Federal de Educação Tecnológica do Paraná, Curitiba, 2002. 
CROSBY, P.B. (1999) Qualidade é investimento. 7ed. Rio de Janeiro: José Olympio, 328p.

DEMING, W. E. (1990) Qualidade: a revolução da administração. Rio de Janeiro: Marques-Saraiva, 367p.

DOMINGUES, M.E.M. (1999) Gestão da Qualidade nos Serviços Hospitalares: Estudo de casos. 189p. Dissertação (Mestrado) - Departamento de Engenharia de Produção, Universidade Federal de São Carlos, São Carlos. 1999.

FABRICIO, M.M.; MARTUCCI, R. (1995). Proposta de um Programa de Gestão da Qualidade Total para Autoconstrução Assistida. In: ENCONTRO NACIONAL DE TECNOLOGIA DO AMBIENTE CONSTRUÍDO, VI, 1995. Rio de Janeiro. Disponível em: <http://www.eesc.sc.usp.br/sap/docentes/fabricio/ENTAC1995_QualAutoConstr.pdf>. Acesso em: 10 jul. 2003.

FAEZARELLA, I. S.; SACOMANO, J. B.; CARPINETTI, L. C. R. (2001). Gestão da Qualidade: Conceitos e Ferramentas. São Carlos. 131p. Publicações EESC, Universidade de São Paulo.

FATOR GIS (2003). Catálogo de Empresas. Curitiba. Disponível em: <http://www.fatorgis.com.br/catalogo.asp>. Acesso em: 05 ago. 2003.

FEDERAL GEODETIC CONTROL COMMITTEE (1988). Geometric geodetic accuracy standards and specifications for using GPS relative positioning techniques (version 5). Rockville.

FEDERAL GEOGRAPHIC DATA COMMITTEE (1998). Geospatial Positioning Accuracy Standards (5 partes). Virginia: Federal Geographic Data Committee.

FEIGENBAUM, A.V. (1994) Controle da Qualidade total: gestão e sistemas, v.1e 2, São Paulo: Makron Books.

FERREIRA, A. B. H. (1999) - Dicionário Aurélio Eletrônico: Século XXI. Versão 3.0. Nova Fronteira \& Lexikon Informática. 1 CD-ROM.

GARVIN, D. A. (1992). Gerenciando a Qualidade: A visão estratégica e competitiva. 2.ed. Rio de Janeiro: Qualitymark.

GERLACK, A.C. (2001) Análise da Gestão da Qualidade na indústria frigorífica da carne bovina do estado de São Paulo. 161p. Dissertação (Mestrado) - Departamento de Engenharia de Produção, Universidade Federal de São Carlos, São Carlos. 2001.

GONÇALVES, J.E.L. (2000) As empresas são grandes coleções de processos. Revista de Administração de Empresas. São Paulo, v.40, n.1, p.6-19,

HOFMANN-WELLENHOF, B., LICHTENEGGER, H. \& COLLINS, J. (2001). GPS: Theory and Practice, 5th ed. Wien New York. Springer Verlag. 
HOUAISS, A. (2001). Dicionário eletrônico Houaiss da língua portuguesa. Versão 1.0. Editora Objetiva. 1 CD-ROM.

INFOGEO (2002). Guia de empresas. Curitiba, n.3. Edição do ano.

INSTITUTO BRASILEIRO DE GEOGRAFIA E ESTATÍSTICA (1983). Resolução $P R$ n. 22. Especificações e normas para levantamentos geodésicos. Boletim de serviço, n.1602.

INSTITUTO BRASILEIRO DE GEOGRAFIA E ESTATÍSTICA (1984). Especificações e normas gerais para levantamentos geodésicos em território brasileiro. Diário Oficial da União.

INSTITUTO BRASILEIRO DE GEOGRAFIA E ESTATÍSTICA (1992). Especificações e normas gerais para levantamentos GPS: Versão preliminar. 23p.

INSTITUTO BRASILEIRO DE GEOGRAFIA E ESTATÍSTICA (1996). Censo Agropecuário de 1995-1996. Disponível em: <http://www1.ibge.gov.br/home/estatistica/economia/agropecuaria/censoagro/brasil>. Acesso em: 10 jul. 2003.

INSTITUTO NACIONAL DE COLONIZAÇÃO E REFORMA AGRÁRIA (2003). Norma Técnica para Georreferenciamento de Imóveis Rurais. 1. ed. Disponível em: <ftp://200.252.80.5/Cartografia/download/Norma\%20T\%E9cnica.pdf >. Acesso em 12 fev. 2004.

INTER-GOVERNMENTAL COMMITTEE ON SURVEYING AND MAPPING (2002). Standards and Practices for Control Surveys (SP1), vers.1.5, pub.n.1. Disponivel em: <http://www.anzlic.org.au/icsm/sp1/sp1.htm>. Acesso em: 16 jun. 2003.

ISHIKAWA, K. (1997) Controle da Qualidade total: à maneira japonesa. 1.ed. Rio de Janeiro: Campus, 321p.

JURAN, J.M. (1992). A Qualidade desde o projeto: novos passos para planejamento da qualidade em produtos e serviços. Traduzido por Nivaldo Montinqueli Jr. São Paulo. Editora Pioneira.

JURAN, J.M., GRYNA, F.M. (1991). Controle da Qualidade handbook: conceitos, políticas e filosofia da Qualidade. São Paulo: Makron, McGraw Hill, 377 p.

KERLINGER, F.N. (1980). Metodologia da Pesquisa em Ciências Sociais: um tratamento conceitual. São Paulo: E.P.U.

KING, L.W. (2004). O código de Hammurabi Escrito aem cerca de 1780 a.C. $1^{\text {aed. São }}$ Paulo: Madras, 77p.

LAS CASAS, A.L. (1999) Qualidade total em serviços: conceitos, exercícios, casos práticos. 3.ed. São Paulo: Atlas. 
LEICA GEOSYSTEMS. (2004). LEICA GPS 1200 Series: Lista de equipamentos. Leica Geosystems, AG, Heerbrugg.

LEICK, A. (1995). GPS Satellite Surveying. 2a Edição. New York. John Wiley \& Sons, Inc.

LEICK, A. (2004). GPS Satellite Surveying. 3a Edição. New York. John Wiley \& Sons, Inc.

LEVINE, D.M.; BERENSON, M.L.; STEPHAN, D. (2000) Estatística: Teoria e aplicações usando microsoft excel em portugues. Rio de Janeiro: LTC.

LUZ, C. (2002). Implantação de Programas da Qualidade pela Certificação ISO 9001 como Diferencial Competitivo para as Organizações. 93p. Dissertação (Mestrado) Departamento de Engenharia de Produção e Sistemas, Universidade Federal de Santa Catarina, Florianópolis. 2002.

MANCUSO, F. L. (1999). Modelagem de Empresas: Integração de Diferentes Métodos através do Formalismo TF-ORM. Revista Eletrônica de Administração - REAd. Porto Alegre, Ed. 11, v.5, n.5, set-out.

MARANHÃO, M. (2001) ISO Série 9000: Manual de implementação. Rio de Janeiro: Qualitymark

MARCONI, M.A.; LAKATOS, E.M. (2003) Fundamentos de metodologia científica. 5.ed. São Paulo: Atlas.

MARQUES, A. P.; ARAUJO NETO, J.O.; SILVA, I. (2004). Situação da gestão da Qualidade em Empresas de Posicionamento com GPS no Brasil In: $6^{\circ}$ CONGRESSO BRASILEIRO DE CADASTRO TÉCNICO MULTIFINALITÁRIO E GESTÃO TERRITORIAL. Florianópolis, SC.

MARQUES, A. P.; SILVA, I. (2003). Proposta Preliminar de um Programa de Gestão da Qualidade Total para uma Empresa de Topografia In: SIMPÓSIO DE ENGENHARIA DE PRODUÇÃO, X, 2003, Bauru. Disponível em: <http://www.simpep.feb.unesp.br/anais10/gestaoqualidprodutividade/arq12.PDF>. Acesso em: 10 fev. 2004.

MARQUES, C. S. A. (1999). Normas NBR ISO 9000 e Qualidade de Pavimentos. 154p. Dissertação (Mestrado) - Escola de Engenharia de São Carlos, Universidade de São Paulo, São Carlos. 1999.

MATTOS, J.C. (1997) Custos da Qualidade como ferramenta de Gestão da Qualidade: conceituação, proposta de implantação e diagnóstico nas empresas com certificação ISO 9000. 130p. Dissertação (Mestrado) - Departamento de Engenharia de Produção, Universidade Federal de São Carlos, São Carlos. 1997.

MEDEIROS, C.B. et al. (2000). Usando questionários virtuais em pesquisas quantitativas. Curitiba. Celepar. Disponível em: <http://celepar7cta.pr.gov.br/ 
Celepar/SiteCel.nsf/0/65d0c8e0fab54aff83256a6200506b3e/\$FILE/VirtualQuest.doc>. Acesso em: 28 jul. 2003.

MELLO, C.H.P. et al. (2002) ISO 9001:2000: Sistema de Gestão da Qualidade para operações de produção e serviços. São Paulo: Atlas.

MERLI, G. (1993). Eurochellenge - The TQM Approach to Capturing Global Markets. Londres, IFS Ltd.

MONICO, J.F.G. (2000) Posicionamento pelo NAVSTAR-GPS: descrição, fundamentos e aplicações. São Paulo. Editora UNESP.

NACIONAL BUREAU DE SERVIÇOS (1997). N-IP-64/Rev. 00/03.97 Sistemas da Qualidade Manual de Curso para Auditores QS 9000. São Paulo.

NATURAL RESOURCES CANADA (1995). GPS Positioning Guide. (3th printing). Ontário. Disponível em: < http://www.geod.nrcan.gc.ca/>. Acesso em: 16 jun. 2003.

OLIVEIRA, M. L. B. (1998). Implantação de Sistema da Qualidade: uma proposta de metodologia para pequenas e médias empresas. Dissertação (Mestrado) Departamento de Engenharia de Produção e Sistemas, Universidade Federal de Santa Catarina, Florianópolis. 1998.

OLIVEIRA, O. J. (2000). Qualidade na Construção Civil: Realidade ou Utopia? In: SIMPÓSIO DE ENGENHARIA DE PRODUÇÃO, VII, 2000, Bauru. Disponível em: http://www.simpep.feb.unesp.br/anais7/ana7c.html\#GQP. Acesso em 07 jul. 2003.

OLIVEIRA, O. J.; MAÑAS, A. V.; MELHADO, S. B. (2002). Gestão da Qualidade em Empresas de Projeto de Edifícios. In: SIMPÓSIO DE ENGENHARIA DE PRODUÇÃO, IX, 2002, Bauru. Disponível em: http://www.simpep.feb.unesp.br/ anais9/ana9c.htm\#GQP. Acesso em: 07 jul. 2003.

PALADINI, E P. (1995) Gestão da Qualidade no Processo: a qualidade na produção de bens e serviços. São Paulo: Editora Atlas.

PARKINSON, B.W. (1997) Origins, Evolution, and Future of Satellite Navigation. Journal of Guidance, Control and Dynamics. Reston, v.20, n.1, p.11-25, jan.- feb.

PARKINSON, B.W. et al. (1995) A History of Satellite Navigation. Navigation: Journal of the Institute of Navigation. Spring, v.42, n.1, p.109-164

PARKINSON, B.W.; SPILKER JR, J.J. (1996) Global Positioning System: Theory and Aplications. v.I (163). Washington. Charles Stark Draper Laboratory, Inc.

REIS, L.F.S.D.; MAÑAS, A.V. (1995) ISO 9000: Implementação e Gerenciamento para a Qualidade Total. São Paulo: Érica.

RICHARDSON, R. J. (1999). Pesquisa social: Métodos e técnicas. 3 ed. São Paulo. Editora Atlas. 
RIZOS, C. (1999). Principles and Practice of GPS Surveying. Sydney. University of New South Wales. Disponivel em: <http://www.gmat.usnsw.edu.au/snap>. Acesso em: 27 fev. 2002.

SANTOS, A. C.; MATOS, P. W.; CARNEIRO, A. C. V. M. (2001). Avaliação da Implantação de um Programa de Qualidade Total em uma Empresa do setor Moveleiro. In: CONGRESSO BRASILEIRO DE ADMINISTRAÇÃO RURAL, IV, 2001, Goiania. Disponível em: http://www.dae.ufla.br/biblioteca/4CongrABAR/GCC2001/gcc405.pdf. Acesso em 18 jul. 2003.

SEEBER, G. (2000). Satellite Geodesy: foundations, methods, and applications. Berlin. Walter de Gruyter, Inc.

SELLTIZ, C. et al. (1987). Métodos de pesquisa nas relações sociais. Edusp. São Paulo.

SILVA, D.C. (2003). Comparação entre a norma do INCRA e normas internacionais de Levantamentos com GPS. In: In: XXI Congresso Brasileiro de Cartografia, 2003, Belo Horizonte. Disponível em: http://www.cartografia.org.br/xxi_cbc/043-G09.pdf. Acesso em 12 jul. 2004.

SIQUEIRA, M.C.M. (2000). Programa de Gestão para a Qualidade Total aplicado a Industria Gráfica. In: SIMPÓSIO DE ENGENHARIA DE PRODUÇÃO, VII, 2000, Bauru. Disponível em: http://www.simpep.feb.unesp.br/anais7/ana7c.html\#GQP. Acesso em 07 jul. 2003.

STARKE, F. (1994). A revolução silenciosa. Revista CNI, ano 27, no. 286, dez-1994. TAGUCHI, G. (1990) Engenharia da Qualidade em Sistemas de Produção. São Paulo: Editora McGraw-Hill.

TEBOUL, J. (1991) Gerenciando a dinâmica da Qualidade. Trad. de Heloísa Martins. Rio de Janeiro: Qualitymark.

THIOLLENT, M. (2002) Metodologia da Pesquisa-Ação. 11.ed. São Paulo: Cortez Editora.

TOLEDO, J.C. (2001) Gestão da Qualidade na Agroindústria. In: BATALHA, M.O. Gestão Agroindustrial. 2 ed. São Carlos: Atlas. v.1, Cap. 8.

TOLEDO, J.C.; MARTINS, R.A. (1998). Proposta de um modelo para elaboração de programas de Gestão para a Qualidade total. Revista de Administração. São Paulo, v.33, n.2, p.52-59.

TOLOVI JR, J. (1994). Porque os Programas de Qualidade Falham? Revista de Administração de Empresas. São Paulo, v.34, n.6, p.6-11.

UNIVERSIDADE DE SÃO PAULO (2002) Diretrizes para elaboração de dissertações e teses na EESC-USP. Escola de Engenharia de São Carlos. Serviço de Biblioteca. 3.ed. São Carlos: SVBIBL. 58p. 
US ARMY CORPS OF ENGINEERS (2003). NAVSTAR GLOBAL POSITIONING SYSTEM SURVEYING: Engineering and Design. Whashington, DC. Disponível em: $<$ http://tycho.usno.navy.mil/gpsinfo.html>. Acesso em 10 fev. 2004.

US NAVAL OBSERVATORY (2004). NAVSTAR GPS Operation. Department of Defense. Disponível em: <http://tycho.usno.navy.mil/gpsinfo.html>. Acesso em 10 fev. 2004.

WELLS, D.E. et al. (1987). Guide to GPS Positioning. 2nd. ed. Fredericton. Canadian GPS Associates. 


\section{9 - GLOSSÁRIOS}

\section{1 - TERMOS DE GPS}

Altura elipsoidal (Ellipsoid Height) - Elevação h de um ponto acima ou abaixo do elipsóide.

Altura Geoidal (Geoid Height) - Elevação N do geóide acima ou abaixo do elipsóide de referência. Também conhecida como ondulação geoidal

Altura Ortométrica (Orthometric Height) - É a elevação H de um ponto acima ou abaixo do geóide. A relação entre as alturas elipsoidal e ortométrica é obtida da seguinte equação: $h=H+N$, onde:

$\mathrm{h}=$ altura elipsoidal

$\mathrm{H}=$ altura ortométrica

$\mathrm{N}$ = altura geoidal ou ondulação geoidal

Ambigüidade (Ambiguity) - Número desconhecido de comprimentos inteiros de onda da portadora entre o satélite e o receptor. Também chamado de ambigüidade de ciclo.

Antispoofing Antispoofing (A/S) - Técnica de criptografia desenvolvida pelo (DoD) Departamento de Defesa dos EUA que quando implementado nega acesso ao código P por qualquer usuário sem autorização.

Atraso da refração ionosférica (Ionospheric Refraction Delay) - Demora na propagação do sinal de GPS causada pela refração do sinal quando atravessa a ionosfera.

Banda L (L-band) - Faixa de freqüência de rádio de 390 MHz até 1550 MHz. O sinal primário da banda L radiado por cada satélite NAVSTAR é L1 em $1575.42 \mathrm{MHz}$ e L2 transmitido em 1227.50 MHz.

Canal (Channel) - Em um receptor de GPS consiste no hardware e no software para localizar o sinal de um satélite em uma das duas freqüências da portadora.

Código C/A (C/A-Code) - Código padrão de aquisição GPS às vezes chamado Clear Access Code, também conhecido como S ou Código Standard. Este código contém uma sucessão de 1023 modulações pseudo-randomicas bifásicas binárias na portadora GPS, com taxa de transmissão de $1.023 \mathrm{MHz}$ e período de $1 \mathrm{~ms}$. 
Código P Precise or Protected Code (P-Code) - Seqüência de modulações bifásicas binárias (pseudo-random) transmitida na portadora de GPS em uma taxa de 10,23 MHz e que se repete a cada 267 dias.

Código Y (Y-code) - O código P depois de criptografado.

Constelação de satélites (Satellite Constellation) - Arranjo físico formado pelo conjunto de satélites no espaço.

Coordenadas Cartesianas/Geocêntricas (Cartesian/Geocentric Coordinates) - Sistema de definição da posição que tem sua origem no centro da terra com os eixos x e y no plano do equador. Tipicamente, o eixo x passa através do meridiano de Greenwich, e o eixo z coincide com o eixo de rotação da terra. Os três eixos são mutuamente ortogonais e formam um sistema destro.

Coordenadas geográficas (Geographic coordinates) - Medida de um local da superfície da terra expressos em graus de latitude e longitude.

Dados de navegação (NAV Data) - Mensagem de NAVegação transmitida por cada satélite em 50bps no sinal L1 e L2. Esta mensagem contém o tempo do sistema, parâmetros de correção do relógio, parâmetros para modelagem do atraso da ionosfera e as efemérides e saúde do satélite. Esta informação é usada no processamento do sinal GPS para obter a posição e a velocidade do usuário. Às vezes chamado de Mensagem de Navegação.

Datum (Datum) - Um sistema de referência horizontal ou vertical para medições e cálculos de posicionamentos. Um conjunto de parâmetros e pontos de controle definem a forma tridimensional da terra com precisão. O datum define parte de um sistema de coordenada geográfica que é a base para um sistema de coordenadas planas. Os datuns horizontais referemse tipicamente a elipsóides e os datuns verticais ao geóide.

Diferenciação (Differencing) - Técnica usada no processamento de linhas base para solucionar o número inteiro de ambigüidade de ciclo e reduzir as várias fontes de erro inclusive variações do oscilador e erros de modelagem atmosféricos e orbitais. Esta técnica faz diferenças na medida de batimento da fase da portadora através do tempo, freqüência, receptores, satélites, ou qualquer combinação destes. As diferenças mais populares são descritas abaixo:

Simples diferença entre receptores é a diferença instantânea na medida completa de batimento da fase da portadora feita em dois receptores que observam o mesmo sinal simultaneamente.

Dupla diferença entre receptores e entre satélites é encontrada diferenciando a simples diferença para um satélite com a simples diferença para outro satélite, onde ambas as simples diferenças são da mesma época.

Tripla diferença entre receptores, entre satélites e entre épocas (tempo) é a diferença entre uma dupla diferença em uma época e a mesma dupla diferença na época seguinte.

Diluição da precisão Dilution of Precision (DOP) - Medida da contribuição geométrica para a incerteza de uma posição fixa. As definições mais populares são:

GDOP - Geometric Dilution of Precision - precisão da medida em posição tridimensional e tempo.

PDOP - Position Dilution of Precision - precisão da medida em posição tridimensional HDOP - Horizontal Dilution of Precision - precisão da medida em posição horizontal bidimensional.

VDOP - Vertical Dilution of Precision - precisão da medida como desvio-padrão da altura vertical.

RDOP - Relative Dilution of Precision - medida da qualidade das reduções da linha base. 
Disponibilidade seletiva Selective Availability (S/A) - Política do DoD para degradar intencionalmente a precisão alcançável do GPS para usuários civis.

Efeméride transmitida (Broadcast Ephemeris) - São as efemérides transmitidas pelos satélites GPS.

Efemérides (Ephemeris) - Uma declaração tabular das posições de um corpo celestial (satélite) em intervalos regulares.

Efemérides precisas (Precise Ephemeris) - São as efemérides calculadas depois da transmissão do sinal do satélite e baseada nas informações de localização do satélite.

Elipsóide (Ellipsoid) - Forma geométrica formada pela revolução de uma elipse sobre seu eixo secundário. Um elipsóide é definido pelo comprimento de seu semi-eixo principal a e seu achatamento $\mathrm{f}$ onde: $\mathrm{f}=(\mathrm{a}-\mathrm{b}) / \mathrm{a}$;

$\mathrm{b}=$ comprimento do semi-eixo menor.

Desde janeiro de 1987, o GPS é referenciado ao elipsóide WGS 84.

Época (Epoch) - Um período de tempo ou uma data selecionada como um ponto de referência.

Fase da portadora (Carrier Phase) - Medida de fase da onda da portadora. O valor em porcentagem normalmente é convertido em milímetros.

Freqüência fundamental (Fundamental Frequency) - A freqüência fundamental do GPS "fo" é 10,23 MHz. As freqüências das portadoras são: $\quad \mathrm{L} 1=154 \mathrm{x}$ fo $=1575,42 \mathrm{MHz}$ e

$$
\mathrm{L} 2=120 \mathrm{x} \text { fo }=1227,60 \mathrm{MHz}
$$

Geoide (Geoid) - Superfície equipotencial que se aproxima da superfície da terra e corresponde ao nível médio do mar nos oceanos e se estende pelos continentes. Em outras palavras, o geoide coincide com a superfície na qual os oceanos formariam em cima da terra inteira se fossem livre quando ajustados ao efeito combinado da atração de massa da terra e a força centrífuga da rotação da terra.

GPS (GPS) - Sistema de Posicionamento Global Global Positioning System. O GPS consiste nos satélites NAVSTAR distribuídos em seis planos orbitais diferentes, cinco estações de monitoramento, e a comunidade de usuários.

\section{Ionosfera (Ionosphere)}

Região da atmosfera da terra entre a estratosfera e a exosfera que fica aproximadamente de 80 a 400 quilômetros sobre a superfície da terra.

Posicionamento cinemático Stop and Go (Stop-and-Go Kinematic Surveying) - Técnica diferencial de posicionamento com GPS por meio da qual um receptor de GPS permanece fixo em um ponto de controle conhecido, enquanto um outro receptor remoto, coleta dados em um ponto de posição desconhecida durante um curto período de tempo, normalmente segundos, e então é movido a outros pontos subseqüentes para coletar dados. Durante todo o tempo de observação os receptores devem rastrear sinais de quatro ou mais satélites continuamente.

Linha de base (Baseline) - Vetor resultante tridimensional V entre duas estações em que foram coletados e processados os dados simultâneos de GPS. Geralmente são determinados em coordenadas Cartesianas do centro terrestre, onde: $\mathrm{V}(\Delta \mathrm{x}, \Delta \mathrm{y}, \Delta \mathrm{z})$.

Linha de base independente (Independent Baseline) - Linhas base que provêem uma única solução de posição para uma determinada estação. 
Medições simultâneas (Simultaneous Measurements) - Medida ou conjunto de medidas efetuadas na mesma época.

Mensagem do satélite (Satellite Message) - É também conhecido como os dados do código (D). É um fluxo de dados de baixa-freqüiência (50 Hz) transmitido em ambas as portadoras (L1 e L2) do sinal dos satélites. O fluxo de dados é projetado para informar o usuário sobre a saúde e a posição do satélite. A mensagem do satélite pode ser decodificada pelo receptor e usada para posicionamento em Tempo Real.

Multicaminhamento (Multipath) - Desvio no caminho percorrido pelo sinal entre o satélite e o receptor. Fenômeno semelhante aos "fantasmas" em uma tela de televisão. Os sinais emitidos pelos satélites de GPS que chegam a uma antena percorrem caminhos diferentes. O sinal que percorreu um caminho mais longo pode ter sido refletido por um ou mais objetos, por exemplo o chão, um veículo, uma construção ou qualquer outra superfície. Uma vez recebido pela antena, este fornecerá uma estimativa da pseudodistância maior e aumentará o erro.

NAVSTAR (NAVSTAR) - É o nome dado a constelação de satélites de GPS, originalmente fabricados pela Rockwell Internacional.

Perda de ciclo (Cycle Slip) - Uma descontinuidade na medida de batimento da fase da portadora que resulta em uma perda temporária de contato do rastreio da portadora em um receptor de GPS.

Pontos de controle (Control Points) - Pontos para os quais foram atribuídas coordenadas. Estas coordenadas foram seguramente fixadas e podem ser usadas em outros posicionamentos dependentes.

Portadora (Carrier) - Onda de rádio de alta-freqüência que tem pelo menos uma característica (freqüência, amplitude, ou fase) que pode ser variada pela modulação de um valor aceitável. Em geral, o comprimento de onda da portadora é muito mais curto que o comprimento de onda dos códigos.

Posicionamento (Positioning) - Determinação de uma posição (normalmente da antena do GPS) com relação a um sistema de coordenada (WGS 84, UTM, plano local, etc.).

Posicionamento absoluto (Absolute Positioning) - Método que usa apenas um receptor de GPS para determinar sua posição (sem receptor de referência).

Posicionamento Cinemático (Kinematic Positioning) - Descreve freqüentemente o posicionamento dinâmico. É uma técnica de posicionamento diferencial GPS, na qual um receptor de GPS fica fixo em um ponto de controle conhecido, enquanto um outro receptor de GPS em movimento coleta os dados rastreados de quatro ou mais satélites continuamente durante o período de observação.

Posicionamento Estático (Static Positioning) - Determinação da posição de um receptor estacionário.

Posicionamento relativo (Relative Positioning) - Determinação da posição de uma estação relativa a uma estação de referência quando os receptores em cada estação estão simultaneamente rastreando os mesmos sinais.

Pseudodistância (Pseudorange) - Tempo necessário em um alinhamento para replicar o código de GPS gerado no receptor com o código recebido do satélite. (representa a distância percorrida na velocidade da luz). A variação do tempo é tomada como a diferença entre o sinal recebido e o transmitido, onde a recepção é medida na referência de tempo do receptor e a transmissão na 
referência de tempo do satélite. Então, a pseudodistância contém vários erros inclusive sincronismo do relógio satélite/receptor e erro de efemérides do satélite.

Seção de observação (Observing Session) - Período de tempo no qual são coletados os dados.

Segmento de controle (Control Segment) - Uma rede mundial de estações de controle do GPS que monitoram e asseguram a precisão das órbitas e as operações dos relógios atômicos dos satélites GPS. O segmento de controle original consiste nas instalações das bases de Diego Garcia, Ilha de Ascensão, Kwajalein, Havaí, e uma estação máster de controle no Consolidated Space Operations Center (CSPOC) em Colorado Springs, Colorado.

Segmento do usuário (User Segment) - Parte do sistema GPS que corresponde aos principais componentes que podem ser conectados diretamente pelo usuário (ex. receptores de GPS).

Segmento Espacial (Space Segment) - Parte do sistema GPS que corresponde aos componentes espaciais (por ex. os satélites GPS).

Troposfera (Troposphere) - Camada interna da atmosfera, situada entre 9 e $20 \mathrm{~km}$ acima da superfície da terra.

UERE User Equivalent Range Error (UERE) - Termo para medição precisa com GPS que representa os efeitos combinados da incerteza das efemérides, propagação de erros, erros do relógio e sincronismo, e ruído do receptor. Um UERE alto pode indicar que o S/A foi imposto no satélite usado. 


\section{2 - TERMOS DE QUALIDADE}

Abordagem holística - Entendimento e prática do relacionamento causa-e-efeito (ou meios e fins). Foi originalmente proposta por Maslow, em 1954.

Ação Corretiva - Ação implementada para eliminar as causas de uma não-conformidade, de um defeito ou de outra situação indesejável existente, a fim de prevenir sua repetição.

Ação de melhoria - V. Ação corretiva.

Ação Preventiva - Ação tomada no sentido de impossibilitar ou ao menos dificultar a recorrência de um problema devido à mesma causa. Pode ser referido a alteração de um projeto ou processo, revisão de um contrato, especificação, elemento ou item do Sistema da Qualidade ou do próprio Sistema da Qualidade.

Acurácia - V. Exatidão.

Adequação ao uso - Conceito simplificado da qualidade que tem por base a existência de características e desempenho de um material, item, produto ou serviço necessário e suficiente para o fim a que se destina.

Adequação ao padrão - Condição existente em um fabricante, laboratório ou estação de medição quando padrões corretamente aferidos e de exatidão adequada estão disponíveis para dar suporte a todas as medições de características necessárias/exigidas em especificações.

Administração orientada para o processo - Estilo de administração com ênfase em melhoria de processos, em conjunto com os resultados deles obtidos. Propicia resultados mais consistentes, previsíveis e duradouros no médio e longo prazo.

Administração orientada para resultados - Estilo de administração cuja ênfase está no atingimento e controle dos resultados em curto prazo, não se importando com a forma (processo) como são obtidos e, em conseqüência, sem preocupação quanto à melhoria do processo.

Administração por fatos - Administração de cada fase do trabalho através de dados objetivos (fatos) ao invés de opiniões e tomada de decisões baseadas nestas informações.

Alta Administração - Conjunto dos responsáveis ao mais alto nível de hierarquia de uma organização (presidente, diretor geral, diretores).

Ambiente Organizacional - Clima em uma organização, resultante da forma como a alta administração lida com seus funcionários.

Ambiente Tecnológico - Forças externas e internas que desenvolvem novas tecnologias, gerando novos produtos e serviços, e novas oportunidades e ameaças de mercado.

Amostra representativa - Amostra escolhida ou retirada através de um método que minimize a existência de tendências entre a amostra e o lote ou população. 
Amostragem probabilística - Amostragem na qual todos os elementos da produção original têm probabilidade conhecida (e diferente de zero) de pertencer à amostra.

Amostragem representativa - Processos através do qual amostras são retiradas de lotes, processos ou populações de forma que exista a menor diferença possível entre os valores das características das amostras e os valores reais correspondentes aos lotes, processos ou populações.

Análise crítica - Avaliação dos requisitos de um Sistema da Qualidade, projeto, processo, produto, serviço ou informação com o objetivo de identificar problemas ou não conformidades e a subseqüente proposição de ações corretivas.

Análise de defeitos ou não conformidades - Análise relativa a materiais, itens, unidades de produto ou serviços defeituosos ou não conformes com o objetivo e identificar e providenciar ações corretivas e preventivas pertinentes. As principais ferramentas utilizadas são correlação, diagrama de dispersão, diagrama de Ishikawa, diagrama de Pareto, distribuição de freqüências, gráficos de controle, gráficos de tendências, histograma e regressão.

Análise do modo e efeitos da falha (FMEA) - Técnica utilizada para avaliar um projeto (processo, produto ou serviço) quanto aos possíveis modos em que uma falha, defeito ou pane pode ocorrer, identificando inicialmente as falhas em potencial e estudando a seguir o seu efeito no sistema total e definindo as ações preventivas em ordem de prioridade.

Anteprojeto - Conjunto de procedimentos que buscam organizar e apresentar, dentro de uma escala de valores, os antecedentes suficientes para justificar o mérito técnico-econômico de uma iniciativa de dotação de recursos (humanos, materiais e financeiros), porem sem os detalhes exigidos para uma decisão final.

Arquivo de controle - Local apropriado para armazenar registros de atividades e sistemas de controle da qualidade.

ASQC - American Society for Quality Control - Entidade norte-americana que congrega profissionais interessados na engenharia da qualidade e na Gestão da Qualidade. Oferece diversas certificações profissionais, entre as quais a mais importante e conhecida é a de engenheiro da qualidade (Certified Quality Engineer - CQE). No Brasil, os exames para certificação são aplicados pela Associação Brasileira de Controle da Qualidade - ABCQ.

Auditoria da qualidade - Exame sistemático e independente, para determinar se as atividades da qualidade e seus resultados estão de acordo com as disposições planejadas, se estas foram implementadas com eficácia e se são adequadas à consecução dos objetivos.

Banco de Dados BD - Arquivo de assuntos inter-relacionados utilizados com o objetivo de coleta de dados de maneira rápida e racional, normalmente através de equipamentos eletrônicos de processamento.

Benchmarking - Processo sistemático e contínuo de avaliação de estratégias, operações, processos, metodologias de trabalho, produtos e serviços de organizações que efetivamente pratiquem e sejam reconhecidas como melhores de uma determinada classe e como exemplos organizacionais. Trata-se, portanto, de padrões das melhores praticas de mercado.

Brainstorming - Técnica utilizada por grupos de trabalho ou times da qualidade para encorajar a geração, esclarecimento e avaliação de uma lista de idéias, problemas ou tópicos, de forma criativa e rápida, a respeito de um determinado assunto. A ênfase é na quantidade de idéias e não na qualidade. 
Capacitação de pessoal - Procedimento que visa educar e treinar funcionários para o exercício de determinadas funções.

Certificação - Ato ou efeito de atestar por escrito a qualificação técnica de uma organização ou de um profissional.

Certificação da ISO - Declaração emitida por um organismo de certificação credenciado, que atesta que a organização solicitante cumpre com os requisitos das normas ISO série 9000 . Tratase de uma prova publica. Para ser certificada, a organização precisa comprovar que tem um Sistema da Qualidade implantado e em funcionamento.

Ciclo PDCA - Mais conhecido dos ciclos de controle de processos, trata do planejamento (PLAN) da atividade ou tarefa, da sua execução (DO), da comparação dos resultados com os padrões previamente estabelecidos (CHECK) e da implementação (ACT) de ações de melhoria (ou ações corretivas), sempre que forem observados desvios.

Cinco S (cinco sensos) - Filosofia japonesa que enfatiza o conceito de manter em ordem o local de trabalho, propiciando eficiência, melhores condições de trabalho e a eliminação de desperdícios, e, por conseqüência, maior segurança, qualidade e produtividade. (Seiri: senso de utilização; Seiton: senso de ordenação; Seiso: senso de limpeza; Seiketsu: senso de higiene e asseio e Shitsuke: senso de disciplina).

Cliente - Em termos amplos, é a organização ou pessoa a quem é fornecido um produto, serviço ou informação, ou ainda, que seja afetada por um produto, serviço ou processo. O principal cliente de um determinado funcionário pode ser a pessoa da mesa ao lado ou do posto de trabalho seguinte, sendo, nesse caso, denominado cliente interno.

Confiabilidade - Habilidade de um sistema, instalação, equipamento, dispositivo, produto ou serviço desempenhar suas funções satisfatoriamente, de acordo com determinadas especificações, num dado intervalo de tempo, sob condições preestabelecidas. Quantitativamente, confiabilidade é a probabilidade de sucesso. Tem como subcaracterísticas: maturidade, tolerância à falhas e recuperabilidade.

Conformação - Medida da fidelidade com que um item, produto ou serviço cumpre com os requisitos de especificação, contrato ou regulamento, ou com os requisitos de aceitação, de acordo com o projeto.

Conscientização para qualidade - Ação destinada a fornecer a todos os funcionários, em todos os níveis hierárquicos, os conhecimentos dos princípios, formas de aplicação e objetivos da qualidade, e convencê-los da vaidade, da necessidade e das suas vantagens.

Controle da qualidade CQ - Técnicas operacionais e atividades utilizadas para atender aos requisitos da qualidade em estágios relevantes do ciclo da qualidade (espiral da qualidade), objetivando a monitoração de processos, a eliminação de desempenho insatisfatório, a satisfação de clientes e a conseqüente eficácia econômica.

Controle da qualidade de processo - Parte do controle da qualidade que trata da manutenção da variabilidade do processo dentro de limites requeridos.

Controle da qualidade total TQC - Sistema voltado para propiciar satisfação ao cliente, gerando produtos e serviços de forma organizada e econômica, com assistência ao cliente/consumidor, estruturado de forma a que todos os funcionários da organização possam participar, contribuir e estar comprometidos com os esforços de desenvolvimento, manutenção e melhoria da qualidade de forma global. 
Controle de Processo - Avaliação sistêmica do desempenho de um processo, a tomada de ações corretivas quando o desempenho não estiver em conformidade com as normas ou especificações, e a tomada de ações preventivas (quando aplicáveis) para garantir ou evitar a reocorrência das mesmas causas.

Cultura organizacional - Conjunto próprio e específico de valores, crenças, hábitos, estilos e memória coletiva que permeiam uma determinada organização.

Custos da má qualidade CMQ - Custo decorrente de defeitos, não conformidades, erros e deficiências em sistemas, processos, produtos e serviços.

Custos de não-conformidade - Custos decorrentes do não-atendimento aos requisitos do cliente, de retrabalhos ou de correção de defeitos ou não-conformidades.

Custos da Qualidade CDQ - Quantia em dinheiro despendido para a obtenção de produtos e /ou serviços com determinado nível de qualidade. Corresponde ao somatório dos custos de prevenção de falhas, erros, defeitos e não conformidades, avaliação da qualidade, falhas internas e falhas externas. Os custos da qualidade representam um percentual normalmente elevado em relação ao faturamento de uma empresa. Esse percentual varia muito de empresa para empresa, principalmente em função de seu ramo d atividade. Normalmente situa-se entre $5 \%$ a $25 \%$ de seu faturamento.

Desdobramento da função qualidade QFD - Subdivisão de metas da qualidade de uma organização e alocação de submetas em níveis hierárquicos mais baixos. É um método estruturado no qual os requisitos dos clientes (necessidades e expectativas) conhecidos como as "verdadeiras características da qualidade" são traduzidos em requisitos técnicos apropriados para cada estágio do desenvolvimento do produto ou serviço, produção e prestação do serviço.

Desempenho - Resultado de realizações de funções especificadas por um item, produto, serviço, sistema, instalação, organização ou pessoa.

Desenvolvimento de recursos humanos - Conjunto de atividades que tem por objetivo dar condições aos indivíduos de exercer determinadas funções com competência, através de conhecimentos e habilidades obtidos por treinamento e experiência profissional.

Diagnóstico - Processo de estudo dos sintomas de um problema ou de uma situação, análise dos dados relevantes e identificação das causas do problema ou situação de deficiências de qualidade.

Diagrama de ISHIKAWA (espinha de peixe) - Técnica visual que interliga os resultados (efeitos) com os fatores (causas), propiciando uma visualização prática das variáveis (causasraízes) que afetam um processo analisado ou um problema, sendo uma das mais importantes ferramentas do ciclo de melhoria da qualidade de processos e uma das sete ferramentas do controle da qualidade.

Documento da qualidade - Qualquer informação registrada de forma escrita e/ou através de desenho que descreva, defina, especifique, homologue ou certifique atividades, requisitos, características ou resultados de características da qualidade de um material, item, produto ou serviço.

Eficácia - Medida do hiato que pode existir entre os resultados obtidos e as metas ou objetivos da qualidade especificados. Relaciona-se com o fazer as coisas certas, com o que deve ser feito, com o resultado do que se fez. 
Eficiência - Relação entre os recursos humanos, as maquinas e o capital investido e os resultados advindos do uso desses recursos, ou seja, é o grau de aproveitamento dos recursos utilizados para produzir bens e serviços.

Empowerment - Termo que tem o significado de dar autonomia e poder a quem antes não tinha.

Empresa - Parte interessada num negócio de fabricação, produção, fornecimento ou aquisição de produto, prestação ou compra de serviço. Apresenta fatores de produção materiais e imateriais reunidos sob a autoridade de um indivíduo ou de um grupo para atrair, por meio da produção de bens e serviços, uma clientela e daí obter rendimento monetário.

Enfoque sistêmico - Conjunto de tipos de abordagens utilizadas para enfocar um sistema.

Entidade - Denominação atribuída a uma organização que estabelece normas contratuais que podem ser utilizadas entre clientes e fornecedores. Essas normas podem referir-se a materiais, itens, produtos, serviços, organização ou Sistema da Qualidade.

Equipe - Pequeno grupo cooperativo, motivado por uma tarefa comum, solidário, caracterizado pela unidade, coesão e espírito de equipe.

Especificação - Documento que se destina a fixar as características de matérias-primas, insumos, produtos intermediários, produtos acabados, serviços, processos, componentes, equipamentos, materiais etc., bem como as condições para sua aceitação ou rejeição; preferencialmente de forma numérica em termos de unidades apropriadas.

Especificação técnica - Documento que especifica através dos dados técnicos mínimos requeridos, produtos e ou serviços, elementos ou conjuntos específicos para os quais não é necessário a elaboração de uma norma.

Estrutura Organizacional - Regulamentos, responsabilidades e autoridades através dos quais uma organização realiza suas funções.

Exatidão - Proximidade entre um valor observado e o valor aceito como referência.

Expectativa de clientes - Tudo de que os clientes gostariam de receber, o que pensam que pode ser fornecido por ou obtido de uma organização, a um preço com o qual concordam em pagar e no prazo que satisfaça seus interesses.

Ferramentas da qualidade - Expressão de uso geral utilizada para designar as ferramentas estatísticas (gráficos de controle, de dispersão, de Pareto de tendências, histogramas etc.) e as técnicas especificamente aplicadas a qualidade (ciclo PDCA, controle estatístico de processo, análise do modo e efeitos de falha FMEA etc.).

Folha de processo - Documento que estabelece a seqüência de operações a serem realizadas para a produção ou fabricação de um material.

Fornecedor Externo - Pessoa ou organização que fabrica ou agrega valor a um produto ou presta serviço a uma outra organização.

Fornecedor Interno - Pessoa ou setor da organização que produz ou agrega valor a um produto ou presta serviço a uma pessoa ou setor de uma mesma organização. 
Garantia da Qualidade - Conjunto de atividades planejadas e sistemáticas, implementadas no Sistema da Qualidade e demonstradas como necessárias para prover confiança adequada de que uma entidade atenderá os requisitos para a qualidade.

Gestão da Qualidade - Todas as atividades da função gerencial que determinam a política da qualidade, os objetivos e as responsabilidades, e os implementam por meios tais como: o planejamento da qualidade, o controle da qualidade, a Garantia da Qualidade e a melhoria da qualidade dentro do Sistema da Qualidade.

Gestão da qualidade total - Processo sistemático de melhoria da satisfação de clientes externos e internos, através do uso de gerenciamento e cultura que incorporem princípios de melhoria contínua da qualidade por toda a organização, baseado no envolvimento de todos os seus membros e visando ao sucesso e beneficio de longo prazo de todos os membros da organização e da sociedade.

Guia da qualidade - Documento contendo explanações, interpretações, sugestões e fatores a serem considerados como pratica padrão ou melhores práticas.

Gurus da qualidade - Expressão usada para designar pessoas reconhecidas mundialmente por seu trabalho de desenvolvimento de teorias, métodos e técnicas em qualidade, especialmente nos Estados Unidos e no Japão.

Implementação da qualidade - Processo que transforma o conjunto de planos, programas e estratégias de qualidade em ações, de forma a atingir os objetivos e metas da qualidade.

Inspeção - Comparação de qualquer característica da qualidade de um material, item, instrumento, processo ou unidade de produto ou serviço com uma especificação.

Instituição - V. Empresa; Entidade; Estrutura Organizacional; Organização.

Instrução de trabalho - Documento normativo que se destina a descrever a maneira correta de executar uma operação e/ou tarefa, de modo simples e direto. Deve ser preferencialmente elaborado com base em normas.

ISO International Organization for Standardization - Organização internacional para normalização.

ISO 9000 - Série de normas internacionais que tratam da gestão e Garantia da Qualidade que têm sido adotadas em muitos paises e estão sendo implementadas por milhares de fabricantes de produtos e prestadores de serviços dos setores publico e privado.

NBR ISO 9000 - Serie de normas brasileiras da família ISO 9000 em português distribuídas pela ABNT.

NBR ISO 9000:2000 - Norma em português que descreve os fundamentos de sistema de Gestão da Qualidade e estabelece a terminologia para estes sistemas. Válida a partir de 29.01.2001 (cancelou e substituiu as anteriores NBR ISO 8402; NBR ISO 9000-1 e NBR ISO 9000-2).

NBR ISO 9001:2000 - Norma em português que especifica requisitos para um sistema de Gestão da Qualidade e objetiva aumentar a satisfação do cliente. Válida a partir de 29.01.2001 (cancelou e substituiu as anteriores NBR ISO 9002; NBR ISO 9003, e substituiu a anterior NBR ISO 9001).

NBR ISO 9004:2000 - Norma em português que fornece diretrizes que consideram tanto a eficácia como a eficiência do sistema de Gestão da Qualidade. O objetivo desta norma é 
melhorar o desempenho da organização e a satisfação dos clientes e das outras partes interessadas. Válida a partir de 29.01.2001 (cancelou e substituiu as normas anteriores NBR ISO 9004-1; NBR ISO 9004-2 e NBR ISO 9004-3).

NBR ISO 19011:2002 - Norma em português que fornece diretrizes sobre auditoria de sistemas de Gestão da Qualidade e/ou ambiental. Válida a partir de 29.12.2002. (substituiu as normas NBR ISO 10011-1; NBR ISO 10011-2; NBR ISO 10011-3; NBR ISO 14010; NBR ISO 14011 e NBR ISO 14012).

JUSE Japanese Union of Scientists and Engineers - Sindicato Japonês de cientistas e engenheiros.

Know-how - Aptidão especial compreendendo perícia e habilidade para executar um trabalho ou resolver um problema.

Lista de verificação (Checklist) - Documento que relaciona ações e providências relativas a tarefas e atividades de execução, análise, controle, auditoria ou Garantia da Qualidade, estabelecidas em manuais, procedimentos ou instruções do Sistema da Qualidade, com objetivo de chamar a atenção, orientar, padronizar e registrar essas ações e providências.

Macroprocesso - Sistema operacional que envolve um grande número de tarefas interfuncionais, sendo conduzido normalmente conduzido em várias áreas de uma organização.

Manual da qualidade MQ - Documento que descreve o Sistema da Qualidade de uma organização, especificando a política, diretrizes, atribuições, responsabilidades e procedimentos adotados para a execução de todas as atividades que possam vir a influenciar a qualidade, bem como as formas de controle.

Mapeamento de processo - Conjunto de atividades sistematizadas com objetivos de atribuir responsabilidades; identificar atividades fragmentadas por diversos departamentos ou áreas, as quais devem ser reagrupadas; determinar atividades repetitivas sem valor agregado ou que não possuem cliente, as quais devem ser eliminadas; identificar desperdícios, gargalos, burocracia, perdas de tempo, duplicações e repetições, a fim de eliminá-los; identificar tarefas que, mesmo acrescentando valor, podem ser simplificadas; e descobrir atividades auxiliares que não fazem parte da missão da empresa e que podem ser terceirizadas com vantagens operacionais de qualidade e custo.

Melhoria continua da qualidade - Esforço contínuo de melhoria da qualidade, sustentado no decorrer do tempo, que age sobre os processos, produtos e serviços, em termos humanos e tecnológicos, com o objetivo de garantir que o nível de qualidade seja sempre mais alto do que o custo competitivo.

Método 5W1H (What, Why, When, Where, Who, How) - Tipo de lista de verificação utilizado para informar e assegurar o cumprimento de um conjunto de planos de ação. Ultimamente tem-se incluído mais um $\mathrm{H}$ (how much), transformando o método em 5W2H (o que, por quê, quando, onde, quem, como e quanto custa).

Motivação para a qualidade - Fator consciente ou inconsciente que influencia as decisões individuais e orienta os comportamentos em prol da qualidade.

Não-conformidade - Estado ou condição de um sistema, processo, produto, ou serviço em que há uma ou mais características não conformes com a especificação ou outro padrão de desempenho ou inspeção. 
Organização - Empresa, firma, instituição, estabelecimento, empreendimento ou grupo, público ou privado, que compra e vende materiais, itens, produtos ou presta serviços, com ou sem finalidade lucrativa.

Organograma - É representação esquemática de uma estrutura social que dispõe os diversos elementos componentes da organização em extratos de autoridade, assim como do seu relacionamento hierárquico - funcional.

Padrão - Conjunto de normas, procedimentos, instruções, diretrizes e planos de ação estabelecidos pela administração de uma organização, de forma a possibilitar a execução padronizada de todas as principais operações, processos, atividades e tarefas.

Padrão da qualidade - Referencial utilizado como base de comparação para avaliação da qualidade de um material, item, produto, serviço, processo ou sistema.

Padrão de qualidade - Modelo de qualidade implantado ou a ser seguido por uma organização, em decorrência de exigência de clientes ou legal, ou ainda por opção/capacitação da própria organização.

Padronização - Redução do número de características ou especificidades de um sistema ou redução do número de formas que podem variar ou interagir. Isto é a padronização unifica e simplifica atividades segundo padrões ou modelos pré-estabelecidos, por iniciativa da própria empresa, impostos por legislação ou em função de novos hábitos e costumes do cliente.

Pensamento sistêmico - Percepção e compreensão das organizações de forma integrada e dinâmica.

Planejamento da qualidade - Conjunto de atividades que visam determinar as necessidades e expectativas do cliente e desenvolver produtos, serviços e processos para suprir essas necessidades e expectativas.

Plano de Ação - Plano que descreve as orientações de médio e longo prazos da administração, com objetivos, metas e formas de avaliação.

Política da qualidade - conjunto de intenções, diretrizes e objetivos de uma organização relativos à qualidade, formalmente expressos pela alta administração. É um guia de ação gerencial.

Precisão - Grau de dispersão de uma variável numa distribuição de resultados obtidos da aplicação, por muitas vezes, dos procedimentos estabelecidos, sob as mesmas condições definidas.

Procedimento organizacional - Documento de caráter técnico administrativo, interfuncional, que serve para orientar e facilitar o entendimento dos funcionários quanto às diretrizes que normalizam os sistemas e/ou atividades da organização, retratando seus diversos objetivos e responsabilidades.

Processo - Conjunto sistemático de operações, tarefas, etapas, ciclos de trabalho etc. através do qual uma organização cumpre sua missão. Qualquer que sejam os fatores, sua combinação deve ser definível, repetível e previsível.

Processo de negócio - Conjunto de atividades planejadas com o objetivo de se oferecer um produto ou serviço específico para um determinado mercado ou tipo de cliente. A ênfase é no modo de execução dos trabalhos e em sua melhoria. 
Produtividade - Relação entre o output produzido e o input requerido para produzi-lo. Em outras palavras é a medida do rendimento de um processo, setor ou organização (setor econômico de mercado, país etc.) na forma de uma relação entre o valor da produção e o custo da mesma.

Produto - Resultado de atividades, operações ou processos. Num sentido amplo, pode significar matéria-prima, material, insumo, componente, produto intermediário, produto acabado (ou final), material de embalagem, instrumento, máquina, equipamento, serviço, material processado, "software”, "hardware” ou uma combinação entre eles. Pode ser tangível (como um material processado/ montado) ou intangível (como uma informação ou conceito) ou uma combinação dos dois.

Produto não conforme - Qualquer produto (item, serviço ou quantidade de material) que apresente uma ou mais características fora dos limites de especificação ou que tenha um nível de variantes superior ao permitido pelo nível de qualidade aceitável.

Programa da qualidade - Conjunto de planos documentados contendo objetivos, estratégias, meios, métodos e metas requeridos para a implantação de um Sistema da Qualidade.

Qualidade - De forma sucinta, é o que o cliente quer e como ele julga. É um conceito sistemático de busca da excelência. A qualidade de um mesmo produto/serviço pode ser diferente para diferentes clientes e até para o mesmo cliente em diferentes tempos ou condições. O termo não é utilizado sozinho, para expressar um grau de excelência em sentido comparativo, nem é utilizado em um sentido quantitativo para avaliações técnicas. Para esses casos, devem-se usar adjetivos qualificativos, ou nível de qualidade.

Qualidade intrínseca - Conjunto de características da qualidade que conferem ao material, item, produto ou serviço garantia de cumprimento às especificações e a satisfação dos clientes.

Qualificação do pessoal - Característica e habilidades obtidas através de educação, treinamento e/ou experiência, medidas contra requisitos estabelecidos como padrões ou testes, que qualificam uma pessoa a desempenhar uma determinada função.

Qualificação técnica - Comprovação de um conjunto de conhecimentos e experiência que habilitam uma organização para o fornecimento de determinados produtos ou serviços, ou uma pessoa física para o exercício de determinada função.

Registro da qualidade - Conjunto de documentos ou informações registradas, por qualquer meio, tais como relatórios de auditoria, certificado de análise, atas do conselho da qualidade, relatórios de times da qualidade, coleta de dados resultantes de inspeção ou análise de discrepâncias, análise critica de dados etc., que são elaborados, atualizados e conservados com o objetivo de demonstrar que a qualidade requerida é obtida e que o Sistema da Qualidade funciona eficazmente, pois em grande parte a rastreabilidade do produto ou serviço depende essencialmente dessa condição.

Relatório de ações corretivas - Documento que relaciona ações a serem implementadas a fim de eliminar as causas e condições adversas à qualidade e evitar repetições.

Relatório técnico - Documento onde são registradas informações sobre matérias-primas, processos, operações, ensaios, condições de trabalho, desempenho, análise de panes ou falhas, reclamações de clientes etc., para orientações e consultas.

Requisito - Condição a ser atendida, necessariamente, por um fornecedor, contrato, sistema, processo, material, item, produto ou serviço. 
Retrabalho - Qualquer processo pelo qual um material, item, produto ou serviço defeituoso ou não-conforme é submetido à repetição de operações do processo produtivo de modo a satisfazer os requisitos originalmente especificados e, portanto, torná-lo em condições de ser aceito.

Satisfação de clientes - Reação do usuário que recebe produtos e/ou serviços visivelmente superiores a quaisquer outros do mercado, e no prazo.

Seqüência operacional - Seqüência lógica de todas as operações necessárias e suficientes para a operação e um item, material, produto, serviço ou sistema.

Serviço - Atividade caracterizada pela execução de tarefas, consideradas estas independentes dos itens aos quais se refiram. Em outras palavras é um produto da atividade humana, que sem assumir a forma de um bem material, satisfaz uma necessidade.

Sete ferramentas da qualidade - Métodos analíticos largamente utilizados para a solução de problemas em qualidade. São: folha de verificação, gráficos, histograma, diagrama de Pareto, diagrama de Ishikawa, diagrama de dispersão e gráfico (carta) de controle.

Sistema da qualidade - Estrutura organizacional, procedimentos, responsabilidades, processos, atividades e recursos para implementação da Gestão da Qualidade e atingimento dos objetivos da qualidade - garantia de que os projetos, processos, produtos e serviços irão satisfazer as necessidades e as expectativas explicitas e implícitas dos clientes, em consonância com a missão, os objetivos e as metas da organização.

Sistema de custos da qualidade - Sistemas de custos em separado da área financeira da organização, orientado aos produtos e/ou serviços que tem por objetivo primordial garantir que produtos e/ou serviços satisfaçam os clientes a um custo mínimo, contribuindo assim para maximizar os lucros.

Sistema de informação da qualidade - Sistema que tem por objetivos coletar, processar, analisar, informar e armazenar informações sobre a qualidade, de forma a subsidiar tomada de decisões em todos os níveis.

Subsistema - Parte de um conjunto de maquinas, equipamentos e componentes responsável por uma função operacional de um sistema.

Tabulação de dados - Coleta de dados relevantes a um determinado objeto ou situação a ser analisada.

Tarefa - Trabalho, ação ou conjunto de ações a serem realizadas para o cumprimento de determinada missão, objetivo ou meta, num determinado prazo.

Usuário - Pessoa que utiliza ou consome um produto ou serviço.

Zero defeito - É uma meta de longo prazo em direção à melhoria contínua da qualidade e necessariamente influenciada por todas as funções em uma empresa. Na pratica é impossível e não interessante chegar-se-á, literalmente, zero defeito, já que o custo da qualidade tenderia ao infinito. 
APÊNDICE A - Questionário submetido às Empresas de Posicionamento com o Sistema GPS 


\author{
UNIVERSIDADE DE SÃO PAULO \\ ESCOLA DE ENGENHARIA DE SÃO CARLOS \\ DEPARTAMENTO DE TRANSPORTES \\ Programa de Pós-Graduação \\ Av. Trabalhador Sãocarlense, 400 \\ CEP 13560-590 São Carlos - SP
}

Prezado(a) Senhor(a)

Atualmente a crescente busca por produtos e serviços com qualidade tem levado as empresas a adotarem políticas de qualidade como uma estratégia que favoreça o aumento da produtividade e competitividade e garanta sempre a satisfação do cliente.

Para saber como as Empresas/Profissionais do setor de serviços com GPS tratam essa questão, estamos realizando uma pesquisa e solicitamos sua colaboração no preenchimento do questionário no link abaixo.

Suas respostas serão mantidas confidenciais e destinam-se unicamente para fins acadêmicos.

Após responder as questões formuladas, pedimos a gentileza de enviarnos.

Quaisquer dúvidas poderão ser esclarecidas com Artur pelos telefones:

(16) 3373-9612, (16) 3361-9863 ou (16) 9713-1510.

e-mail:apm@sc.usp.br

Desde já, muito obrigado pela colaboração.

Atenciosamente,

$$
\begin{gathered}
\text { Artur Pantoja Marques } \\
\text { Doutorando - EESC - USP }
\end{gathered}
$$

Para acessar o questionário clique no link:

http://143.107.234.83/wgps/bd_interface/Resultados/submission_form.asp 


\section{Formulário de questões $\quad \underline{\text { Home }} \mid \underline{\text { Sair }}$}

Caso haja interesse em receber a compilação dos resultados dessa pesquisa (selecione aqui $\square$ ), esses serão enviados assim que forem concluídos.

1. Indique a sua opção de preenchimento: $\bigcirc$ Empresa $\bigcirc$ Profissional Liberal

\section{Identificação}

Nome:

E-mail:

Empresa:

Endereço:

CEP:

Cidade:
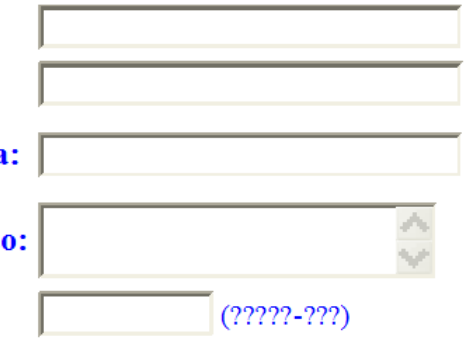

\section{Cidade:}

3. Caracteristicas da Empresa/Profissional*

3. Características da Empresa/Profissional*

Ano de fundação: *Ramo de Atividade:

\begin{tabular}{|c|c|c|c|}
\hline (aаa) & $\lceil$ Topografia & ГGeodésia/GPS & ГFotogrametria \\
\hline & $\lceil\mathbf{S I G}$ & $\lceil$ Outro & \\
\hline $\mathrm{N}^{0}$. Funcionários: & *Principais Clientes: & & $\bar{A}$ \\
\hline
\end{tabular}

\section{Gestão da Qualidade}

4.1. Qual a situação atual da Empresa/Profissional com relação a Gestão da Qualidade?
a. Plenamente implantada (ir p/ item 4.3)
b. $\curvearrowright$ Em implantação (ir p/ item 4.3)
c. $\bigcirc$ Ainda não pratica

4.2. Caso tenha marcado o item "c" anterior, qual sua posição com relação ao assunto?
a. $\bigcirc$ Planeja implantar no futuro (ir $\mathrm{p} /$ item 5.0)
b. $\subset$ Está analisando a implantação (ir p/ item 5.0)
c. $C$ Não pensa em implantar (ir p/ item 5.0)

4.3. Que base conceitual foi adotada como diretriz para implantação da Gestão da Qualidade?
a. Gestão ou Controle da Qualidade Total (TQM/TQC)
b. Normas NBR ISO Série 9000
c. $\bigcirc$ Outra

4.4. A empresa tem certificado de Qualidade?
a. $\bigcirc \operatorname{Sim}$
Qual:
b. $\subset$ Não

4.5. Quais indicadores de desempenho quanto a Qualidade a empresa possui? 

a. Qualitativos $\Gamma$ Auditorias
ГInformações do Cliente
$\Gamma$ Avaliação Externa
b. Quantitativos $\Gamma$ Índices da Qualidade $\Gamma$ Custos da Qualidade
c. Ambos anteriores
d. $\curvearrowright$ Outros
e. Nenhum

\section{Processo produtivo do Sistema GPS (Empresa/Profissional)}

5.1. A Empresa usa algum procedimento para garantir a Qualidade dos serviços com GPS?
a. Sim Qual?
b. N Não Porque?

5.2. Indique os materiais de apoio que fazem parte de sua base para a execução dos serviços com GPS? (pressione Ctrl para seleção múltipla)
a. $Г$ Normas
ABNT NBR 13.133 Execução de Levantamento Topográfico ABNT NBR 14.166 Rede de Referência Cadastral Municipal - Procedimento
b. Г Especificações BGE PR 22(21.07.83) Especificacõos e Normas Gerais para Levantamentos Geodésicos
c. Г Padrões/Leis.. IBGE PR 23(21.02.89) Parametros para Transformação de Sistemas Geodésicos
Decreto 89.817(20.06.84) BR Instruções Reguladoras das Normas Técnicas da Cartografia Nacional IBGE DG 29(22.07.88) Padronização de Marcos Geodésicos: Instrução Técnica
d. $\Gamma$ Outros
e. $\lceil$ Nenhum

5.3. Indique quais equipamentos normalmente são usados para execução dos serviços com GPS:

\begin{tabular}{|c|c|c|c|}
\hline ГNavegação & $\lceil$ Topográfico & $\lceil$ Geodésico & $\lceil$ Tempo Real \\
\hline Outro & & & \\
\hline$Г$ Micro/Softwares & $\lceil$ Impressora & $\lceil$ Plotter & $Г$ Scanner \\
\hline
\end{tabular}

5.4. Qual opção melhor reflete a condição de seus equipamentos?
$\checkmark$ todos próprios
$\checkmark$ todos alugados
$\checkmark$ alguns próprios e outros alugados

5.5. Indique qual opção melhor expressa a freqüência de calibração/Aferição dos equipamentos?
nunca foram
não definida
$\checkmark$ antes dos serviços
C sempre que necessário

5.6. Onde é feita a calibração com certificado?

$\subset$ Lab. próprio $\subset$ Fabricante $\odot$ Instituto credenciado $\odot$ Outros

5.7. Quantos funcionários trabalham com GPS?
a. Quantos engenheiros?
Qual formação?
Engenheiro Agrimensor
(pressione Ctrl para seleção múltipla)
b. Quantos técnicos?
Qual formação?
(pressione Ctrl para seleção múltipla)
Técnico em Agrimensura
Técnico Agrônomo
a. Outros profissionais?
Qual formação?

5.8. A maioria de seus serviços com GPS são contratados com base em:

c Publicidade
Indicação de outros Clientes
Não avaliado 
5.9. O que normalmente seus Clientes exigem como garantia para contratação dos serviços com GPS?

5.10. Com relação aos materiais de apoio técnico hoje disponibilizados para posicionamento com GPS (orgãos nacionais), o que melhor expressa sua opinião?
a. $\subset$ Estão plenamente atualizados
b. $\subset$ Estão desatualizados
c. $\subset$ Estão incompletos
d. $\subset$ Outra opinião:

5.11. Com relação a lei 10.267/01 do INCRA que criou o Sistema Público de Registro de Terras qual opção melhor expressa a sua condição atual?
a. Conhecedor Pleno
b. $\odot$ Já li alguma coisa a respeito
c. $\subset$ Não conheço nada
d. $\odot$ Outra condição:

\section{Geral}

6.1 Espaço para comentários. 
APÊNDICE B - Resultados da pesquisa social aplicada a empresas de GPS 
A pesquisa sobre a situação das empresas prestadoras de serviços de posicionamento com o sistema GPS no Brasil envolveu um total de 120 empresas, das quais 105 responderam e participaram efetivamente. Os resultados e conclusões são mostrados a seguir.

A diversidade de empresas que prestam os serviços de posicionamento com o sistema GPS no Brasil, tais como escritórios de engenharia e projetos, escritórios de topografia, empresas construtoras, e outras, que o têm como atividade paralela, dificultaram a adoção de uma amostra representativa para a pesquisa. Diante disso, a característica mais importante de escolha da empresa foi sua atividade principal.

As empresas foram selecionadas nas cinco regiões do Brasil (Norte, Nordeste, CentroOeste, Sudeste e Sul) e a quantidade de empresas por região mostra uma maior concentração nas regiões sul e sudeste, fato que pode ser explicado pelo maior índice de desenvolvimento econômico dessas regiões (Tabela 15).

\section{Tabela 15 - Questionários recebidos por região}

\begin{tabular}{ccc}
\hline Região & \multicolumn{2}{c}{ Empresas participantes } \\
\hline Norte: & 5 & $4,8 \%$ \\
Nordeste & 7 & $6,7 \%$ \\
Centro Oeste & 8 & $7,6 \%$ \\
Sudeste & 58 & $55,2 \%$ \\
Sul & 27 & $25,7 \%$ \\
\hline Total & $\mathbf{1 0 5}$ & $\mathbf{1 0 0} \%$ \\
\hline
\end{tabular}

Dos 105 questionários respondidos, foi possível caracterizar o perfil das empresas que prestam serviços de posicionamento com o sistema GPS, e que representam a maioria dos resultados:

- são formadas por sociedade (dois sócios responsáveis técnicos);

- são caracterizadas como pequenas empresas prestadoras de serviços;

- têm, em média, 4 ou 5 funcionários;

- os equipamentos são próprios;

Nas empresas pesquisadas observa-se uma ausência considerável (Figura 42) do uso de sistemas de Gestão da Qualidade. A maior justificativa é o desconhecimento do assunto, 
ou seja, apesar da maioria das empresas ser formal, cerca de $88 \%$ adotam meios informais de gestão, cujas causas não foram aqui pesquisadas, e apenas uma pequena parte, equivalente a $12 \%$, adota controles formais com as vantagens proporcionadas por um sistema de Gestão da Qualidade.

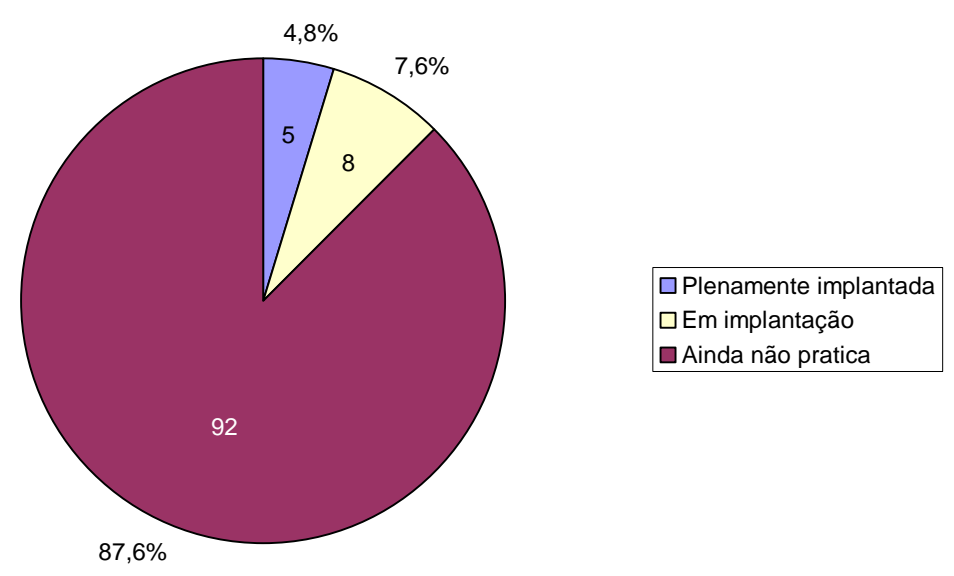

Figura 42 - Situação das empresas de GPS com relação à GQ.

A pequena parcela de empresas (13) que adota ou está implantando um Sistema de Gestão da Qualidade, tem como base conceitual de referência as Normas da Série NBR ISO 9000. Embora tenha sido questionado, não houve uma explicação mais técnica sobre o motivo. Dessas empresas apenas uma declarou ter certificação ISO 9001:2000, outras 3 manifestaram que a certificação não é seu objetivo e as demais não se manifestaram.

Para as outras empresas consultadas que adotam meios informais de gestão (92), a grande maioria, correspondente a 87\% delas (Figura 43) está analisando ou planejando adotar, em um futuro próximo, algum sistema formal de Gestão da Qualidade que possibilite maior controle e garantia de seus serviços. O motivo principal, segundo a resposta da maioria delas, são as constantes exigências contratuais dos clientes e do mercado.

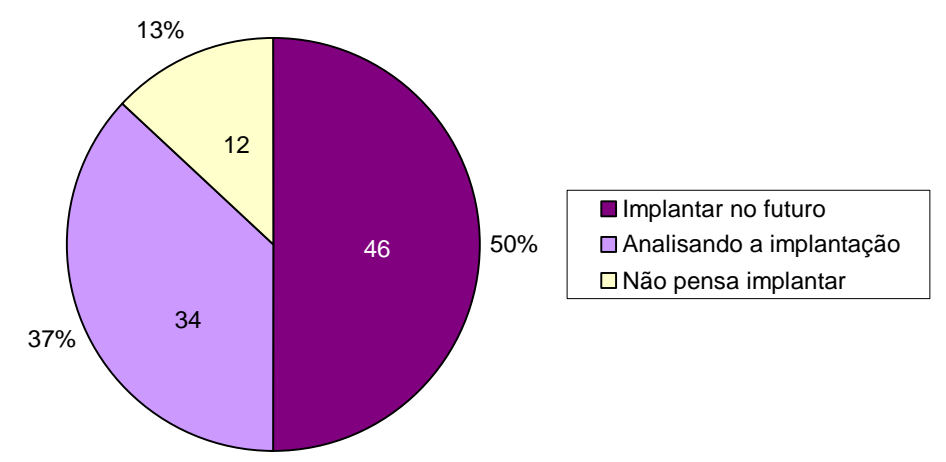

Figura 43 - $\quad$ O que pensam as empresas que ainda não praticam a GQ 
Das respostas dadas na pesquisa, verificou-se que a maioria das empresas adota procedimentos para garantir a qualidade de seus serviços, que variam desde simples inspeções até procedimentos mais rigorosos realizados nas diversas etapas de que compõe o serviço de posicionamento com o Sistema GPS. Verifica-se também que não há um procedimento padrão, isto é, cada responsável adota o procedimento que melhor lhe convier e lhe for favorável, embora nem sempre seja o mais correto e completo, pois falta uma definição clara do que, como e quando realmente deve ser usado.

Entre os diversos materiais usados como base de apoio técnico para execução dos serviços de posicionamento com o sistema GPS, tais como Normas e Especificações Técnicas, recomendações dos fabricantes e padrões pessoais, a maioria das respostas enfoca uma enorme carência de material técnico mais claro, prático, em português e que apresente exemplos de situações mais comuns aplicadas à execução dos serviços.

Com relação aos equipamentos empregados na execução dos serviços, a maioria das empresas tem seus próprios equipamentos GPS que normalmente são de uma freqüência (L1 - topográfico) e, quando necessários, equipamentos de dupla freqüência (L1/L2 geodésico) geralmente são alugados.

Um outro fato que chamou atenção nesta pesquisa está relacionado à forma de contratação dos serviços das empresas. Segundo as respostas, a maior parcela vem da indicação de outros clientes, ou seja, um cliente satisfeito traz mais cliente, mostrando que existe uma relação muito maior com o cliente e que este influi significativamente na vida da empresa (Figura 44).

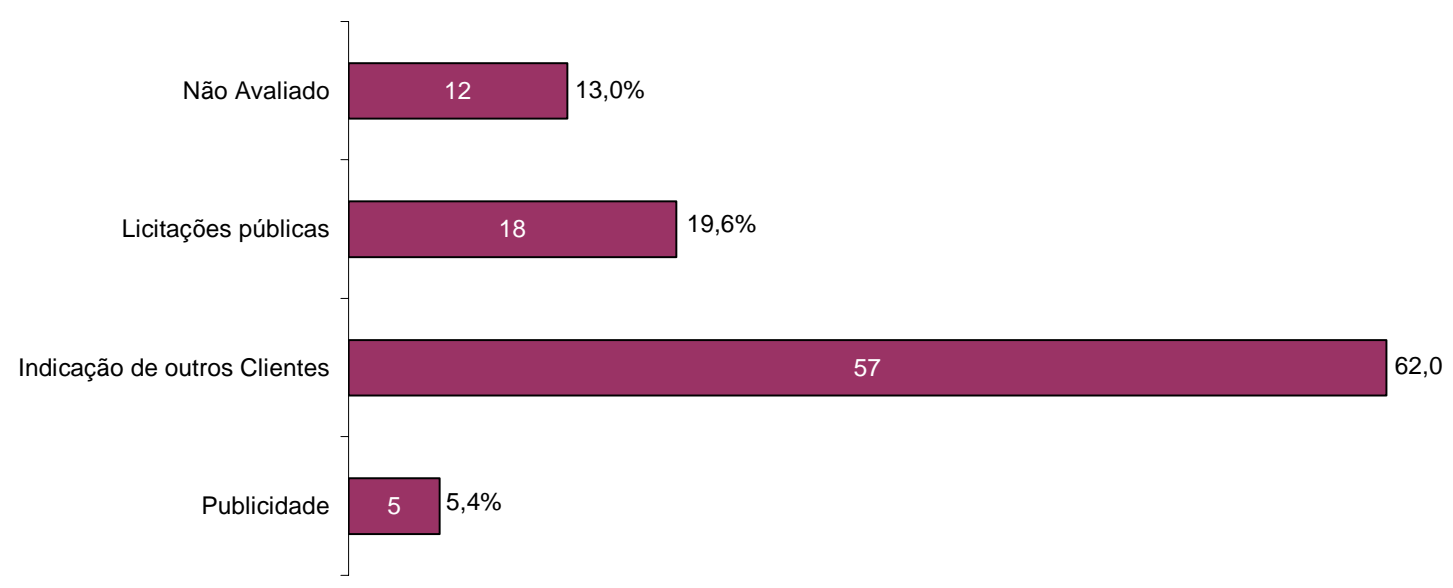

Figura 44 - Forma de contratação de serviços da empresa 
Ainda de acordo com as respostas das empresas pesquisadas, 43\% dos clientes dos serviços de posicionamento com o sistema GPS não fazem qualquer exigência como garantia para contratar um serviço (Figura 45). Isso pode ser resultado de um fato comum à maioria dos serviços de engenharia que requerem conhecimentos técnicos específicos por parte do cliente, como é o caso. Entretanto, observa-se que muitos clientes, mesmo sem embasamento técnico suficiente, mas com base no código do consumidor, por exemplo, têm tomado consciência de seus direitos e exigido formas de comprovação da qualidade técnica da empresa, por meio de registro em organismos oficiais de classes e atestados e certificados de capacitação técnica.

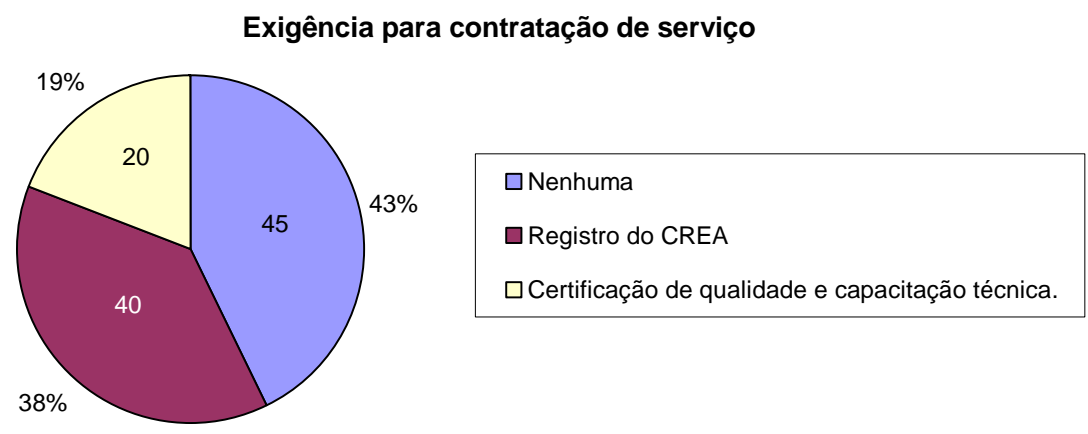

Figura 45 - Garantia exigida pelos clientes

Com a intenção de saber qual o assunto que as empresas gostariam de saber mais, em cerca de 58\% das respostas foram relacionadas a Gestão da Qualidade e a padronização de processos que estão intimamente relacionadas (Figura 46). Este fato motivou ainda mais o desenvolvimento desta tese. Outro assunto, que também foi bastante pedido, está relacionado às normas e especificações técnicas que, segundo as respostas, estão desatualizadas e não contemplam os novos métodos e técnicas de posicionamento com o sistema GPS.

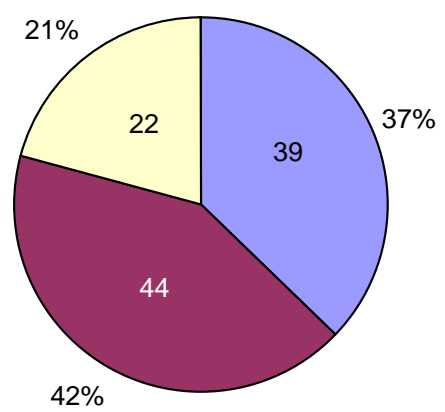

$\square$ Gestão da qualidade total

$\square$ Normas e especificações

$\square$ Padronização de processos

Figura 46 - Assunto que as empresas gostariam de saber mais 
Esta pesquisa social foi realizada com algumas empresas que prestam serviços de posicionamento com o sistema GPS, e apresentou resultado satisfatório com relação ao seu objetivo. Por meio da análise das respostas dos questionários recebidos, foi possível conhecer melhor como está o setor de posicionamento com GPS.

As respostas mostraram que a maioria das empresas pesquisadas não adota métodos formais de Gestão da Qualidade, mas está analisando e/ou disposta a implantar em um futuro próximo. Acredita-se que a crescente competitividade do setor proporcionada principalmente pelas novas frentes de serviços geradas a partir da lei 10.267 do INCRA (que trata da obrigatoriedade do georreferenciamento de imóveis rurais) (Brasil, 2001), possa efetivamente aumentar as exigências e a qualidade dos serviços prestados.

É certo que, com a globalização e as crescentes tecnologias disponíveis para execução de serviços de posicionamento com GPS (incluindo os novos sistemas GNSS), os profissionais das mais diversas áreas de formação (CONFEA, 2004) ficarão sujeitos às pressões de um mercado altamente competitivo. E por uma questão de sobrevivência, mais do que nunca precisarão de estratégias diferenciais que possam conquistar e satisfazer as exigências do cliente.

Os sucessos dos vários setores da indústria de transformação mostram que atender as exigências dos clientes e se firmar no mercado com qualidade, produtividade e diminuição de custos, são mais facilmente obtidos por meio da adoção de um Sistema da Qualidade capaz de fornecer as diretrizes para a organização gerenciar seus recursos (financeiros, materiais e humanos), ser competitiva e gerar lucro. 
APÊNDICE C - Registros de um posicionamento de campo com GPS (Exemplo Estático) 
Os registros apresentados aqui se referem a uma aplicação limitada de padrões de qualidade em um posicionamento com GPS, conforme preconizado na proposta modelo de Gestão da Qualidade. Seu principal objetivo é ilustrar as vantagens obtidas (mesmo que parcial) com a implementação de um SGQ e, neste caso especifico, representando apenas a parte produtiva da organização.

\section{Características básicas da organização executora}

Equipe técnica (especializada) responsável pelos serviços é composta por:

- 2 engenheiros

- 2 técnicos

\section{Materiais/equipamentos disponíveis para o projeto:}

- 3 receptores GPS geodésicos (L1/L2) e acessórios (hardware e software);

- 1 receptor GPS de navegação;

- 1 sala (escritório) contendo 3 computadores (1 portátil), impressoras, scanner e softwares específicos;

- materiais de escritório, pranchetas, planilhas e documentos em geral;

- equipamentos de comunicação (celulares e rádios) e acessórios;

- ferramentas de apoio (trena, marreta, facão, foice, cavadeira, pincel, lanterna etc.);

- $\quad$ artefatos de madeira e concreto (piquetes, estacas e marcos);

- EPI - Equipamentos de proteção individual (botas, coletes, luvas, óculos etc.);

- veículo para transporte

Conforme mencionado anteriormente, foram desconsideradas as ações e os processos administrativos (comercial/pessoal/jurídico) e considerada apenas a parte técnica produtiva do serviço, que foi executada nas seguintes fases:

- pedido do cliente;

- pré-planejamento;

- reconhecimento e implantação;

- projeto;

- levantamento de campo;

- processamento dos dados; e,

- relatório final. 


\section{O pedido do Cliente}

\section{Identificação:}

Cliente: J. O. A. N.

Endereço: Escola de Engenharia de São Carlos - USP - Depto. de Transportes

Outras informações: contato, telefone, e-mail etc.

Assunto: posicionamento de pontos para controle topográfico/geodésico com GPS.

Observação: o cliente é da área e tem conhecimento do assunto.

\section{Descrição:}

- o cliente explicou que precisa de um posicionamento de 7 pares de pontos topográficos, cuja finalidade é servir de apoio e controle para um trabalho de investigação a ser desenvolvido por ele.

- os pontos devem ser materializados em concreto.

- a implantação dos pontos deve ser ao longo da rodovia SP-310, a partir de São Carlos e no sentido interior, com distâncias aproximadas de 20, 50, 75, 100, 150, 200 e $300 \mathrm{~km}$, respectivamente.

- os pontos devem ser "intervisíveis" e distar-se de aproximadamente 100m dentro da faixa de domínio.

- considerando a aplicação final dos resultados, o cliente foi informado das opções possíveis de ajustamento, e decidiu pelo controle das coordenadas dos pontos, obedecendo simplesmente ao fechamento das figuras com a determinação dos vetores das linhas de base. Portanto, não serão feitos ajustes de rede.

- o prazo combinado para entrega dos resultados é de 30 dias (contínuos) a partir da assinatura do contrato.

\section{Planejamento inicial}

Nesta etapa foram definidos e indicados os pontos considerando as descrições constantes no pedido do cliente e as exigências de precisão do serviço. Foram usados mapas e informações de pontos existentes, obtidos em nosso banco de dados, alguns órgãos públicos como (IBGE, IGC, DER) e na internet. Também foram providenciados os contatos e as autorizações formais, para execução do serviço, junto aos órgãos competentes. 
O resultado foi um mapa (Figura 47) contendo a indicação aproximada dos prováveis locais a serem implantados e todas as informações necessárias para que a equipe de reconhecimento e implantação executasse sua tarefa.

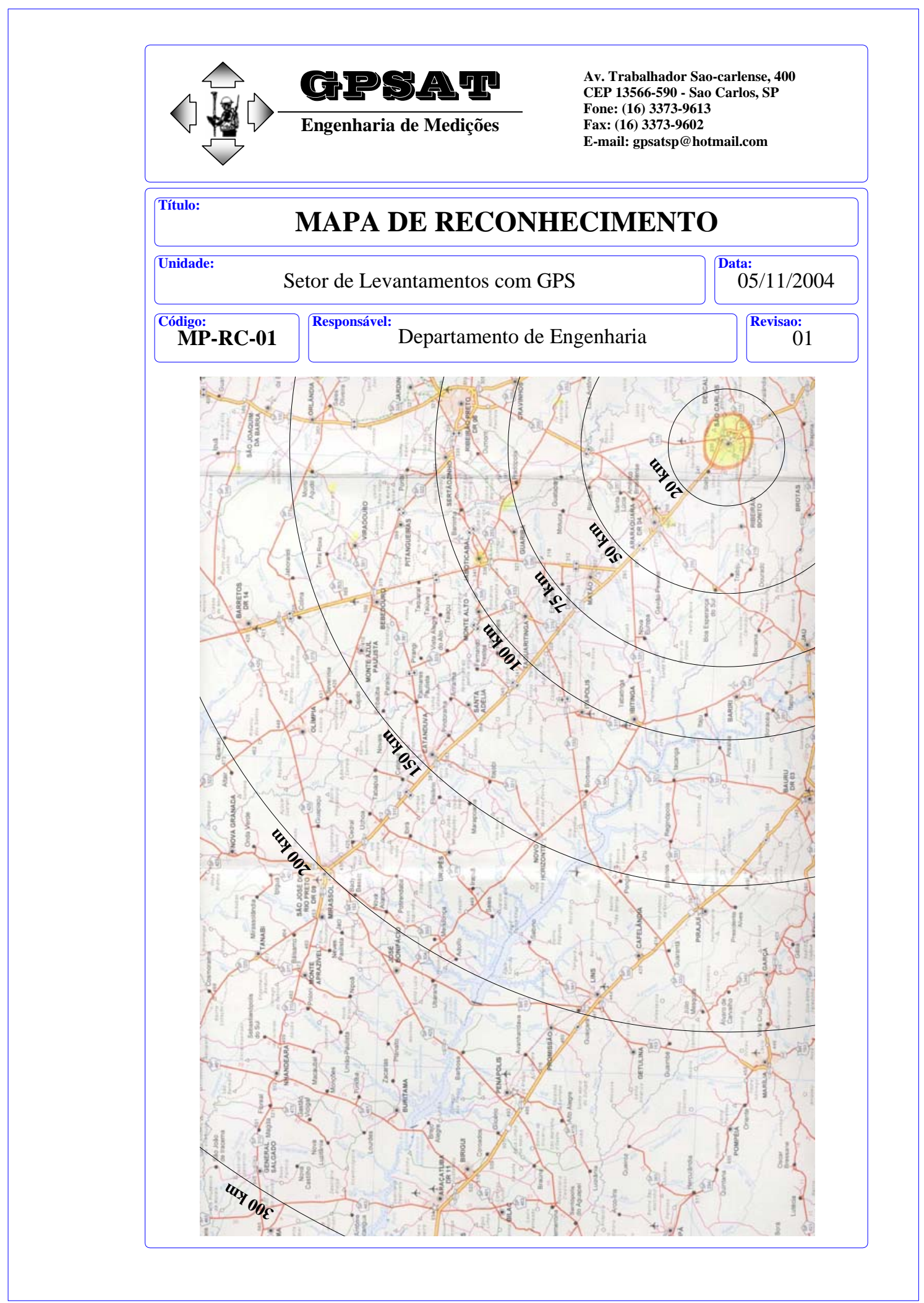

Figura 47 - Mapa de reconhecimento e implantação 
Nesta etapa também foi definido como método de trabalho a técnica de posicionamento relativo estático e o tipo de receptor GPS (L1/L2) para atender as exigências do cliente. Baseado nas recomendações do fabricante do instrumento, nas normas oficiais e na experiência da equipe, elaborou-se um cronograma para ocupação por ponto, tendo em vista, principalmente, a determinação e redução do custo envolvido.

A validação da técnica escolhida não foi necessária, pois já havia sido avaliada anteriormente em outros serviços similares feitos pela equipe. Apenas realizou-se um treinamento de rotina para avaliar o envolvimento dos membros da equipe.

\section{Reconhecimento e implantação}

Com as informações e documentos elaborados no pré-planejamento, a equipe separou os equipamentos e materiais necessários e foi ao campo, a fim de verificar e definir os locais a serem materializados os pontos. A escolha considerou os fatores indicados no pré-planejamento e outros primordiais recomendados, tais como ausência de obstruções e interferências, estabilidade, segurança, apoio logístico e necessidades de procedimentos especiais.

Após a definição do local, com aprovação total da equipe, procedeu-se à implantação do marco e, em seguida, foram feitos os registros de campo (descrição dos acessos, coordenadas aproximadas, mapa de obstruções, fotografias e anotações importantes). Os materiais e equipamentos utilizados nessa etapa foram conferidos e verificados um dia antes pela equipe. Entre eles:

- mapas, planilhas de registro e documentos de autorização;

- veículo;

- receptor GPS de navegação;

- computador portátil (lap-top) e máquina fotográfica;

- equipamentos de comunicação (celular e rádio comunicador);

- ferramentas gerais para limpeza e implantação dos marcos;

- marcos de concreto;

- EPI. 
Uma lista de verificação foi usada antes do inicio da etapa de reconhecimento, conforme ilustrado na Figura 48 a seguir:

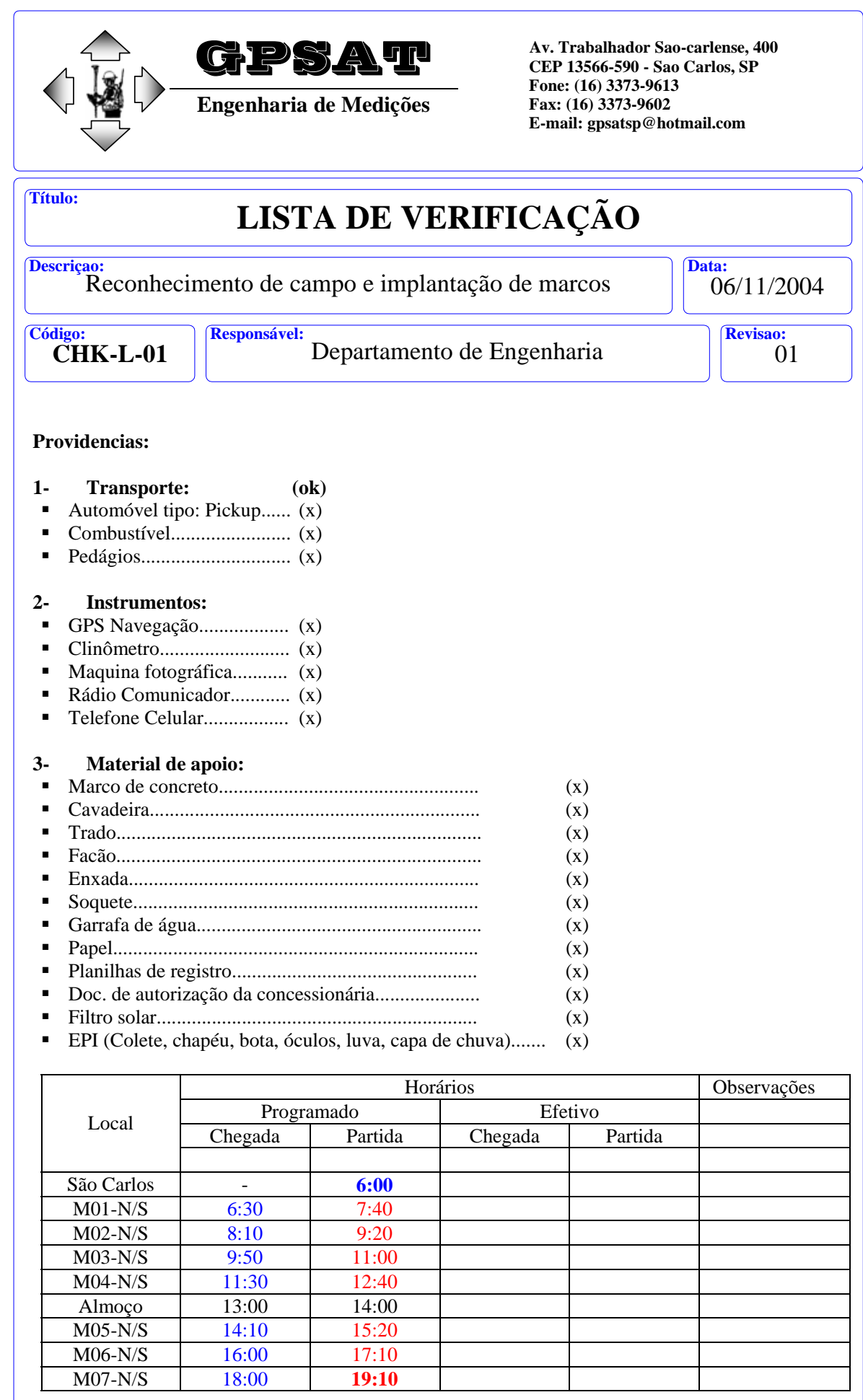

Figura 48 - Lista de verificação prévia do reconhecimento e implantação 
Os registros de campo foram feitos em planilhas padronizadas que posteriormente foram digitadas no banco de dados da empresa (Figuras 49 e 50).

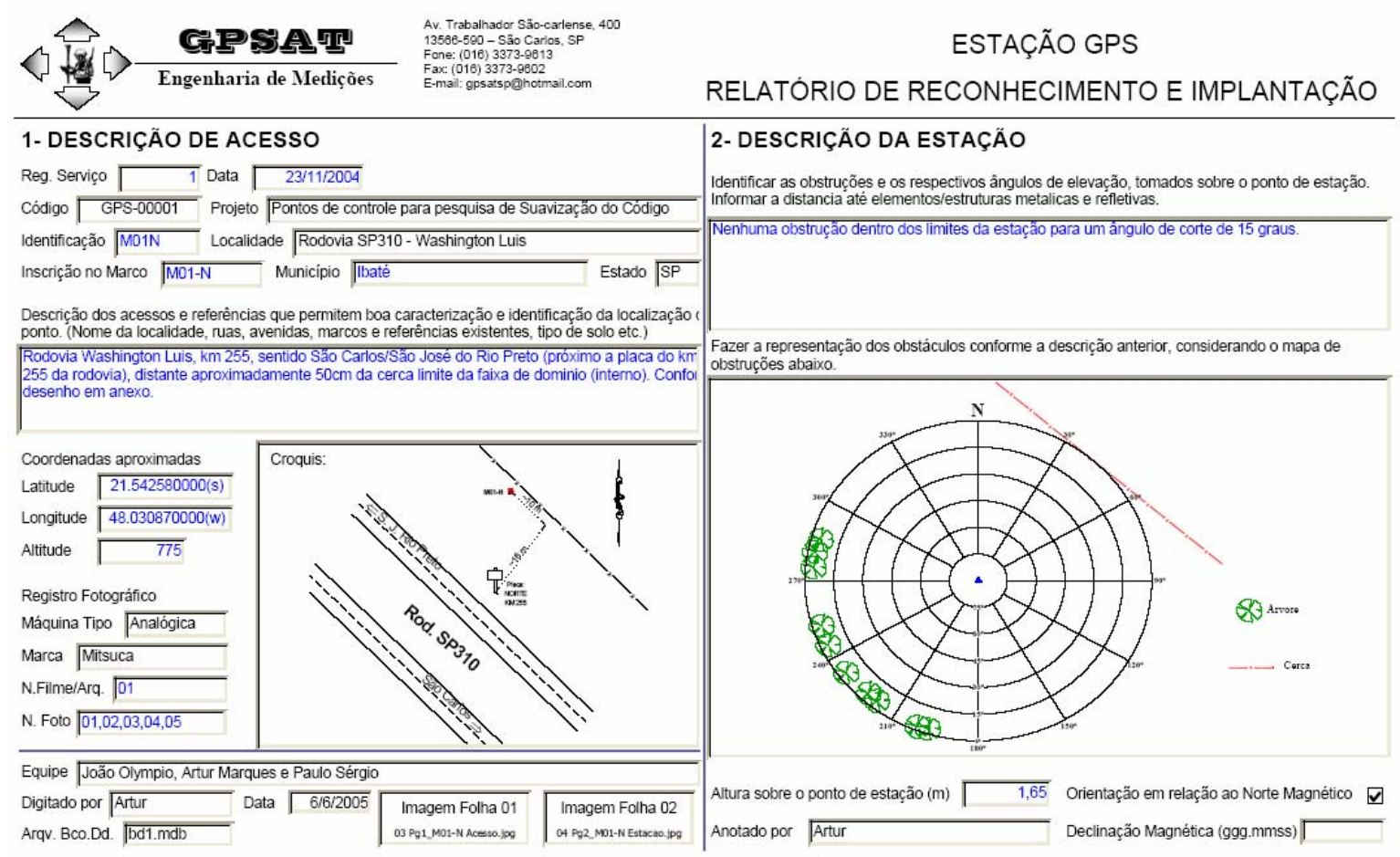

Figura 49 - Ponto M01-N - 20km (Folha A)

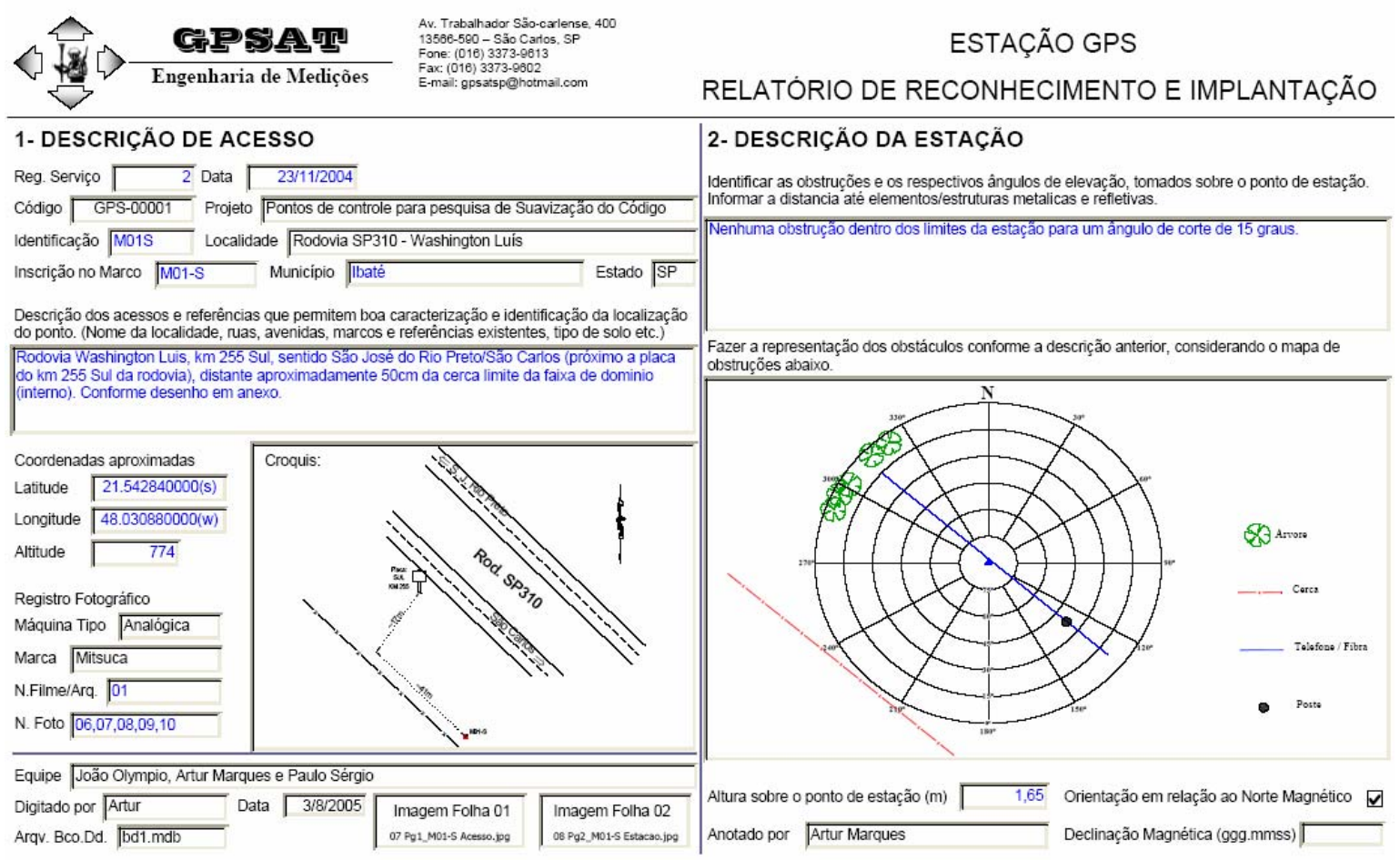

Figura 50 - Ponto M01-S - 20km (Folha B) 


\section{Projeto}

Com as informações da etapa de reconhecimento procedeu-se à elaboração do projeto definitivo do posicionamento, considerando as exigências de controle e configuração. Nesta etapa foram definidos os horários dos rastreios e deslocamentos, meios de transportes para o deslocamento, situações de logística, procedimentos de campo, providências de alojamento e alimentação, check-list de equipamentos e materiais, documentos e tudo que se faz necessário para uma perfeita execução de campo.

O resultado dessa etapa consiste em um conjunto de instruções para cada membro da equipe executar sua tarefa perfeitamente e com qualidade. Entre os materiais fornecidos incluem-se: manuais dos instrumentos, roteiro de instruções específicas para qualquer eventualidade, lista de questões e dúvidas mais freqüentes, mapas de localização com fotografias, indicações e descrições e mapas de projeto. As Figuras (51 a 48) a seguir ilustram alguns desses elementos:

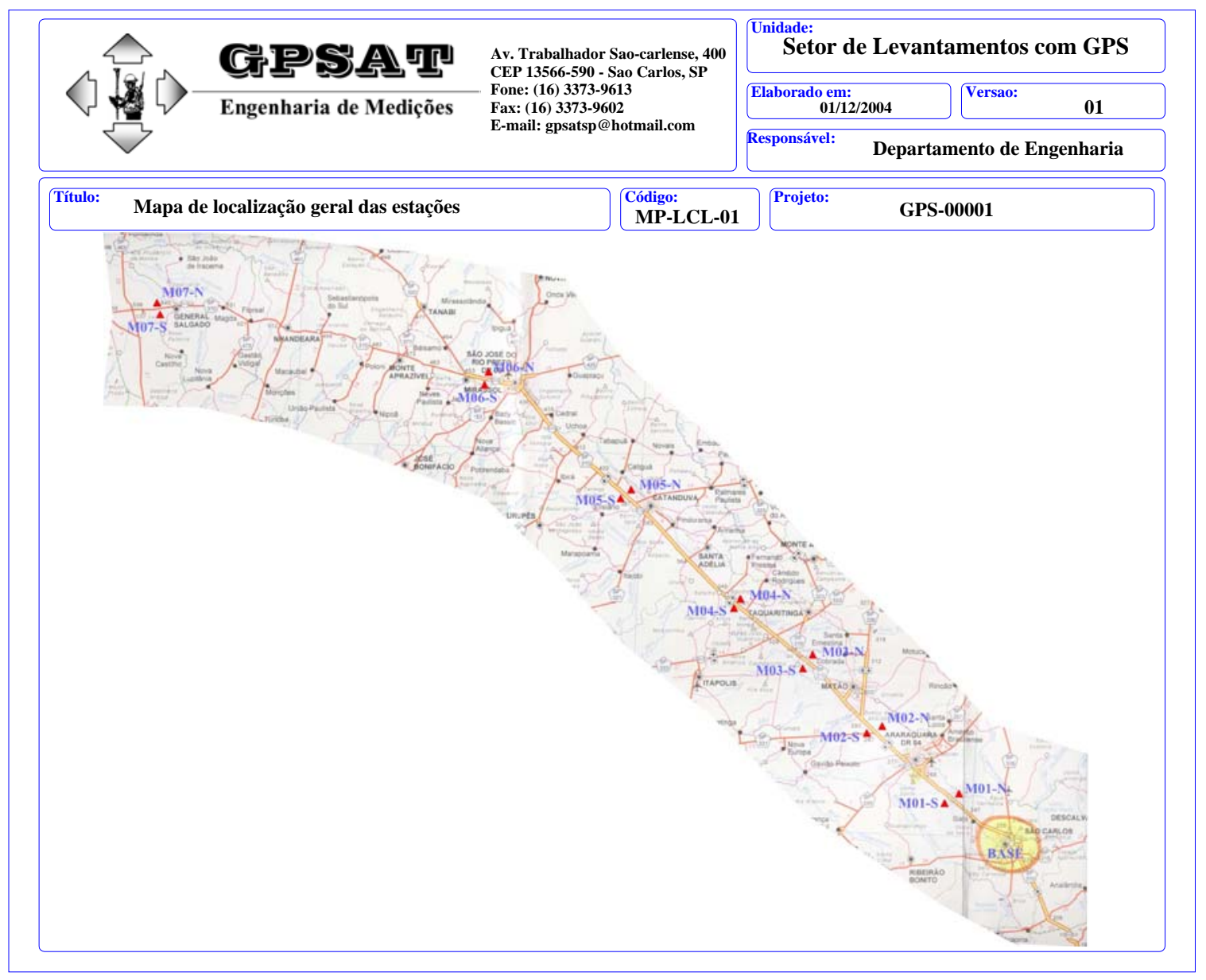

Figura 51 - Mapa de localização geral das estações do projeto 


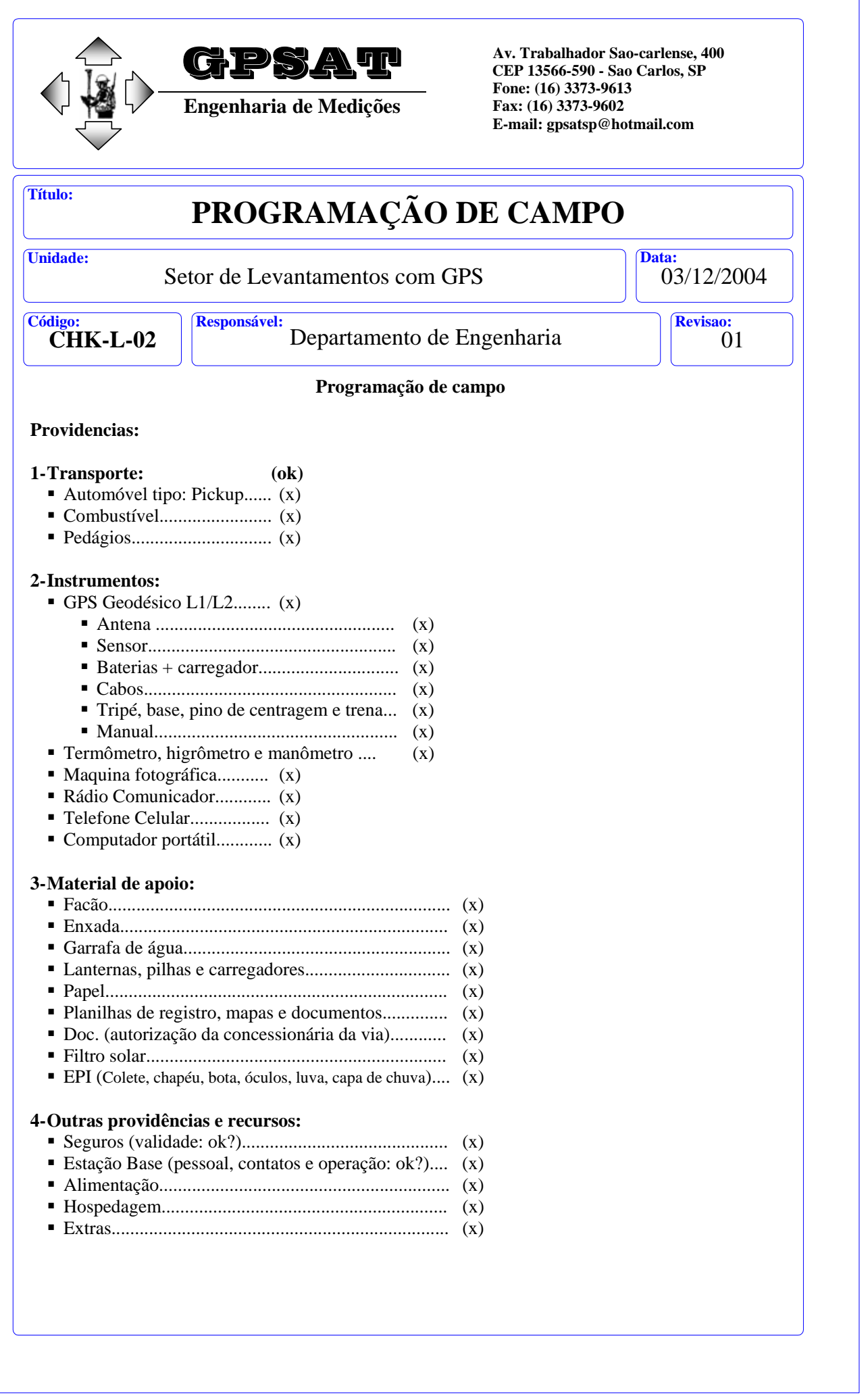

Figura 52 - Programação de campo (Folha1) 


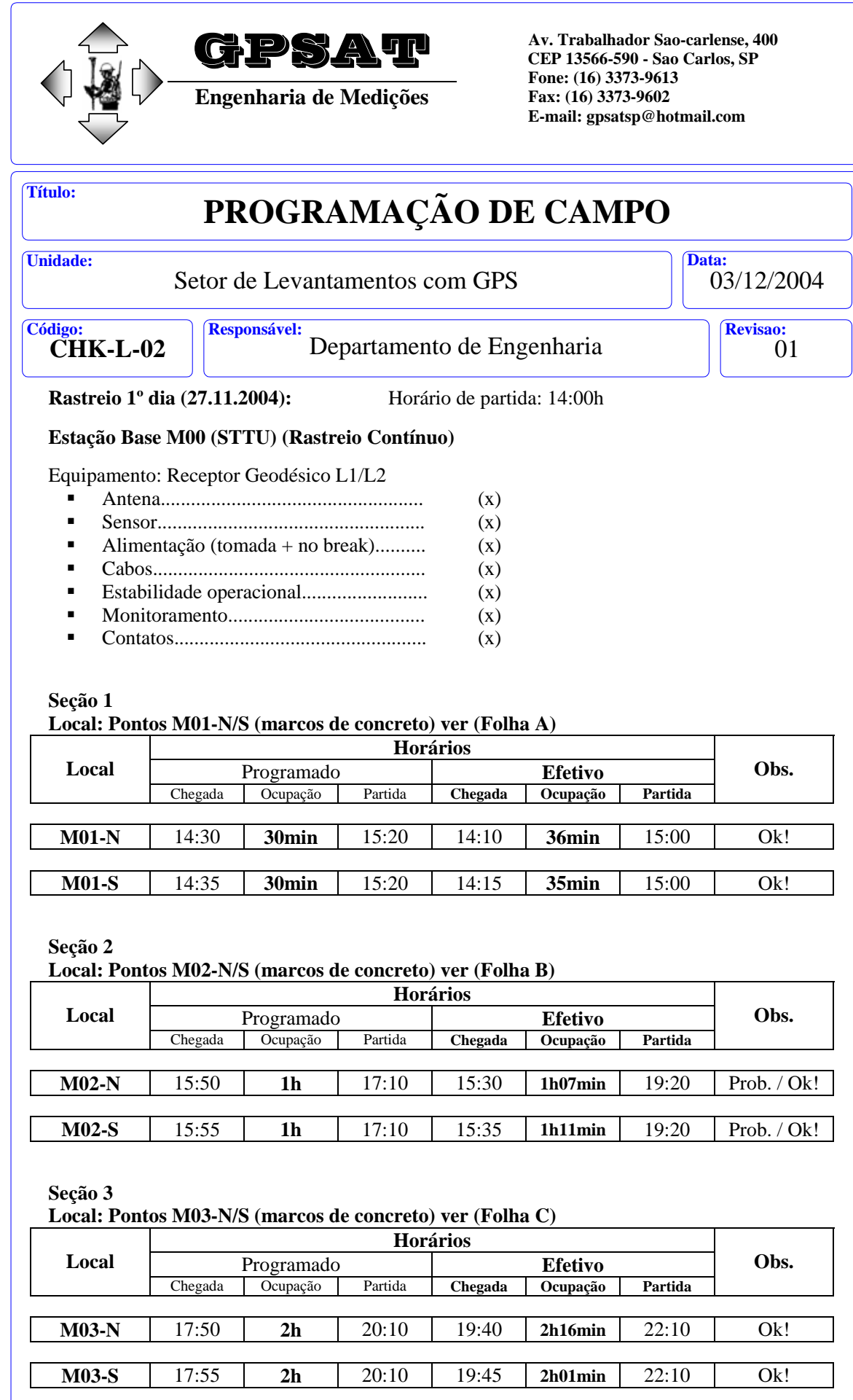

Figura 53 - Programação de campo (Folha2) 


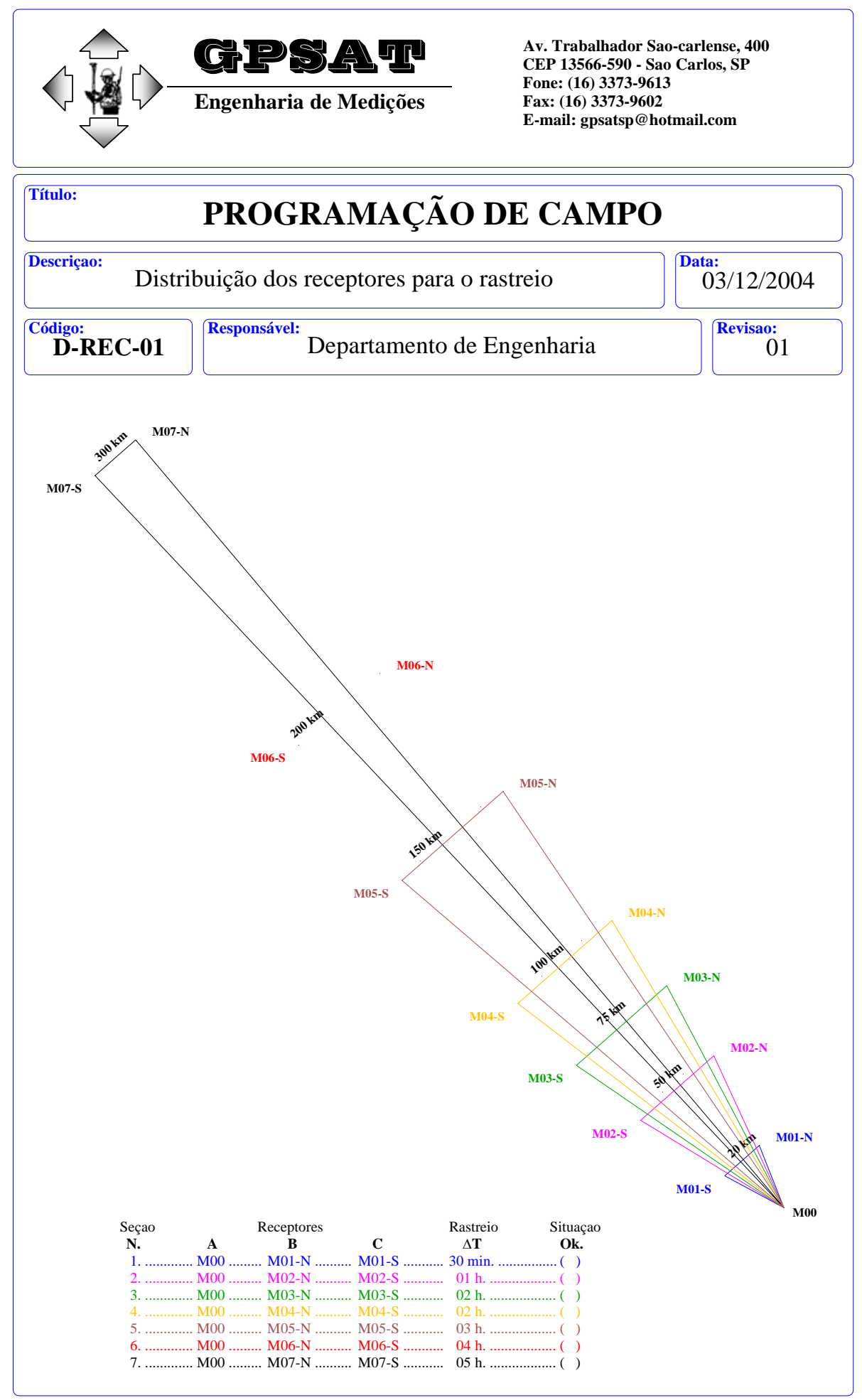

Figura 54 - Mapa de projeto MGPS-1 (Folha3) 

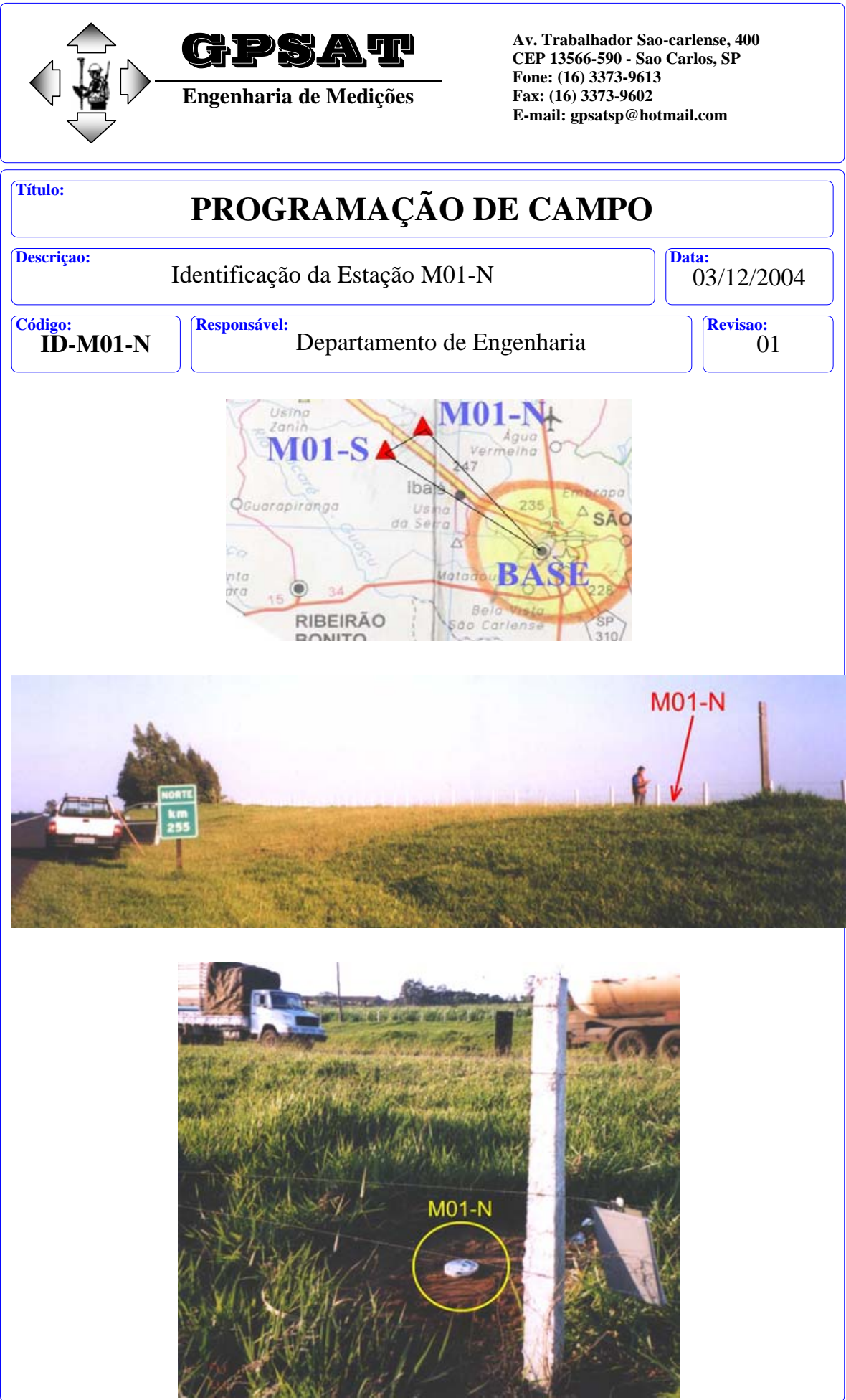

Figura 55 - Identificação da Estação M01-N (Folha4) 

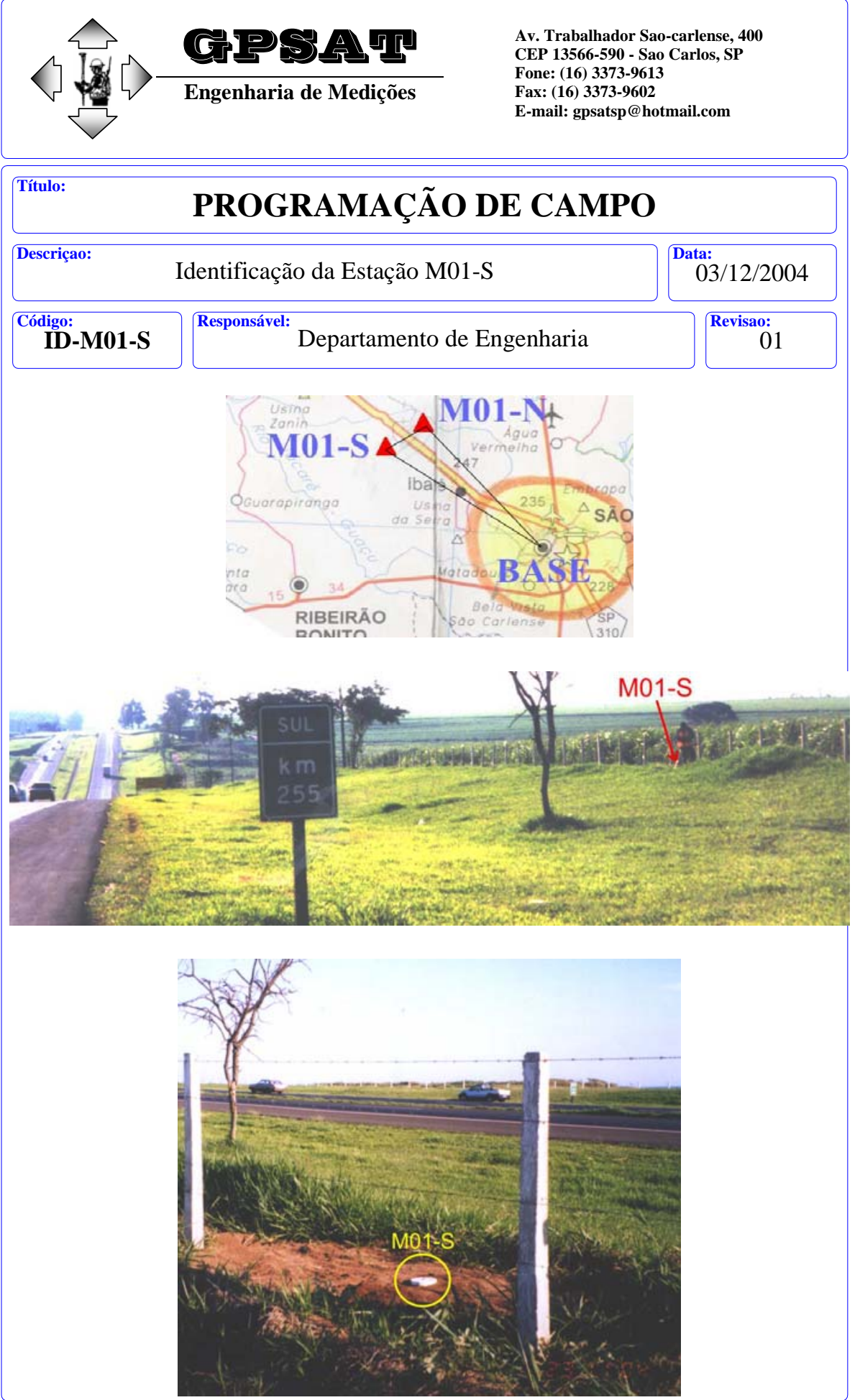

Figura 56 - Identificação da Estação M01-S (Folha5) 


\section{Levantamento de Campo}

Conforme a programação do plano de ação (definido no projeto), as equipes receberam suas instruções, conferiram os equipamentos e verificaram todos os materiais necessários e, por decisão e supervisão do líder (coordenador de campo), executaram suas missões.

Os observadores registram todas as informações de campo, exclusivamente para cada local, em uma planilha que representa o registro único das condições de campo enfrentadas ou das dificuldades submetidas no rastreio (por ex. Figuras 57 a e b).

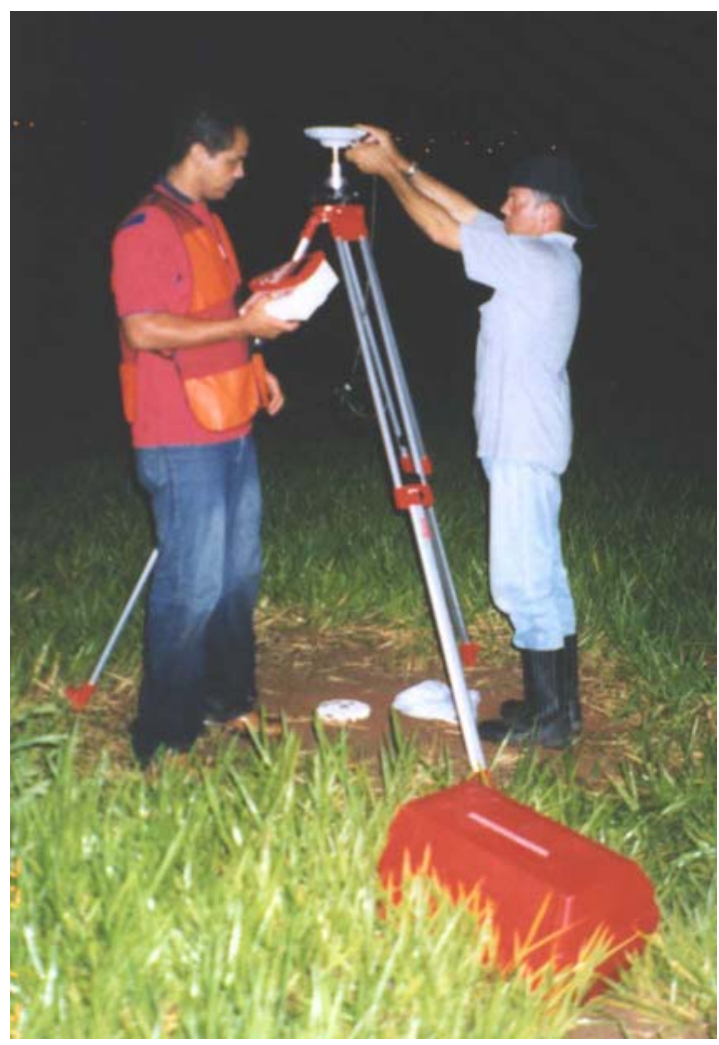

(a) Montagem do equipamento

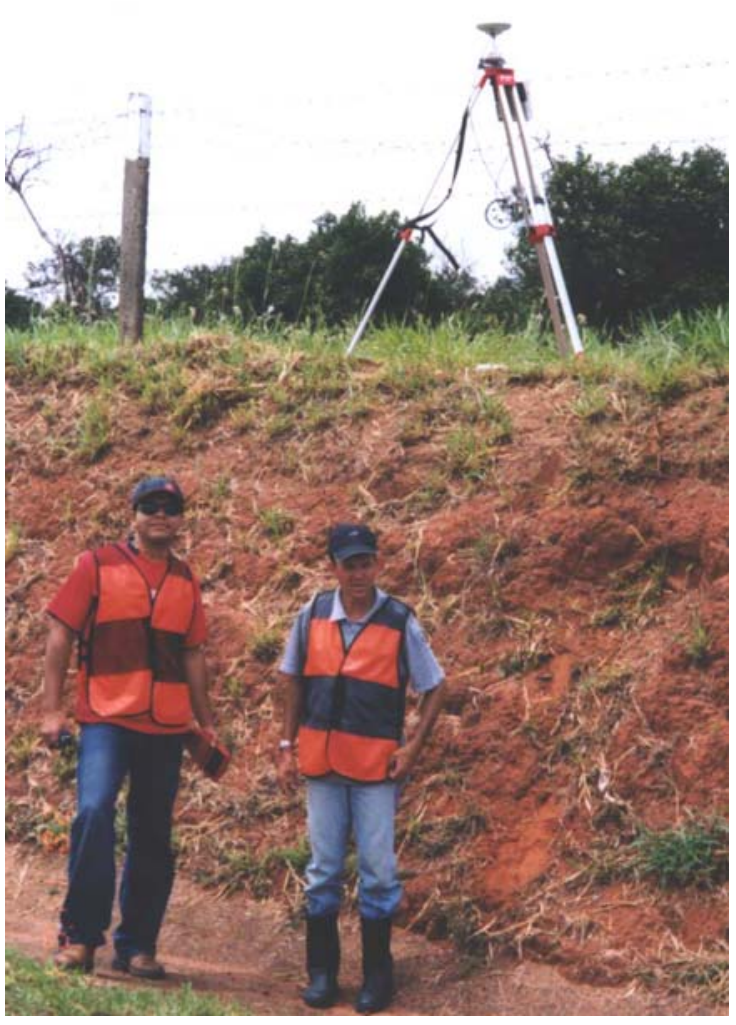

(b) Rastreio (monitoramento)

\section{Figura 57 - Rastreio de Estação}

No final da sessão, o observador assegura que os dados foram registrados, e confere a altura e a centragem da antena novamente, desliga, desconecta e acondiciona o equipamento, conforme as instruções, e finaliza a seção na folha de registro de campo. Posteriormente, essas planilhas de campo são arquivadas e digitadas no banco de dados, conforme Figuras 50 e 51. 


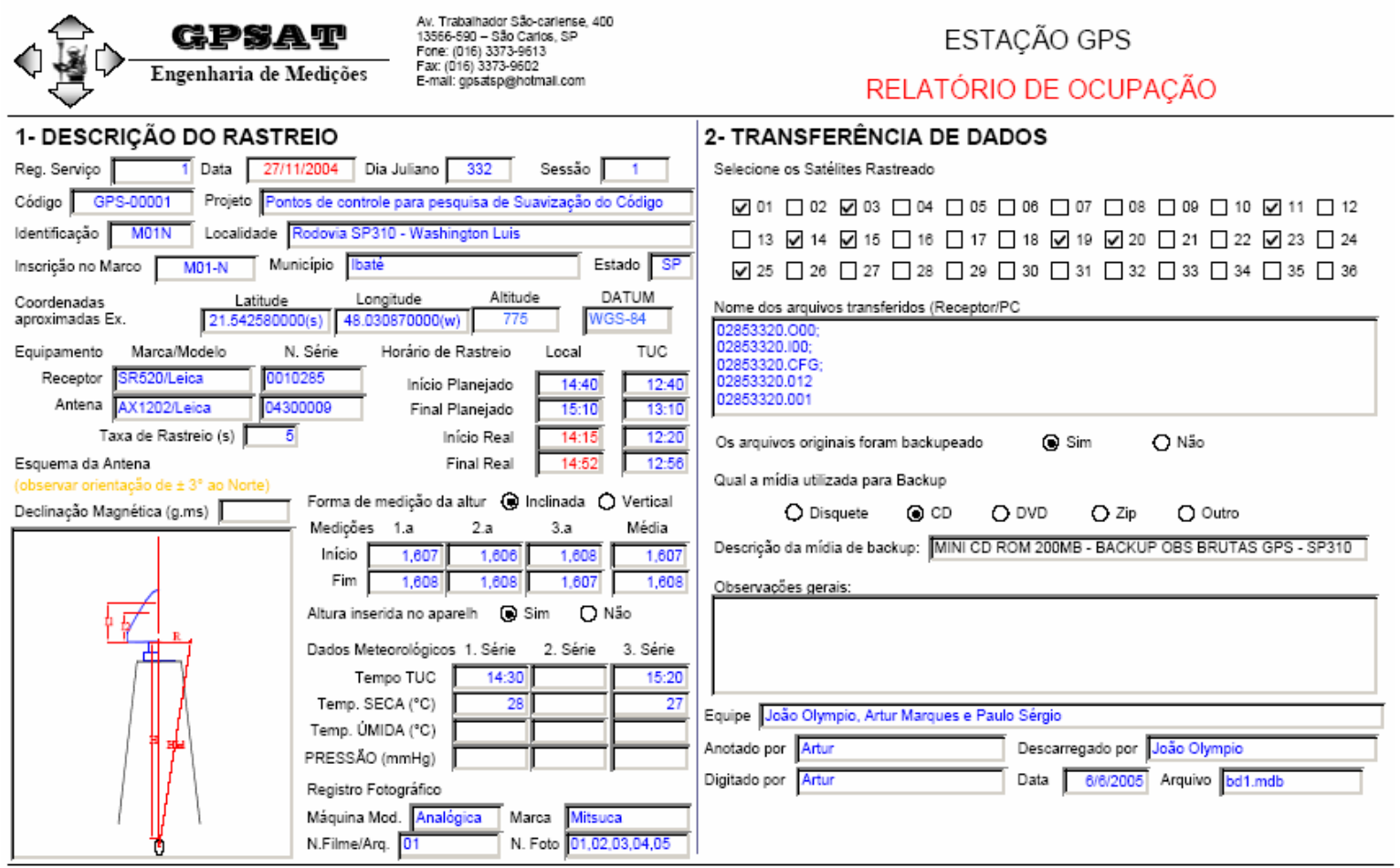

\section{Figura 58 - Relatório de ocupação M01-N}

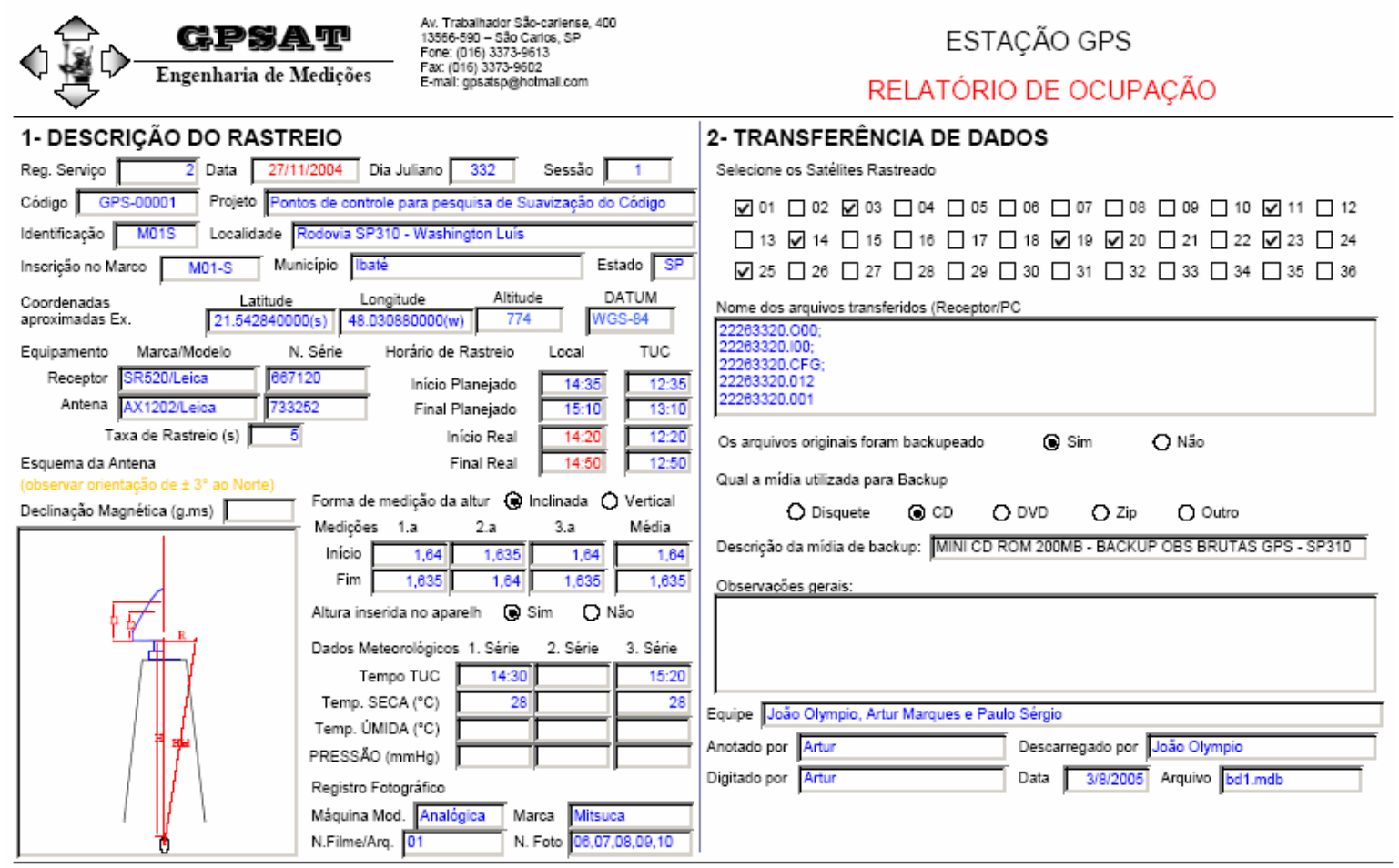

Figura 59 - Relatório de ocupação M01-S 


\section{Processamento dos dados}

Finalizada a etapa de posicionamento de campo, os dados brutos coletados que foram descarregados e armazenados em mídias normais e de backup, junto com as planilhas e informações do campo, são recebidos pelo setor de processamento e analisados novamente. Após a verificação preliminar, são inseridos no software de processamento, editados e corrigidos, quando necessário e, em seguida, processados (calculados e ajustados) para determinação das coordenadas finais dos pontos levantados.

Todo o processamento é feito em um microcomputador, por um profissional especialista que utiliza ferramentas, métodos e técnicas específicas para obter o melhor resultado possível com os dados coletados. Os procedimentos usados seguem as recomendações do fabricante do software e os padrões das normas e especificações oficiais. A seqüência adotada pelo profissional encarregado do processamento segue o padrão estabelecido pela empresa. Os procedimentos (ajustes e configurações) usados devem ser registrados em uma planilha para posterior análise.

Os resultados das coordenadas finais dos pontos dependem do resultado do processamento das linhas base e do ajustamento dessas aos controles adotados. De um modo geral o processo obedece à seguinte seqüência:

- criação de um novo arquivo de projeto;

- descarregamento e importação dos dados das linhas base;

- descarregamento dos dados das efemérides precisas (quando for o caso);

- edição dos arquivos de dados das linhas base para correções e mudanças;

- processamento de todas as linhas bases;

- revisão, inspeção e avaliação da adequação dos resultados das linhas base;

- execução de mudanças e rejeições necessárias;

- reprocessamento das linhas base e reavaliar os resultados;

- identificação das linhas base (independentes e triviais), e

- revisão do fechamento das figuras e o ajustamento de redes. 
No caso desse serviço, o software usado foi o SKI PRO 3.0 fornecido pelo mesmo fabricante do instrumento usado e o processamento de todos os pontos foi feito no mesmo padrão e com o mesmo rigor. Por se tratar de um trabalho particular, cujo conteúdo é restritivo, conforme autorizado pelo proprietário, serão apresentados apenas partes do processo que ilustram os procedimentos usados.

Os passos descritos a seguir referem-se apenas ao processamento dos pontos M01-N e M01-S da seção 01:

- Para cada ponto foram calculadas suas coordenadas, tomando como base a estação M00 conhecida como “STTU” localizada na EESC-USP (Figura 60).

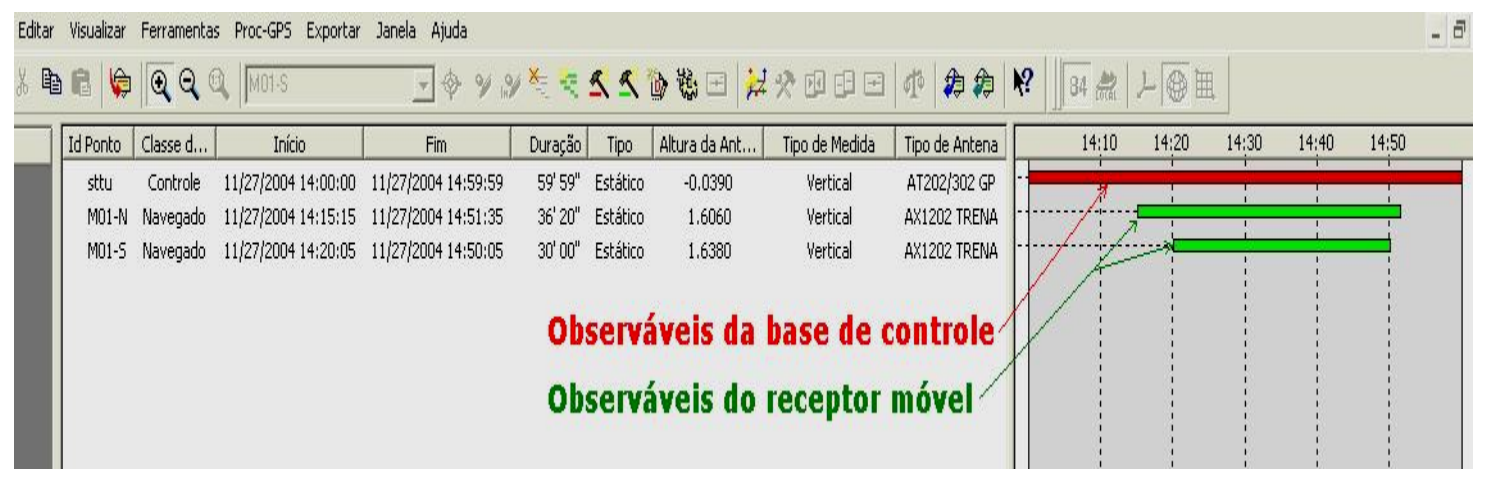

Figura 60 - Processamento da seção 01

- Verificações sobre o estado de cada satélite durante o período de rastreio (na base, e nos pontos rastreados) para detectar possíveis problemas (Figura 61).

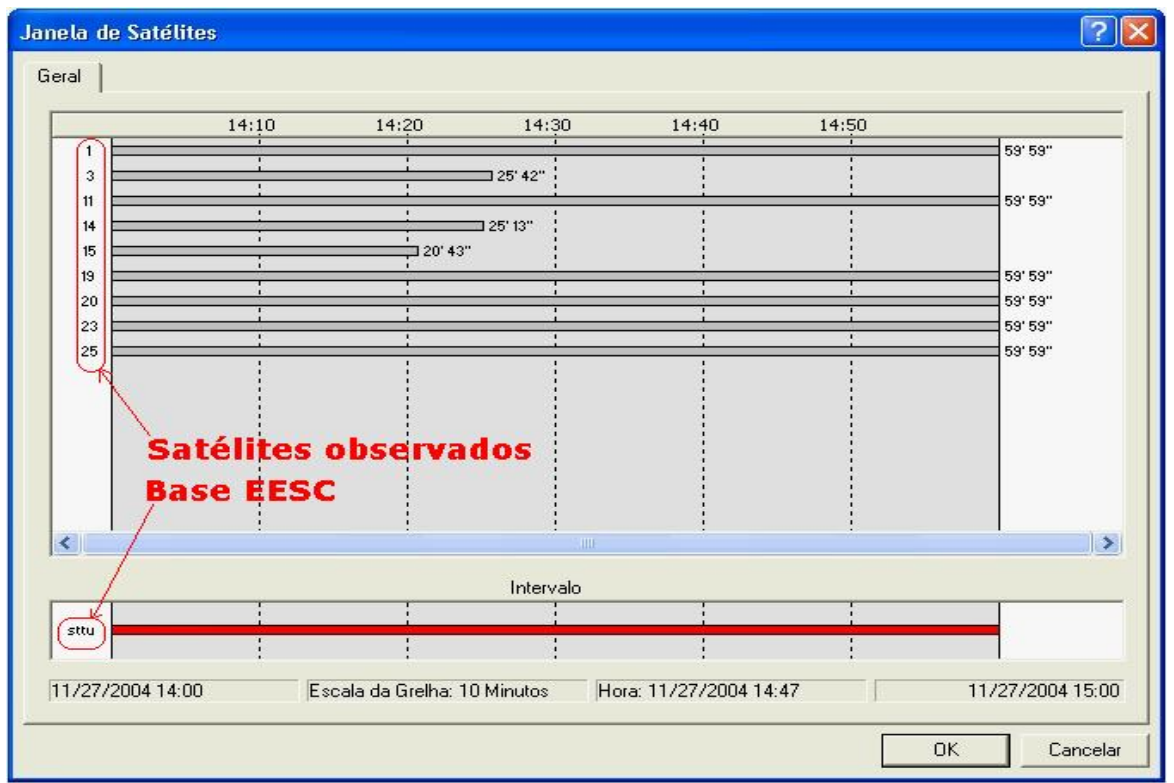

Figura 61 - Satélites observados na base de referência 
- As configurações dos parâmetros usados no pós-processamento foram (Figura 62):

- ângulo de corte dos satélites de $15^{\circ}$;

- $\quad$ as efemérides foram as transmitidas;

- opção “Automático” para os dados usados, neste caso a fase da portadora;

- uso de todos os satélites rastreados, por não apresentarem problemas.

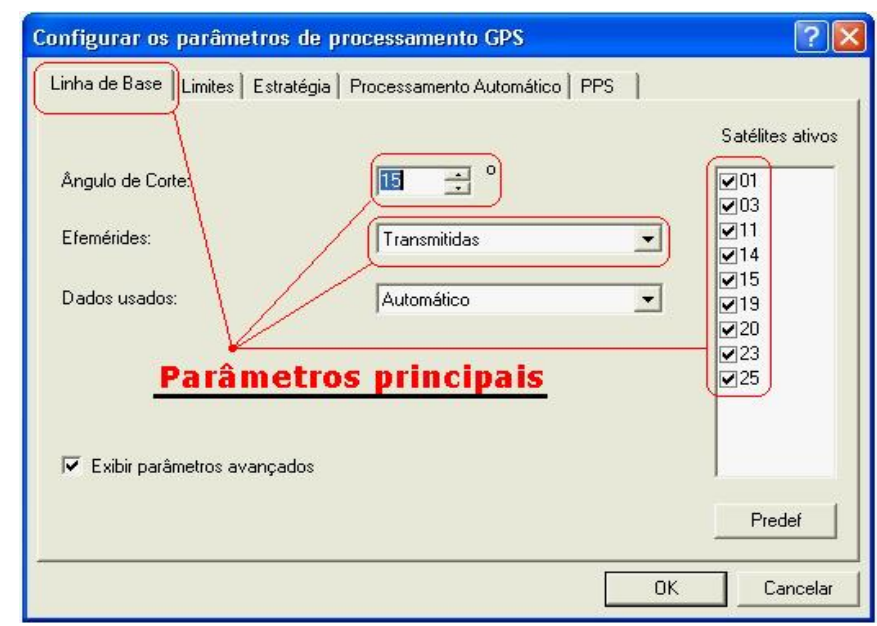

Figura 62 - Parâmetros usados no processamento

Após os procedimentos de constatação da saúde dos satélites, da configuração dos parâmetros a serem usados, da verificação dos valores de DOP e possíveis perdas de ciclo, executou-se o processamento. No primeiro instante foram calculadas as coordenadas de cada ponto da seção por vetores independentes, firmando como referência a mesma base, durante o período de rastreio (Figura 63).

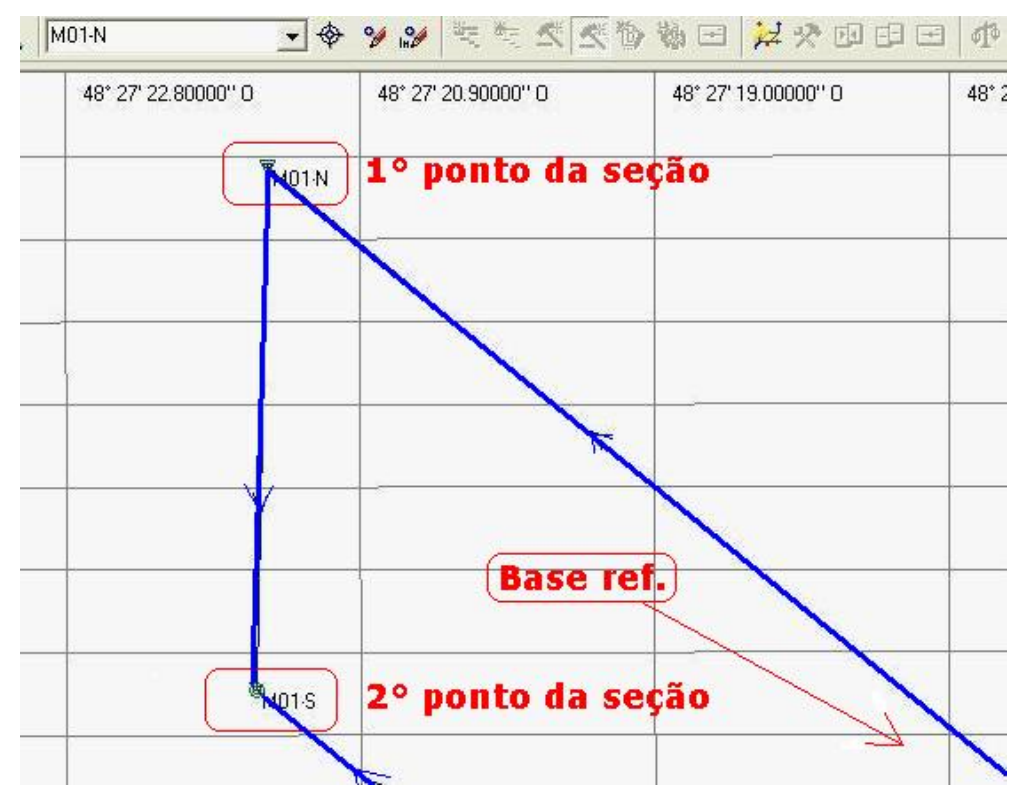

Figura 63 - Triângulo formado pelos vetores entre as estações. 
Em seguida, estabeleceu-se como referência um dos pontos rastreados e analisou-se a precisão do fechamento vetorial do triângulo formado entre os dois pontos da seção e a estação base de controle (Figura 64).

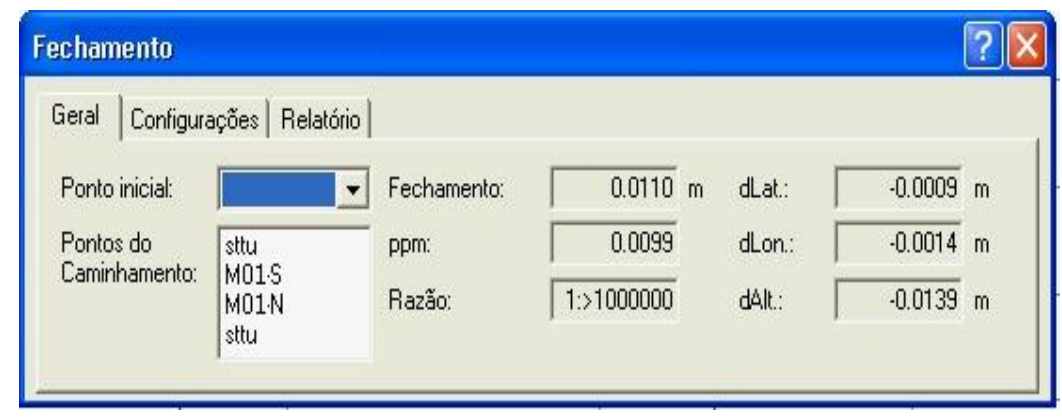

Figura 64 - Fechamento do triângulo entre as estações

E dessa forma foi feito o processamento para cada ponto de controle. Os parâmetros usados ficam registrados em um arquivo "log” no programa usado, além de serem também registrados em uma planilha especifica da empresa para cada linha de base. Um exemplo de relatório gerado pelo programa para os pontos da $1^{\text {a }}$ Seção STTU, M01-N e M01-S é mostrado a seguir.

\section{Leica \\ Resultados - Linha de base sttu - M01-N}

\section{Informações do Projeto}

Nome do projeto:

Data de criação:

Fuso horário:

Nome do sistema de coordenadas:

Aplicativo:

Processamento kernel:

Processado:
Sul 01

01/15/2005 14:15:17

$-3 \mathrm{~h} 00^{\prime}$

WGS-UTM 22

Leica SKI-Pro 3.0

PSI-Pro 1.0

01/15/2005 14:25:53

\section{Informações do Ponto}

Tipo de receptor / N/S:

Tipo de antena / N/S:

Altura da antena:

Coordenadas iniciais:

Latitude:

Longitude:

Alt. Elip.:
Referência: sttu

SR9500 / 0

AT202/302 GP / -

$-0.0390 \mathrm{~m}$

$22^{\circ} 00^{\prime} 17.80085^{\prime \prime} \mathrm{S}$

$47^{\circ} 53^{\prime} 56.99582 " \mathrm{O}$

$824.7000 \mathrm{~m}$
Remoto: M01-N

SR520 / 22223

AX1202 TRENA / -

$1.6060 \mathrm{~m}$

$21^{\circ} 54^{\prime} 25.72834 " \mathrm{~S}$

$48^{\circ} 03^{\prime} 08.62382 " \mathrm{O}$

$772.1894 \mathrm{~m}$ 


\section{Parâmetros de Processamento}

\section{Parâmetros}

Ângulo de corte:

Tipo de efemérides:

Tipo de solução:

Freqüência:

Fixar ambigüidades até:

Duração mín. p/ a solução float (estático):

Taxa de amostragem:

Modelo troposférico:

Modelo ionosférico:

Usar modelo estocástico:

Distância mín.:

Atividade ionosférica:

$\begin{array}{lll}\text { Selecionado } & \text { Usado } & \text { Comentário } \\ 15^{\circ} & 15^{\circ} & \\ \text { Transmitida } & \text { Transmitida } & \\ \text { Automático } & \text { Fase } & \\ \text { Automático } & \text { Automático } & \\ 80 \mathrm{~km} & 80 \mathrm{~km} & \\ 5^{\prime} 00^{\prime \prime} & 5^{\prime} 00^{\prime \prime} \\ \text { Usar Tudo } & 5 \\ \text { Hopfield } & \text { Hopfield } \\ \text { Automático } & \text { Calculado } \\ \text { Sim } & \text { Sim } \\ 8 \mathrm{~km} & 8 \mathrm{~km} \\ \text { Automático } & \text { Automático }\end{array}$

\section{Seleção de Satélites}

Satélites desativados manualmente:

Nenhum

\section{Estatísticas da Ambigüidade}

Número total de ambigüidades: 18

Número de ambigüidades fixadas:

Número de ambigüidades independentes:

Tempo médio entre fixadas independentes:

Porcentagem de épocas fixadas (L1):

\section{Estatísticas Gerais:}

$\begin{array}{llll}\text { Status } & \text { De } & \text { Para } & \text { Duração } \\ \text { Fixada } & 11 / 27 / 200419: 15: 15 & 11 / 27 / 200419: 51: 35 & 366^{\prime} \text { 20" }\end{array}$

\section{Coordenadas Finais}

Coordenadas:

Latitude:

Longitude:

Alt. Elip.:

ipo de solução:

reqüência:

ımbigüidade:

Qualidade:

DOPs (mín-máx):
Referência: sttu

Remoto: M01-N

$22^{\circ} 00^{\prime} 17.80085^{\prime \prime} \mathrm{S}$
$47^{\circ} 53^{\prime} 56.99582^{\prime \prime} \mathrm{O}$
$824.7000 \mathrm{~m}$

$21^{\circ} 54^{\prime} 25.72834^{\prime \prime} \mathrm{S}$

$48^{\circ} 03^{\prime} 08.62382^{\prime \prime} \mathrm{O}$

$772.1894 \mathrm{~m}$

\section{Fase}

IonoLivre (L3)

Sim

Dp. Lat: $0.0005 \mathrm{~m}$

Qld. Pos.: $0.0008 \mathrm{~m}$

GDOP: $2.0-5.8$

PDOP: $1.8-4.8$
Dp. Lon: $0.0005 \mathrm{~m} \quad$ Dp. Alt.: $0.0018 \mathrm{~m}$

Dp. Declividade: $0.0006 \mathrm{~m}$

HDOP: $0.9-1.7$ 


\section{feica \\ Resultados - Linha de base \\ sttu - M01-S}

\section{Informações do Projeto}

Nome do projeto:

Data de criação:

Fuso horário:

Nome do sistema de coordenadas:

Aplicativo:

Processamento kernel:

Processado:
Sul 01

01/15/2005 14:15:17

-3h 00'

WGS-UTM 22

Leica SKI-Pro 3.0

PSI-Pro 1.0

01/15/2005 14:25:53

\section{Informações do Ponto}

Tipo de receptor / N/S:

Tipo de antena / N/S:

Altura da antena:

Coordenadas iniciais:

Latitude:

Longitude:

Alt. Elip:
Referência: sttu

SR9500 / 0

AT202/302 GP / -

$-0.0390 \mathrm{~m}$

$22^{\circ} 00^{\prime} 17.80085^{\prime \prime} \mathrm{S}$

$47^{\circ} 53^{\prime} 56.99582 " \mathrm{O}$

$824.7000 \mathrm{~m}$
Remoto: M01-S

SR520 / 22226

AX1202 TRENA / -

$1.6380 \mathrm{~m}$

$21^{\circ} 54^{\prime} 28.45357^{\prime \prime} \mathrm{S}$

$48^{\circ} 03^{\prime} 08.81976 " \mathrm{O}$

$772.5022 \mathrm{~m}$

\section{Parâmetros de Processamento}

\section{Parâmetros}

Ângulo de corte:

Tipo de efemérides:

Tipo de solução:

Freqüência:

Fixar ambigüidades até:

Duração mín. p/ a solução float (estático):

Taxa de amostragem:

Modelo troposférico:

Modelo ionosférico:

Usar modelo estocástico:

Distância mín.:

Atividade ionosférica:

$\begin{array}{ll}\text { Selecionado } & \text { Usado } \\ 15^{\circ} & 15^{\circ} \\ \text { Transmitida } & \text { Transmitida } \\ \text { Automático } & \text { Fase } \\ \text { Automático } & \text { Automático } \\ 80 \mathrm{~km} & 80 \mathrm{~km} \\ 5^{\prime} 00^{\prime \prime} & 5^{\prime} 00^{\prime \prime} \\ \text { Usar Tudo } & 5 \\ \text { Hopfield } & \text { Hopfield } \\ \text { Automático } & \text { Calculado } \\ \text { Sim } & \text { Sim } \\ 8 \mathrm{~km} & 8 \mathrm{~km} \\ \text { Automático } & \text { Automático }\end{array}$

\section{Seleção de Satélites}

Satélites desativados manualmente:

Nenhum

\section{Estatísticas da Ambigüidade}

Número total de ambigüidades:

Número de ambigüidades fixadas:

Número de ambigüidades independentes:

Tempo médio entre fixadas independentes: 
Porcentagem de épocas fixadas (L1):

Estatísticas Gerais:

$\begin{array}{llll}\text { Status } & \text { De } & \text { Para } & \text { Duração } \\ \text { Fixada } & 11 / 27 / 200419: 20: 05 & 11 / 27 / 200419: 50: 05 & 30^{\prime} 00^{\prime \prime}\end{array}$

\section{Coordenadas Finais}

Coordenadas:

Latitude:

Longitude:

Alt. Elip.:

Tipo de solução:

Freqüência:

Ambigüidade:

Qualidade:

DOPs (mín-máx):
Referência: sttu

$$
\begin{aligned}
& 22^{\circ} 00^{\prime} 17.80085^{\prime \prime} \mathrm{S} \\
& 47^{\circ} 53^{\prime} 56.99582^{\prime \prime} \mathrm{O} \\
& 824.7000 \mathrm{~m}
\end{aligned}
$$

Fase

IonoLivre (L3)

Sim

Dp. Lat: $0.0006 \mathrm{~m}$ Qld. Pos.: $0.0008 \mathrm{~m}$

Dp. Lon: $0.0006 \mathrm{~m}$ Dp. Declividade: $0.0006 \mathrm{~m}$

$21^{\circ} 54^{\prime} 28.45384^{\prime \prime} \mathrm{S}$

$48^{\circ} 03^{\prime} 08.81985^{\prime \prime} \mathrm{O}$

$772.5049 \mathrm{~m}$

\section{Leica}

\section{Resultados - Linha de base M01-N - M01-S}

\section{Informações do Projeto}

Nome do projeto:

Data de criação:

Fuso horário:

Nome do sistema de coordenadas:

Aplicativo:

Processamento kernel:

Processado:
Sul 01

01/15/2005 14:15:17

$-3 \mathrm{~h} 00^{\prime}$

WGS-UTM 22

Leica SKI-Pro 3.0

PSI-Pro 1.0

06/26/2005 14:36:18

\section{Informações do Ponto}

Tipo de receptor / N/S:

Tipo de antena / N/S:

Altura da antena:

Coordenadas iniciais:

Latitude:

Longitude:

Alt. Elip.:
Referência: M01-N

SR520 / 22223

AX1202 TRENA / -

$1.6060 \mathrm{~m}$

$21^{\circ} 54^{\prime} 25.72834 " \mathrm{~S}$

$48^{\circ} 03^{\prime} 08.62382^{\prime \prime} \mathrm{O}$

$772.1894 \mathrm{~m}$
Remoto: M01-S

SR520 / 22226

AX1202 TRENA / -

$1.6380 \mathrm{~m}$

$21^{\circ} 54^{\prime} 28.45357^{\prime \prime} \mathrm{S}$

$48^{\circ} 03^{\prime} 08.81976 " \mathrm{O}$

$772.5022 \mathrm{~m}$ 


\section{Parâmetros de Processamento}

\section{Parâmetros}

Ângulo de corte:

Tipo de efemérides:

Tipo de solução:

Freqüência:

Fixar ambigüidades até:

Duração mín. p/ a solução float (estático):

Taxa de amostragem:

Modelo troposférico:

Modelo ionosférico:

Usar modelo estocástico:

Distância mín.:

Atividade ionosférica:

$\begin{array}{lll}\text { Selecionado } & \text { Usado } & \text { Comentário } \\ 15^{\circ} & 15^{\circ} & \\ \text { Transmitida } & \text { Transmitida } & \\ \text { Automático } & \text { Fase } & \\ \text { Automático } & \text { Automático } \\ 80 \mathrm{~km} & 80 \mathrm{~km} \\ 5^{\prime} 00^{\prime \prime} & 5^{\prime} 00^{\prime \prime} \\ \text { Usar Tudo } & 5 \\ \text { Hopfield } & \text { Hopfield } \\ \text { Automático } & \text { Klobuchar } \\ \text { Sim } & \text { Sim } \\ 8 \mathrm{~km} & 8 \mathrm{~km} \\ \text { Automático } & \text { Automático }\end{array}$

\section{Seleção de Satélites}

Satélites desativados manualmente:

Nenhum

\section{Estatísticas da Ambigüidade}

Número total de ambigüidades:

16

Número de ambigüidades fixadas: 16

Número de ambigüidades independentes: 180

Tempo médio entre fixadas independentes: $10 "$

Porcentagem de épocas fixadas (L1):

Porcentagem de épocas fixadas (L2):

Porcentagem de épocas fixadas (tudo):

Estatísticas Gerais:

$\begin{array}{llll}\text { Status } & \text { De } & \text { Para } & \text { Duração } \\ \text { Fixada } & 11 / 27 / 200419: 20: 05 & 11 / 27 / 200419: 50: 05 & 30 \text { ' 00" }\end{array}$

\section{Coordenadas Finais}

\section{Coordenadas: \\ Latitude: \\ Longitude: \\ Alt. Elip.:}

Tipo de solução:

Freqüência:

Ambigüidade:

Qualidade:

DOPs (mín-máx):

\section{Referência: M01-N}

$21^{\circ} 54^{\prime} 25.72834^{\prime \prime} \mathrm{S}$

$48^{\circ} 03^{\prime} 08.62382^{\prime \prime} \mathrm{O}$

$772.1894 \mathrm{~m}$

Fase

L1 e L2

Sim
Remoto: M01-S

$21^{\circ} 54^{\prime} 28.45356 " \mathrm{~S}$

$48^{\circ} 03^{\prime} 08.81976 " \mathrm{O}$

$772.5021 \mathrm{~m}$
Dp. Lat: $0.0001 \mathrm{~m}$ Qld. Pos.: $0.0002 \mathrm{~m}$

GDOP: $2.1-5.8$

PDOP: $1.9-4.8$
Dp. Lon: $0.0001 \mathrm{~m} \quad$ Dp. Alt.: $0.0004 \mathrm{~m}$

Dp. Declividade: $0.0001 \mathrm{~m}$

HDOP: $1.0-1.7 \quad$ VDOP: $1.6-4.5$

Considerando o ajustamento dos pontos com restrições mínimas, conforme solicitado pelo cliente, os resultados do programa para a $1^{\text {a }}$ seção são mostrados a seguir. 


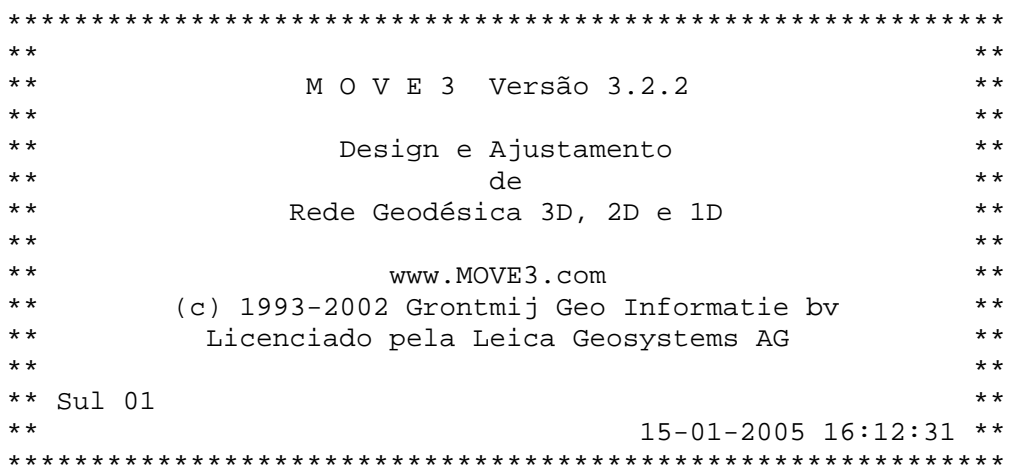

3D rede com restrições mínimas no WGS 84 elipsóide

\section{ESTAÇÕES}

Número de estações conhecidas (em parte) 1 Número de estações desconhecidas

$\begin{array}{ll} & 1 \\ \text { Total } & 2 \\ & 3\end{array}$

OBSERVAÇõES

Diferenças de coordenadas GPS Coordenadas desconhecidas

$\begin{array}{rr} & 9 \\ 3 & (3 \text { linhas de base }) \\ \text { Total } \quad 12\end{array}$

INCÓGNITAS

Coordenadas

$\begin{array}{ll}9 \\ \text { Total } & 9\end{array}$

Graus de liberdade

AJUSTAMENTO

Número de iterações

Correção máxima na última iteração

$0.0000 \mathrm{~m}$

\section{TESTES}

$\begin{array}{ll}\text { Alfa (multidimensional) } & 0.1291 \\ \text { Alfa } \odot \text { (uma dimensão) } & 0.0500 \\ \text { Beta } & 0.80 \\ \text { Valor crítico do teste W } & 1.96 \\ \text { Valor crítico do teste F (3 dimensões) } & 1.89 \\ \text { Valor crítico do teste F (2 dimensões) } & 2.42 \\ \text { Valor crítico do teste F } & 1.89 \\ & \\ \text { Teste F } & 0.121 \text { aceito }\end{array}$

Resultados baseados no fator da variância a-posteriori

CONSTANTES DO ELIPSÓIDE

$\begin{array}{lc}\text { Elipsóide } & \text { WGS } 84 \\ \text { Semi-eixo maior } & 6378137.0000 \mathrm{~m} \\ \text { Achatamento } & 298.257223563\end{array}$

COORDENADAS (REDE COM RESTRIÇÕES MINIMAS)

$\begin{array}{cl}\text { Estação } & \\ \text { M01-N } & \begin{array}{l}\text { Latitude } \\ \text { Longitude }\end{array} \\ \text { Altitude } \\ \text { M01-S } & \begin{array}{l}\text { Latitude } \\ \text { Longitude }\end{array} \\ \text { sttu } & \begin{array}{l}\text { Altitude } \\ \text { Latitude } \\ \text { Longitude } \\ \text { Altitude }\end{array}\end{array}$

Coordenadas

Corr

$\mathrm{Dp}$

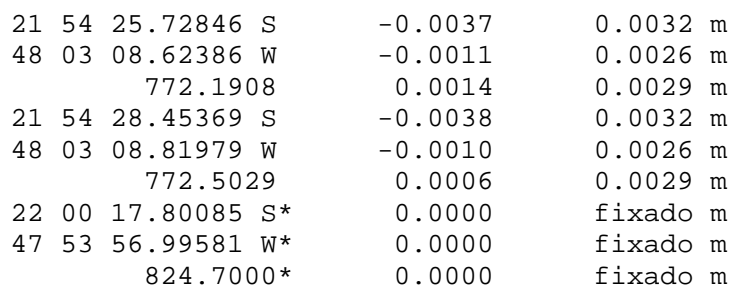


ELIPSES DE ERROS ABSOLUTOS

$\begin{array}{rrccccc}\text { Estação } & \text { A } & \text { B } & \text { A/B } & \text { Phi } & \text { Dp Alt } \\ \text { M01-N } & 0.0039 & 0.0014 \mathrm{~m} & 2.9 & 38 \text { graus } & 0.0029 \mathrm{~m} \\ \text { M01-S } & 0.0039 & 0.0014 \mathrm{~m} & 2.9 & 38 \text { graus } & 0.0029 \mathrm{~m} \\ \text { sttu } & 0.0000 & 0.0000 \mathrm{~m} & 0.0 & 90 \text { graus } & 0.0000 \mathrm{~m}\end{array}$

OBSERVAÇÕES AJUSTADAS

$\begin{array}{lrrrrrr} & \text { Estação } & \text { Alvo } & \text { Obs Ajd } & \text { Resíduos Res. (ENH) } & \text { Dp } \\ \text { DX } & \text { sttu } & \text { M01-S } & -9105.8904 & -0.0011 & -0.0016 & 0.0014 \mathrm{~m} \\ \text { DY } & & & -13549.8360 & -0.0011 & -0.0048 & 0.0029 \mathrm{~m} \\ \text { DZ } & & 9986.7026 & -0.0052 & 0.0020 & 0.0039 \mathrm{~m} \\ \text { DX } & \text { sttu } & \text { M01-N } & -9080.9923 & 0.0009 & 0.0011 & 0.0014 \mathrm{~m} \\ \text { DY } & & & -13569.1248 & 0.0007 & 0.0037 & 0.0029 \mathrm{~m} \\ \text { DZ } & & & 10064.5980 & 0.0040 & -0.0014 & 0.0039 \mathrm{~m} \\ \text { DX } & \text { M01-N } & \text { M01-S } & -24.8980 & 0.0003 & -0.0001 & 0.0007 \mathrm{~m} \\ \text { DY } & & & 19.2888 & -0.0005 & 0.0001 & 0.0011 \mathrm{~m} \\ \text { DZ } & & & -77.8954 & -0.0001 & 0.0006 & 0.0005 \mathrm{~m}\end{array}$

RESIDUOS DO VETOR DA LINHA DE BASE GPS

$\begin{array}{lrrrrr} & \text { Estação } & \text { Alvo } & \text { Vetor Ajd } & \text { Resíduos } & \text { Resíduos ppm } \\ \text { DV } & \text { sttu } & \text { M01-S } & 19137.6467 & 0.0055 \mathrm{~m} & 0.3 \mathrm{ppm} \\ \text { DV } & \text { sttu } & \text { M01-N } & 19180.2425 & 0.0042 \mathrm{~m} & 0.2 \mathrm{ppm} \\ \text { DV } & \text { M01-N } & \text { M01-S } & 84.0218 & 0.0006 \mathrm{~m} & 6.9 \mathrm{ppm}\end{array}$

TESTE DAS OBSERVAÇÕES

$\begin{array}{lrrrrrrr} & \text { Estação } & \text { Alvo } & \text { MDB } & \text { Red } & \text { BNR } & \text { teste W } & \text { teste T } \\ & & & & & & & \\ \text { DX } & \text { sttu } & \text { M01-S } & 0.0067 \mathrm{~m} & 47 & 3.1 & -0.34 & 1.00 \\ \text { DY } & & 0.0095 \mathrm{~m} & 48 & 2.9 & 1.27 & \\ \text { DZ } & & 0.0122 \mathrm{~m} & 57 & 2.6 & -1.52 & \\ \text { DX } & \text { sttu } & \text { M01-N } & 0.0067 \mathrm{~m} & 40 & 3.5 & 0.34 & 1.00 \\ \text { DY } & & & 0.0095 \mathrm{~m} & 41 & 3.4 & -1.27 & \\ \text { DZ } & & 0.0122 \mathrm{~m} & 43 & 3.2 & 1.52 & \\ \text { DX } & \text { M01-N } & \text { M01-S } & 0.0067 \mathrm{~m} & 12 & 16.5 & 0.34 & 1.00 \\ \text { DY } & & 0.0095 \mathrm{~m} & 11 & 17.9 & -1.27 & \\ \text { DZ } & & 0.0122 \mathrm{~m} & -0 & 32.2 & 1.52 & \\ & & & & & & & \end{array}$

\section{Relatório Final}

O relatório final, independente da finalidade, deve apresentar uma descrição sucinta das ações efetuadas para execução do serviço prestado, os resultados das coordenadas dos pontos levantados e suas precisões, considerando as exigências normativas e as solicitadas pelo cliente. Junto com o relatório também deve seguir uma mídia contendo os dados brutos e processados. Como relatório deste serviço, tem-se toda a descrição apresentada anteriormente, pois engloba todos os aspectos necessários para o entendimento do serviço. A título de exemplo padrão de relatório é apresentado a seguir um resumo, para não ficar muito repetitivo. 


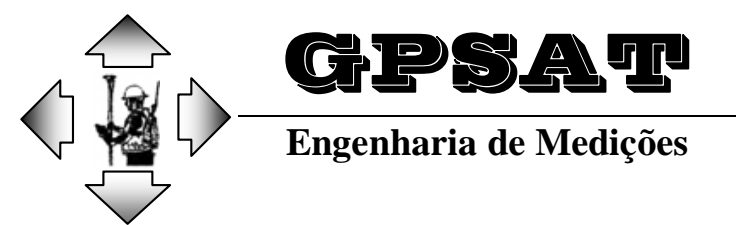

Av. Trabalhador Sao-carlense, 400

CEP 13566-590 - Sao Carlos, SP

Fone: (16) 3373-9613

Fax: (16) 3373-9602

E-mail: gpsatsp@hotmail.com

Título:

RELATÓRIO TÉCNICO DE SERVIÇO COM GPS

\section{POSICIONAMENTO DE PONTOS DE CONTROLE}




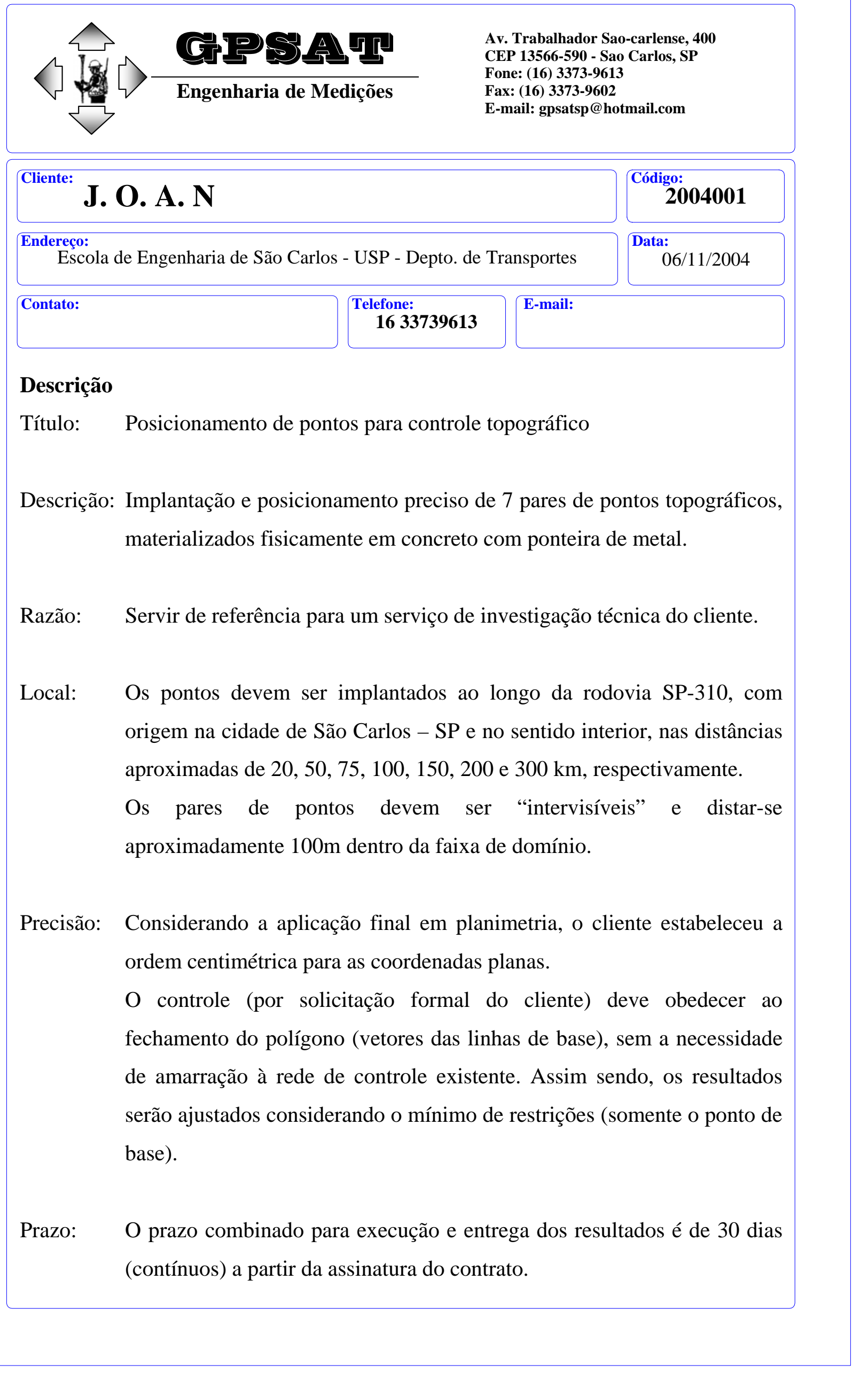




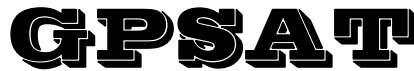

Engenharia de Medições
Av. Trabalhador Sao-carlense, 400

CEP 13566-590 - Sao Carlos, SP

Fone: (16) 3373-9613

Fax: (16) 3373-9602

E-mail: gpsatsp@hotmail.com

\section{Projeto}

O projeto foi planejado considerando o pedido do cliente, a prática e experiência profissional da equipe técnica responsável pelo serviço, seguindo as exigências e recomendações das especificações oficiais vigentes de posicionamento com GPS. (IBGE, 1992).

O método de posicionamento empregado foi o relativo estático, com o uso de 3 (três) receptores geodésicos (L1/L2) da marca Leica Geosystems, modelo SR520, sendo 1 de base fixa colocado no ponto geodésico denominado STTU e os outros dois remotos usados em cada par de pontos.

O tempo de ocupação dos pontos foi definido em função da necessidade de precisão e as recomendações mínimas estabelecidas pelas especificações oficiais, conforme o comprimento da linha de base, sendo:

\begin{tabular}{c|c|c}
\hline Ptos & L.B. Aprox. & Tempo \\
\hline M01 & $20 \mathrm{~km}$ & $1 \mathrm{~h}$ \\
\hline M02 & $50 \mathrm{~km}$ & $1 \mathrm{~h}$ \\
\hline M03 & $75 \mathrm{~km}$ & $2 \mathrm{~h}$ \\
\hline M04 & $100 \mathrm{~km}$ & $2 \mathrm{~h}$ \\
\hline
\end{tabular}

\begin{tabular}{c|c|c}
\hline Ptos & L.B. Aprox. & Tempo \\
\hline M05 & $150 \mathrm{~km}$ & $3 \mathrm{~h}$ \\
\hline M06 & $200 \mathrm{~km}$ & $4 \mathrm{~h}$ \\
\hline M07 & $300 \mathrm{~km}$ & $5 \mathrm{~h}$ \\
\hline
\end{tabular}

No rastreamento foram usadas três equipes compostas por um técnico especializado em cada receptor.

O processamento dos dados foi feito usando o software proprietário que acompanha o equipamento, no caso o SKI-PRO versão 3.0. As linhas de base foram processadas com os seguintes parâmetros e configurações iniciais:

- máscara de elevação: $\quad 15^{\circ}$

- taxa de amostragem: 5”

- efemérides: Transmitidas

- model. Ionosférico: Automático

- model. Troposférico: Hopfild 


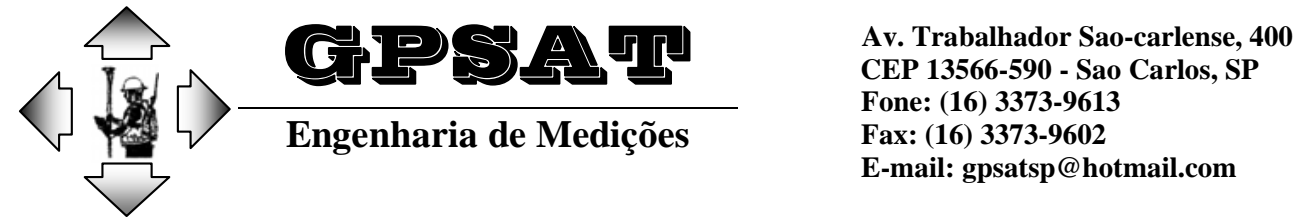

Considerando os resultados obtidos no processamento dos vetores das linhas de base entre o STTU e os pontos levantados e também entre eles, o erro de fechamento das figuras (em metros), conforme solicitado pelo cliente, é mostrado na tabela abaixo:

\begin{tabular}{l|l|l|l|l|l|l|l}
\hline STTU & M01-N & M02-N & M03-N & M04-N & M05-N & M06-N & M07-N \\
\hline M01-S & 0,0080 & & & & & & \\
\hline M02-S & & 0,0130 & & & & & \\
\hline M03-S & & & 0,0020 & & & & \\
\hline M04-S & & & & 0,0075 & & & \\
\hline M05-S & & & & & 0,0072 & & \\
\hline M06-S & & & & & & 0,0441 & \\
\hline M07-S & & & & & & & 0,0414 \\
\hline
\end{tabular}

Com o resultado das linhas de base obtido procedeu-se ao ajustamento (restrições mínimas) para obtenção das coordenadas dos pontos. O resultado das coordenadas geodésicas é apresentado na tabela a seguir, com suas respectivas precisões.

Datum de referência: WGS-84 (SIRGAS 2000) Oficial do Brasil.

\begin{tabular}{|c|c|c|c|}
\hline Estação & Coordenada & Valor & Dp (m) \\
\hline \multirow{3}{*}{ M01-N } & Latitude & $21^{\circ} 54^{\prime} 25.72844^{\prime \prime} \mathrm{S}$ & 0,0023 \\
\hline & Longitude & $48^{\circ} 03^{\prime} 08.62384 ” \mathrm{~W}$ & 0,0023 \\
\hline & Altitude & $772,1906 \mathrm{~m}$ & 0,0077 \\
\hline \multirow{3}{*}{ M01-S } & Latitude & $21^{\circ} 54^{\prime} 28.45372^{\prime \prime} \mathrm{S}$ & 0,0023 \\
\hline & Longitude & $48^{\circ} 03^{\prime}$ 08.81980” W & 0,0023 \\
\hline & Altitude & $772,5032 \mathrm{~m}$ & 0,0078 \\
\hline \multirow{3}{*}{ M02-N } & Latitude & $21^{\circ} 43^{\prime} 24.48663 ” \mathrm{~S}$ & 0,0018 \\
\hline & Longitude & $48^{\circ} 17^{\prime} 50.31492^{\prime \prime} \mathrm{W}$ & 0,0017 \\
\hline & Altitude & $615,0227 \mathrm{~m}$ & 0,0045 \\
\hline \multirow{3}{*}{ M02-S } & Latitude & $21^{\circ} 43^{\prime} 27.10354^{\prime \prime} \mathrm{S}$ & 0,0018 \\
\hline & Longitude & $48^{\circ} 17^{\prime} 53.72353^{\prime \prime} \mathrm{W}$ & 0,0017 \\
\hline & Altitude & $624,9241 \mathrm{~m}$ & 0,0045 \\
\hline \multirow{3}{*}{ M03-N } & Latitude & $21^{\circ} 34^{\prime} 34.55949^{\prime \prime} \mathrm{S}$ & 0,0004 \\
\hline & Longitude & $48^{\circ} 27^{\prime} 21.49422^{\prime \prime} \mathrm{W}$ & 0,0004 \\
\hline & Altitude & $553,4628 \mathrm{~m}$ & 0,0017 \\
\hline \multirow{3}{*}{ M03-S } & Latitude & $21^{\circ} 34^{\prime} 44.22197^{\prime \prime} \mathrm{S}$ & 0,0004 \\
\hline & Longitude & $48^{\circ} 27^{\prime} 21.45493 ” \mathrm{~W}$ & 0,0004 \\
\hline & Altitude & $551,9693 \mathrm{~m}$ & 0,0017 \\
\hline \multirow{3}{*}{ M04-N } & Latitude & $21^{\circ} 24^{\prime} 20.54062^{\prime \prime} \mathrm{S}$ & 0,0010 \\
\hline & Longitude & $48^{\circ} 41^{\prime} 56.21619^{\prime \prime} \mathrm{W}$ & 0,0011 \\
\hline & Altitude & $505,3872 \mathrm{~m}$ & 0,0029 \\
\hline \multirow{3}{*}{ M04-S } & Latitude & $21^{\circ} 24^{\prime} 24.06833^{\prime \prime} \mathrm{S}$ & 0,0010 \\
\hline & Longitude & $48^{\circ} 41^{\prime} 55.28051^{\prime \prime} \mathrm{W}$ & 0,0011 \\
\hline & Altitude & $504,5222 \mathrm{~m}$ & 0,0029 \\
\hline
\end{tabular}




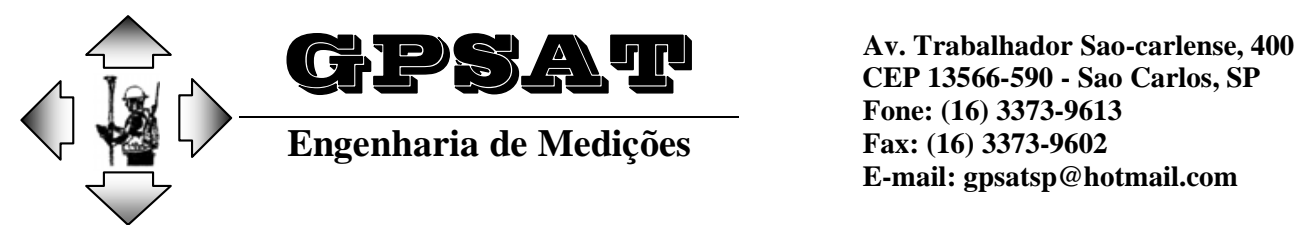

\begin{tabular}{|c|c|c|c|}
\hline Estação & Coordenada & Valor & Dp (m) \\
\hline \multirow{3}{*}{ M05-N } & Latitude & $21^{\circ} 07^{\prime} 20.77226^{\prime \prime} \mathrm{S}$ & 0,0011 \\
\hline & Longitude & $49^{\circ} 02^{\prime} 04.14806^{\prime \prime} \mathrm{W}$ & 0,0007 \\
\hline & Altitude & $525,1215 \mathrm{~m}$ & 0,0024 \\
\hline \multirow{3}{*}{ M05-S } & Latitude & $21^{\circ} 07^{\prime} 23.14090 ” \mathrm{~S}$ & 0,0011 \\
\hline & Longitude & $49^{\circ} 02^{\prime} 08.47539^{\prime \prime} \mathrm{W}$ & 0,0007 \\
\hline & Altitude & $528,7627 \mathrm{~m}$ & 0,0024 \\
\hline \multirow{3}{*}{ M06-N } & Latitude & $20^{\circ} 48^{\prime} 53.00973 ” \mathrm{~S}$ & 0,0057 \\
\hline & Longitude & $49^{\circ} 27^{\prime} 57.21737^{\prime \prime} \mathrm{W}$ & 0,0188 \\
\hline & Altitude & $515,9560 \mathrm{~m}$ & 0,0182 \\
\hline \multirow{3}{*}{ M06-S } & Latitude & $20^{\circ} 48^{\prime} 55.48580^{\prime \prime} \mathrm{S}$ & 0,0060 \\
\hline & Longitude & $49^{\circ} 27^{\prime} 56.28670^{\prime \prime} \mathrm{W}$ & 0,0190 \\
\hline & Altitude & $520,3680 \mathrm{~m}$ & 0,0183 \\
\hline \multirow{3}{*}{ M07-N } & Latitude & $20^{\circ} 38^{\prime} 48.11900^{\prime \prime} \mathrm{S}$ & 0,0009 \\
\hline & Longitude & $50^{\circ} 23^{\prime} 57.56925 ” \mathrm{~W}$ & 0,0030 \\
\hline & Altitude & $459,2780 \mathrm{~m}$ & 0,0025 \\
\hline \multirow{3}{*}{ M07-S } & Latitude & $20^{\circ} 38^{\prime} 49.74500^{\prime \prime} \mathrm{S}$ & 0,0009 \\
\hline & Longitude & $50^{\circ} 23^{\prime} 58.42016^{\prime \prime} \mathrm{W}$ & 0,0030 \\
\hline & Altitude & $459,7479 \mathrm{~m}$ & 0,0025 \\
\hline
\end{tabular}

Conclusão:

O projeto foi executado conforme as recomendações e exigências constantes no pedido do cliente. O padrão técnico de qualidade adotado pela empresa GPSAT garante total transparência na execução dos serviços e um rígido controle sobre todos os procedimentos efetuados.

Apresenta-se como recomendação, para o futuro, que alguns dos pontos sejam reocupados e ajustados à rede oficial (com a máximo de injunções) com vistas à homologação.

Agradecemos sua preferência e colocamo-nos a seu inteiro dispor para qualquer duvida ou esclarecimento. Sua satisfação é muito importante para a Equipe GPSAT.

Eng. Xxxx Xxxxxx - CREA XXXXX

Diretor Presidente

Qualquer reclamação, favor entrar em contato pessoalmente, por telefone, e-mail ou carta, que nossa equipe de atendimento procurará resolvê-la o mais breve possível. Sua satisfação é a meta de nossa empresa. 